\title{
6. SITE 357: RIO GRANDE RISE
}

\author{
The Shipboard Scientific Party ${ }^{1}$
}

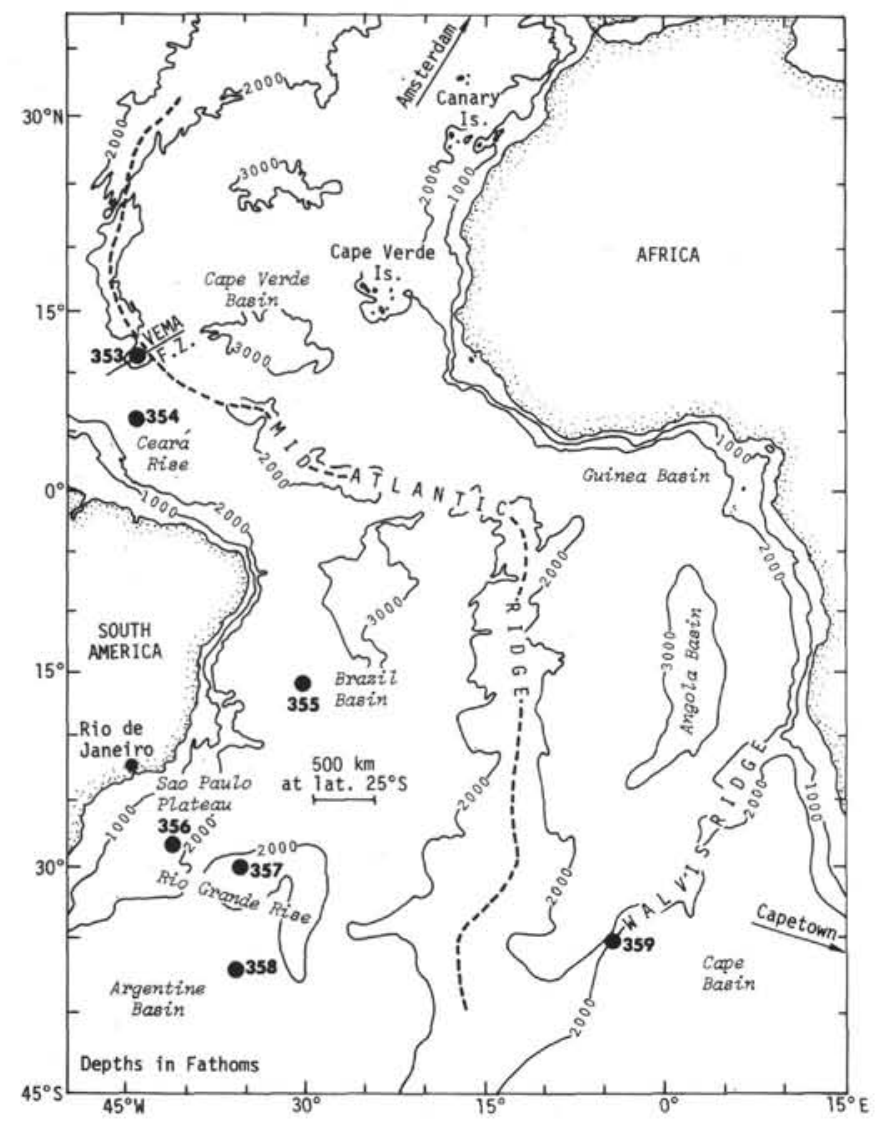

\section{SITE DATA}

Date Occupied: 23 November 74 (0821Z)

Date Departed: 28 November 74 (0527Z)

Time on Site: 4 days, 21 hours

Position: $30^{\circ} 00.25^{\prime} \mathrm{S}, 35^{\circ} 33.59^{\prime} \mathrm{W}$

Accepted Water Depth: 2086 meters (corrected, echo sounding)

Penetration: 796.5 meters

'K. Perch-Nielsen, Eidg. Technische Hochschule, Zürich, Switzerland (Co-chief scientist); P.R. Supko, Scripps Institution of Oceanography, La Jolla, California (Co-chief scientist); A. Boersma, Lamont-Doherty Geological Observatory, Palisades, New York; RL. Carlson, University of Washington, Seattle, Washington; M.G. Dinkelman, The Florida State University, Tallahassee, Florida; R.V. Fodor, University of New Mexico, Albuquerque, New Mexico; N. Kumar, Lamont-Doherty Geological Observatory, Palisades, New York; F. McCoy, Lamont-Doherty Geological Observatory, Palisades, New York; J. Thiede, Oregon State University, Corvallis, Oregon; H. B. Zimmerman, Union College, Schenectady, New York.
Number of Holes: 1

Number of Cores: 51

Total Length of Cored Section: 473.0 meters

Total Core Recovered: 345.2 meters

Principal Results: We cored a 797-meter sedimentary section on the northern flank of the Rio Grande Rise, in a water depth of 2086 meters. Most of the section is pelagic calcareous biogenic oozes, chalks, and limestone; siliceous components are important only in the lower to middle Eocene. Terrigenous components occur sporadically in the upper section, and form an important part of the Santonian to upper Campanian sediments of the lowest 125 meters. Alternate oxidizing and reducing conditions prevailed during deposition of this lowest sediment sequence; the trend through time was toward diminution of reducing conditions, until open marine conditions were reached at the end of the Campanian. The overlying section consists of marine carbonates, with a 15-meterthick deposit of allochthonous volcanic breccia, containing shallow water indicators, in the middle Eocene.

Hiatuses may be present in the Campanian and across the Cretaceous/Tertiary boundary; an important hiatus includes most of the upper Paleocene and lower Eocene.

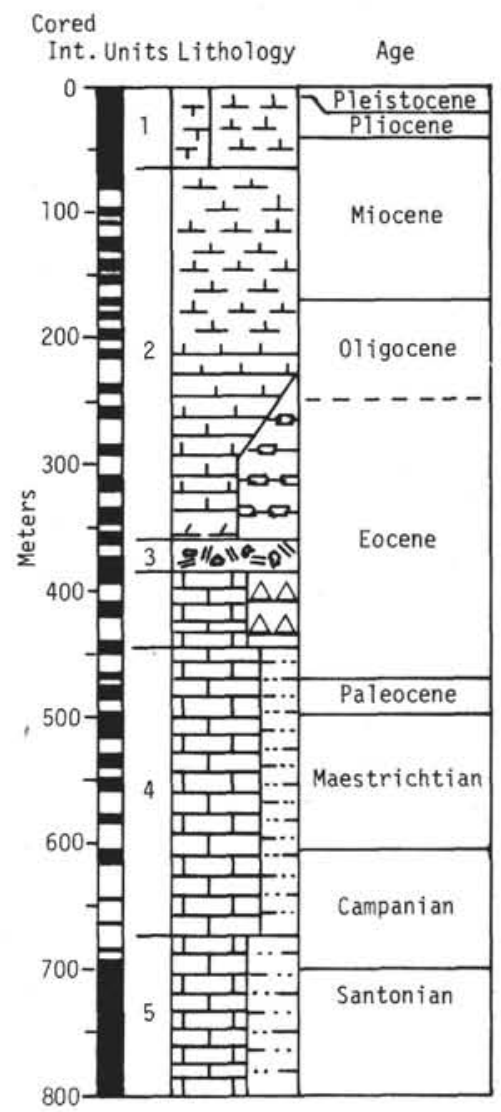


On the basis of all these indications, we favor an interpretation of this site's history whereby the deposition site subsided below an oxygen-minimum layer in the late Campanian, at the same time that the main platform of the rise subsided below sea level, allowing free surface-water exchange in this area between the north and south portions of the South Atlantic. The shallowest portions of the rise in this area would have been submerged in the Eocene and may have been the source for the volcanic breccia.

\section{BACKGROUND AND OBJECTIVES}

The Rio Grande Rise is one of the major structural highs in the South Atlantic Ocean whose strike does not parallel the magnetic anomalies of the normal ocean basement and the Mid-Atlantic Ridge, but more nearly parallels the transform faults in some parts. In other areas it is oblique to both main structural directions. In position and shape-and thus perhaps in geological framework-it resembles the Walvis Ridge, its counterpart on the eastern side of the South Atlantic (Figure 1). Both ridges have been explained as the result of a "hot spot" (Wilson, 1965; Morgan, 1971), or as being related to major fracture zones associated with South Atlantic rifting (Francheteau and Le Pichon, 1972). Although no clear patterns of magnetic anomalies have been found on the Rio Grande Rise proper, anomaly 34 has been mapped in the basins north and south of it (Ladd, 1974).

The Rio Grande Rise, like the Walvis Ridge, is largely sediment covered; as a result, knowledge about its basement is scant. Basement may consist entirely of basaltic rocks, such as those dredged from the tops of both ridges (Francheteau and Le Pichon, 1972). Geophysical data on the western part of the Rio Grande Rise suggest, however, a largely continental rise type of crust (Leyden et al., 1971). Other rock types dredged are Tertiary and Cretaceous (?) shallow water limestones, and massive (several decimeters thick) manganese crusts (M. Melguen, COB-CNEXO, Brest, personal communication). The flanks of the Rio Grande Rise are covered largely by Quaternary pelagic calcareous oozes, but piston coring at several locations has recovered Tertiary sediments (Melguen and Thiede, 1974; Le Pichon et al., 1966; Johnson, 1974).

Attempts to drill and core Rio Grande Rise sediments and basement have been carried out twice on DSDP Leg 3, at Sites 21 and 22 (Maxwell, Von Herzen, et al., 1970), see Figure 2. Spotty core control and low penetration (owing to technical difficulties) have

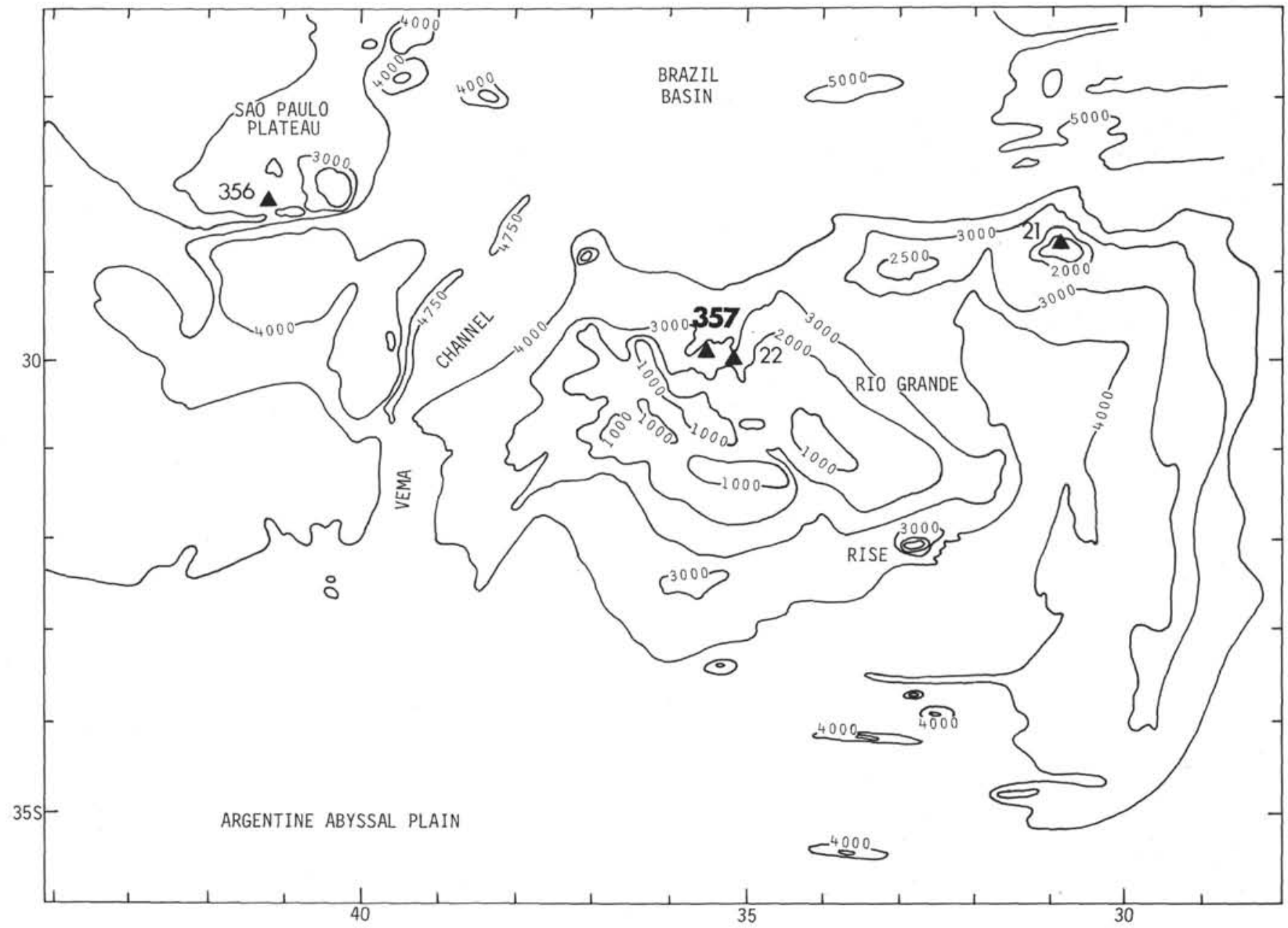

Figure 1. Base map of Rio Grande Rise showing location of Sites 357, 21, and 22. Contours in meters from Connary and Moody, 1975, Bathymetry of the continental margin of Brazil (unpublished). 


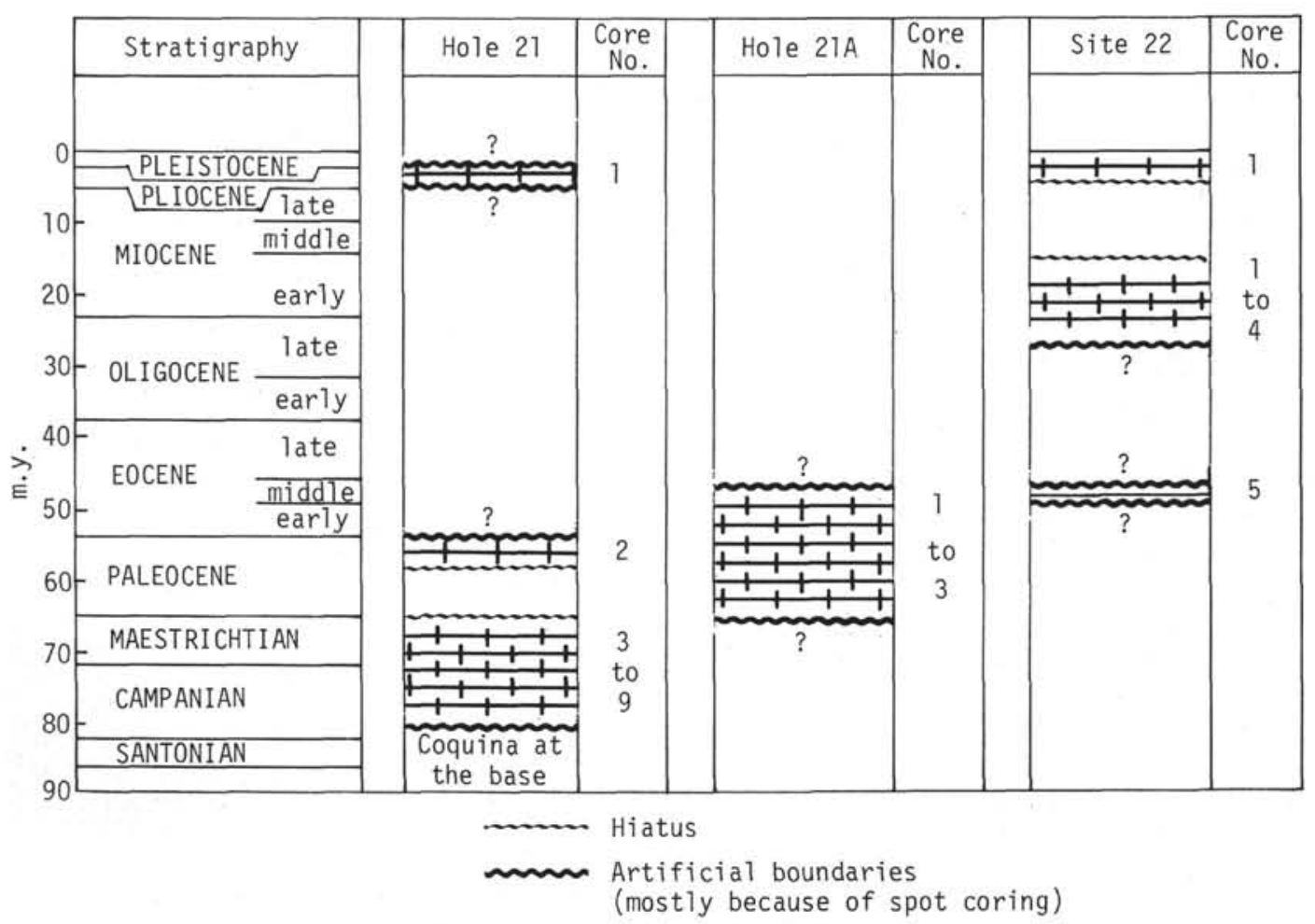

Figure 2. Lithologies of Sites 21 and 22 (DSDP Leg 3) plotted against age. Because of spot coring, large artificial gaps exist in the cored sections. After data in Maxwell, Von Herzen, et al., 1970.

greatly limited the usefulness of the results obtained at these two sites. The most significant result was recovery of a white coquina, Campanian or pre-Campanian in age, found as "basement" at Site 21 (eastern Rio Grande Rise). Cores from the sediments overlying the coquina (Holes 21 and 21A) contain Campanian, Maestrichtian, upper Paleocene, lower and middle Eocene, and Pliocene sections of the sedimentary sequence. Five cores from Site 22 add control in the upper Oligocene and lower Miocene.

Because of the limited amount of information available from Sites 21 and 22, an additional site on the northern flank of Rio Grande Rise was very desirable. An apparently pelagic sedimentary sequence covers this area. The site was to be drilled close to Site 22; site location was to be based on existing reflection profiles. The sedimentary section overlies well-defined acoustic basement of unknown age and nature, and contains two to three well-defined intermediate reflectors. Total sediment thickness varies regionally between 0.5 and $1.0 \mathrm{sec}$. The site was to be located in shallowest water and thinnest possible sediment section where all layers are well developed. The following objectives were to be achieved:

1) To complement the data already available from Sites 21 and 22, and to construct a regionally valid history of Cenozoic and Mesozoic sedimentation on the rise. We expected these sediments to be mostly pelagic calcareous oozes or their consolidated equivalents. The calcareous components were likely to be very well preserved because of the relatively shallow water depth.
2) To recover as complete a calcareous section as possible, for biostratigraphic purposes. It was especially important to recover those portions of the stratigraphic column represented elsewhere in the western South Atlantic Ocean by hiatuses. It was important to recover a complete section of the uppermost Cretaceous and the lowermost Tertiary sediments.

3) To define the age and nature of the prominent regional reflectors.

4) To establish the nature and, we hoped, the age (at least a minimum age) of the seismic basement.

5) To reach crystalline basement if possible; to establish whether it is continental or oceanic in origin, and to determine its age.

\section{OPERATIONS}

Glomar Challenger approached the vicinity of the proposed site on a course of $120^{\circ} \mathrm{T}$ (Figure 3). At $0630 Z, 23$ November, we changed course to $090^{\circ}$ to follow the track of the reference profile (Figure 4, 1510 $\mathrm{hr}$ on Lamont-Doherty profile 825, cruise Vema 26 ). We reduced speed to 6 knots at $0645 \mathrm{Z}$, and crossed the intended site at $0745 \mathrm{Z}$; the profile we obtained (Figure 5) was identical to the Vema profile. At $0752 Z$ we turned the ship onto a reciprocal course of $270^{\circ}$, dropped the beacon while underway at $0821 Z$, then retrieved geophysical gear and came about to lock onto the beacon. The site location is $30^{\circ} 00.25^{\prime} \mathrm{S}, 35^{\circ} 33.59^{\prime} \mathrm{W}$ (average of 31 satellite navigation fixes), atop a northsouth trending ridge on the northern flank of the Rio 


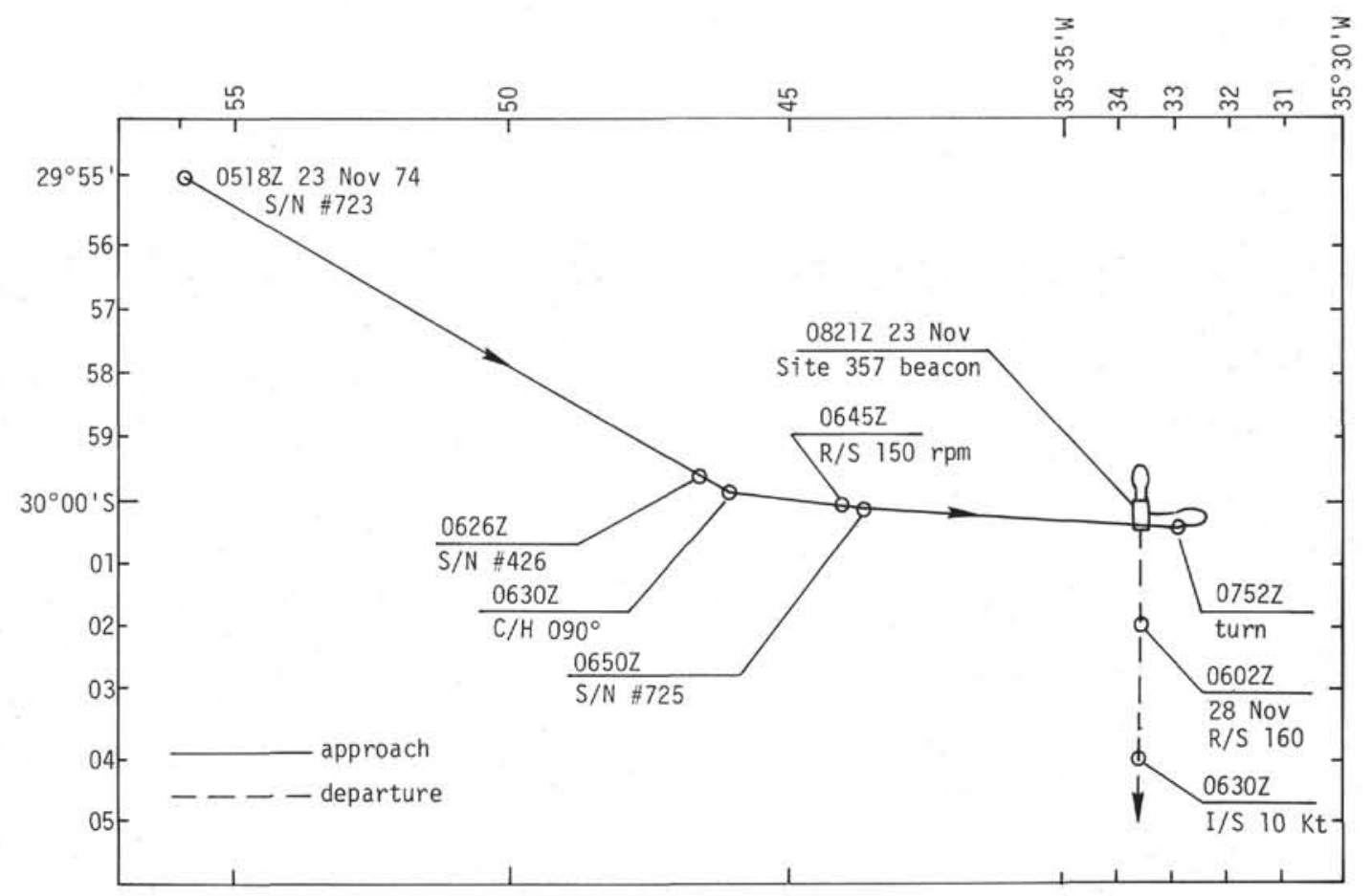

Figure 3. Glomar Challenger track in the vicinity of Site 357.

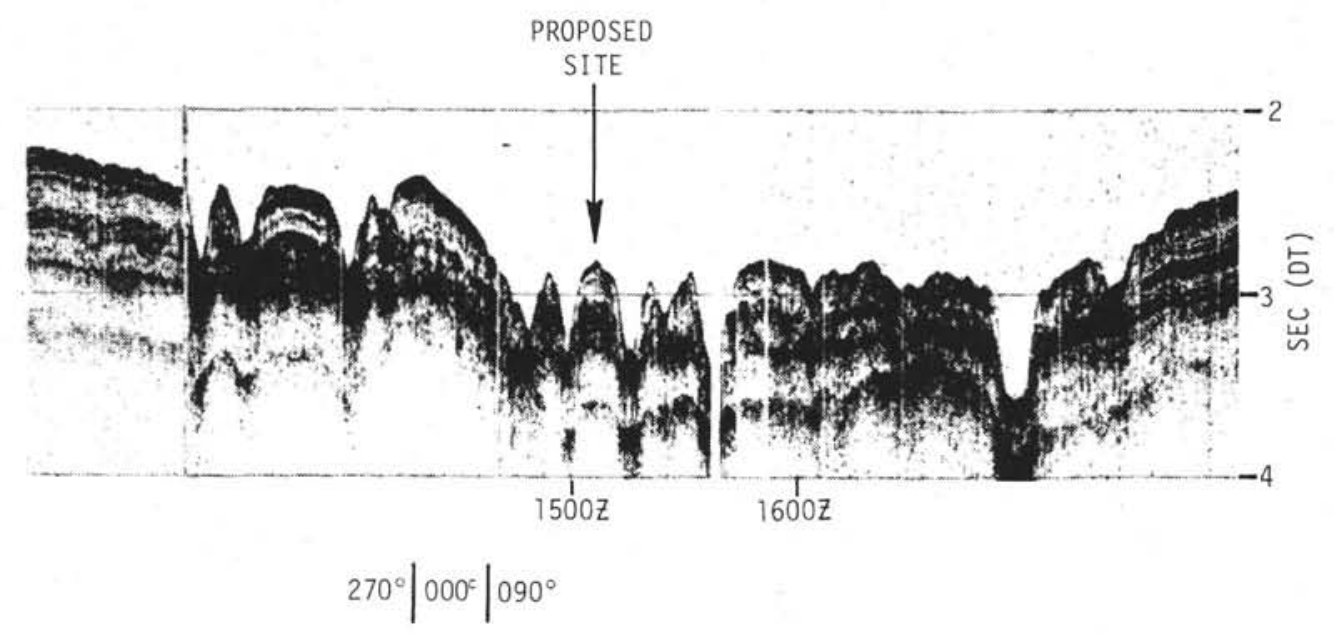

Figure 4. Lamont-Doherty Geological Observatory seismic profile 825, cruise Vema 26; proposed site located at $1510 \mathrm{hr}$.

Grande Rise, at exactly the spot suggested by the JOIDES Atlantic Advisory Panel (Figure 6).

We spudded the site at 1940 LCT 23 November 74. Water depth by PDR was 2086 meters, corrected; drill pipe measurement from the rig floor to the ocean bottom was 2109 meters; the PDR depth was accepted. We cut a total of 51 cores at Site 357. Table 1 lists depths of the cored and drilled intervals, Figure 7 shows variation of coring rate with depth. No equipment failures occurred during operations, except that an overshot pin sheared on Core 2, necessitating two sandline trips to retrieve this core. Coring and drilling rates were very slow in chalk and lime- stone-down to $5 \mathrm{~m} / \mathrm{hr}$ (coring rate) in the marly limestone at the base of the section.

One of the most difficult and painful decisions of Leg 39 was to abandon Site 357 . The original schedule required us to begin pulling pipe at 0500 LCT 27 November; instead, we delayed until $2100 \mathrm{hr}$ in order to give ourselves every opportunity to hit acoustic basement. Because of the extremely slow coring rate, we had reached only 796.5 meters by $1900 \mathrm{hr}$. On the basis of sonic velocity measurements made onboard, we felt that we might have passed the depth of the lowest visible reflector, and that this reflector might well represent the Santonian marly limestone rather than 


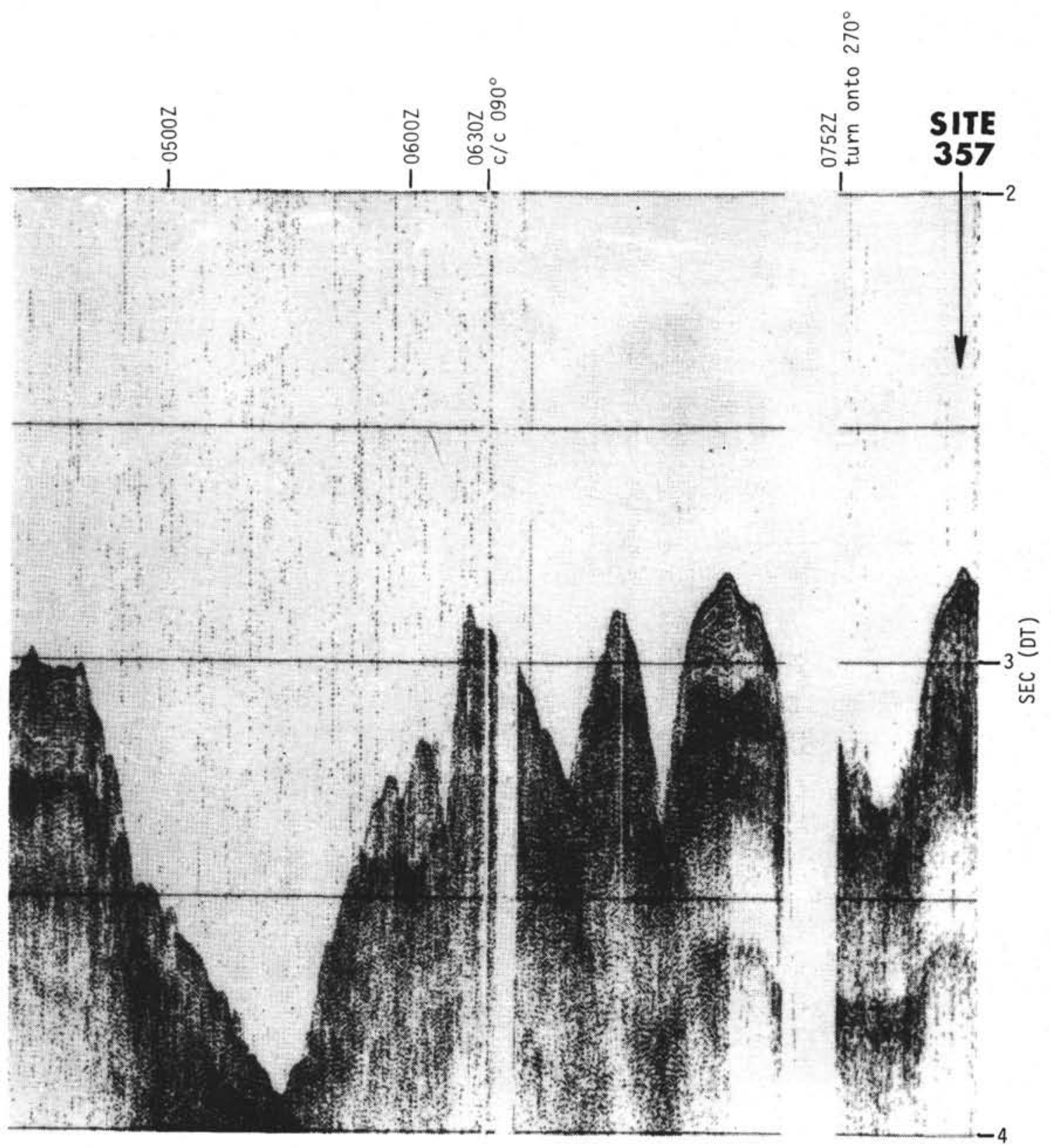

Figure 5. Glomar Challenger seismic reflection profile, shot on approach to Site 357.

igneous basement. Any further time at Site 357 would have made impossible any meaningful operations at the last site, the Argentine Basin. We considered cancelling the Argentine Basin site, but in view of our uncertainty as to the nature and depth of the Rio Grande Rise basement, and the critical importance of the Argentine Basin drilling for Atlantic Ocean paleooceanography, we elected to abandon further drilling at Site 357 .

Glomar Challenger left Site 357 at $0527 \mathrm{Z} 28$ November on a northerly course to stream gear, then turned onto $182^{\circ}$ and proceeded toward Site 358 in the Argentine Basin.

\section{LITHOLOGIC SUMMARY}

Although the sedimentary sequence consists chiefly of calcareous pelagic oozes and their consol- idated/recrystallized equivalents, it is possible to define five lithologic units, one of them consisting mainly of volcanic breccia (Figures 8 and 9 and Table 2).

\section{Unit 1}

The youngest sediments at this site (representing early Miocene through Pleistocene) are soupy, homogeneous, foraminifer-nannofossil oozes, grayish-orange to pinkish-gray, composed primarily of planktonic foraminifers, calcareous nannofossils (whose proportion increases considerably in the lowermost cores), and small amounts of benthic foraminifers, clay minerals, mica, and glauconite. Pteropods in the uppermost Pleistocene portion of this unit typify the excellent preservation of calcareous fossils.

All sedimentary structures have been disturbed by the drilling/coring process, resulting in a rather 


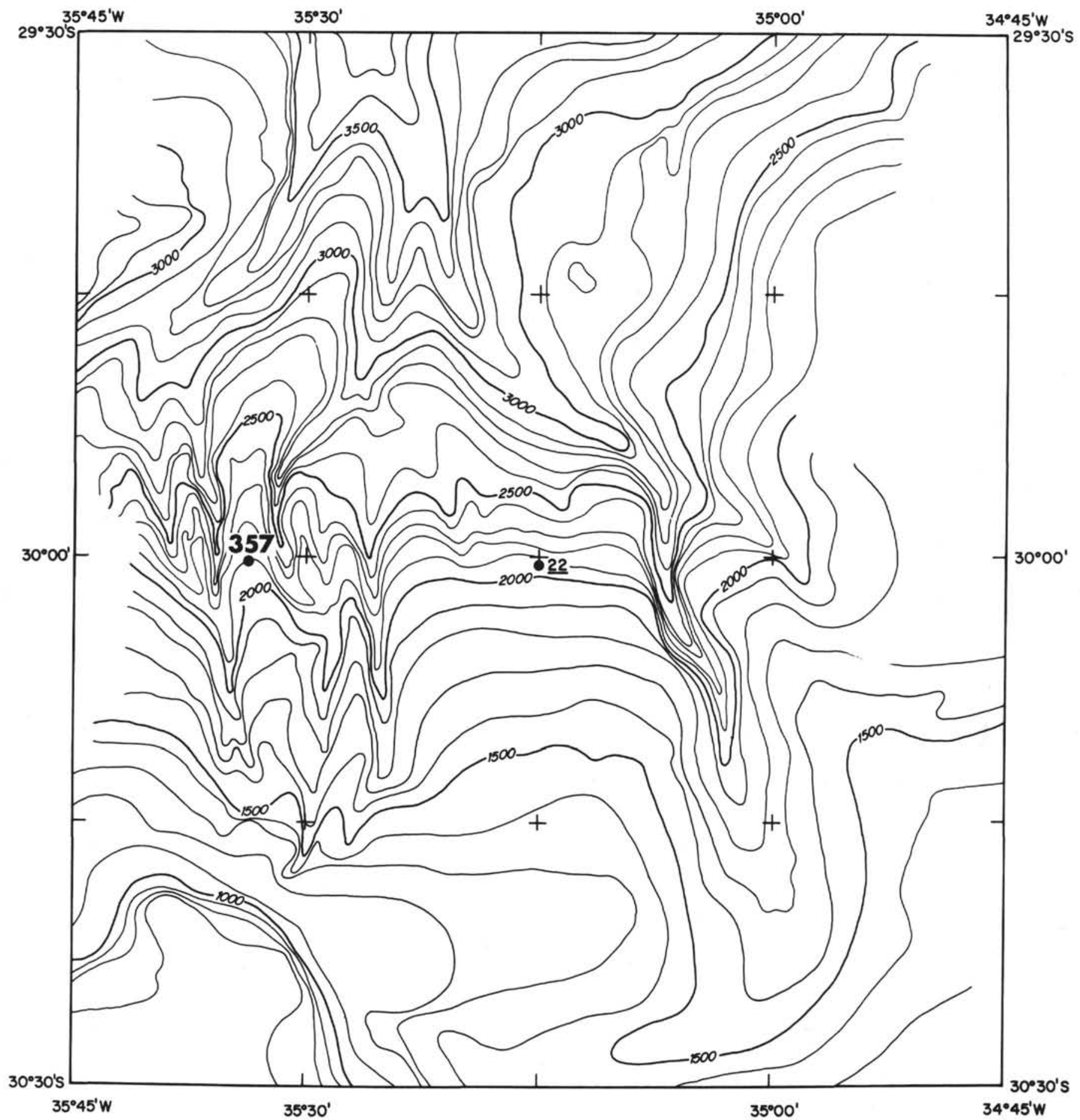

Figure 6. Detailed bathymetry in the vicinity of Site 357. Courtesy D. Johnson, Woods Hole Oceanographic Institution.

homogenized sediment in the uppermost cores; in Cores 6 and 7, however, the sediment is stiff enough that sedimentary structures are to a certain degree preserved. Small lumps of whitish nannofossil ooze occur in Core 5. Cores 6 and 7 have numerous, thin (1-2 $\mathrm{cm}$ thick) layers, pale yellow-brown to very pale orange. The layers are slightly mottled, but essentially similar in composition to the dominant sediment. They are intercalated with the dominant pinkish-gray foraminifer-nannofossil oozes, which suggests that the soupy homogeneous sediment of the upper five cores may be representative of the composition of this unit, but not of its texture or sedimentary structures. This unit differs from Unit 2 in its considerably higher content of planktonic foraminifers and its different color.

\section{Unit 2}

Unit 2 is the thickest lithologic unit at Site 357 . It represents deposits of early Eocene to early Miocene 
TABLE 1

Coring Summary, Site 357

\begin{tabular}{|c|c|c|c|c|}
\hline Core & $\begin{array}{l}\text { Depth Below } \\
\text { Sea Floor } \\
\text { (m) }\end{array}$ & $\begin{array}{l}\text { Length } \\
\text { Cored } \\
\text { (m) }\end{array}$ & $\begin{array}{l}\text { Length } \\
\text { Recovered } \\
\text { (m) }\end{array}$ & $\begin{array}{c}\text { Recovery } \\
(\%)\end{array}$ \\
\hline 1 & $0.0-8.5$ & 8.5 & 8.5 & 100 \\
\hline 2 & $8.5-18.0$ & 9.5 & 9.5 & 100 \\
\hline 3 & $18.0-27.5$ & 9.5 & 8.1 & 85 \\
\hline 4 & $27.5-37.0$ & 9.5 & 9.0 & 95 \\
\hline 5 & $37.0-46.5$ & 9.5 & 8.3 & 87 \\
\hline 6 & $46.5-56.0$ & 9.5 & 8.9 & 94 \\
\hline 7 & $56.0-65.5$ & 9.5 & 9.1 & 96 \\
\hline 8 & $65.5-75.0$ & 9.5 & 8.8 & 93 \\
\hline 9 & $75.0-84.5$ & 9.5 & 9.4 & 99 \\
\hline 10 & $94.0-103.5$ & 9.5 & 6.0 & 63 \\
\hline 11 & $103.5-113.0$ & 9.5 & 1.9 & 20 \\
\hline 12 & $113.0-122.5$ & 9.5 & 8.6 & 91 \\
\hline 13 & $132.0-141.5$ & 9.5 & 9.5 & 100 \\
\hline 14 & $151.0-160.5$ & 9.5 & 3.1 & 33 \\
\hline 15 & $170.0-179.5$ & 9.5 & 1.9 & 20 \\
\hline 16 & $179.5-189.0$ & 9.5 & 3.0 & 32 \\
\hline 17 & $189.0-198.5$ & 9.5 & 8.6 & 91 \\
\hline 18 & $208.0-217.5$ & 9.5 & 3.4 & 36 \\
\hline 19 & $236.5-246.0$ & 9.5 & 2.6 & 27 \\
\hline 20 & $255.5-265.0$ & 9.5 & 3.6 & 38 \\
\hline 21 & $284.0-293.5$ & 9.5 & 4.0 & 42 \\
\hline 22 & $303.0-312.5$ & 9.5 & 7.5 & 79 \\
\hline 23 & $331.5-341.0$ & 9.5 & 9.5 & 100 \\
\hline 24 & $350.5-360.0$ & 9.5 & 9.1 & 96 \\
\hline 25 & $369.5-379.0$ & 9.5 & 4.5 & 47 \\
\hline 26 & $379.0-388.5$ & 9.5 & 9.5 & 100 \\
\hline 27 & $407.5-417.0$ & 9.5 & 9.5 & 100 \\
\hline 28 & $436.0-445.5$ & 9.5 & 9.5 & 100 \\
\hline 29 & $464.5-474.0$ & 9.5 & 3.0 & 32 \\
\hline 30 & $474.0-483.5$ & 9.5 & 9.5 & 100 \\
\hline 31 & $493.0-502.5$ & 9.5 & 5.0 & 50 \\
\hline 32 & $502.5-512.0$ & 9.5 & 7.4 & 78 \\
\hline 33 & $521.5-531.0$ & 9.5 & 8.6 & 91 \\
\hline 34 & $550.0-559.5$ & 9.5 & 9.5 & 100 \\
\hline 35 & $578.5-588.0$ & 9.5 & 6.3 & 66 \\
\hline 36 & $607.0-616.5$ & 9.5 & 8.5 & 89 \\
\hline 37 & $645.0-654.5$ & 9.5 & 0.2 & 2 \\
\hline 38 & $664.0-673.5$ & 9.5 & $\operatorname{Tr}$ & - \\
\hline 39 & $683.0-692.5$ & 9.5 & 1.4 & 15 \\
\hline 40 & $692.5-702.0$ & 9.5 & 8.1 & 85 \\
\hline 41 & $703.0-711.5$ & 8.5 & 7.3 & 86 \\
\hline 42 & $711.5-721.0$ & 9.5 & 7.1 & 75 \\
\hline 43 & $721.0-730.5$ & 9.5 & 9.5 & 100 \\
\hline 44 & $730.5-740.0$ & 9.5 & 7.8 & 82 \\
\hline 45 & $740.0-743.0$ & 3.0 & 1.9 & 63 \\
\hline 46 & $743.0-749.5$ & 6.5 & 4.9 & 75 \\
\hline 47 & $749.5-759.0$ & 9.5 & 9.5 & 100 \\
\hline 48 & $759.0-768.5$ & 9.5 & 8.7 & 92 \\
\hline 49 & $768.5-778.0$ & 9.5 & 8.0 & 84 \\
\hline 50 & $778.0-787.5$ & 9.5 & 9.5 & 100 \\
\hline 51 & $787.5-797.0$ & 9.5 & 8.6 & 91 \\
\hline Total & & 473.0 & 345.2 & 73 \\
\hline
\end{tabular}

age, and includes Unit 3 , volcanic breccia and dolostone (see below). The bulk of sediments belonging to Unit 2 are very light gray to bluish-white, and in the lower part, occasionally pinkish-gray calcareous oozes and their consolidated/recrystallized equivalents. Sediments of this unit consist mainly of calcareous nannofossils, which in the lower part increasingly give way to authigenic carbonate. The increasing proportion of authigenic carbonate coincides generally with increasing encrustation of the surviving calcareous nannofossils and planktonic foraminifer shells. Besides these components, siliceous fossils (diatom remains,

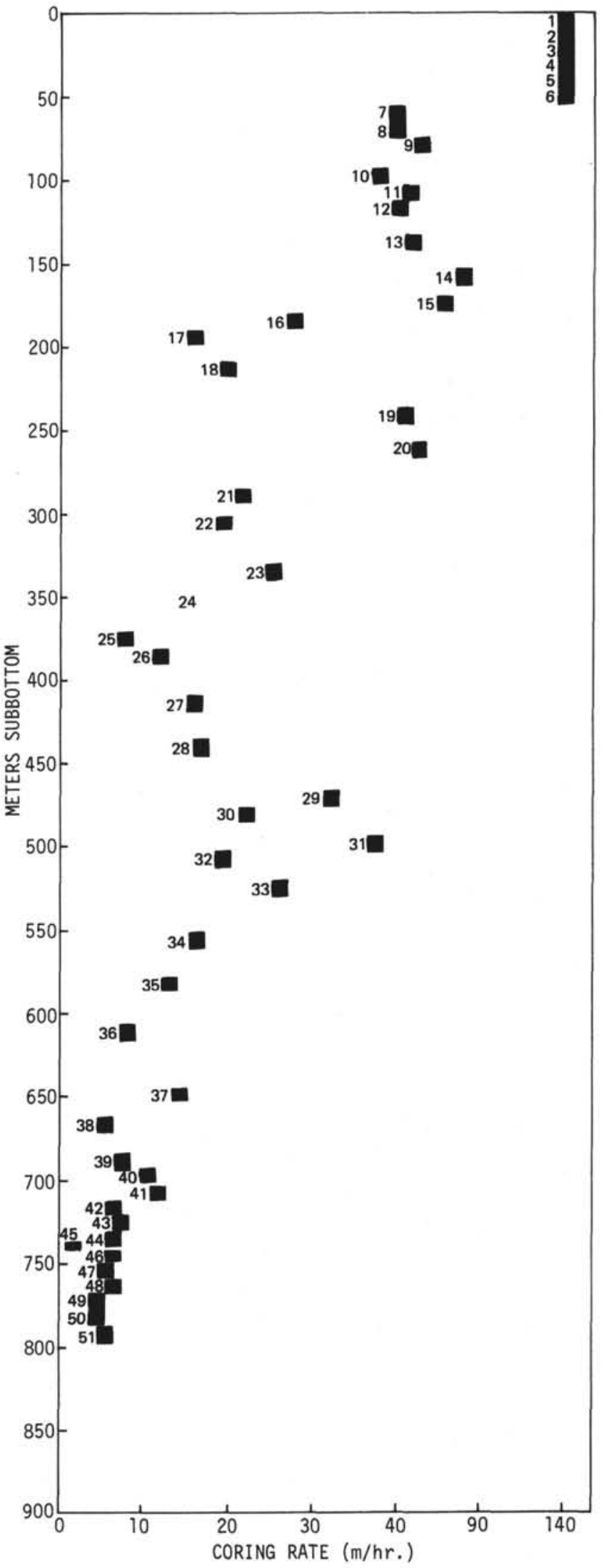

Figure 7. Coring rates, Site 357.

radiolarians, sponge spicules) are common here and there throughout the whole unit. They are best 


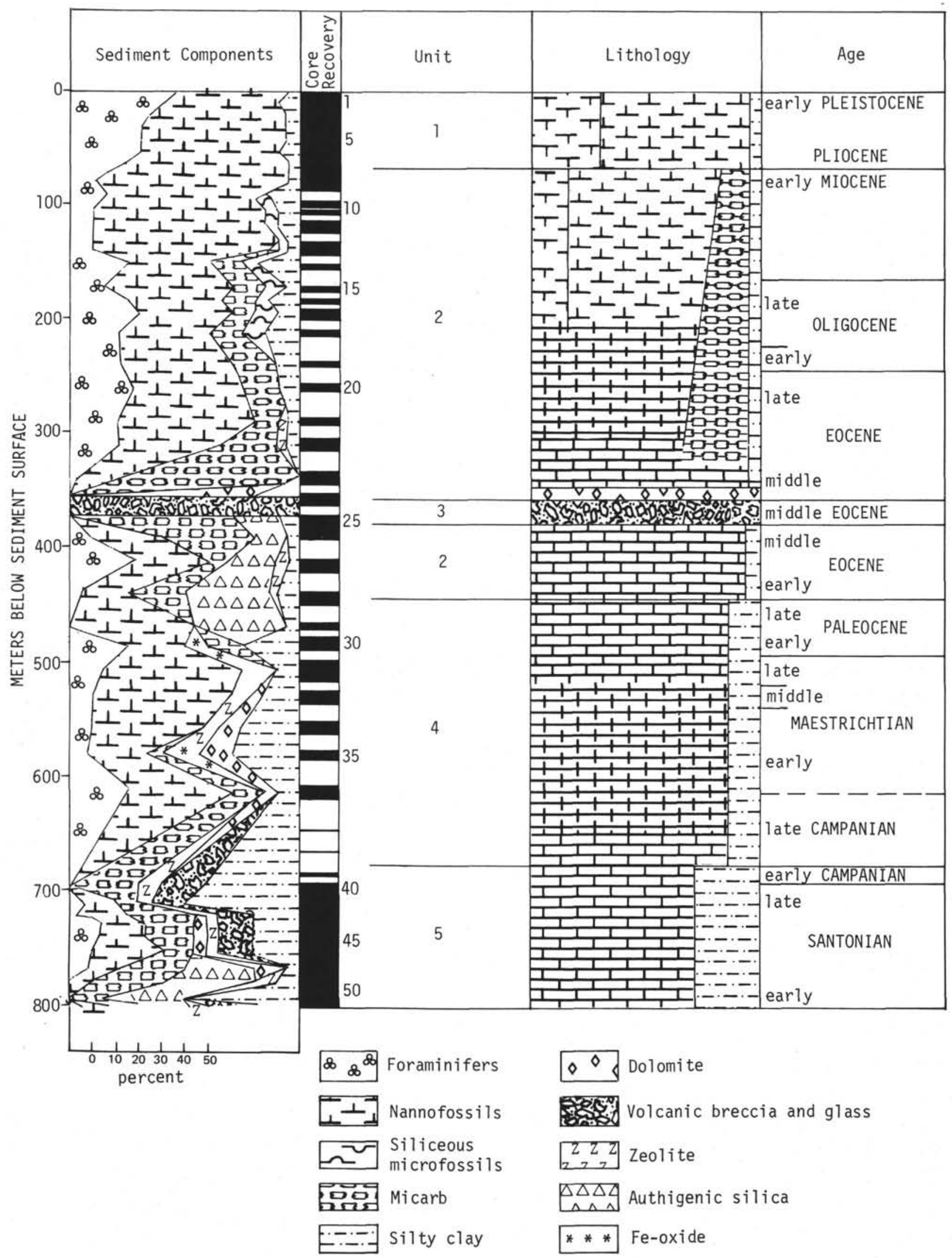

Figure 8. Simplified lithology and stratigraphy of penetrated sediment section. The left column, showing the distribution of main sedimentary components. is based on smear-slide analyses carried out by the sedimentologists of the shipboard scientific party. 


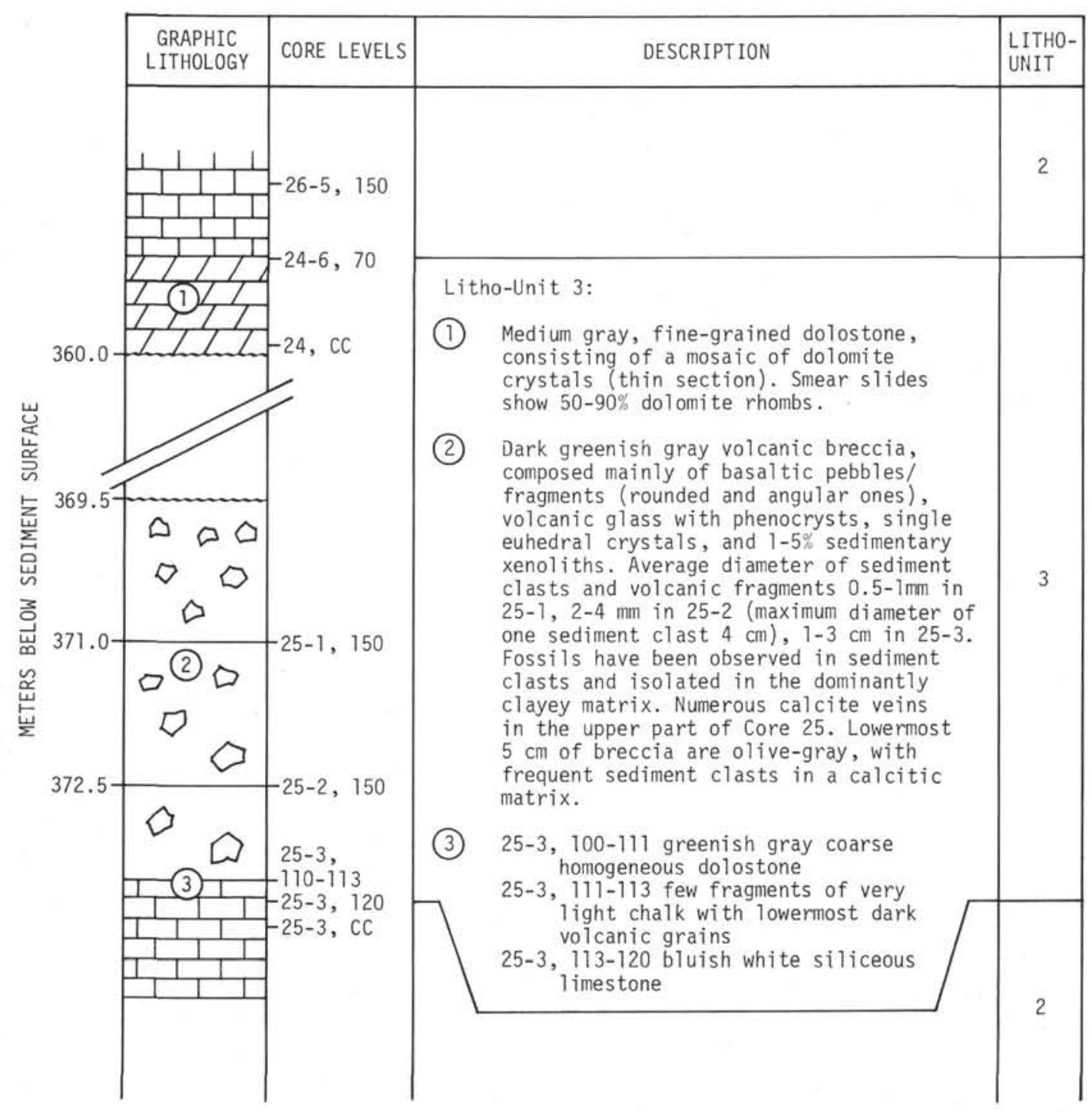

Figure 9. Details of lithologic Unit 3, a volcanic breccia into middle Eocene sediments of Unit 2.

preserved in the upper portion, but almost completely missing in the portion where chert stringers occur (Cores 21 to 24). Minor components are volcanic glass, clay, quartz (mostly angular, silt-sized), and feldspar. Besides authigenic carbonate, the pyrite, silica cement, and chert are diagenetic. The chert, very scarce, occurs as yellowish-brown stringers (Cores $21, \mathrm{CC}, 22,23,24)$. The transition from a nannofossil ooze to a nannofossil chalk occurs approximately between Cores 14 and 15 , and the transition from nannofossil chalk to limestone occurs between Cores 22 and 23 .

Burrows occur abundantly throughout this unit, the cores below Unit 3 are the most intensively burrowed. The most abundant type is Zoophycos, which occurs more frequently with increasing depth. Chondroid and large pipe-shaped burrows (including composites up to $5 \mathrm{~cm}$ in diameter) also occur, usually parallel to the bedding, but also oriented vertically and oblique to it. Burrows are sometimes pyrite coated, and appear as dark rings on the cut surfaces of the sections. Faint changes in hues indicate bedding planes. Occasional clayey and pyritiferous laminae are present, despite the common burrows.
Thin sandy layers are present in the cores just above and below Unit 3. Their maximum thickness is about $10 \mathrm{~cm}$, decreasing in thickness and number up the cores. In several places, their horizontal continuity has been destroyed by burrowing animals, and their former presence is revealed only by the coarsened contents of a number of burrows at the same level. These layers contain, in addition to the regular sediment components of this unit, glauconite, quartz, feldspar, and more siliceous fossils than the dominant finegrained portion. Their distinct appearance in the sediment (sometimes with a sharp contact below, but grading into normal sediment above) and their graded bedding (though infrequent) suggest that these layers are composed of displaced material introduced into the normal calcareous pelagic sediment facies. A dark green, very fine grained clay in Section 24-5, however, is assumed to be altered volcanic ash.

Diagenetic changes have not only altered the foraminifer-nannofossil oozes to their chalk and limestone equivalents, but have also resulted in intensive dissolution of siliceous fossils. Authigenic silica occurs in several varieties: small brownish-gray chert stringers 
TABLE 2

Lithologic Summary, Site 357

\begin{tabular}{|c|c|c|c|c|c|}
\hline Unit & Cores & $\begin{array}{l}\text { Depth Below } \\
\text { Sea Floor } \\
\text { (m) }\end{array}$ & $\begin{array}{l}\text { Thickness } \\
\text { (m) }\end{array}$ & Age & Description \\
\hline 1 & $1-7$ & $\begin{array}{r}0- \\
65.5\end{array}$ & 65.5 & $\begin{array}{l}\text { Early Pleistocene } \\
\text { to early Miocene }\end{array}$ & $\begin{array}{l}\text { Unconsolidated nanno- } \\
\text { fossil-foraminifer ooze } \\
\text { (grayish-orange to } \\
\text { pinkish gray) }\end{array}$ \\
\hline 2 & $\begin{array}{c}8-24 \\
\text { and } \\
25-28\end{array}$ & $\begin{array}{l}65.5- \\
358.0 \\
\text { and } \\
373.5- \\
443.2\end{array}$ & $\begin{array}{l}292.5 \\
\text { and } \\
70.0\end{array}$ & $\begin{array}{l}\text { Early Miocene to } \\
\text { middle Eocene } \\
\text { and middle Eo- } \\
\text { cene to early } \\
\text { Eocene }\end{array}$ & $\begin{array}{l}\text { Unconsolidated foram- } \\
\text { inifer-nannofossil ooze, } \\
\text { grading into nannofossil } \\
\text { chalk and limestone } \\
\text { (very light gray) }\end{array}$ \\
\hline 3 & $24-25$ & $\begin{array}{l}358.0- \\
373.5\end{array}$ & 15.5 & Middle Eocene & $\begin{array}{l}\text { Volcanic breccia (dark } \\
\text { greenish-gray) and } \\
\text { dolostone (dark gray), } \\
\text { which overlay as well } \\
\text { as underly the volcanic } \\
\text { breccia }\end{array}$ \\
\hline 4 & $28-38$ & $\begin{array}{l}443.2- \\
673.5\end{array}$ & 230.3 & $\begin{array}{l}\text { Early Eocene } \\
\text { to late } \\
\text { Campanian }\end{array}$ & $\begin{array}{l}\text { Limestone to nanno- } \\
\text { fossil chalk (orange- } \\
\text { gray to brown) }\end{array}$ \\
\hline 5 & $38-51$ & $\begin{array}{l}673.5- \\
797.0\end{array}$ & 123.5 & $\begin{array}{l}\text { Late Campanian } \\
\text { to Santonian }\end{array}$ & $\begin{array}{l}\text { Marly limestone } \\
\text { (greenish-gray), inten- } \\
\text { sively laminated in its } \\
\text { lower part }\end{array}$ \\
\hline
\end{tabular}

(only in Cores 21, 22, 23, and 24), siliceous cement (especially in the lowermost part of this unit), and siliceous chamber fillings of foraminifers.

This unit differs from those above and below in content of main components and in color. The contact to Unit 1 is gradational; a sharp color change from very light gray to pinkish-gray hues marks the contact to Unit 4 below.

\section{Unit 3}

This unit lies within the lower part of Unit 2. The composition of Unit 3 is different from all other rocks encountered at Site 357; since for the most part it is mainly displaced material, it deserves classification as a separate unit (see Figure 9). Its total thickness is 15.5 meters, 9.5 meters of which were not recovered, however, because coring was discontinuous. The position of the boundary between the uppermost dolostone and the breccia is thus unknown. Portions of the sequence, presumably minor, seem also to be missing between pieces of the breccia, and between the lowermost sediment layers, since the contacts between these look artificial, owing perhaps to drilling disturbance.

The 5-cm-thick sediment layer at the base of this unit is bluish-white siliceous limestone, fine-grained, homogeneous, slightly burrowed, and glauconitebearing, which differs from the Unit 2 limestone below in color and composition. At its upper boundary are a few fragments of very light gray chalk, containing the lowermost dark volcanic grains (basaltic glass). Since these chalk fragments are loose in the core, we do not know whether they represent a separate thin layer below the volcanic breccia proper or are simply misplaced.

About $12 \mathrm{~cm}$ of greenish-gray homogeneous dolostone, directly below the volcanic breccia, overlies these fragments. The lowermost contact of the breccia with calcareous sediment is preserved as a thin, light gray rim of chalk, different in color and composition from the dolostone. The lowermost $5 \mathrm{~cm}$ of the breccia are cemented by a calcitic matrix, possibly recrystallized ooze, and contain considerably more sediment clasts than the rest of the breccia.

The dominant components of this breccia are basaltic glass fragments, separate crystals, sediment clasts (partly fossiliferous), and separate fossils. The matrix above the lowermost $5 \mathrm{~cm}$ is dark greenish-gray clayey material. The sedimentary clasts and volcanic fragments are sorted according to size: average diameter is $1-3 \mathrm{~cm}$ in the basal layer, $2-4 \mathrm{~mm}$ in the upper part of Section 25-3, and 0.5-1.0 mm in Section 25-1.

The sediment clasts are silicified and unsilicified fossiliferous limestone; their maximum diameter decreases up the core from $4 \mathrm{~cm}$ to $1 \mathrm{~cm}$, paralleling the grading of the volcanic components from $4 \mathrm{~cm}$ to less than $1 \mathrm{~cm}$. Besides these limestones, red algae, planktonic and benthic foraminifers, and bivalve and gastropod shell fragments indicate that some of the material must have originated in relatively shallow water, presumably close to the source of the volcanic components. Sediment clasts and fossils occur more frequently in the lowermost and uppermost portions of the breccia. A thin section of the breccia showed mainly angular to subangular fragments $(\sim 2$ to $5 \mathrm{~mm})$ in a clayey matrix. Other fragments include foraminifers, mollusc shells, calcite crystals, and clinopyroxene and feldspar grains. A point count (1500 counts) of one thin section showed 43 volume percent matrix versus 57 percent fragments.

The basaltic fragments are highly altered to clay minerals, and vary from pale yellow to light green to 
gray. Each fragment contains tiny vesicles and bubbles, many filled with acicular microcrystalline material, possibly zeolites and carbonates. Unaltered grains of clinopyroxene also remain in the fragments.

Postdepositional white sparitic calcite veins (from $<1$ $\mathrm{mm}$ to several $\mathrm{cm}$ thick), mostly parallel or subparallel to the bedding, occur frequently in Sections 24-1 and 24-2, but are absent in the lower portion of the breccia.

Because of intermittent coring, the contact of the volcanic breccia with the overlying dark gray dolostone was not retrieved. The thickness of these two layers therefore remains unknown (but neither could have been thicker than the retrieved thickness plus $9.5 \mathrm{~m}$ ). However, the 120 -cm-thick dark gray dolostone in the lower part of Core 24 resembles the dolostone below the breccia, and contains volcanic glass. It thus seems reasonable to assume that deposition of this rock was associated with deposition of the volcanic breccia, and to include it in Unit 3. The contact of the dolostone with the overlying limestone of Unit 2 is sharp, but may be artificial, because of the coring process.

\section{Unit 4}

Unit 4 consists of Campanian to lower Eocene chalk and limestone and is 230.3 meters thick. The dominant color is pinkish-gray, with grayish-orange interchanging with pale yellowish-brown. An abrupt color change, from pinkish-gray to brown to very light gray, characterizes the uppermost contact of this unit. At the unit's lower limit, dominant brown grades into greenish-gray, the amount of terrigenous material, like that in Unit 5, increases considerably. The dominant rock type in the lower part of this unit is chalk, which grades upward into limestone; the transition occurs approximately in Core 32 . The limestone is mostly pinkish-gray to brown, and in the lower chalk (from Core 31 downward), light greenish-gray layers are intercalated with the browish sediments. The number of these layers and their proportion of the whole column increase gradually down the hole until the greenishgray hues dominate, thus marking the lower boundary of Unit 4.

The main components of this lithologic unit are calcareous nannofossils, clay minerals, iron oxides, and silica cement; siliceous fossils occur only sporadically. Increasing amounts of terrigenous material occur (clay, quartz, feldspar, mica) below Core 32 . In several layers, dolomite rhombs occupy up to $10 \%$ to $15 \%$ of the total sediment. Volcanic glass is present only in trace amounts.

Burrows-small chondroid forms, Zoophycos, and large, sometimes composite burrows-occur throughout this unit; in general, the darker layers (brown) are more intensively burrowed than the intermediate portion of the column. Sometimes a halo of reduced sediment occurs around burrows. Despite the burrows, thin laminae are occasionally preserved; apart from the above-mentioned layers, distinguished by color changes, they are almost the only preserved bedding. A $10-\mathrm{cm}$-thick, slightly contorted bed occurs in Core 34 . Deformation of the sediment interfaces is manifest as vertical to oblique small faults (usually not more than 1 $\mathrm{cm}$ vertical displacement). These small movements must have happened-at least partly-before final burial, since a small "graben" structure is filled with clay pebbles (Sample 32-3, 30-40 cm).

From Core 36-1 downward, Inoceramus fragments are characteristic macrofossils; they occur dispersed in the sediment or in abundance in intercalated layers (presumably where whole specimens have been crushed; see Figure 10). A small, but well-preserved intact specimen $(0-\sim 1 \mathrm{~cm})$ occurs in Sample $36-4,30$ $\mathrm{cm}$.

\section{Unit 5}

Greenish-gray marly chalks to silicified limestones, Santonian to Campanian in age, make up the lowermost 123.5 meters of the penetrated sedimentary column. The lower boundary of this unit remains unknown. We place its upper boundary where the abundance of terrigenous material decreases markedly, and where the dominant colors change from grayishgreen/pinkish-gray to brown. The sediments are fine grained and rather homogeneous throughout. The main components are authigenic carbonate, amorphous silica, calcareous nannofossils, planktonic foraminifers, and clay, with lesser quantities of quartz, feldspar, heavy minerals, volcanic glass shards, rare zeolites, dolomite rhombs, and pyrite. The $\mathrm{CaCO}_{3}$ content of this unit varies between $39 \%$ and $64 \%$ (carbonate bomb results). Siliceous fossils are almost completely absent. Abundance of Inoceramus and other bivalve shell fragments increases rapidly in the lowermost cores (Cores 43-51, Figure 10).

Most parts of this unit are intensively burrowed. Most burrows are slightly darker than the surrounding sediments, because of a pyrite coating and/or dispersed fine-grained pyrite in the burrow fillings. They comprise chondroid, elongate composite (parallel and perpendicular to the bedding planes) burrows and frequent Zoophycos. Only in the lowermost laminated part of this unit are burrows almost completely missing.

Single, slightly darker laminae are preserved in several places, despite the intensive burrowing. Laminae are absent in Cores $44-47$, but occupy an increasing proportion of the sedimentary column from Core 48 downwards, until the whole sediment is irregularly but densely laminated.

Besides the laminations and burrows described above, sedimentary structures occur in the form of bedding which is usually visible only as faintly changing hues, or as intercalations of distinct thin layers of clay. These layers are presumably altered volcanic ash. A typical such thin layer occurs in Sample 40-4, 40-50 cm: a dark green claystone bed, laminated in its lower part, has a thin clay pebble layer above. A similar layer occurs in Sample 41-2, 76-82 $\mathrm{cm}$. These beds represent expiring volcanic activity, probably close to this area.

In the oldest sediments of this site (Core 51) carbonate concretions up to $10 \mathrm{~cm}$ in diameter occur. The more clayey sediments around these are deformed in a fashion typical of concretions. Movements along small cracks may have resulted from differential settling of the concretions and the normal sediment column beside them. 
DISTRIBUTION OF BIG BIVALVE FRAGMENTS

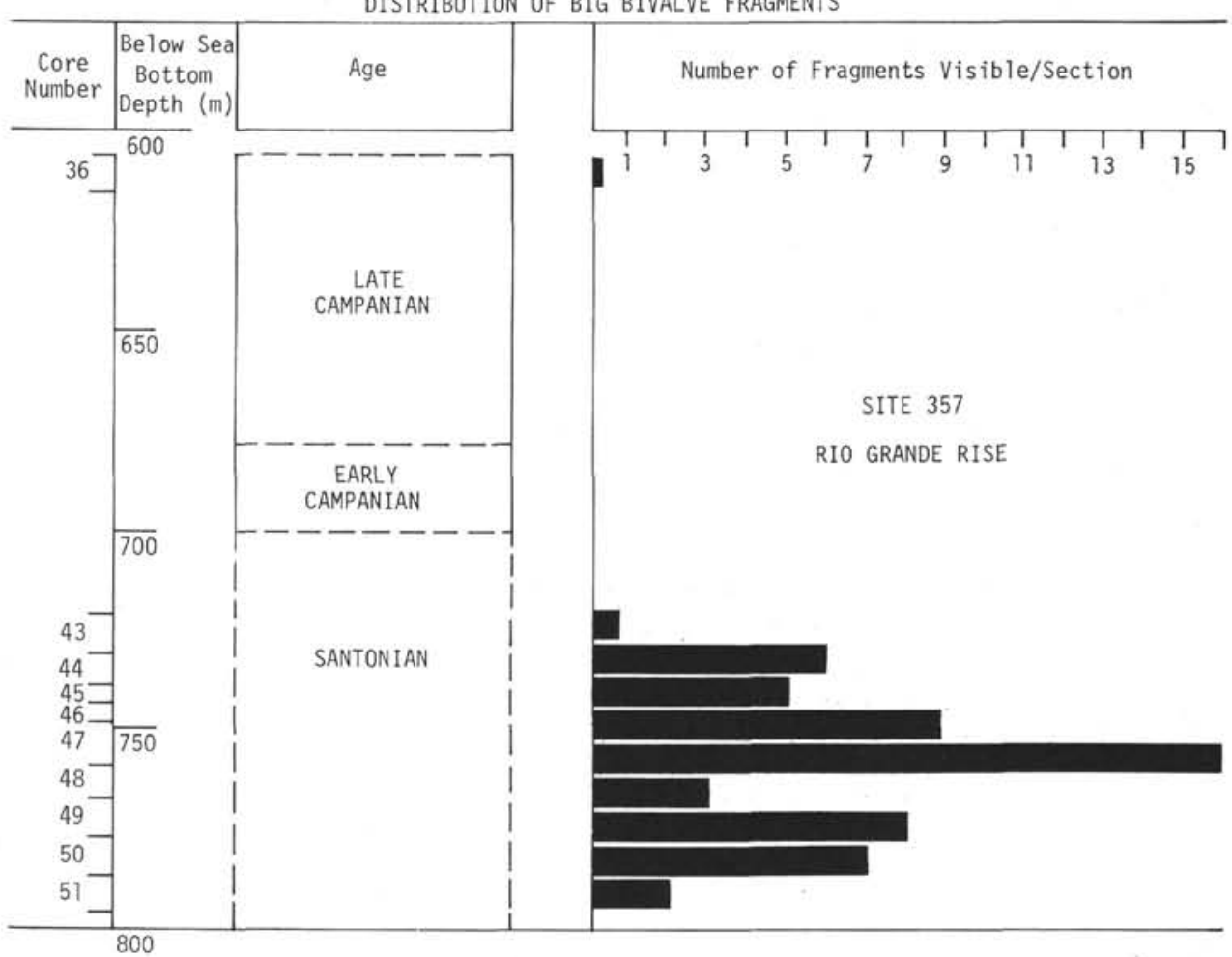

Figure 10. Distribution of large Inoceramus fragments (other bivalve shell fragments are included).

\section{Discussion}

The sediment components dominant in all units except Unit 3 are calcareous and pelagic. They have been diluted, however, by terrigenous and volcanogenic material in varying amounts, and have been deposited in different water depths under both reducing and oxidizing conditions.

The lowermost part of Unit 5 (Cores 49-51) is marly limestone and chalk, laminated throughout, and deposited under reducing conditions that prevented almost all benthic life. Benthic foraminifers in these cores may have been displaced, although they can tolerate an almost complete lack of dissolved oxygen in the water, as in the now-stagnant Santa Barbara Basin (for example: Phleger and Soutar, 1973; Sliter, 1975).

In Core 49 and those above, oxidizing conditions become evident, but layers reflecting oxidizing and reducing conditions alternate. More and more of the sediment is intensively burrowed, and the laminated portion of the sedimentary column diminishes rapidly. The greenish-gray color and the pyrite in this unit indicate, however, that the boundary between oxidizing and reducing conditions was just below the sediment/water interface, occasionally reaching the sediment surface (where laminae are preserved). Although the dominant color throughout Unit 5 remains greenish-gray, which usually indicates a reducing environment, conditions must have been suitable for benthic life at least in the uppermost layer, since the laminated portion rapidly gives way to burrowed sediments. These two facies alternate several times, indicating fluctuations of a boundary between reducing and oxidizing conditions, located either above or just below the sediment-water interface.

The facies of the lowermost part of Unit 4 resulted from a continuation of the same trend. The indications of reducing conditions (lamination of the sediment, pyrite, greenish-gray color) decrease gradually, as does the particulate terrigenous sediment. The change this reflects, however, was not continuous, but again seems to have occurred in pulses. The cause of this alternation between grayish reduced sediment and brownish burrowed oxidized sediment could be variation in the rate of input of terrigenous and organic material from outside the deposition area, or fluctuation of an oxygen boundary. In the lower part of Unit 4, the greenish and brownish layers alternate, but since no shallow water material occurs in these layers, and since they are similar in composition (except for authigenic pyrite and iron oxides) and texture, we favor the explanation involving a fluctuating oxygen boundary.

Large bivalve shell fragments (mainly of Inoceramus) occur frequently throughout Unit 5 , even in the laminated cores (see Figure 10). How to relate the Inoceramus fragments to these sediments remains an open question, since evidence for benthic life, except for sparse benthic foraminifers, seems to be missing at least in the lowermost two cores of this unit. Two possibilities are that Inoceramus was living as epibenthos on the sediment (Kauffmann, 1968), or that the shells and fragments are displaced. For further discussion of possible significance of Inoceramus in deep-sea sediments, see Thiede and Dinkelman (this volume). 
Another important characteristic of Unit 5 is the relatively high terrigenous component, which decreases in its uppermost part. The rapid decrease of terrigenous material in the transitional zone between Units 5 and 4 suggests that the source of this material must have disappeared or become disconnected during the Campanian. Since a considerable portion of this terrigenous material is silt-sized quartz and clay, one might consider it as coming from the continental margin under certain climatic conditions. Another, less likely possibility is that this material is weathered residue of differentiated products from a large volcanic island, represented by the structural high now forming the Rio Grande Rise. As the major part of this island's surface gradually submerged, and with it the source of weathered material, the input of quartz, clay, and finally Fe-oxide would have gradually decreased.

Unit 3 consists mainly of volcanic breccia, graded in size, but relatively homogenous in composition. Since its grain size decreases gradually upward through the whole unit, this breccia probably represents only one short depositional event. Ages of the volcanic components remain unknown. The occurrence of shallow-water limestones and fossils (large, shallowwater, calcareous benthic foraminifers and red algae), together with the volcanic fragments, proves that this deposit came from a former volcanic shoal, or even island, south of the site.

The dolostone below and above the volcanic breccia seems genetically related to deposition of the volcanic components. What appear to be calcite pseudomorphs after olivine suggest olivines in the breccia components. Also, the presence of calcite indicates considerable alteration of the mineral assemblages of these volcanic rocks. The magnesium necessary for dolomitization of the dolostone above and below the breccia may therefore have come from alteration of this volcanic material.

Clear, colorless volcanic glass shards occur in Units $2,3,4$, and 5 , generally becoming less abundant in the younger units. Higher concentrations occur several tmes in thin sandy layers which are also otherwise of different composition than the surrounding sediment. This suggests that concentration of glass shards in these layers may be a result of sorting rather than short-term input of volcanic ash.
Unit 2 is made up of limestone, chalk, and oozes; the degree of consolidation and/or recrystallization increases down the unit, from almost-soupy ooze to limestone. Rocks in this unit are similar to rocks recovered from the Rio Grande Rise during DSDP Leg 3 (Maxwell, Von Herzen, et al., 1970). Well-preserved opaline skeletons (silicoflagellates, diatoms, radiolarians, sponge spicules) occur only in the upper part of the unit. They are poorly preserved or absent in the lower portions, especially in the layers that contain chert stringers. Silica of diagenetic origin occurs as infrequent small chert stringers, as silica cement in the interstices of grains, and as fillings of foraminifer chambers.

The sediments of Unit 1 represent pure calcareous pelagic deposits in a subtropical ocean. The sediments consist essentially of calcareous nannofossils, planktonic foraminifers, and aragonitic pteropods. The calcareous fossils in this unit are all very well preserved. Because of the geographic location of this site, siliceous microfossils cannot be expected in large quantity; when present, they are either dissolved or masked by dilution with calcareous sediments. They occur only occasionally in this unit, in trace amounts.

\section{GEOCHEMISTRY}

We measured $p \mathrm{H}$, alkalinity, salinity, $\mathrm{Ca}^{++}$, and $\mathrm{Mg}^{++}$contents of 10 interstitial water samples onboard ship. Data appear in Table 3 and Figure 11.

\section{PHYSICAL PROPERTIES}

Physical properties data for Site 357 appear in Table 4 and Figure 12. The uppermost unit is foraminifernannofossil ooze, which grades into limestone extending to a depth of 358 meters. Moderate velocity, density, and water content gradients characterize the unit throughout. Velocities increase with depth from 1.55 to about $2.0 \mathrm{~km} / \mathrm{sec}$; wet bulk density increases from 1.7 to $2.0 \mathrm{~g} / \mathrm{cc}$, and the water content decreases from more than $30 \%$ to about $20 \%$. In each case, the gradient appears to increase slightly with depth.

A marked increase in the maximum densities of the dolostone, which reach values in excess of $2.0 \mathrm{~g} / \mathrm{cc}$, distinguishes the dolostone and breccia unit from the overlying limestone. The velocity of the associated breccia, measured on ship, is about $3.3 \mathrm{~km} / \mathrm{sec}$.

TABLE 3

Summary of Shipboard Geochemical Data

\begin{tabular}{lrccccc}
\hline $\begin{array}{c}\text { Sample } \\
\text { (Interval } \\
\text { in cm) }\end{array}$ & $\begin{array}{c}\text { Subdepth } \\
(\mathrm{m})\end{array}$ & $p \mathrm{H}$ & $\begin{array}{c}\text { Alkalinity } \\
(\mathrm{meq} / \mathrm{l})\end{array}$ & $\begin{array}{c}\text { Salinity } \\
(\% \circ)\end{array}$ & $\begin{array}{c}\mathrm{Ca}^{++} \\
(\mathrm{mmoles} / \mathrm{l})\end{array}$ & $\begin{array}{c}\mathrm{Mg}^{++} \\
(\mathrm{mmoles} / \mathrm{l})\end{array}$ \\
\hline $1-5,144-150$ & 7.5 & 7.44 & 2.79 & 34.6 & 10.79 & 53.05 \\
$6-5,144-150$ & 54.0 & 7.28 & 3.95 & 35.2 & 13.03 & 50.69 \\
$11-1,144-150$ & 105.0 & 7.19 & 4.16 & 35.2 & 14.24 & 48.63 \\
$15-1,144-150$ & 171.5 & 7.26 & 3.56 & 35.5 & 14.44 & 46.06 \\
$23-4,140-150$ & 337.5 & 7.63 & 1.30 & 35.2 & 15.75 & 43.96 \\
$24-5,144-150$ & 358.0 & 7.55 & 1.80 & 35.8 & 17.50 & 45.68 \\
$26-5,144-150$ & 386.5 & 7.31 & 2.82 & 35.5 & 17.99 & 47.29 \\
$29-1,0-10$ & 466.0 & 7.01 & 6.30 & 36.0 & 19.98 & 38.22 \\
$31-3,144-150$ & 497.5 & 6.90 & 7.40 & 36.3 & 21.59 & 38.79 \\
$36-4,140-150$ & 613.0 & 6.94 & 5.54 & 36.5 & 22.51 & 38.95 \\
\hline
\end{tabular}



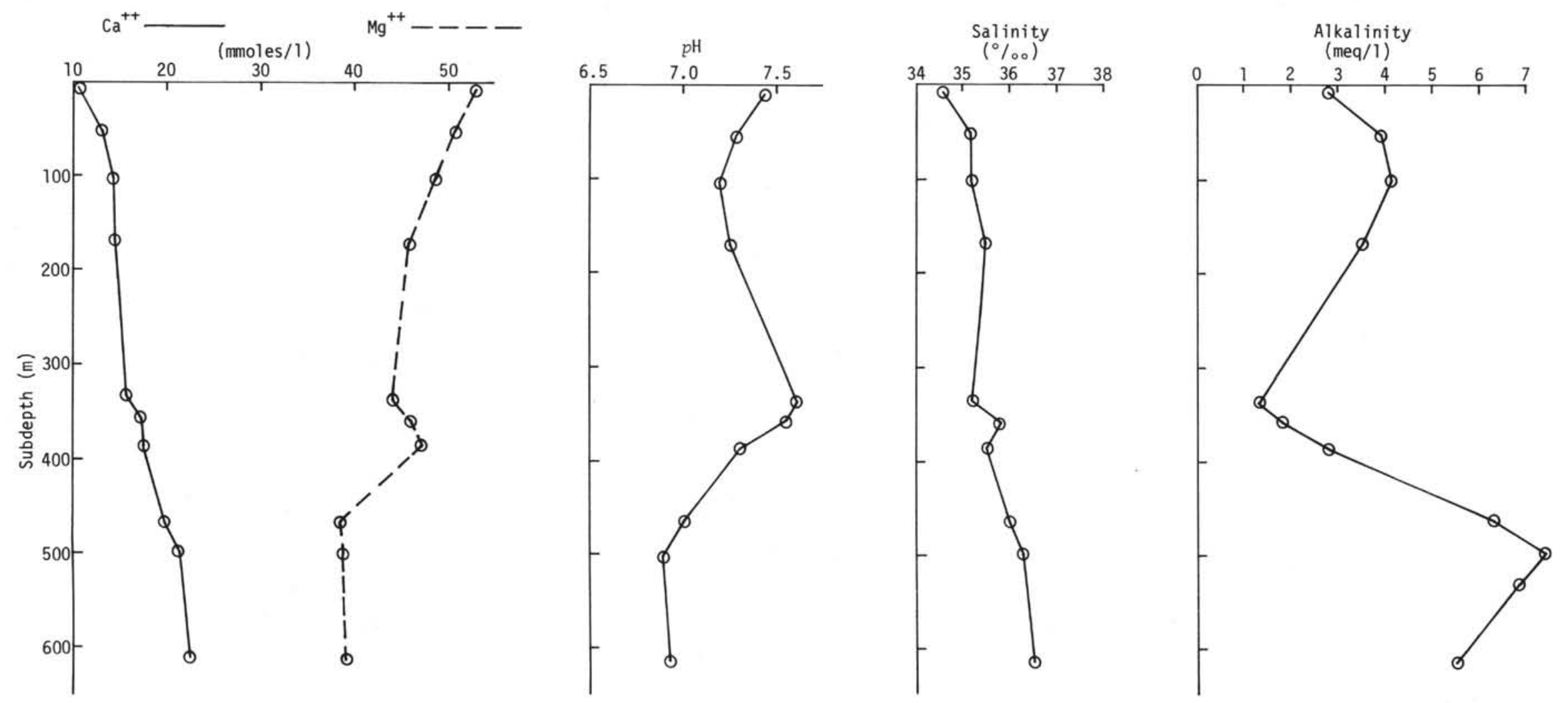

Figure 11. $\mathrm{pH}$, salinity, alkalinity, $\mathrm{Ca}^{++}$, and $\mathrm{Mg}++$ content, of interstitial waters versus depth, Site 357. 


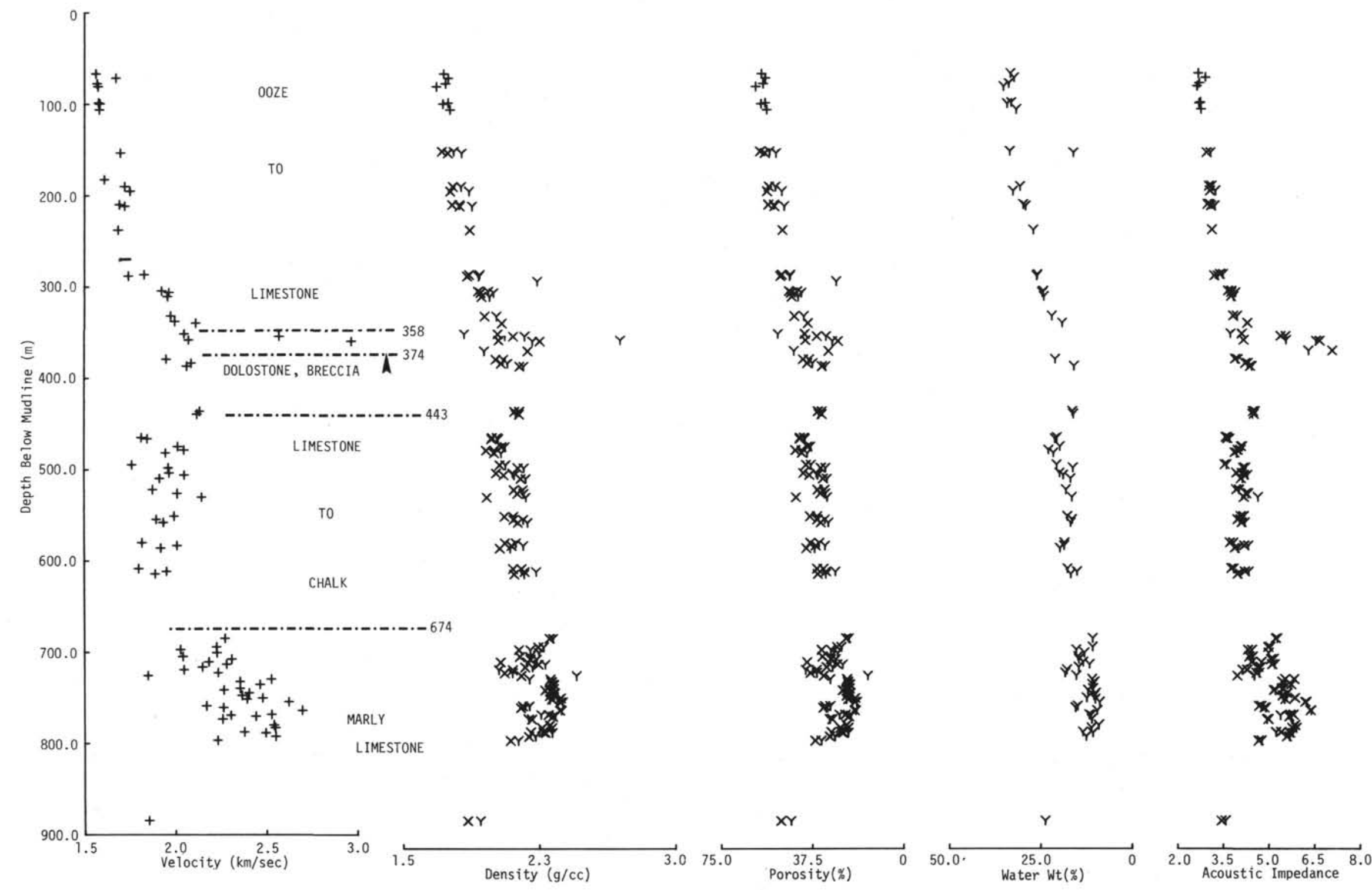

Figure 12. Physical properties versus depth;,$+ x$, and y represent syringe, immersion, and GRAPE values, respectively. 
TABLE 4

Physical Properties Data, Site 357

\begin{tabular}{|c|c|c|c|c|c|c|c|c|c|c|c|c|}
\hline \multirow{2}{*}{$\begin{array}{l}\text { Sample } \\
\text { (Interval } \\
\text { in } \mathrm{cm} \text { ) }\end{array}$} & \multirow{2}{*}{$\begin{array}{l}\text { Depth } \\
\text { (m) }\end{array}$} & \multirow{2}{*}{$\begin{array}{l}\text { Velocity } \\
(\mathrm{km} / \mathrm{sec})\end{array}$} & \multicolumn{3}{|c|}{ Density $(\mathrm{g} / \mathrm{cc})$} & \multirow{2}{*}{$\begin{array}{c}\text { Water } \\
(\mathrm{Wt} \%)\end{array}$} & \multicolumn{3}{|c|}{ Porosity (\%) } & \multicolumn{3}{|c|}{ Acoustic Impedance } \\
\hline & & & $\mathrm{S}$ & I & G & & $S$ & I & G & $\mathrm{S}$ & I & G \\
\hline $8-1,89$ & 66.39 & 1.562 & 1.723 & - & - & 33.25 & 58.33 & - & - & 2.69 & - & - \\
\hline $8-4,100$ & 71.00 & 1.672 & 1.749 & - & - & 32.25 & 56.78 & - & - & 2.92 & - & - \\
\hline $9-2,83$ & 77.33 & 1.569 & 1.734 & - & - & 33.70 & 57.67 & - & - & 2.72 & - & - \\
\hline $9-4,104$ & 80.54 & 1.574 & 1.683 & - & - & 35.13 & 60.72 & - & - & 2.65 & - & - \\
\hline $10-3,120$ & 98.20 & 1.576 & 1.748 & - & - & 33.05 & 56.84 & - & - & 2.75 & - & - \\
\hline $10-4,87$ & 99.37 & 1.584 & 1.719 & - & - & 34.13 & 58.57 & - & - & 2.72 & - & - \\
\hline $11-2,74$ & 105.74 & 1.581 & 1.759 & - & - & 31.63 & 56.18 & - & - & 2.78 & - & - \\
\hline $14-1,45$ & 151.45 & - & - & 1.714 & 1.779 & 33.38 & - & 58.87 & 54.99 & - & - & - \\
\hline $14-2,67$ & 153.17 & 1.697 & - & 1.747 & 1.823 & 15.88 & - & 56.90 & 52.36 & - & 2.96 & 3.09 \\
\hline $16-2,147$ & 182.47 & 1.690 & - & - & - & - & - & - & - & - & - & - - \\
\hline $17-1,94$ & 189.94 & 1.720 & - & 1.775 & 1.820 & 30.55 & - & 55.22 & 52.54 & - & 3.05 & 3.13 \\
\hline $17-4,148$ & 194.98 & 1.749 & - & 1.761 & 1.864 & 32.51 & - & 56.06 & 49.91 & - & 3.08 & 3.26 \\
\hline $18-2,21$ & 209.71 & 1.691 & - & 1.771 & 1.811 & 29.70 & - & 55.46 & 53.07 & - & 2.99 & 3.06 \\
\hline $18-3,48$ & 211.48 & 1.720 & - & 1.813 & 1.881 & 29.06 & - & 52.96 & 48.90 & - & 3.12 & 3.24 \\
\hline $19-1,92$ & 237.42 & 1.684 & - & 1.684 & - & 26.90 & - & 49.61 & - & - & 3.15 & - \\
\hline $21-1,137$ & 284.37 & 1.852 & - & 1.854 & 1.924 & 23.82 & - & 50.51 & 46.33 & - & 3.43 & 3.56 \\
\hline $21-2,98$ & 286.48 & 1.827 & - & 1.865 & 1.923 & 25.82 & - & 49.85 & 46.39 & - & 3.41 & 3.51 \\
\hline $21-3,100$ & 288.00 & 1.740 & - & 1.854 & 1.918 & 25.95 & - & 50.51 & 46.69 & - & 3.23 & 3.34 \\
\hline $21-0,0$ & 293.50 & 4.191 & - & - & 2.241 & - & - & - & 27.40 & - & - & 9.36 \\
\hline $22-1,148$ & 304.48 & 1.924 & - & 1.915 & 1.971 & 24.17 & - & 46.87 & 43.52 & - & 3.68 & 3.79 \\
\hline $22-3,4$ & 306.04 & 1.964 & - & 1.929 & 2.000 & 24.38 & - & 46.03 & 41.79 & - & 3.79 & 3.93 \\
\hline $22-5,148$ & 310.48 & 1.956 & - & 1.934 & 1.978 & 23.98 & - & 45.73 & 43.10 & - & 3.78 & 3.87 \\
\hline $23-1,3$ & 331.53 & 1.974 & - & 1.951 & 2.016 & 21.80 & - & 44.72 & 40.84 & - & 3.85 & 3.98 \\
\hline $23-4,148$ & 337.48 & 1.996 & - & - & - & - & - & - & - & - & $\therefore-$ & - \\
\hline $23-6,24$ & 339.24 & 2.112 & - & 2.046 & - & 18.95 & - & 39.04 & - & - & 4.32 & . - \\
\hline $24-1,53$ & 351.03 & 2.049 & - & 2.025 & 1.839 & - & - & 40.30 & 51.40 & - & 4.15 & 3.77 \\
\hline $24-3,11$ & 353.61 & 2.572 & - & 2.110 & 2.173 & - & - & 35.22 & 31.46 & - & 5.43 & 5.59 \\
\hline $24-5,140$ & 357.90 & 2.073 & - & 2.030 & 2.700 & - & - & 40.00 & - & - & 4.21 & 5.60 \\
\hline $24-6,105$ & 359.05 & 2.970 & - & 2.257 & 2.216 & - & - & 26.45 & 28.90 & - & 6.70 & 6.58 \\
\hline $25-1,25$ & 369.75 & 3.251 & - & 2.190 & 1.950 & - & - & 30.45 & 44.78 & - & 7.12 & 6.34 \\
\hline $25-2,20$ & 371.20 & 3.191 & - & - & - & - & - & - & - & - & - & - \\
\hline $25-2,110$ & 372.10 & 3.388 & - & - & - & - & - & - & - & - & - & - \\
\hline $25-2,122$ & 372.22 & 3.332 & - & - & - & - & - & - & - & - & - & - \\
\hline $26-1,3$ & 379.03 & 1.950 & - & 2.014 & 2.055 & 20.78 & - & 40.96 & 38.51 & - & 3.93 & 4.01 \\
\hline $26-3,147$ & 383.47 & 2.088 & - & 2.043 & 2.079 & - & - & 39.22 & 37.07 & - & 4.27 & 4.34 \\
\hline $26-6,35$ & 386.85 & 2.063 & - & 2.145 & 2.167 & 15.64 & - & 33.13 & 31.82 & - & 4.43 & 4.47 \\
\hline $28-1,8$ & 436.08 & 2.135 & - & 2.117 & 2.144 & 16.04 & - & 34.81 & 33.19 & - & 4.52 & 4.58 \\
\hline $28-3,5$ & 439.05 & 2.120 & - & 2.143 & 2.124 & 15.78 & - & 33.25 & 34.39 & - & 4.54 & 4.50 \\
\hline $29-1,3$ & 464.53 & 1.813 & - & 1.993 & 2.022 & 20.30 & - & 42.21 & 40.48 & - & 3.61 & 3.67 \\
\hline $29-2,4$ & 466.04 & 1.846 & - & 1.991 & 2.027 & 20.83 & - & 42.33 & 40.18 & - & 3.68 & 3.74 \\
\hline $30-2,31$ & 474.31 & 2.014 & - & 2.047 & 2.065 & 19.45 & - & 36.99 & 37.91 & - & 4.12 & 4.16 \\
\hline $30-4,148$ & 478.48 & 2.048 & - & 1.961 & 2.006 & 22.61 & - & 44.12 & 41.43 & - & 4.02 & 4.11 \\
\hline $30-6,148$ & 481.48 & 1.947 & - & 2.006 & 2.004 & 21.27 & - & 41.43 & 39.16 & - & 3.91 & 3.98 \\
\hline $31-1,132$ & 494.32 & 1.761 & - & 2.036 & 2.069 & 20.34 & - & 39.64 & 37.67 & - & 3.59 & 3.64 \\
\hline $31-4,25$ & 497.75 & 1.962 & - & 2.137 & 2.170 & 15.88 & - & 33.61 & 31.64 & - & 4.19 & 4.26 \\
\hline $32-1,97$ & 503.47 & 1.967 & - & 2.016 & 2.107 & 19.56 & - & 40.84 & 35.40 & - & 3.97 & 4.14 \\
\hline $32-3,11$ & 505.61 & 2.050 & - & 2.058 & 2.115 & 18.54 & - & 38.33 & 34.93 & - & 4.22 & 4.34 \\
\hline $32-5,143$ & 509.50 & 1.914 & - & 2.152 & 2.180 & 16.54 & - & 32.72 & 31.04 & - & 4.12 & 4.17 \\
\hline $33-1,23$ & 521.73 & 1.875 & - & 2.114 & 2.164 & 17.80 & - & 34.99 & 32.00 & - & 3.96 & 4.06 \\
\hline $33-3,127$ & 525.77 & 2.011 & - & 2.134 & 2.168 & - & - & 33.79 & 31.76 & - & 4.29 & 4.36 \\
\hline $33-6,92$ & 529.92 & 2.146 & - & 1.965 & 2.180 & 16.18 & - & 43.88 & 31.04 & - & 4.22 & 4.68 \\
\hline $34-1,102$ & 551.02 & 1.994 & - & 2.062 & 2.111 & 17.46 & - & 38.09 & 35.16 & - & 4.11 & 4.21 \\
\hline $34-3,148$ & 554.48 & 1.895 & - & 2.112 & 2.165 & 16.14 & - & 35.10 & 31.94 & - & 4.00 & 4.10 \\
\hline $34-6,23$ & 557.73 & 1.935 & - & 2.136 & 2.189 & 16.55 & - & 33.67 & 30.51 & - & 4.13 & 4.24 \\
\hline $35-1,148$ & 579.98 & 1.816 & - & 2.064 & 2.125 & 18.26 & - & 37.97 & 34.33 & - & 3.75 & 3.86 \\
\hline $35-3,148$ & 532.98 & 2.010 & - & 2.010 & 2.165 & 18.37 & - & 35.76 & 31.94 & - & 4.22 & 4.35 \\
\hline $35-5,123$ & 585.73 & 1.920 & - & 2.036 & 2.093 & 19.51 & - & 39.64 & 36.24 & - & 3.91 & 4.02 \\
\hline $36-1,128$ & 608.28 & 1.798 & - & 2.109 & 2.155 & 17.43 & - & 35.28 & 32.54 & - & 3.79 & 3.87 \\
\hline $36-3,148$ & 611.48 & 1.952 & - & 2.173 & 2.236 & 14.85 & - & 31.46 & 27.70 & - & 4.24 & 4.36 \\
\hline $36-5,122$ & 614.22 & 1.889 & - & 2.115 & 2.170 & 16.53 & - & 34.93 & 31.64 & - & 4.00 & 4.10 \\
\hline $39-1,148$ & 684.48 & 2.274 & - & 2.308 & 2.327 & 10.62 & - & 23.40 & 22.27 & - & 5.25 & 5.29 \\
\hline $40-1,147$ & 693.97 & 2.226 & - & 2.246 & 2.276 & 10.58 & - & 27.10 & 25.31 & - & 5.00 & 5.07 \\
\hline $40-3,148$ & 696.98 & 2.027 & - & 2.139 & 2.202 & 15.15 & - & 33.49 & 29.73 & - & 4.34 & 4.46 \\
\hline $40-6,45$ & 700.45 & 2.228 & - & - & 2.250 & 12.91 & - & - & 26.87 & - & - & 5.01 \\
\hline $41-1,148$ & 704.48 & 2.040 & - & 2.144 & 2.201 & 14.65 & - & 33.19 & 29.79 & - & 4.37 & 4.49 \\
\hline $41-3,148$ & 707.48 & 2.310 & - & 2.203 & 2.237 & 14.45 & - & 29.67 & 27.64 & - & 5.09 & 5.17 \\
\hline $41-5,147$ & 710.47 & 2.183 & - & 2.038 & 2.185 & 13.24 & - & 39.52 & 30.75 & - & 4.45 & 4.77 \\
\hline
\end{tabular}


TABLE 4 - Continued

\begin{tabular}{|c|c|c|c|c|c|c|c|c|c|c|c|c|}
\hline \multirow{2}{*}{$\begin{array}{l}\text { Sample } \\
\text { (Interval } \\
\text { in } \mathrm{cm} \text { ) }\end{array}$} & \multirow{2}{*}{$\begin{array}{l}\text { Depth } \\
\text { (m) }\end{array}$} & \multirow{2}{*}{$\begin{array}{l}\text { Velocity } \\
(\mathrm{km} / \mathrm{sec})\end{array}$} & \multicolumn{3}{|c|}{ Density $(\mathrm{g} / \mathrm{cc})$} & \multirow{2}{*}{$\begin{array}{l}\text { Water } \\
\text { (Wt \%) }\end{array}$} & \multicolumn{3}{|c|}{ Porosity (\%) } & \multicolumn{3}{|c|}{ A coustic Impedance } \\
\hline & & & $\mathrm{S}$ & I & G & & $\mathrm{S}$ & I & G & $\mathrm{S}$ & I & G \\
\hline $42-1,148$ & 712.98 & 2.281 & - & 2.247 & 2.284 & 11.49 & - & 27.04 & 24.84 & - & 5.13 & 5.21 \\
\hline $42-3,147$ & 715.97 & 2.148 & - & 2.173 & 2.214 & 14.50 & - & 31.46 & 29.01 & - & 4.67 & 4.76 \\
\hline $42-5,145$ & 718.95 & 2.046 & - & 2.105 & 2.028 & 17.72 & - & 35.52 & 40.12 & - & 4.31 & 4.15 \\
\hline $43-1,146$ & 722.46 & 2.234 & - & 2.060 & 2.104 & 18.18 & - & 38.21 & 35.58 & - & 4.60 & 4.70 \\
\hline $43-3,148$ & 725.48 & 1.848 & - & 2.152 & 2.456 & 15.13 & - & 32.72 & 14.57 & - & 3.98 & 4.54 \\
\hline $43-6,61$ & 729.11 & 2.527 & - & 2.313 & 2.197 & 10.80 & - & 23.10 & 30.03 & - & 5.84 & 5.55 \\
\hline $44-1,147$ & 731.97 & 2.355 & - & 2.320 & 2.316 & 10.14 & - & 22.69 & 22.93 & - & 5.46 & 5.45 \\
\hline $44-3,148$ & 734.98 & 2.465 & - & 2.333 & 2.323 & 10.76 & - & 21.91 & 22.51 & - & 5.75 & 5.73 \\
\hline $44-6,148$ & 739.48 & 2.355 & - & 2.330 & 2.310 & 10.57 & - & 22.09 & 23.28 & - & 5.49 & 5.44 \\
\hline $45-1,117$ & 741.17 & 2.266 & - & 2.283 & 2.307 & 11.95 & - & 24.90 & 23.46 & - & 5.17 & 5.23 \\
\hline $46-1,149$ & 744.49 & 2.405 & - & 2.336 & 2.332 & 9.86 & - & 21.73 & 21.97 & - & 5.62 & 5.61 \\
\hline $46-4,141$ & 746.91 & 2.366 & - & 2.309 & 2.311 & 10.28 & - & 23.34 & 23.22 & - & 5.46 & 5.47 \\
\hline $46-0,0$ & 749.50 & 2.479 & - & 2.369 & & 12.31 & - & 19.76 & - & - & 5.87 & - \\
\hline $47-1,148$ & 750.98 & 2.394 & - & 2.320 & 2.309 & 9.97 & - & 22.69 & 23.34 & - & 5.55 & 5.53 \\
\hline $47-3,148$ & 753.98 & 2.623 & - & 2.367 & 2.379 & 8.77 & - & 19.88 & 19.16 & - & 6.21 & 6.24 \\
\hline $47-6,147$ & 758.47 & 2.170 & - & 2.160 & 2.197 & 14.78 & - & 32.24 & 30.03 & - & 4.69 & 4.77 \\
\hline $48-1,147$ & 760.47 & 2.264 & - & 2.149 & 2.168 & 15.42 & - & 32.90 & 31.76 & - & 4.87 & 4.91 \\
\hline $48-3,148$ & 763.48 & 2.698 & - & 2.365 & 2.372 & 9.43 & - & 20.00 & 19.58 & - & 6.38 & 6.40 \\
\hline $48-6,142$ & 767.92 & 2.528 & - & 2.301 & 2.260 & 11.66 & - & 23.82 & 26.27 & - & 5.82 & 5.71 \\
\hline $49-1,22$ & 768.72 & 2.305 & - & - & 2.339 & 11.22 & - & - & 21.55 & - & - & 5.39 \\
\hline $49-1,148$ & 769.98 & 2.442 & - & 2.325 & - & - & - & 22.39 & - & - & 5.68 & - \\
\hline $49-3,149$ & 772.99 & 2.259 & - & 2.210 & 2.192 & 10.96 & - & 29.25 & 30.33 & - & 4.99 & 4.95 \\
\hline $50-1,148$ & 779.48 & 2.541 & - & 2.309 & 2.309 & 9.03 & - & 23.34 & 23.34 & - & 5.87 & 5.87 \\
\hline $50-3,143$ & 782.43 & 2.548 & - & 2.266 & 2.320 & 11.05 & - & 25.91 & 22.69 & - & 5.77 & 5.91 \\
\hline $50-6,149$ & 786.99 & 2.379 & - & 2.273 & 2.203 & 13.42 & - & 25.49 & 29.67 & - & 5.41 & 5.24 \\
\hline $51-1,54$ & 788.04 & 2.496 & - & 2.285 & 2.321 & 10.65 & - & 24.78 & 22.63 & - & 5.70 & 5.79 \\
\hline $51-3,147$ & 791.97 & 2.551 & - & 2.193 & 2.229 & 12.52 & - & 30.27 & 28.12 & - & 5.59 & 5.69 \\
\hline $51-6,148$ & 796.48 & 2.231 & - & 2.092 & 2.135 & - & - & 36.30 & 33.73 & - & 4.67 & 4.76 \\
\hline
\end{tabular}

NOTE: $\mathrm{S}=$ syringe technique, $\mathrm{I}=$ immersion technique, $\mathrm{G}=$ GRAPE.

Samples of the breccia have also been tested on shore (Carlson and Christensen, this volume).

The third unit in the sequence grades from limestones at the top to chalk, and extends to a depth of 674 meters. It appears to show a slight negative velocity gradient, which may reflect the gradation. No gradient is apparent, however, in the density or water content data. Absence of a compaction trend, particularly in water content, suggests that water may be trapped by the overlying dolostone and breccia.

Absence of strong gradients also distinguishes the lowest unit we reached, a limestone. Though the maximum velocities for this unit increase with depth, and the average density is slightly higher than that of the unit above, density in the unit itself does not increase markedly, nor does the water content decrease. Thus, the chalk-limestone unit at the top of the sequence provides the only significant evidence of compaction at Site 357.

\section{BIOSTRATIGRAPHIC SUMMARY}

A nearly complete Tertiary sequence containing abundant calcareous fossils, but few siliceous ones, was recovered at this site. The section lacks the lowermost Danian, the base of the Eocene and the top of the Paleocene, the upper Eocene/lower Oligocene, parts of the middle to upper Miocene, part of the upper Pliocene, and the uppermost Pliocene/lower Pleistocene.

A Cretaceous section ranging from upper Maestrichtian to lowermost Santonian was also retrieved. Parts of the middle Maestrichtian seem to be missing; the section below, except for dissolution levels in the Campanian, appears to be complete.

The upper and lower Pleistocene and parts of the upper and lower Pliocene were recovered. The absence of upper Pliocene-lower Pleistocene sediments has been recorded in several piston cores from the Rio Grande Rise (see Berggren, this volume). The lower Pliocene has been zoned by nannofossils, but also by foraminifers (Berggren, this volume according to his 1973 P1 zonation).

The Miocene/Pliocene boundary occurs in Core 3, but neither the nannofossil nor the foraminifer data are absolutely conclusive. The upper Miocene nannofossils are overgrown, and some key species are missing. The foraminifers in the upper Miocene have been assigned to one new zone by Berggren (this volume). Rather than a long middle Miocene hiatus, such as that found at other South Atlantic sites, a hiatus covering part of the upper middle and lower upper Miocene occurs at Site 357, between Sections 5-4 and 5-5. Berggren (this volume) recognizes another hiatus between N 7-8 and $\mathrm{N} 11$ in the lower middle Miocene, between Sections 64 and 6-5.

A thick lower Miocene sequence parallels that found at nearby Site 22 (Leg 3$)$ and at Site 356 . Using the foraminifers it is possible to locate both the high latitude zones of Jenkins (1971) and Kennett (1973).

The extensive upper Oligocene at this site contains both abundant calcareous and siliceous fossils. The calcareous fossils are generally better preserved in both the lower Miocene and upper Oligocene sequences, 
where radiolarians are also present. Radiolarians are never as abundant again below the Oligocene, although they occur throughout the lower and most of the middle Eocene at this site. A minor amount of chert in parts of the Eocene suggests that many of the radiolarians originally present have been dissolved.

Only the upper part of the lower Eocene occurs at this site, since a hiatus spans most of the lower Eocene and upper Paleocene. The middle and lower Paleocene down to the Danian is represented, but the lowermost Danian and the Tertiary/Cretaceous boundary lay between Cores 30 and 31 in a 9.5 -meter uncored interval.

As at Site 356, the nannofossils are better preserved in the Paleocene than in the Eocene. The foraminifers are not particularly well preserved in either series at Site 357.

The Cretaceous sequence recovered at Site 357 spans from the upper Maestrichtian to the lowermost Santonian. Most of the Maestrichtian, except for some middle Maestrichtian, was recovered, as were presumably complete sections of Campanian and Santonian. In Cores 35-38, of Campanian age, all planktonic foraminifers have been dissolved, leaving a residue of benthic foraminifers and some nannofossils. An age for these cores was derived from both calcareous nannofossils and benthic foraminifers.

The Santonian was particularly long at this site, and Core 50, at the bottom of this hole, is assumed to belong in the lowermost Santonian, although the calcareous microfossils are very poorly preserved.

\section{Paleoecology}

Some information concerning water depths, circulation patterns of water masses in the South Atlantic, and the chemistry and effects of interstitial waters on sediment can be derived from the calcareous and siliceous microfossil faunas at Site 357.

\section{Depths}

The indicator assemblages of benthic foraminifers suggest the following depths for this portion of the Rio Grande Rise:

\section{Recent >2000 meters \\ Oligocene-Miocene 1500-2000 meters \\ Paleocene-Eocene 1000-1500 meters \\ Cretaceous $\sim 1000$ meters}

Depth estimates for the Recent through the late Eocene are based on total benthic assemblages, planktonic/benthic ratios, and the depth-indicator species Uvigerina spinulosa and Uvigerina rippensis. In addition, the upper Oligocene benthic assemblages in Hatton-Rockall Basin (DSDP Leg 12, Site 116, Core 23) with estimated depositional depths of $\sim 1800$ meters, resembled assemblages at Site 357.

Assemblages of Paleocene benthic foraminifers on Rockall, however, resemble Paleocene Gulf Coast Midway Group shelf depth foraminifers (Berggren, 1972). This is not so at Site 357, where Paleocene benthic species are scarce, indicative of deeper waters, and do not resemble the classic Midway faunas. In fact, they bear closer affinity to the slope depth faunas of benthic foraminifers from the Paleocene of Jordan or the Blake Plateau.

Cretaceous benthic faunas bear the characteristic "deep" water association Gavelinella, Aragonia, and Nuttalides. "Deep" in the Cretaceous of this site suggests depths of close to 1000 meters.

From the examination of the ostracodes of Site 357 and comparison of these with the faunas of Sites 21A and 22 (Leg 3), the depths seem greater than 1000 meters from the Danian to the present time; the faunas are totally blind (indicating depths probably greater than $800 \mathrm{~m}$ ), with generally large specimens and low diversity (Benson, this volume).

\section{Temperature and Circulation}

The Plio-Pleistocene of Site 357 contains subtropical faunas of foraminifers and nannofossils. However, the presence of $S$. dehiscens, a typical latitudinally restricted tropical index species, may indicate warmer water periods in the Pleistocene at this site. By analogy, its predecessors $S$. seminulina and/or $S$. praedehiscens may prove to be climatic indices for the Miocene and Pliocene at this latitude.

For Miocene sequences it was necessary to apply a high-latitude zonation of foraminifers. Indeed, many typical New Zealand species, including the useful $G$. conomiozea-G. miozea series, are present at this site. But the coccoliths at this time are still zoned according to the standard low- and mid-latitude scheme of Martini (1971).

The radiolarians in the lower Miocene include orosphaerids and collosphaerids, indicating tropical to subtropical surface waters. The lower Miocene planktonic foraminifers include predominately cooler water elements.

Several explanations for this apparent paradox are possible: (a) mixing of water masses, tropical and highlatitude, at this intermediate latitude; (b) increased vigor of the North Atlantic Deep Water with cooler temperatures, in addition to the more southerly extent of a vigorous surface tropical gyre; and (c) differing definitions of "subtropical" and "high latitude" among specialists in different subdisciplines.

A major change in deep water circulation flowing from the North Atlantic into the South Atlantic occurred during the early-middle Miocene. This change should be reflected in the faunas at Site 357, since the North Atlantic Deep Water is known to flow this far south in the South Atlantic. What other effects this event may have had at Site 357 remains to be seen. It does not seem likely that it is responsible for the mixed radiolarian and foraminifer climatic indications discussed above.

The Oligocene discoaster/chiasmolith ratio indicates a "cool" Oligocene, as do the radiolarian and foraminifer faunas. The "cooler" foraminifers became essentially latitudinally ubiquitous at this time, as the ocean waters cooled (Shackleton and Kennett, 1975, and Boersma and Shackleton, this volume).

At mid-latitudes in the Eocene, planktonic foraminifer faunas characteristically contain several species of keeled globorotalids. But faunas with reduced numbers of these globorotalids apparently 
characterize the later early Eocene at these latitudes, and the loss of these keeled forms has been related to cooling of South Atlantic waters after accumulation of the first land ice on Antarctica (Premoli-Silva and Haq, in preparation). Just such a change occurs in the faunas of planktonic foraminifers at Site 357: the middle Eocene contains a diverse assemblage of keeled globorotalids, whereas early Eocene faunas contain only one globorotalid species.

The hiatus representing the upper Paleocene to lower Eocene at this site and at Site 356 is anomalous with respect to other sections of the Atlantic, where corresponding faunas of planktonic foraminifers are diverse and common (Premoli-Silva and $\mathrm{Haq}$, in preparation).

\section{Foraminifers}

Cores drilled at Site 357 on the northern flank of the Rio Grande Rise, at a water depth of 2086 meters, contain a stratigraphic sequence ranging from upper Pleistocene through Upper Cretaceous.

\section{Pleistocene}

The top core of the section was a water core which contained only a thimbleful of sediment. This sediment contains a well-preserved, diverse upper Pleistocene assemblage of planktonic foraminifers, deep bathyal benthic foraminifers, and several species of pteropods. The planktonic assemblage is dominated by subtropical forms, but the presence of the tropical species Sphaeroidinella dehiscens suggests that the fauna existed during a warmer episode in the late Pleistocene.

On the basis of Globigerinoides ruber (pink), this assemblage is assessed to be of late Pleistocene age: the presence of Sphaeroidinella excavata places it in Zone N23.

\section{Pliocene}

Pliocene sediments were recovered from Core 1 to Core 3, Section 5. Although there is still dispute over the location of the Pliocene/Miocene boundary, Globoquadrina dehiscens ranges up into Core 3, Section 5 , so the boundary is placed somewhere in that section. For detailed discussion of the Miocene-Pliocene faunas from this site, see Berggren (this volume).

In Cores 1 and 2, later Pliocene foraminifers are present; these include Globorotalia miocenica, $G$. multicamerata, and G. tosaensis. The bottom of Core 2 and the top of Core 3 contain G. puncticulata as well as members of the $G$. margaritae complex. Sphaeroidinellopsis spp. occur together with members of the $G$. crassacrotoensis-crotoensis plexus. Thus, a fairly full Pliocene section occurs below the hiatus separating the upper Pleistocene from the upper (though not the uppermost) Pliocene.

\section{Miocene}

An extensive Miocene sequence was retrieved in Cores 3 through 15 . Present in these faunas are the high latitude indicator species of the G. miozea-conomiozea group, the Globigerina woodi group, the Globorotalia fohsi, and Orbulina-Praeorublina sequence of fossils. Berggren (this volume) has zoned this sequence and compared it to sequences in piston cores from the Rio Grande Rise. A hiatus spans the upper middle-lower upper Miocene, although the lower Miocene appears to be complete. The fossils are generally well preserved, although a great deal of mixing, reworking, and redeposition of material has occurred.

In addition to the standard zonation of Berggren (this volume), the 1973 zones of Kennett can be recognized, along with the high latitude lower Miocene zones of Jenkins (1971). The table below depicts these higher latitude zones.

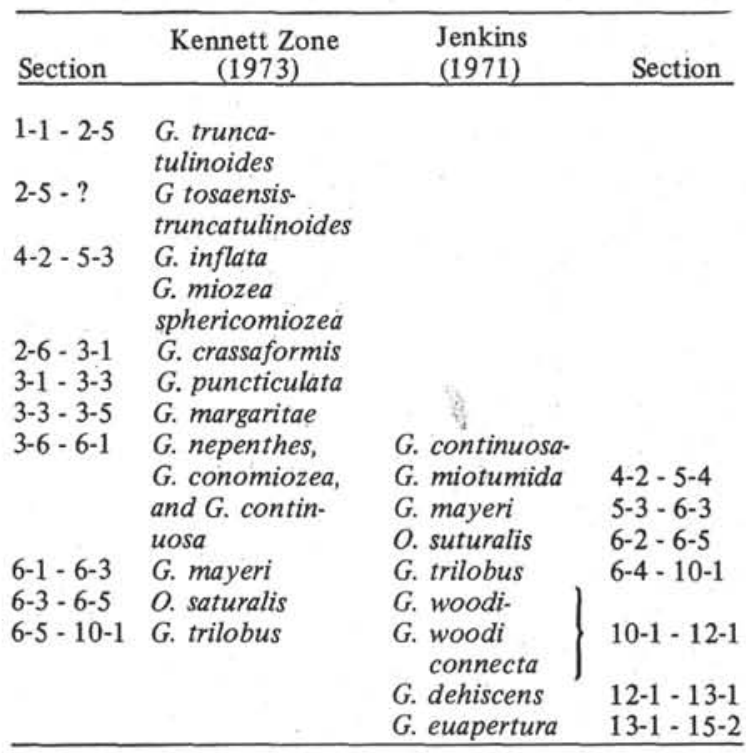

The lower Miocene sequence is long and the faunas fairly monotonous. Preservation is markedly improved in those samples containing radiolarians. Faunas characteristically contain high percentages of subtropical to high latitude species.

Throughout the Miocene the benthic foraminifers are somewhat scarce, but indicate bathyal depths. For example, Uvigerina spinulosa occurs through most of the Miocene, and indicates depths from 1500 to over 2000 meters.

\section{Oligocene}

Cores 16 through 19 contain sediments of Oligocene age. These Oligocene faunas also contain both higher and mid-latitude species, but the Oligocene is subdivided according to a low-latitude zonation. The upper Oligocene Globigerina angulisuturalis Zone, indicated by the presence of the nominate taxon and the absence of Globorotalia (T.) opima opima, is well represented at this site. In appearance, $G$. angulisuturalis resembles the compact high-latitude forms more than the more open and flaring lower latitude ones.

The upper Oligocene Zone P20 and the lower Oligocene Zone P19 are represented in Cores 18 and 19. However, the foraminifers are strongly corroded, bullae are often completely dissolved, and the faunas are not diverse. G. euapertura, a higher latitude species, occurs with $G$. ampliapertura, Chilogumbelina cubensis, $G$. ouachitaensis, G. tripartita, Globigerina praebulloides, and Globorotalia (T.) opima nana. 
The benthic foraminifers in Oligocene samples are particularly well preserved and diverse, and indicate bathyal depths.

\section{Eocene}

The Eocene sequence at this site is more extensive than that at Site 356; in their lower portions, however, they both record similar sequences of faunal events (see range charts, Boersma, this volume). In addition, both record supposed simultaneous incursions of radiolarian- and diatom-rich sediments; the longer section at Site 357 records a longer episode of incursions of siliceous sediments than at Site 356. Mixing and dissolution make zonation of parts of this Eocene sequence difficult.

Core 20 contains both upper and middle Eocene fossils. The top of the core containing $G$. (T.) cerroazulensis, P. mexicana, G. index, and G. barri, as well as the higher latitude species $G$. angiporoides, is assigned to the upper Eocene, Zone P16. Dissolution in some samples has been intense, leaving highly reduced faunas. For example, Sample $20-1,138 \mathrm{~cm}$ is essentially an ooze of Globigerinatheka spp., and resembles upper Eocene faunas from higher latitudes, as the upper Eocene at Site 277, Leg 29.

The lower sections from Core 20 belong to the middle Eocene, as indicated in the fauna containing $G$. (M.) lehneri, $T$. pseudotopilensis, $G$. index, and $G$. kugleri. Zones P13 through P11 occur in Cores 21 through 26. In general, preservation is not good; there is a high degree of dissolution and recrystallization, and faunas are reduced in diversity. Radiolarians occur in abundance first in Core 26, where the preservation becomes markedly worse; preservation remains moderate to poor throughout the Eocene sequence.

The older Eocene faunas contain $A$. densa, $A$. wilcoxensis, A. coalingensis, Hantkenina aragonensis, $G$. turgida, and $G$. boweri. Keeled globorotalids are rare, and globigerinids and acaraninids dominate the faunas.

Benthic foraminifers in this upper to middle Eocene sequence are common, fairly well preserved, and indicative of bathyal depths. Changes in benthic diversity, faunas, and planktonic/benthic ratios are discussed with respect to paleotemperature (in Boersma and in Boersma and Shackelton, this volume).

A hiatus occurs below Core 26. Cores 27-28 contain fossils from the lower Eocene Zones P7-P8. Keeled globorotalids are still not abundant, but both $G$. $(M$.) subbotina and primitive $G$. $(M$.) aragonensis are present in these samples, along with numerous acaraninids and a few small globigerinids. The first bullate species occur in Core 27, but bullae are not common until the middle Eocene, where many species are abundant.

Typical benthic species in this section include Nuttalides, Osangularia, Gyroidina, Stilostomella, and Uvigerina.

\section{Paleocene}

Only Cores 29 and 30 contain sediments of Paleocene age. Core 29, containing the index species $G$. (M.) pusilla, $G$. (M.) conicotruncana, $G$. (M.) velascoensis, and $G$. ( $P$.) ehrenbergi, belongs to the upper Paleocene Zone P3. Thus, the uppermost Paleocene Zones P4-P5 and the lowermost Eocene Zone P6 are not preserved at this site.

The lower Paleocene Zones P2 and P1 are represented in Core 30, although Zone P1 is not complete. The top of Core 30 contains G. uncinata and other typical Danian planktonic species, and the lower sections contain lower Danian fauna, including $G$. (T.) pseudobulloides, G. daubjergensis, and Woodringina hornerstownensis. The lowermost Danian is not preserved at this site.

Benthic foraminifers are particularly scarce. The genera Nuttalides and Gyroidina are most common. Nuttalides truempyi is generally found in deeper marine sections, and a Nuttalides-Gyroidinoides-dominant fauna generally represents slope depths, so the Paleocene sediment at this site could have been deposited at about 1000 meters.

\section{Cretaceous}

Faunas of late Maestrichtian through Santonian age occur in Cores 31 through 51. The Cretaceous zones and their index fossils are listed in the table which follows. Although late Campanian planktonic foraminifers are not present, nannofossils of this age occur in Core 36.

\begin{tabular}{|c|c|c|c|}
\hline Core & Sub Stage & Index Fossils & Zone \\
\hline $30-33$ & Upper Maestrichtian & $\begin{array}{l}\text { A. mayaroensis } \\
\text { R. fructicosa } \\
\text { G. contusa }\end{array}$ & A. mayaroensis \\
\hline 34 & Unzoned & & \\
\hline 35 & Lower Maestrichtian & $\begin{array}{l}\text { G. tricarinata } \\
\text { P. costulata } \\
\text { G. fornicata }\end{array}$ & G. tricarinata \\
\hline $36-39$ & Unzoned & & \\
\hline $40-47$ & Upper Santonian & $\begin{array}{l}\text { G. concavata } \\
\text { carinata } \\
\text { H. reussi } \\
\text { G. asperus }\end{array}$ & \\
\hline $47-51$ & Lower Santonian & $\begin{array}{l}\text { G. concavata } \\
\text { concavata } \\
G . \text { sinuosa } \\
\text { G. coronata } \\
\text { G. renzi }\end{array}$ & \\
\hline
\end{tabular}

Most of the fossils are not well preserved, particularly in Cores 34-50. In Cores 35-38, the planktonic species have been dissolved, leaving only benthic foraminifers, which are strongly corroded. The benthic assemblages are diverse, and contain the deepwater species of Aragonia, Nuttalinella, Gyroidinoides, Nodosarella, Dorothia, and Quadromorphina (Sliter, this volume). The assemblage is considered to be of upper slope depths. Samples from Cores 40 to 48 , however, contain benthic forms from shallower depths, including Bolivinoides, miliolids, worn echinoids, and Inoceramus prisms. Many of these fossils are considered to have been redeposited from the shelf down the slope (see Sliter, this volume). According to Sliter, the site may have sunk from mid-slope depths in the Santonian to bathyal depths $(1000 \mathrm{~m})$ by the end of the Cretaceous.

Globotruncana elevata first occurs in the core-catcher sample of Core 41 , but is rare throughout the rest of the 
Campanian, owing to dissolution. Both zones of the Santonian are well represented at this site. Although preservation is generally poor, $G$. concavata carinata is present from Core 47 through Core 42, and defines the upper part of the Santonian. The lower Santonian $G$. concavata concavata Zone is very long at this site, but the presence of $R$. pilula, G. asper, and $G$. fornicata at the bottom of this hole locates it still in the Santonian.

As Premoli-Silva and Boersma (this volume) point out, the outstanding feature of this Cretaceous section is the unusual degree of reworking and slumping; in consequence, faunal boundaries are often only tentatively placed, and faunas are known to be mixed, particularly in the Campanian and the Maestrichtian.

\section{Calcareous Nannofossils}

Calcareous nannofossils of Pleistocene to Santonian age are common in most of the cores recovered at this site. Preservation of the nannofossils is, with a few exceptions, moderately good in the Cenozoic and moderate to poor in the Upper Cretaceous marly limestones in which the hole bottomed. Figure 13 summarizes the coccolith zones found at this site. The distribution of coccolith species appears in tables in Perch-Nielsen (this volume).

\section{Pleistocene (Core 1)}

Assemblages of early Pleistocene age occur in the upper part of Core 1. They are dominated by small Prinsiaceae, and also contain some reworked Pliocene and Eocene coccoliths. In the uppermost three sections of Core 1, Gephyrocapsa oceanica and Pseudoemiliania lacunosa occur together, as is typical for the upper part of the P. lacunosa Zone (NN 19) of Martini (1971). A single discoaster occurs in Sample 356-1-4, $70 \mathrm{~cm}$, and is considered to be reworked; the sample thus still belongs to the $P$. lacunosa Zone. Upper Pleistocene foraminifers present in a "water-core" that must have reached bottom indicate that the upper Pleistocene is also present at this site, although we found no coccolith assemblages of this age.

\section{Pliocene (Cores 1 and 2)}

Discoaster brouweri and $D$. pentaradiatus are both rare in Sections 5 and 6 of Core 1, which we here consider to represent Zones NN 18 and 17. They become more common in Sample 1, CC, where $D$. surculus, and thus the zone of this name, is also recognized (NN 16). Only at the top of Core 2 do discoasters become more frequent, indicating that climatic conditions here were better earlier in the late Pliocene. Reticulofenestra pseudoumbilica is very infrequent, and considered to be reworked down to Core 2, Section 4. It becomes more common in Section 2-5, and abundant in Sample 2, CC, where the earliest Ceratolithus rugosus occurs. The first occurrence of $C$. rugosus is usually in the lower Pliocene, just above the Miocene/Pliocene boundary. $C$. acutus, the first birefringent ceratolith, also occurs in Sample 2, CC. It has been reported by Gartner as Ceratolithus sp. from the base of the Pliocene, and overlaps with $C$. rugosus in the upper part of its range.

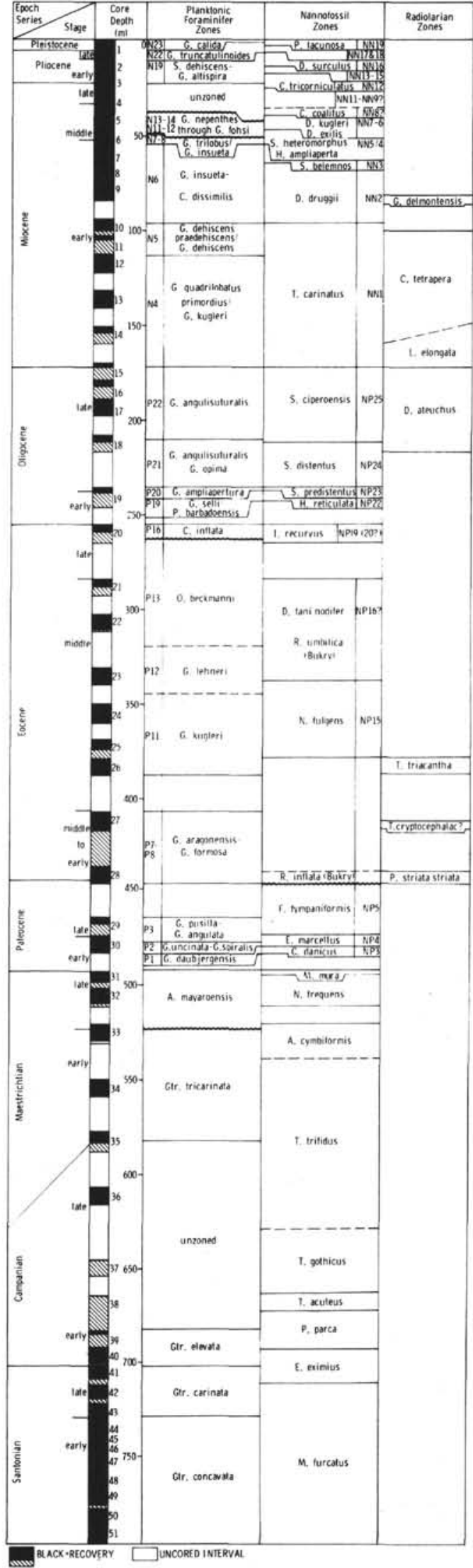

Figure 13. Biostratigraphic summary, Site 357. 


\section{Miocene (Cores 3-15)}

Common discoasters, usually heavily overgrown, and reworked Oligocene/Eocene coccoliths in small amounts characterize the Miocene coccolith assemblages at Site 357 .

The nonbirefringent ceratoliths Amaurolithus amplificus, A. delicatus, A. primus, and A. tricorniculatus indicate upper Miocene sediments. Absence of birefringent ceratoliths suggests that the uppermost sample from Core 3, Sample 3-1, $70 \mathrm{~cm}$, does not represent the very top of the Miocene. The first occurrence of ceratoliths is in Sample 3-5, $135 \mathrm{~cm}$. It is usually in the Discoaster quinqueramus Zone (NN 11). Because of the overgrowth on discoasters, it is almost impossible to distinguish $D$. quinqueramus from other 5-rayed discoasters, such as $D$. pentaradiatus, and thus to recognize the $D$. quinqueramus Zone properly. $D$. surculus usually has its first occurrence near that of $D$. quinqueramus; we found it down to Sample 3-5, $135 \mathrm{~cm}$, the same depth as ceratoliths. From here downward, no age-diagnostic nannofossils were found until Sample 5$2,135 \mathrm{~cm}$, where the last Coccolithus miopelagicus occurs, indicating an early middle Miocene age for this sample. The last Cyclicargolithus floridanus was found in Sample 5-5, $70 \mathrm{~cm}$, indicating the lower part of the Discoaster exilis Zone to be present. Sphenolithus heteromorphus has its last occurrence in Sample 6-2, 74 $\mathrm{cm}$, and overlaps with $S$. belemnos in Sample 6-6, 70 $\mathrm{cm}$. No Helicopontosphaera ampliaperta are present to distinguish the $S$. belemnos and $H$. ampliaperta zones. The occurrence of $D$. druggi down to Sample 10-2 65 $\mathrm{cm}$, and the last occurrence of $S$. ciperoensis in Sample 15 , CC, reflect further events in the earliest Miocene and latest Oligocene. Dictyococcites bisecta has its last occurrence in Sample 14, CC, Reticulofenestra abisecta in Sample 10, CC.

Thus the coccolith zones represented here indicate some upper Miocene, the lower middle Miocene, and the lower Miocene. We could not establish zones for parts of the lower upper Miocene and of the upper middle Miocene; these parts may be partly missing.

\section{Oligocene (Cores 15 to 19)}

All but the lowermost zones of the standard coccolith zonation of the Oligocene are represented at this site. The marker nannoliths $S$. ciperoensis, $S$. distentus, and $S$. predistentus are usually scarce, but $S$. predistentus becomes common in a few samples. In the lowermost Miocene samples, Zygrhablithus bijugatus is already present in small numbers; in the Oligocene and the Eocene it is a common, sometimes even dominant, part of the coccolith assemblage. Chiasmolithus altus, a form typical of high-latitude Oligocene assemblages, is present in most samples but is usually rare. Discoaster deflandrei, the only consistently occurring discoaster, is rare to common, Helicopontosphaera euphratis is present consistently but sparsely. Representatives of the family Braarudosphaeraceae occur in small numbers in some samples, and include Braarudosphaera sp. and Micrantholithus sp. The low discoaster/chiasmolith ratio indicates relatively cool conditions at this site during the Oligocene (but see discussion in PerchNielsen, this volume).

\section{Eocene (Cores 20 to 28)}

The incomplete upper and middle Eocene sequence recovered contains common but only poorly preserved to moderately well preserved coccoliths. Z. bijugatus is, as in the Oligocene, an important constituent of the assemblage. Isthmolithus recurvus, together with Discoaster barbadiensis and D. saipanensis, characterize the youngest Eocene in Core 20. Sphenolithus pseudoradians, a not very reliable marker nannolith of the uppermost Eocene, was not found. From Core 21 through Core 23, Chiasmolithus solitus occurs, but no Nannotetrina. This interval, where Discoaster tani is common to rare was assigned to the $D$. tani nodifer Zone (NP 16), although some D. tani occur infrequently below Core 23. Nannotetrina $\mathrm{sp}$. and $N$. fulgens, heavily overgrown, occur from Sample 23, CC, to Sample $28-6,66 \mathrm{~cm}$. The very bottom of the corecatcher of Core 28 contains about $2 \mathrm{~cm}$ of sediment with an upper Paleocene (NP 5) assemblage. Since we drilled for 19 meters below cored interval 28 before retrieving Core 28 , it is likely that Sample $28, \mathrm{CC}$, comes from somewhere in the drilled interval, and that the hiatus occurs in this interval rather than at the bottom of cored interval 28 .

\section{Paleocene (Sample 28, CC, bottom and Cores 29 and 30)}

We encountered only a short Paleocene sequence at this site. It includes the lower upper Paleocene zone of Fasciculithus tympaniformis (NP 5) and the Danian Ellipsolithus macellus (NP 4) and Chiasmolithus danicus (NP 3) zones. No lowermost Danian was cored; the Danian/Maestrichtian contact occurs in the interval between Cores 30 and 31 . We did find, however, a lump of Danian sediment (NP 2/3) loose on top of Core 31 . The Paleocene coccolith assemblages are better preserved than the Eocene assemblages, as noted before in the thick Paleocene sequence at Site 356 on the São Paulo Plateau.

\section{Upper Cretaceous (Cores 31 to 51)}

The coccolith assemblages in the Upper Cretaceous sequence at Site 357 closely resemble those from Site 356 . Coccoliths are abundant to few, and preservation deteriorates down section. Micula mura, which indicates a latest Maestrichtian age for the youngest Cretaceous present, occurs down to Sample 31-3, 40 $\mathrm{cm}$. Nephrolithus frequens, which usually has its first occurrence slightly below $M$. mura at the few places where they occur together, is present in very small quantities down to Sample 32, CC. Lithraphidites quadratus, which usually occurs before $N$. frequens, here also has its first occurrence in Sample 32, CC, so the zone of this name cannot be distinguished. Core 33 contains no marker forms other than Arkhangelskiella cymbiformis, which ranges from the upper Campanian through the Maestrichtian. Tetralithus trifidus and $T$. gothicus have their last occurrences together in Sample $34-1,70 \mathrm{~cm}$, where Broinsonia parca is also present. The T. trifidus Zone thus extends from here down to Sample $36-6,70 \mathrm{~cm}$, where $T$. trifidus first occurs. $T$. gothicus and the zone of this name extend from Section 36-6 to Sample 37, CC, where the last specimens of Eiffellithus eximius were also found. Although the last 
Marthasterites furcatus occurs in Sample $40-2,70 \mathrm{~cm}$, the first Broinsonia parca occurs in Sample 41, CC. The two species thus overlap at this site; they did not overlap at Site 356 on the São Paulo Plateau. M. furcatus is rare to few in most samples down to Sample $51, \mathrm{CC}$, where the hole bottomed in the Santonian. It is, however, often heavily overgrown and hardly recognizable, and in some samples seems to be missing. Generally, diversity diminishes downhole, except in a few samples, where preservation of the coccoliths is also better.

Kamptnerius magnificus is occasionally rare in the Santonian and the Campanian, rare in most of the Maestrichtian, and absent in the uppermost part of the upper Maestrichtian. Lucianorhabdus cayeuxi is common only from the lower Campanian downward.

\section{Radiolaria}

Radiolarians occur as a measurable constituent only in the coarse fractions of Cores 9 through 28 (except Cores 21 through 25-see below), corresponding to lithologic Unit 2, a foraminifer-nannofossil ooze which grades to limestone. Traces of radiolarians occur in Cores 1-8, and except for a few very infrequent occurrences in Cores 40 and 50, Cores 29 to 51 are barren of siliceous microfossils. The presence of chert in the sediment of Cores 21-24, and the absence of siliceous microfossils in this interval, indicate that remobilization and migration of silica from adjacent sediment was involved in formation of the chert. Core 25 contained a volcanic breccia and dolostone, except for the lower $40 \mathrm{~cm}$, which consisted of limestone containing radiolarians. In none of the samples examined are the radiolarians abundant in the total coarse fraction, but they are the dominant constituent of the noncalcareous fraction. Diversity is very low and preservation very poor in the top and bottom parts of Unit 2, as well as in the sediment above the cherts (Cores 19-20). The remaining sediments of interval 2 contain assemblages of moderate diversity and moderate to good preservation.

Assemblages of the lower Miocene C. tetrapera Zone occur in Cores 10-13. The presence of Dorcadospyris ateuchus, Lychnocanoma bipes, and Cyclampterium (?) pegetrum indicates the lower part of the zone. It is difficult to assign Core 14 definitively to either the $C$. tetrapera or the L. elongata Zone; Core 15 belongs to the latter. Cyrtocapsella cornuta, C. tetrapera, and D. simplex in the samples still indicate a lower Miocene age; this is substantiated by the foraminifers and calcareous nannofossil zonation. Sponge spicules, orosphaerid fragments, and collosphaerids occur commonly in all samples examined, which indicates tropical to subtropical surface waters.

Assemblages of the Dorcadospyris ateuchus Zone are in Cores 16 to 18. In Core 18, abundance, preservation, and diversity of the radiolarians decline. Only fragments occur in Cores 19-20, and they are absent or extremely rare in Cores 21-23. As mentioned previously, this is the interval in which cherts occur. Thinsection examination of the cherts reveals the common presence of radiolarians in advanced stages of dissolution.
From Core 25 to Core 28, lower middle Eocene to upper lower Eocene assemblages of the zones of Thyrosocyrtis triacantha (Cores 25, 26), Theocotyle cryptocephala and Phormocyrtis striata striata (Core 28), and Cryptocephala (Core 27), occur. Below Core 28 the sediment is barren of radiolarians, except for very infrequent occurrences in Cores 40 and 50 .

The scarcity of siliceous microfossils in the sediment of this site can be explained as a consequence of the following factors:

1) Low productivity of siliceous phytoplankton and microzooplankton in the surface waters in this region through time. This is difficult to evaluate, especially since siliceous microfossils are abundant in upper middle Eocene deposits elsewhere in the Atlantic, but are apparently absent at this site.

2) Relatively shallow depth of this site through time with respect to the $C C D$, resulting in masking of the siliceous component of the biogenic sediment by the large volumetric input of calcareous microfossils. In order to retrieve an adequate sample of radiolarians, large amounts of sediment (up to $50 \mathrm{cc}$ ) from the core catchers were processed.

3) Undersaturation of the interstitial water with respect to silica, resulting in dissolution and migration of silica. Evidcence for this is the domination of all the assemblages examined by heavy walled, robust species. This is strikingly demonstrated in the top part of the section, where orosphaerid spines and mesh fragments provide the first evidence of radiolarians downhole in Core 8; orosphaerid fragments and sponge spicules are abundant in all Miocene samples examined.

The most likely cause for the relatively sparse occurrences of radiolarians is found in a cause and effect relationship between factors 2 and 3 .

\section{SEDIMENT ACCUMULATION RATES}

Figure 14 summarizes the sediment accumulation history at Site 357 and at Leg 3, Sites 21 and 22 on the Rio Grande Rise. The fairly complete, predominately calcareous pelagic sequence, ranging from the Pleistocene to the Santonian, was cored continuously at the top in order to recover as complete a Neogene sequence as possible. Below Core 12 (lower Miocene) coring was semicontinuous until near the bottom of the hole, where continuous coring was necessary for operational reasons and for attempting to core the sediment/basement contact.

Accumulation was rapid during the Santonian, probably more than $2 \mathrm{~cm} / 1000 \mathrm{yr}$, and slower during the Campanian. A mid-Campanian hiatus may be present, but cannot be clearly established. The apparent slow accumulation in the Campanian may be an artifact of the long duration here assigned to the Campanian, or the result of apparent dissolution of foraminifers in the Campanian deposit. In the late Campanian and early Maestrichtian, the accumulation of calcareous pelagic sediments continued at the high rate of about $3 \mathrm{~cm} / 1000 \mathrm{yr}$. According to the foraminifer data, part of the middle Maestrichtian is missing. Sedimentation was slow, on the order of 0.5 $\mathrm{cm} / 1000 \mathrm{yr}$ during the latest Maestrichtian, the earliest 


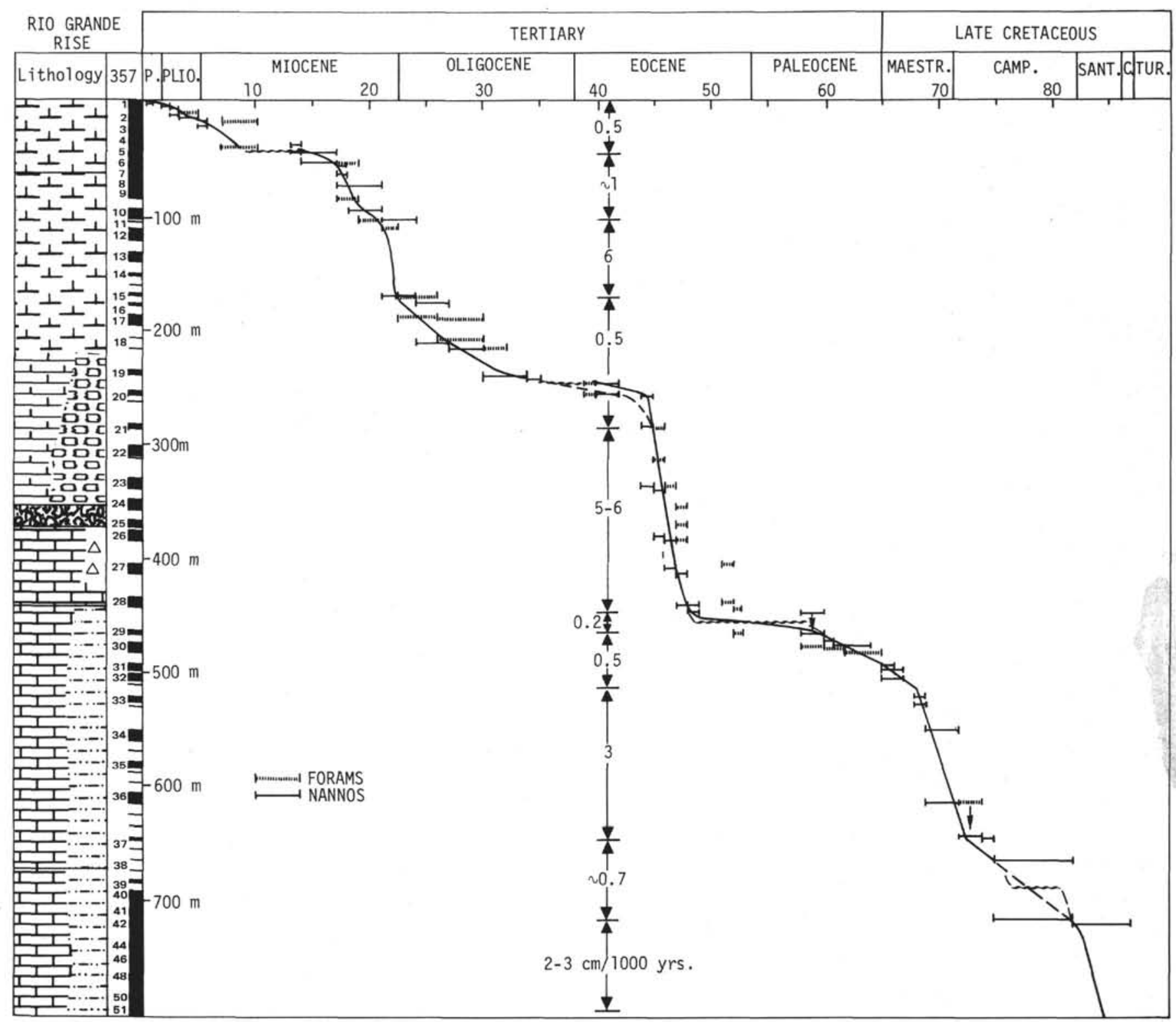

Figure 14. Sediment accumulation history, Site 357.

Paleocene, and across the Cretaceous/Tertiary boundary, which lies between Cores 31 and 30. If a hiatus is present at this boundary at this site, it is very short. There are no signs of a very shallow CCD, as proposed by Worsley (1974), during the latest Cretaceous and the earliest Tertiary at this site.

A hiatus through most of the late Paleocene and early Eocene is reflected in Core 28. Since the bottom part of Sample 28, CC, where the only Paleocene assemblage occurs, probably comes from somewhere in the 19-meter drilled interval below the bottom of Core 28 proper, the hiatus is most likely in this uncored interval rather than at the bottom of cored interval 28 . If continuous accumulation is assumed instead of a hiatus, it would have occurred at the slow rate of about $0.2 \mathrm{~cm} / 1000 \mathrm{yr}$ from the late Paleocene ( $58 \mathrm{~m}$.y.B.P.) to the early/middle Eocene ( 49 m.y.B.P.). Nondeposition during all or part of this interval is evident in sequences at three other sites on this leg: 354 , 356 , and 358 .

Accumulation rates were very high, 5 to $6 \mathrm{~cm} / 1000$ $\mathrm{yr}$, for middle Eocene sediments, which also contain volcanic breccia probably transported from shallower parts of the rise. Upper Eocene sediments occur only in Core 20; Cores 15 to 20 contain a relatively complete middle through upper Oligocene sequence. There is some doubt about the depths at which Cores 20 and 21 were actually cut; i.e., at the bottom of the drilled interval, as intended and recorded, or inadvertently at the top of the interval drilled with the core barrel in place. In the latter case, the accumulation history would change from probably continuous accumulation, at a rate of about $0.5 \mathrm{~cm} / 1000 \mathrm{yr}$, from the middle Eocene through the Oligocene, to a somewhat higher rate before and after a hiatus across the Eocene/Oligocene boundary. A similar problem exists with Cores 19 
to 17 , drilling breccias in which it is not possible to assign exact depths to the individual core pieces.

For a short time in the early Miocene, accumulation was very rapid, about $6 \mathrm{~cm} / 1000 \mathrm{yr}$, then it slowed to about $1 \mathrm{~cm} / 1000 \mathrm{yr}$ later in the early Miocene. According to Berggren (this volume), a hiatus spans the late early Miocene to early middle Miocene, and possibly the late middle Miocene to middle late Miocene and early late Miocene to late Pliocene.

The sedimentary sequence recovered at Site 357 supplements the sequences previously recovered at Sites 21 and 22. Essentially, four periods of faster than "normal" pelagic accumulation and four periods of slower than "normal" calcareous pelagic accumulation occur at Site 357. Compared with Site 21, where Campanian sediment was reached at about 100 meters, the sequence at Site 357 is more complete, especially the Neogene. At Site 22, however, accumulation rates in the Oligocene and in the lower Miocene are about the same as at Site 357, and the rest of the Neogene is missing.

\section{CORRELATION OF REFLECTION PROFILES WITH DRILLING RESULTS}

Site 357, on the northern flank of Rio Grande Rise, was chosen on the basis of two R/V Vema profile records (V26, \#825, and V26, \#836). The Vema profiles (see Figure 4) were made for a site survey for Site 22, which was drilled during DSDP Leg 3 . The present site is approximately $30 \mathrm{~km}$ west of Site 22 .

The reference profiles as well as the approach profile display a reflector at approximately $0.8 \mathrm{sec}$, which, because of its character, appears to be igneous basement. On the basis of the depth of this reflector, we thought that crystalline basement would lie approximately 800 meters below the sediment-water interface.

Figure 15 includes a (reversed) tracing of the seismic profile (Figure 5) recorded while approaching Site 357. Three identifiable reflectors are present, at $0.24,0.38$ and $0.78 \mathrm{sec}$. These reflectors have been assigned numbers 1 through 3 , starting with the uppermost reflector. They can be mapped in the area around the site and through most of the area of Rio Grande Rise (see McDowell et al., this volume).

The measured seismic velocities in cores permit us to assign seismic velocities for intervals between these reflectors, and thus to calculate the subbottom depth for each reflector. The average interval velocities used here are as follows: $1.60 \mathrm{~km} / \mathrm{sec}$ between ocean bottom and reflector $1,1.75 \mathrm{~km} / \mathrm{sec}$ between reflector 1 and reflector 2 , and $2.14 \mathrm{~km} / \mathrm{sec}$ between reflectors 2 and 3 . These velocities suggest that the three reflectors occur at subbottom depths of 192, 315, and 742 meters, respectively.

The calculated depths for these reflectors correlate fairly well with abrupt changes in average seismic velocities for various segments of the sediment column (see Figure 12). The curve for acoustic impedance, however, (Figure 12), does not show the same breaks as the curve for average seismic velocities.

These reflectors are not related to changes in lithology. The sediment column drilled at Site 357 is composed almost entirely of pelagic calcareous material; the sediments are marly near the bottom of the hole. The reflectors seem to be related only to diagenetic changes in the sediments. These changes have occurred as a result of either overburden and chemical alteration or different rates of accumulation.

Reflector 1 appears to be related to a transition from ooze to chalk, and to a change in accumulation rate at 190 meters. Thin stringers of chert occur at approximately the same depth as the calculated depth of reflector 2 . Hence, this reflector may be related to the siliceous material in Unit 2 of the sediment column. Also, a change in accumulation rate is evident at $\sim 300$ meters; the calculated depth to reflector 2 is 315 meters.

Reflector 3, which was generally assumed to be crystalline basement, seems only to mark the top of the very well-indurated marly limestone of Unit 5. A change in accumulation rate is also apparent at 750 meters. We drilled another 50 meters beyond the calculated depth of reflector 3 to ensure that basement penetration not be missed because of slight error in measuring the depth to basement on profiler records, or because of minor experimental error in measuring sonic velocities of the sediments.

The volcanic breccia of Unit 3 does not register as a distinct reflector on the seismic profile. The seismic profile at the site shows alternate acoustically transparent and opaque zones. Possibly these zones can be related to homogeneous and inhomogeneous zones within the sediment column. Homogeneous regions of the sediment column should appear acoustically transparent on the seismic profile, whereas inhomogeneous zones should appear opaque.

\section{SUMMARY AND CONCLUSIONS}

We drilled and cored a 797-meter section of mainly pelagic biogenic sediment at Site 357 on the Rio Grande Rise. Coring was continuous in the top and bottom parts of the section-in the top to obtain as complete a Neogene sequence as possible, and in the bottom because of very slow penetration rates. The rest of the section was cored at close spacing. We did not reach igneous basement.

The general trend in the pelagic facies, from bottom to top of the section, is toward decreasing importance of the admixed terrigenous component, evidence of progressively more oxygenated open marine conditions, and decrease of the overall diagenesis. Thus, the Santonian marly limestones of Unit 5 have a relatively high terrigenous content, which decreases considerably in the transitional zone between Units 4 and 5. The source of the terrigenous sediments may have been the subaerially exposed Rio Grande Rise (discussed later) or, more probably, the South American mainland. The predominantly gray-green sediments indicate reducing conditions which allowed preservation of the many laminae present. The graygreen sediments alternate with brown (oxidized) sediments, and the percentage of laminated gray-green sediments decreases up the section. The same trend is apparent in an up-hole increase in burrowing in Units 5 and 4. Lamination is undisturbed at the base of Unit 5, and decreases up the section as burrows become more 

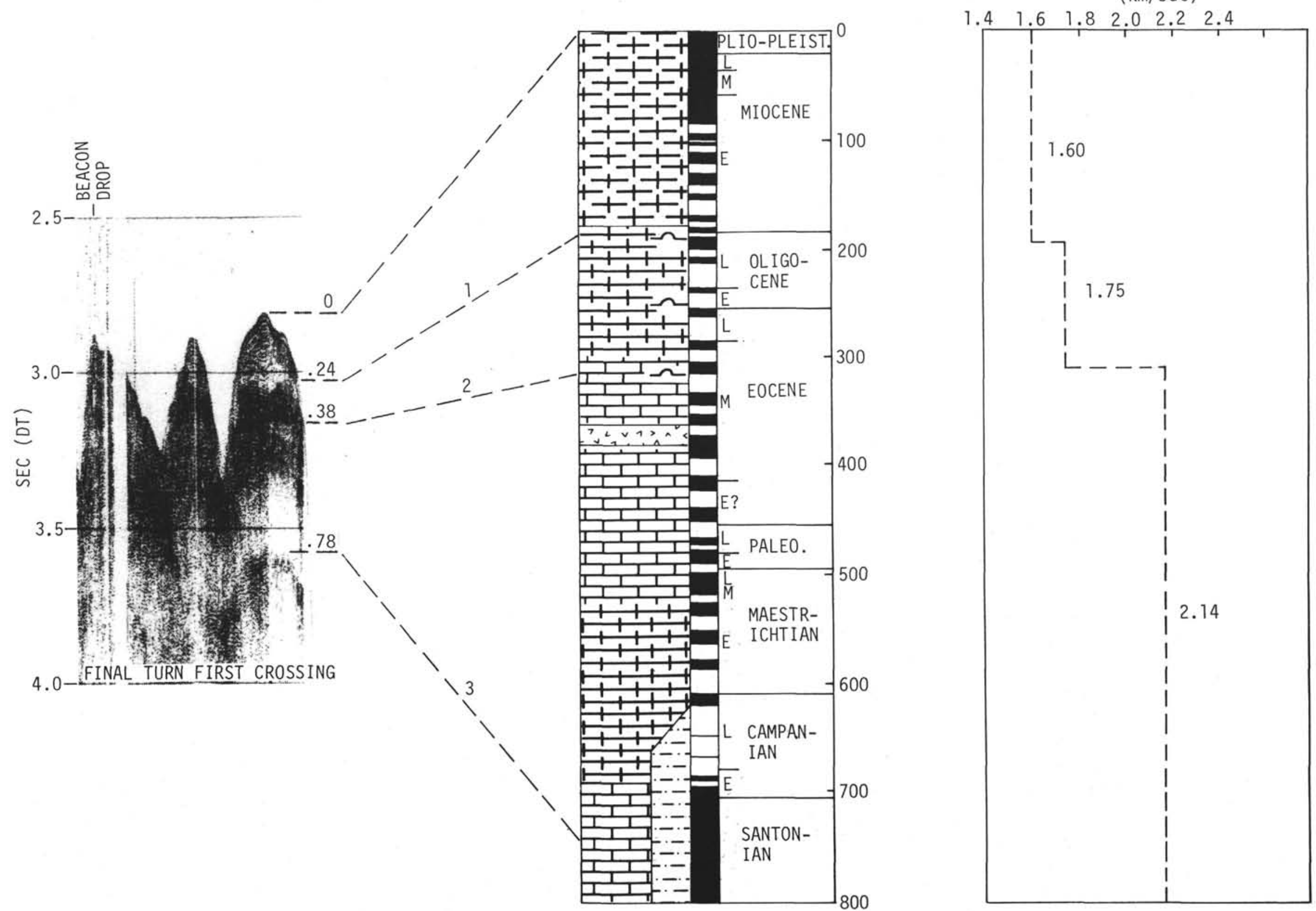

Figure 15. Correlation of the Site 357 approach profile with the lithostratigraphic section cored. Average interval velocities are based on Hamilton Frame measurements made aboard ship. 
prevalent. The upper Campanian through lowermost Eocene limestone and chalk of Unit 4 are differentiated from Unit 5 by color and lower overall terrigenous component, but the overall trends in Unit 5 continue into Unit 4; the lower part of Unit 4 is greener (again, in repeating cyclic patterns with brown).

The middle Eocene to lower Miocene nannofossilforaminifer oozes, chalks, and limestones show colors indicating oxidizing conditions, and have relatively little terrigenous component. Contribution of opaline fossils is significant only in this part of the section. The overlying lower Miocene through Pleistocene sediments are foraminifer-nannofossil oozes, with very little terrigenous material. The dominance of foraminifers, the pteropods in the uppermost part of the section, and the lack of dissolution or overgrowth of nannofossils, indicate little or no diagenesis.

Inferred hiatuses occur in the mid-Campanian, midMaestrichtian, at the Cretaceous/Tertiary boundary, the Paleocene/Eocene boundary, the Eocene/Oligocene boundary, and in the mid-Miocene. The significance of these hiatuses is discussed in another chapter (Supko and Perch-Nielsen, this volume). Benthic foraminifer assemblages indicate a general subsidence of the depositional site, from about 800 meters water depth in the Cretaceous to the present 2000 meters.

The microfossils lend evidence of changes in paleotemperature and paleocirculation at this site. Absence of keeled globorotalids in the upper lower Eocene, indicating cool water conditions, is typical of middle latitudes (Premoli-Silva, in preparation). Radiolarians, nannofossils, and foraminifers indicate a cold Oligocene; foraminifers and radiolarians show fluctuating temperatures in early Miocene.

Two findings in the Site 357 sediment sequence contribute to an understanding of the age and subsidence history of the Rio Grande Rise. The first is abundant Inoceramus fragments in the finely laminated Santonian sediments at the base of the section, presently $2.9 \mathrm{~km}$ below the sea surface; the second is the middle Eocene volcanic breccia.

That laminae of enclosing Santonian sediments are undisturbed and no shallow water biogenic elements other than Inoceramus are present; this indicates the shell fragments do not represent allochthonous material. Rather, they probably represent an epibenthic fauna indigenous to the site in Santonian times. Epibenthic Inoceramus seems to have been common in shallow to moderately deep environments in the late Cretaceous (Kauffmann, 1968; Thiede and Dinkelman, this volume), and for present purposes we may assume that the deposition site was in water about 300 to 500 meters deep in the early Santonian. Leg 3 results may be used to confirm this depth estimate, if we assume that Sites 21 and 357 are on the same piece of ocean crust subject to the same vertical movements. The basal core at Site 21 is a coquina containing shallow water components including red algae, indicating formation at or near sea level. The coquina is Campanian or older in age and was obtained from a present depth below sea level of $2.2 \mathrm{~km}$. Campanian sediments at Site 357 are at a present depth below sea level of $2.7 \mathrm{~km}$. The difference in depth indicates a Campanian paleodepth of deposition of about 500 meters at Site 357; paleodepth in the Santonian was probably about the same.

The middle Eocene volcanic breccia of Unit 3 may also indicate depth. It contains basalt pebbles, volcanic glass, and sedimentary components and clasts in a clayey matrix. The entire unit is size-graded, indicating it was probably emplaced from upslope in a single event. In addition to planktonic foraminifers, the biogenic component contains large benthic foraminifers, bivalve and gastropod shells of middle Eocene age and, very significantly, plates of red algae, which indicate a shallow water source. Although the basalt fragments are too altered for radioactive dating (see Fodor and Thiede, this volume), the biogenic materials indicate a downslope movement of mixed volcanic and biogenic material in large quantity in the middle Eocene. Since both the shallow water sediment components and the volcanic components are sizesorted in a similar way, they probably derived from a common provenance area in very shallow water (see further discussion in Supko and Perch-Nielsen, this volume). Deep pelagic facies of the same middle Eocene age underlie and overlie the allochthonous unit.

Igneous basement rocks have recently been dredged on the Rio Grande Rise from water depths of about 1000 meters (McDowell et al., this volume); they comprise weathered basalts, volcanic glass, and weathered lava. The basalts are alkalic as opposed to tholeiitic, and in bulk composition are similar to the volcanic materials of the islands of Tristan da Cunha, St. Helena, and Gough (Baker, 1973), as well as those of the Walvis Ridge (Hekinian, 1972). These similarities may support a view of the Rio Grande Rise as having once been a high volcanic island group, formed either at a "hot spot" on the spreading ridge (Wilson, 1965; Morgan, 1971) or in connection with movement along fracture zones (Francheteau and Le Pichon, 1972). The Santonian sediments at Site 357 provide a minimum age for the basement here. As discussed earlier, these sediments contain autochthounus Inoceramus, thought to indicate deposition at a depth of 300-500 meters. The Inoceramus-bearing beds lie at a present depth below sea level of close to 3000 meters. This and the badly weathered volcanic rocks dredged from water depths of 1000 meters indicate that in early Santonian time, portions of the Rio Grande Rise stood as a large volcanic island about 2000 meters above sea level, an elevation near the present elevation of Tristan $(2060 \mathrm{~m})$. Using dredge data from the eastern Atlantic (Pastouret and Goslin, 1974; Goslin et al., 1974), it can be argued that the Walvis Ridge, which many think is related to the Rio Grande Rise, had a minimum elevation of 1500 meters in Campanian time (75 m.y.B.P.).

Thiede (in preparation) has used the Site 357 shallow-water age indicators just mentioned (Santonian Inoceramus beds at approximately $300-500 \mathrm{~m}$ and middle Eocene breccia from about sea level), along with two other sea level-age data points, to determine a curve of submergence of former shoreline positions 
along the Rio Grande Rise. The additional data points are the presumably shallow water $(\leq 50 \mathrm{~m})$ coquina of Campanian age at the bottom of Hole 21, Leg 3 (Maxwell, Von Herzen, et al., 1970), at a present depth of $2.2 \mathrm{~km}$ below the water surface, and the shallowest (to account for possible downslope movement) of several dredgings of shallow water limestones (oölitic and so probably formed in depths $\leq 100 \mathrm{~m}$ ), reported from R/V Jean Charcot cruises (Melguen, 1973). This latter deposit is Oligocene in age and at present about 1000 meters below sea level. A plot of present depths (corrected for sediment load) of former shoreline positions as a function of age yields a subsidence curve for the Rio Grande Rise. This curve is similar to the age-depth relationship for ocean crust derived theoretically and shown empirically by Sclater et al. (1971), and supports the assumption that aseismic ridges on a volcanic foundation subside at about the same rate as normal surrounding ocean crust (see Vogt, 1974; Sclater and Fisher, 1974; Sclater et al., in press).

If subsidence of the rise follows the same age-depth relationship as oceanic crust, one may put limiting cases on the age and depth of basement at Site 357. This has been done by Thiede (in preparation), and much of the following discussion derives from his work.

First, we must assume that the dredged shallowest peaks of the rise represent the top of basement, as indicated by dredged basaltic rocks-i.e., that significant erosion had not occurred before submergence of the rise; this constraint requires that subsidence curves (Figure 16) be fitted through a present-time point about 650 meters below sea level, the shallowest recorded depth on the rise (Dietrich and Ulrich, 1968). This eliminates the possibility that basement is the same age as the lowest core and lies just below it (i.e., at $2900 \mathrm{~m}$ below present sea level), since this would be incompatible with the finding of Eocene oölitic limestone at a present depth of 1000 meters, as well as with the present depths of the peaks.

If the basement were indeed about the same age as the lowest core (early Santonian, $\sim 85$ m.y.B.P.), curve 1 indicates it would lie about 3600 meters below present sea level, or that 500 to 1000 meters of unsampled sediment lies between the lowest core and basement. A sufficient number of years must be allowed to account for this sediment accumulation.

The case for a very old crust (case 3), about 110 m.y.B.P., coincident with the earliest stages of Atlantic opening (Larson and Ladd, 1973), is contradicted by accumulation rate data. If the basement were that old (and now close to $4000 \mathrm{~m}$ below sea level), the accumulation rate in the Santonian $(\sim 30 \mathrm{~m} / \mathrm{m} . \mathrm{y}$.) would have exceeded the subsidence. Such was not the case, for despite this high accumulation rate, the Santonian water depth continued to increase, as indicated by the disappearance of shallow water fossils up-section. The intermediate case (curve 2, Figure 16) allows a high enough accumulation rate in the

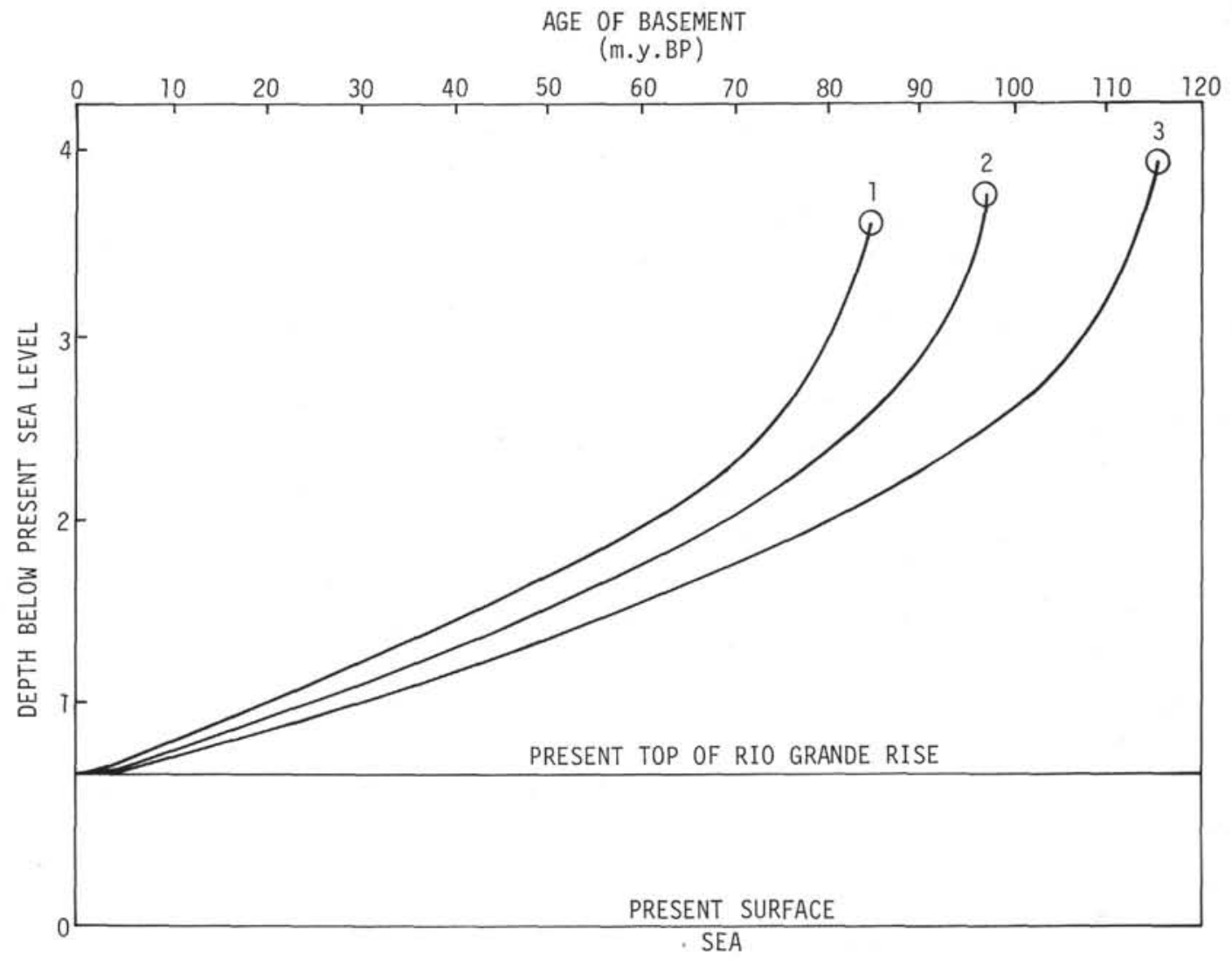

Figure 16. Basement subsidence curves which place constraints on the depth and age of crystalline basement under the Rio Grande Rise in the vicinity of Site 357. See text for explanation. 
TABLE 5

Depths of Deposition as a Function of Age, Site 357

\begin{tabular}{|c|c|c|c|c|c|c|c|}
\hline Stratigraphy & $\begin{array}{l}\text { Age of } \\
\text { Approx. } \\
\text { Midpoint } \\
\text { (m.y.) }\end{array}$ & $\begin{array}{l}\text { Present Depth } \\
\text { Below Water } \\
\text { Surface (m) }\end{array}$ & $\begin{array}{l}\text { Paleodepth (m } \\
\text { uncorrected for } \\
\text { sediment growth } \\
\text { and load) }\end{array}$ & $\begin{array}{l}\text { Sediment } \\
\text { Thickness }\end{array}$ & $\begin{array}{l}\text { Paleodepth of } \\
\text { Deposition (m) }\end{array}$ & $\begin{array}{c}\text { Hiatuses } \\
\text { (in m.y.B.P.) } \\
\text { (missing } \\
\text { sediment } \\
\text { in cumu- } \\
\text { lative m) }\end{array}$ & $\begin{array}{c}\text { Paleodepth of } \\
\text { Deposition (m) } \\
\text { Corrected for } \\
\text { Hiatuses }\end{array}$ \\
\hline L. Pliocene & 2 & 2101 & 2260 & 782 & 1869 & $(362)$ & 2050 \\
\hline E. Pliocene & 4 & 2102 & 2240 & 781 & 1850 & $(362)$ & 2031 \\
\hline L. Miocene & 8 & 2110 & 2200 & 733 & 1814 & (362) & 1993 \\
\hline M. Miocene & 12 & 2123 & 2140 & 760 & 1760 & (362) & 1941 \\
\hline E. Miocene & 19 & 2188 & 2020 & 695 & 1673 & $(362)$ & 1854 \\
\hline L. Oligocene & 28 & 2284 & 1880 & 599 & 1581 & $(362)$ & 1762 \\
\hline E. Oligocene & 35 & 2326 & 1770 & 557 & 1492 & (362) & 1673 \\
\hline L. Eocene & 41 & 2371 & 1640 & 512 & 1384 & (362) & 1565 \\
\hline M. Eocene & 46 & 2437 & 1560 & 446 & 1337 & $(362)$ & 1578 \\
\hline E. Eocene & 50 & 2529 & 1460 & 354 & 1283 & $50-56(362)$ & 1464 \\
\hline M. Paleocene & 59 & 2531 & 1300 & 352 & 1124 & (345) & 1296 \\
\hline Danian & 62 & 2566 & 1200 & 317 & 1041 & $62-67(345)$ & 1214 \\
\hline Maestrichtian & 68 & 2617 & 1000 & 266 & 867 & (195) & 965 \\
\hline Campanian & 79 & 2759 & 700 & 124 & 638 & $72.5-79(195)$ & 638 \\
\hline Santonian & 83 & 2821 & 500 & 62 & 469 & 0 & 469 \\
\hline
\end{tabular}

Santonian, and indicates a basement depth of about 3700 meters and an age of about 95 m.y.B.P. The age is in rough agreement with magnetic anomaly information for the surrounding basins and with age estimates from extrapolation of spreading rates; the necessary accumulation rate of about $6 \mathrm{~cm} / 1000 \mathrm{yr}$ for pre-Santonian sediments is high, but McDowell et al. (this volume) suggest that the layer below the deepest Site 357 core may represent a mixture of sediments and volcanics. Such layers are apparently indicated under other aseismic ridges (Houtz et al., in press), and may be inferred on the Ceará Rise (Site 354 report, this volume).

Assuming a deposition depth of 300-500 meters for the Santonian Inoceramus-bearing laminated sediments, one may use the Santonian-Pleistocene portion of curve 2 in Figure 16 to calculate depths of deposition as a function of time. Calculations by Thiede (in preparation) in Table 5 give depth corrected for isostatic effect of accumulated sediment load (Berger and von Rad, 1972) and for hiatuses. In the latter case, sediment is assumed to have accumulated during the hiatus and to have been erosionally removed just at the hiatal close, with isostatic rebound not accompanying the unloading.

A question left unresolved is whether the finegrained, laminated reduced sediments of Santonian age indicate a period of basinal stagnation for the northern South Atlantic, or whether the sediments were deposited while the deposition site was near a fluctuating open-ocean oxygen-minimum zone. On the one hand, similar sediments of like age have been reported from the São Paulo Plateau (Site 356 report, this volume) and Walvis Ridge (Bolli, Ryan, et al., 1975), and from various sites in the North Atlantic (Saunders et al., 1974). On the other hand, these sediments could have formed as the deposition area passed through and then out of the influence of a well-defined open oceanic oxygen-minimum zone of the type now known to exist in the northern Indian Ocean (Wyrtki, 1971). Similar fine-grained laminated facies have been found in areas where well-developed oxygen minima impinge upon continental margins (van Andel, 1964; von Stackelberg, 1972) and a depositional environment similar to that reflected in the Site 357 Santonian facies has been reported from intermediate water depths on the Ninetyeast Ridge (Site 254) in the eastern Indian Ocean (Davies, Luyendyk, et al., 1974).

\section{REFERENCES}

Baker, P.E., 1973. Islands of the South Atlantic. In Nairn, A.E.M. and Stehli, F.C. (Eds.), The ocean basins and margins, v. 1: The South Atlantic: (New York-London), Plenum Press, p. 493-553.

Berger, W. and von Rad, U., 1972. Cretaceous and Cenozoic sediments from the Atlantic Ocean. In Hayes, D.E., Pimm, A.C., et al., Initial Reports of the Deep Sea Drilling Project, Volume 14: Washington (U.S. Government Printing Office), p. 787-953.

Berggren, W.A., 1972. A Cenozoic time scale-some implications for regional geology and paleobiogeography: Lethaia, v. 5, p. 195-205.

Berggren, W.A., 1973. The Pliocene time scale: calibration of planktonic foraminiferal and calcareous nannofossil zones: Nature, v. 243, p. 391-397.

Bolli, H.M., Ryan, W.B.F., et al., 1975. Basins and margins of the eastern South Atlantic: Geotimes, v. 20, p. 22-24.

Davies, T.A., Luyendyk, B.P., 1974. Initial Reports of the Deep Sea Drilling Project, Volume 26: Washington (U.S. Government Printing Office).

Dietrich, G. and Ulrich, J., 1968. Atlas zur Ozeanographie: Mannheim (Bibliographisches Institut), p. 76.

Francheteau, J. and Le Pichon, X., 1972. Marginal fracture zones as structural framework of continental margins in South Atlantic Ocean: Am. Assoc. Petrol Geol. Bull., v. 56, p. 991-1007.

Goslin, J., Masele, J., Sibuet, J., and Le Pichon, X., 1974. Geophysical study of the easternmost Walvis Ridge, South Atlantic: morphology and shallow structure: Geol. Soc. Am. Bull., v. 85 , p. 619-632.

Hekinian, R., 1972. Volcanics from the Walvis Ridge: Nature, v. 239, p. 91-93. 
Houtz, R.E., Ludwig, W.J., Milliman, J.D., and Grow, J.A., in press. Structure of the northern Brazilian continental margin: Geol. Soc. Am. Bull.

Jenkins, D.G., 1971. New Zealand Cenozoic planktonic foraminifera: New Zealand Geol. Surv. Paleo. Bull. 42, p. 278.

Johnson, D.A., 1974. Initial Cruise Report, Chain 115, Leg 6. Woods Hole Oceanographic Inst., Tech. Rept. WHOI-7439 (unpublished manuscript), p. 51.

Kauffmann, E., 1968. The Upper Cretaceous Inoceramus of Puerto Rico: 4th Caribbean Geol. Conf. Trans. (Port-ofSpain, 1965), p. 203-218.

Kennett, J.P., 1973. Middle and late Cenozoic planktonic foraminiferal biostratigraphy of the southwest Pacific, DSDP Leg 21. In Burns, R.E., Andrews, J.E., et al., Initial Reports of the Deep Sea Drilling Project, Volume 21: Washington (U.S. Government Printing Office), p. 575640.

Ladd, J.W., 1974. South Atlantic sea floor spreading and Caribbean tectonics: Ph.D. thesis, Columbia University, New York.

Larson, R.L. and Ladd, J.W., 1973. Evidence for the opening of the South Atlantic in the Early Cretaceous: Nature, v. 246 , p. $209-212$.

Le Pichon, X., Saito, T., and Ewing, J., 1966. Mesozoic and Cenozoic sediments from Rio Grande Rise: Geol. Soc. Am., Ann. Mtg. (abstract), p. 121.

Leyden, R., Ludwig, W.J., and Ewing, M., 1971. Structure of the continental margin off Punta del Este, Uruguay and Rio de Janiero, Brazil. Am. Assoc. Petrol. Geol. Bull., v. 55 , p. $2161-2173$.

Martini, E., 1971. Standard Tertiary and Quaternary calcareous nannoplankton zonation. In Farinacci, A. (Ed.), Plankt. Conf. 2nd, Rome, 1970, Proc.: Roma (Tecnoscienzia), v. II, p. 739-785.

Maxwell, A.E., Von Herzen, R.P., et al., 1970. Initial Reports of the Deep Sea Drilling Project, Volume 3: Washington (U.S. Government Printing Office).

Melguen, M., 1973. Cruise Report Campagne "Geobresil": Centre Oceanologique de Bretagne, VNEXO, Brest, France (unpublished manuscript).

Melguen, M. and Thiede, J., 1974. Facies distribution and dissolution depths of surface sediment components from Vema Channel and Rio Grande Rise (Southwest Atlantic Ocean): Marine Geol., v. 17, p. 341-353.

Morgan, W.J., 1971. Convection plumes in the lower mantle: Nature, v. 230 , p. $42-43$.

Pastouret, L. and Goslin, J., 1974. Middle Cretaceous sediments from the eastern part of the Walvis Ridge: Nature, v. 248, p. 495-496.
Phleger, F.B. and Soutar, A., 1973. Production of benthic foraminifera in three East Pacific oxygen minima; Micropaleontology, v. 19, p. 110-115.

Saunders, J.B., Edgar, N.T., Donnelly, T.W., and Hay, W.W., 1973. Cruise synthesis. In Edgar, N.T., Saunders, J.B., et al., Initial Reports of the Deep Sea Drilling Project, Volume 15: Washington (U.S. Government Printing Office), p. 1077-1112.

Sclater, J.G. and Fisher, R.L., 1974. Evolution of the east central Indian Ocean, with emphasis on the tectonic setting of the Ninetyeast Ridge: Geol. Soc. Am. Bull., v. 85 , p. $683-702$.

Sclater, J.G., Anderson, R.N., and Bell, M.L., 1971. Elevation of ridges and evolution of the central eastern Pacific: J. Geophys. Res., v. 76, p. 7888-7915.

Sclater, J.G., Abbott, D., and Thiede, J., in press. Paleobathymetry and sediments of the Indian Ocean: Geol. Soc. Am. Mem.

Shackleton, N.J. and Kennett, J.P., 1975. Paleotemperature history of the Cenozoic and the initiation of Antarctic glaciation: Oxygen and carbon isotope analyses in DSDP Sites 277, 279, and 281. In Kennett, J.P., Houtz, R.E., et al., Initial Reports of the Deep Sea Drilling Project, Volume 29: Washington (U.S. Government Printing Office), p. 801-807.

Sliter, W.V., 1975. Foraminiferal life and residue assemblages from Cretaceous slope deposits: Geol. Soc. Am. Bull., v. 86 , p. $897-906$.

Thiede, J., in preparation. The subsidence of aseismic ridges: evidence from sediments on Rio Grande Rise (SW Atlantic Ocean).

van Andel, T.H., 1964. Recent marine sediments of the Gulf of California: Am. Assoc. Petrol. Geol. Mem., v. 3, p. 216-310.

Vogt, P.R., 1974. Volcano height and plate thickness: Earth. Planet. Sci. Lett., v. 23, p. 337-348.

von Stackelberg, U., 1972. Faziesuertezlung in Sedimenten der Indisch-Pakistanischen Kontinentalrandes (Arabisches Meer); "Meteor" Forsch.-Ergeb, v. C, p. 173.

Wilson, J.T., 1965. A new class of faults and their bearing on continental drift: Nature, v. 207, p. 343-347.

Worsley, T.R., 1974. The Cretaceous-Tertiary boundary event in the ocean. In Hay, W.W. (Ed.), Studies in paleooceanography, Spec. Pub. 20: Soc. Econ. Paleontol. Mineral., p. 94-125.

Wyrtki, K., 1971. Oceanographic Atlas of the international Indian Ocean expedition: Washington (U.S. Government Printing Office). 
APPENDIX A

Smear-slide Summary

\begin{tabular}{|c|c|c|c|c|c|c|c|c|c|c|c|c|c|c|c|c|c|c|c|c|c|c|c|}
\hline $\begin{array}{c}\text { Sample } \\
\text { (Interval in } \mathrm{cm} \text { ) }\end{array}$ & 䞤 & 站 & 总 & 晜 & 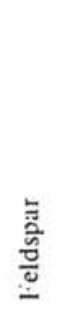 & $\stackrel{\Xi ّ}{\Sigma}$ & 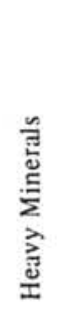 & $\vec{i}$ & 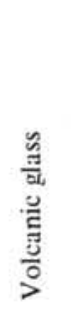 & 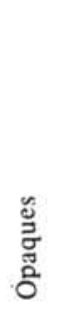 & 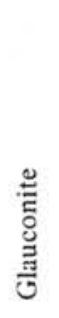 & $\stackrel{\stackrel{\Xi}{\Sigma}}{2}$ & 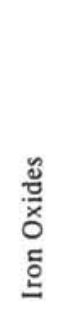 & 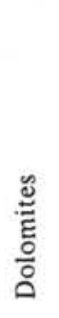 & 冚 & 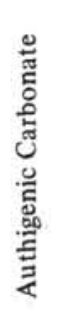 & 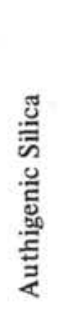 & 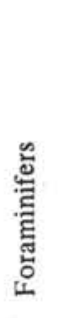 & 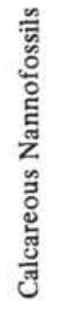 & 芯 & 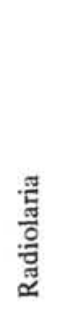 & 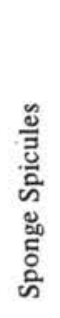 & Remarks \\
\hline $1-3,140$ & 40 & 20 & 40 & & & 1 & & 5 & & & & & & & & & & 44 & 50 & & & & \multirow{41}{*}{$\begin{array}{l}\text { black spot } \\
\text { burrow filling }\end{array}$} \\
\hline $2-3,140$ & 20 & 5 & 75 & & & 1 & & 10 & & & & & & & & & & 40 & 50 & & & & \\
\hline $3-3,140$ & 20 & 5 & 75 & & & $i$ & & 5 & & & & & & & & & & 35 & 60 & 1 & 1 & & \\
\hline $4-3,80$ & 20 & 5 & 75 & & & $i$ & & 5 & & & & & & & & & & 30 & 65 & & & & \\
\hline $5-4,78$ & 15 & 15 & 70 & & & 1 & & 5 & & & & & & & & & & 30 & 65 & & & & \\
\hline $6-5,90$ & 10 & 30 & 60 & & & & & 10 & & & & & & & & & & 30 & 60 & & & & \\
\hline $7-5,100$ & 10 & 40 & 50 & & & & & 5 & & & & & & & & & & 25 & 70 & & & & \\
\hline $8-4,100$ & 10 & 20 & 70 & & & & & 5 & & & & & & & & & & 15 & 80 & 1 & & & \\
\hline $9-3,100$ & 5 & 30 & 65 & & & & & 5 & & & & & & & & & & 10 & 85 & & & 1 & \\
\hline $10-2,100$ & 5 & 30 & 65 & & & & & 5 & & & & & & & & & & 15 & 65 & & & 5 & \\
\hline $11-2,100$ & 5 & 20 & 75 & & & & & 5 & & & & & & & & & & 10 & 75 & & 5 & 5 & \\
\hline $12-2,22$ & & 15 & 85 & & & & & & & & & 55 & & & & & & 5 & 40 & & & 1 & \\
\hline $12-3,100$ & 5 & 35 & 60 & & & & & 5 & 1 & & & & & & & & & 10 & 80 & & 1 & 5 & \\
\hline $13-3,70$ & 5 & 30 & 65 & & & & & 5 & 1 & & & & & & & 1 & & 10 & 80 & & 1 & 5 & \\
\hline $13-4,55$ & 5 & 30 & 65 & & & & & 5 & & & & & & & & 5 & & 10 & 75 & & 1 & 5 & \\
\hline $14-1,7$ & 20 & 40 & 40 & 1 & & & & 15 & & & & & & & & 15 & & 25 & 40 & & 1 & 5 & \\
\hline $14-2,86$ & 10 & 50 & 40 & & & & & 20 & & & & & & & & 15 & & 25 & 35 & & 1 & 5 & \\
\hline $15-2,105$ & & 40 & 60 & & & & & 5 & & & & & & & & 15 & & 15 & 55 & & 1 & 10 & \\
\hline $16-2,36$ & & 30 & 70 & & & & & 20 & & & & 1 & & & & 20 & & 20 & 35 & & 1 & 5 & \\
\hline $16-2,100$ & 20 & 50 & 30 & & & & & 10 & & & & & & & & 15 & & 25 & 45 & 1 & 1 & 5 & \\
\hline $17-1,90$ & 5 & 50 & 45 & & & & & 10 & 1 & & & & & & & 10 & & 30 & 40 & & 1 & 10 & \\
\hline $18-2,60$ & 5 & 45 & 50 & & & & & 15 & & & & & & & & 10 & 5 & 20 & 40 & & 1 & 10 & \\
\hline $18-3,6$ & & & & & & & & & & & & 100 & & & & & & & & & & & \\
\hline $19-2,88$ & 10 & 50 & 40 & & & 1 & & 10 & & & & 1 & & & & 20 & & 25 & 45 & & & & \\
\hline $20-1,120$ & 20 & 40 & 50 & & & & & 5 & & & & & & & & 25 & & 30 & 40 & & & & \\
\hline $20-2,100$ & 5 & 45 & 50 & 1 & & & & 10 & & & & & & & & 10 & & 30 & 50 & & & & \\
\hline $21-1,75$ & 5 & 25 & 70 & & & & & 5 & & & & & & & & 15 & & & 80 & & & & \\
\hline $21-3,30$ & 25 & 30 & 45 & & & & & 5 & & & & 1 & & & & 15 & 1 & 35 & 45 & & & & \\
\hline $21-3,80$ & 20 & 60 & 20 & & & & & & & & 1 & & & & 10 & 25 & & 25 & 40 & & & & \\
\hline $22-2,83$ & & 30 & 70 & & 1 & 1 & & 5 & & & 1 & & & 1 & 20 & 25 & & 20 & 30 & & & & \\
\hline $22-3,100$ & 5 & 40 & 55 & & & & & 5 & & & & & & & 5 & 20 & & 20 & 50 & & & & \\
\hline $22-3,118$ & 15 & 25 & 60 & & & 1 & & 5 & & & 1 & 1 & & & 1 & 40 & & 20 & 35 & & & & \\
\hline $23-2,62$ & 20 & 30 & 50 & 1 & 1 & & & & & & & & & & 1 & 90 & & & 5 & 1 & 1 & 2 & \\
\hline $23-4,62$ & 5 & 30 & 65 & 1 & & & & & & & & & & & & 80 & & 5 & 15 & & & & \\
\hline $24-1,35$ & 5 & 45 & 50 & & & & & 5 & 10 & & 10 & & & 5 & 5 & 20 & 15 & & 30 & & & & \\
\hline $24-3,92$ & & 50 & 50 & & & & & 20 & & 5 & & & & 10 & & 20 & 10 & 1 & 25 & 1 & 1 & 10 & \\
\hline $24-5,82$ & 5 & 50 & 45 & 5 & 5 & & 1 & & 5 & 1 & 5 & & & 5 & 1 & 5 & 10 & 10 & 20 & 1 & 20 & 10 & \\
\hline $24-5,87$ & & 20 & 80 & 1 & 1 & & & & 1 & 15 & 30 & & & 1 & 1 & 5 & 25 & 10 & & & 5 & 5 & \\
\hline $24-5,89$ & & 80 & 20. & & & & & 10 & & & & & & 75 & & 10 & & & & & & 5 & \\
\hline $24-5,94$ & & 80 & 20 & & & & & 5 & & & & & & 75 & & 10 & & & & & & 10 & \\
\hline $24-6,100$ & 10 & 85 & 5 & & & & & 5 & & & & & & 90 & & & & & & & & 5 & \\
\hline
\end{tabular}




\begin{tabular}{|c|c|c|c|c|c|c|c|c|c|c|c|c|c|c|c|c|c|c|c|c|c|c|c|}
\hline $\begin{array}{c}\text { Sample } \\
\text { (Interval in } \mathrm{cm} \text { ) }\end{array}$ & 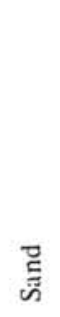 & $\overline{\bar{n}}$ & 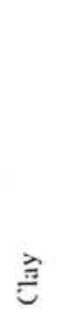 & 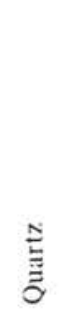 & 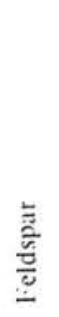 & 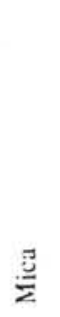 & 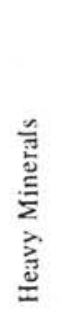 & 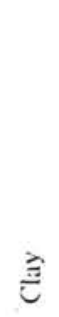 & 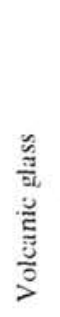 & $\begin{array}{l}\mathscr{g} \\
\tilde{\Xi} \\
\tilde{\Xi}\end{array}$ & 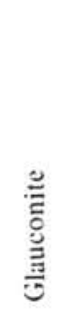 & $\stackrel{0}{2}$ & 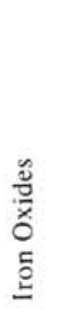 & 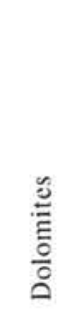 & $\begin{array}{l}\stackrel{\mathscr{\Xi}}{0} \\
\text { N }\end{array}$ & 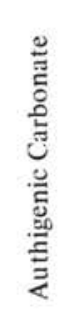 & 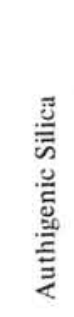 & 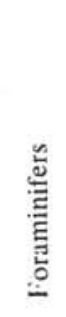 & 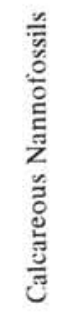 & 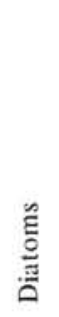 & $\begin{array}{l}\stackrel{\vec{Z}}{\vec{z}} \\
\stackrel{3}{\circ} \\
\stackrel{3}{\ddot{Z}}\end{array}$ & 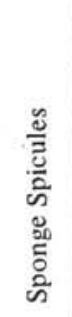 & Remarks \\
\hline $24-6,140$ & & 80 & 20 & & & & & & 5 & 5 & & & & 50 & & 20 & 20 & & & & & & \\
\hline $25-3$ & & & & & 1 & 2 & & & 45 & 1 & & & & & & 1 & 43 & 1 & 1 & & & & thin section \\
\hline $25-3,73$ & & 40 & 60 & & & & & 5 & 5 & & 15 & & & 30 & & 20 & 15 & 10 & & & & & large sediment clast \\
\hline $25-3,99$ & & & & & & & & 5 & 1 & & & & & 5 & 5 & 10 & 5 & 30 & 40 & 1 & & & sediment clast \\
\hline $25-3,110$ & 5 & 50 & 45 & & & & & & & & 5 & & & & 1 & 35 & 20 & 10 & 30 & & & & sediment clast \\
\hline $25-3,125$ & & & & & & & & 5 & 1 & & 1 & & & & 1 & 15 & 10 & 10 & 20 & 1 & 25 & 10 & \\
\hline $26-5,100$ & & 40 & 60 & 1 & & & & 10 & 1 & & & & & & 5 & 5 & & 30 & 50 & 1 & & & \\
\hline $27-6,72$ & 20 & 40 & 40 & 15 & & & & & 1 & & 1 & 1 & & & & 10 & 60 & 5 & 10 & & & & \\
\hline $27-4,60$ & 5 & 40 & 55 & & & & & 5 & & & & & & 1 & 5 & 5 & 20 & 30 & 35 & & & & \\
\hline $28-2,23$ & & 30 & 70 & 5 & 5 & & & & 1 & & & & 1 & & 5 & 20 & 55 & 10 & 15 & & 5 & & \\
\hline $28-4,58$ & 10 & 30 & 60 & 5 & & & & 5 & 1 & & & & & • & & 30 & 35 & 5 & 20 & & & & \\
\hline $29-1,80$ & & 20 & 80 & & & & & 5 & & & & & 1 & & & & 30 & & 65 & 1 & & & \\
\hline $30-2,70$ & 2 & 25 & 70 & & & & & 25 & & & & & 10 & 1 & & 15 & & 25 & 25 & & & & \\
\hline $31-2,140$ & & 10 & 90 & 3 & 2 & & & 5 & & & & & & 1 & & 20 & & 5 & 60 & & & & \\
\hline $31-3,30$ & 10 & 30 & 60 & 5 & 10 & & & & & 5 & & & 15 & & & & & 20 & 55 & & & & \\
\hline $32-5,76$ & 5 & 55 & 40 & 5 & 5 & 1 & & 5 & & & & & 10 & 5 & & 5 & & 15 & 50 & & & & \\
\hline $33-4,106$ & 5 & 25 & 70 & 5 & 10 & & & 10 & & & 1 & & 5 & 10 & & & & 10 & 50 & & & & \\
\hline $34-4,55$ & 5 & 25 & 70 & 5 & 5 & 1 & & 5 & & & & & & 5 & 10 & & & 20 & 50 & & & & \\
\hline $34-6,90$ & 5 & 25 & 70 & 5 & 5 & 5 & & 10 & 1 & & & & 10 & & & 10 & & 20 & 35 & & & & \\
\hline $35-3,75$ & 5 & 45 & 50 & 5 & 10 & 5 & & 10 & $i$ & & & & 15 & 15 & & 5 & & 10 & 30 & & & & \\
\hline $36-6,110$ & 5 & 40 & 55 & 1 & 1 & & & 5 & 5 & & & & & 5 & & 15 & & 25 & 45 & & & & \\
\hline CB between Cores $38 / 39$ & 1 & 30 & 70 & & & & & & & & & & & 1 & & 90 & & 1 & 5 & & & & \\
\hline $40-3,105$ & 5 & 35 & 60 & 5 & 10 & & 1 & 10 & 20 & 5 & & & & 1 & 1 & 10 & & 10 & 25 & & & & \\
\hline $40-4,45$ & & 10 & 90 & & & & & 55 & 30 & 5 & & & & & 10 & & & & & & & & \\
\hline $41-2,80$ & & 10 & 90 & & & & & 80 & 10 & & & 10 & & & & & & & & & & & \\
\hline $41-4,100$ & 5 & 35 & 60 & 5 & 10 & & & 5 & 20 & & & & & 1 & 5 & 10 & & 10 & 35 & & & & \\
\hline $42-4,100$ & 5 & 35 & 60 & 1 & 1 & 1 & & 20 & 15 & & & 1 & & 1 & 10 & 30 & & 5 & 20 & & & & \\
\hline $43-3,150$ & 5 & 35 & 60 & 5 & 5 & & & 15 & 5 & & & & & 5 & 5 & 10 & & 20 & 30 & & & & \\
\hline $44-6,90$ & & 45 & 55 & 5 & 5 & & & 10 & 15 & & & & & 5 & 5 & 20 & & 15 & 25 & & & & \\
\hline $46-3,100$ & & 50 & 50 & 5 & 5 & & & 10 & 15 & & & & & 5 & 5 & 15 & & 10 & 30 & & & & \\
\hline $47-3,2$ & & 50 & 50 & 5 & 5 & 1 & & 10 & 5 & 5 & & & & 15 & 1 & 25 & 15 & & 15 & & & & burrow fill \\
\hline $48-6,70$ & & 30 & 70 & 1 & 1 & & & 5 & 1 & & & & & 10 & & 35 & 25 & 10 & 15 & & & & \\
\hline $49-6,60$ & & 15 & 85 & & 1 & & & 5 & 5 & & & & & & 10 & 30 & 40 & & 10 & & & & \\
\hline $50-6,100$ & 5 & 35 & 60 & 1 & & & & 5 & & & & 1 & & 1 & 1 & 60 & 30 & 2 & 2 & & 1 & & \\
\hline $50-6,130$ & 1 & 10 & 90 & 1 & & & & 90 & & & & 2 & & & 1 & 5 & & & 2 & & & & \\
\hline $51-6,125$ & & 60 & 40 & 10 & 10 & & 1 & 10 & 20 & 5 & & & & 1 & 5 & 5 & 20 & 5 & 10 & & & & \\
\hline
\end{tabular}


APPENDIX B

Carbonate and Quartz Determinations

\begin{tabular}{|c|c|c|c|c|c|}
\hline Section & $\begin{array}{l}\text { Sediment } \\
\text { Depth } \\
\text { (cm) }\end{array}$ & $\mathrm{CaCO}_{3}(\%)$ & Org (\%) & $\begin{array}{c}\text { Total } \\
\text { Carb (\%) }\end{array}$ & Qtz (\%) \\
\hline \multicolumn{6}{|c|}{ Hole 357} \\
\hline $1-2$ & 250 & 88.85 & 0.05 & 10.72 & \\
\hline $1-2$ & 353 & 85.71 & 0.44 & 10.72 & \\
\hline $2-3$ & 1230 & 85.58 & 0.89 & 11.16 & \\
\hline $3-1$ & 1945 & 87.53 & 0.22 & 10.72 & \\
\hline $3-2$ & 2095 & 88.35 & 0 & 10.60 & \\
\hline $3-3$ & 2106 & 86.17 & 0.53 & 10.87 & \\
\hline $3-3$ & 2200 & 89.65 & 0.03 & 10.79 & \\
\hline $3-3$ & 2245 & 86.88 & 0 & 10.42 & \\
\hline $3-4$ & 2395 & 86.56 & 0.18 & 10.57 & \\
\hline $3-5$ & 2545 & 88.20 & 0.80 & 10.67 & \\
\hline $3-6$ & 2600 & 69.19 & 0.67 & 8.98 & 14.17 \\
\hline $3-6$ & 2655 & 82.63 & 0.68 & 10.60 & \\
\hline $4-6$ & 3590 & 79.43 & 0.04 & 9.58 & \\
\hline $5-3$ & 4070 & 77.66 & 0.53 & 9.85 & 11.90 \\
\hline $5-5$ & 4370 & 82.11 & 0.05 & 9.91 & \\
\hline $6-5$ & 5350 & 76.82 & 0.46 & 9.68 & 13.54 \\
\hline $6-6$ & 5441 & 78.15 & 0.03 & 9.41 & \\
\hline $7-5$ & 7050 & 85.00 & 0.55 & 10.75 & 11.86 \\
\hline $8-4$ & 7082 & 86.57 & 0.02 & 10.42 & \\
\hline $8-4$ & 7270 & 90.53 & 0.57 & 10.72 & 11.70 \\
\hline $9-4$ & 8010 & 88.05 & 0,05 & 10.62 & \\
\hline $9-4$ & 8014 & 84.40 & 0.95 & 11.08 & 11.09 \\
\hline $10-4$ & 8970 & 83.54 & 0.51 & 10.54 & 11.83 \\
\hline $10-1$ & 9510 & 86.03 & 0.04 & 10.36 & \\
\hline $11-2$ & 10575 & 78.24 & 0.71 & 10.10 & 12.01 \\
\hline $11-2$ & 10594 & 83.86 & 0.04 & 10.11 & \\
\hline $12-3$ & 11670 & 85.02 & 0.69 & 10.89 & 10.46 \\
\hline $13-4$ & 13740 & 71.34 & 0.63 & 9.19 & 12.78 \\
\hline $14-1$ & 15200 & 75.00 & 0.07 & 9.07 & \\
\hline $14-2$ & 15367 & 75.43 & 0.52 & 9.57 & 13.49 \\
\hline $15-2$ & 17260 & 71.62 & 0.52 & 9.11 & 12.03 \\
\hline $16-2$ & 18200 & 76.06 & 0.41 & 9.54 & 12.15 \\
\hline $17-2$ & 19150 & 74.53 & 0.16 & 9.11 & 11.85 \\
\hline $17-3$ & 19280 & 77.25 & 0.05 & 9.32 & \\
\hline $18-2$ & 21022 & 75.95 & 0.25 & 9.37 & 10.94 \\
\hline $18-2$ & 22036 & 83.00 & 0.05 & 10.02 & \\
\hline $19-2$ & 23854 & 76.71 & 0.34 & 9.55 & \\
\hline $19-2$ & 23919 & 77.97 & 0.06 & 9.42 & \\
\hline $20-2$ & 25780 & 81.42 & 0.14 & 9.91 & 9.46 \\
\hline $20-3$ & 25981 & 81.76 & 0.04 & 9.86 & \\
\hline $21-1$ & 28467 & 69.16 & 0.10 & 8.40 & 1.67 \\
\hline $21-2$ & 28675 & 80.64 & 0.19 & 9.87 & \\
\hline $21 \mathrm{CC}$ & 28875 & 78.94 & 0.29 & 9.76 & 2.48 \\
\hline $22-2$ & 30533 & 78.01 & 0.38 & 9.75 & \\
\hline $22-4$ & 30840 & 77.27 & 0.07 & 9.34 & \\
\hline
\end{tabular}

APPENDIX B - Continued

\begin{tabular}{|c|c|c|c|c|c|}
\hline Section & $\begin{array}{l}\text { Sediment } \\
\text { Depth } \\
\text { (cm) }\end{array}$ & $\mathrm{CaCO}_{3}(\%)$ & Org (\%) & $\begin{array}{c}\text { Total } \\
\text { Carb (\%) }\end{array}$ & Qtz (\%) \\
\hline $22-4$ & 30890 & 78.71 & 0.45 & 9.89 & 2.59 \\
\hline $23-1$ & 33155 & 82.22 & 0.22 & 10.16 & 1.87 \\
\hline $23-3$ & 33361 & 71.55 & 0.45 & 9.03 & 0.00 \\
\hline $23 \mathrm{CC}$ & 34075 & 75.98 & 0.42 & 9.54 & 1.49 \\
\hline $24-1$ & 35097 & 67.90 & 0.22 & 8.37 & 1.06 \\
\hline $24-1$ & 35198 & 86.00 & 0.05 & 10.38 & \\
\hline $24-5$ & 35734 & 26.05 & 0.61 & 3.74 & .33 \\
\hline $26-3$ & 38347 & 66.44 & 0.36 & 8.33 & 1.26 \\
\hline $26-6$ & 38684 & 63.90 & 0.07 & 7.74 & \\
\hline $27-3$ & 41161 & 48.96 & 0.26 & 6.13 & .79 \\
\hline $27-4$ & 41296 & 33.03 & 0.06 & 4.03 & \\
\hline $28-3$ & 44018 & 57.86 & 0.69 & 7.64 & .78 \\
\hline $28-3$ & 44024 & 76.02 & 0.06 & 9.19 & \\
\hline $30-1$ & 47451 & 73.49 & 0.82 & 9.64 & 5.12 \\
\hline $31-2$ & 49574 & 68.33 & 0.63 & 8.83 & 8.55 \\
\hline $31-2$ & 49575 & 75.25 & 0.05 & 9.08 & \\
\hline $31-3$ & 49695 & 75.87 & 0.04 & 9.15 & \\
\hline $32-1$ & 50349 & 72.84 & 0.52 & 9.26 & 8.43 \\
\hline $33-3$ & 52596 & 58.19 & 0.37 & 7.35 & 10.62 \\
\hline $33-5$ & 52844 & 69.24 & 0.05 & 8.36 & \\
\hline $34-4$ & 55465 & 66.73 & 0.19 & 8.20 & 13.22 \\
\hline $34-4$ & 55487 & 69.81 & 0.05 & 8.43 & \\
\hline $34-6$ & 55760 & 46.57 & 0.07 & 5.66 & \\
\hline $35-2$ & 58033 & 65.94 & 0.07 & 7.99 & \\
\hline $35-3$ & 58162 & 46.61 & 0.61 & 6.20 & 11.74 \\
\hline $36-1$ & 60770 & 44.23 & 0.08 & 5.39 & \\
\hline $36-5$ & 61324 & 74.67 & 0.05 & 9.01 & \\
\hline $36-5$ & 61324 & 68.91 & 0.57 & 8.84 & 17.71 \\
\hline $37 \mathrm{CC}$ & 64675 & 65.27 & 0.70 & 8.53 & 5.73 \\
\hline $40-1$ & 69354 & 57.41 & 0.23 & 7.12 & 14.01 \\
\hline $40-3$ & 69656 & 40.56 & 0.12 & 4.99 & \\
\hline $41-2$ & 70499 & 32.03 & 0.51 & 4.35 & 12.05 \\
\hline $42-2$ & 71432 & 38.59 & 0.23 & 4.86 & \\
\hline $42-2$ & 71492 & 52.02 & 0.64 & 6.88 & 14.92 \\
\hline $43-2$ & 72346 & 55.08 & 0.40 & 7.01 & 10.85 \\
\hline $43-2$ & 72354 & 56.92 & 0.14 & 6.97 & \\
\hline $44-2$ & 73324 & 57.99 & 0.20 & 7.16 & \\
\hline $44-2$ & 73406 & 53.47 & 0.55 & 6.97 & 15.17 \\
\hline $46-3$ & 74630 & 60.21 & 0.10 & 7.33 & \\
\hline $46-3$ & 74660 & 48.45 & 0.57 & 6.39 & 12.85 \\
\hline $47-2$ & 75113 & 30.88 & 0.11 & 3.82 & \\
\hline $47-2$ & 75170 & 50.62 & 0.40 & 6.47 & 14.74 \\
\hline $48-2$ & 76068 & 68.24 & 0.14 & 8.33 & \\
\hline $48-2$ & 76068 & 57.43 & 0.60 & 7.50 & 13.31 \\
\hline $50-1$ & 76922 & 29.09 & 1.95 & 5.44 & 13.33 \\
\hline $51-1$ & 77856 & 58.35 & 0.29 & 7.30 & 14.20 \\
\hline $50-6$ & 78555 & 36.99 & 0.11 & 4.55 & \\
\hline $51-6$ & 79578 & 53.06 & 0.20 & 6.57 & \\
\hline
\end{tabular}


옴

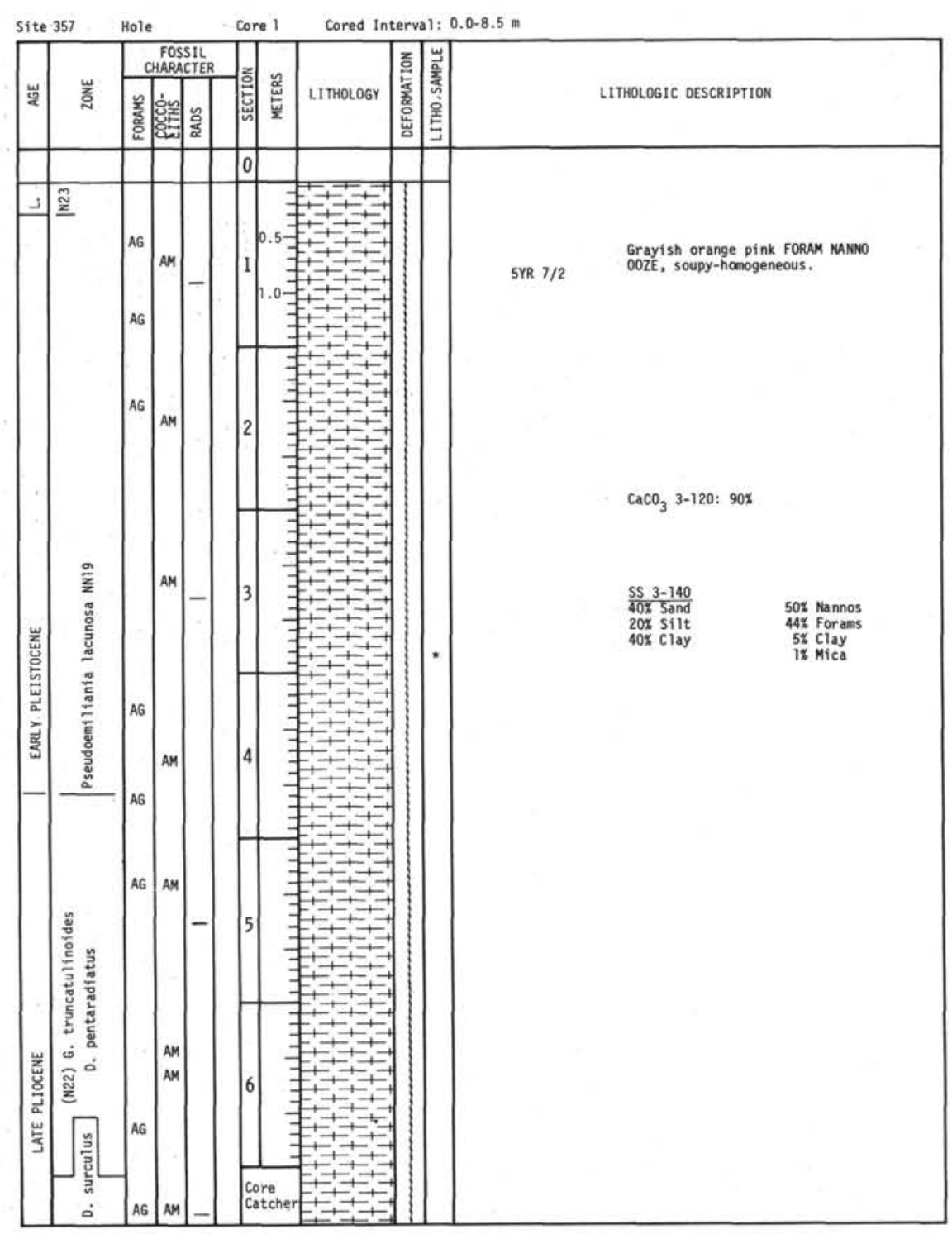

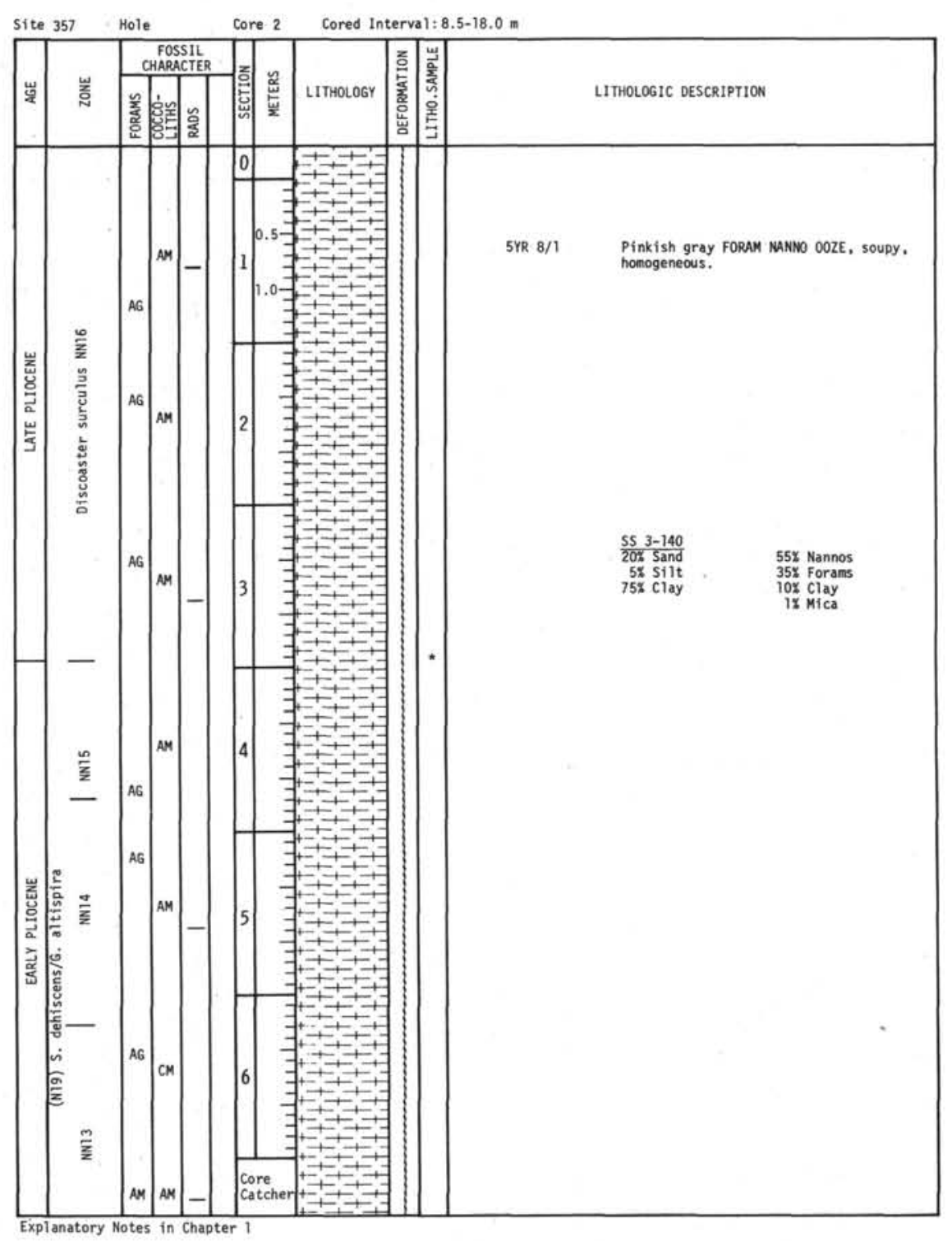



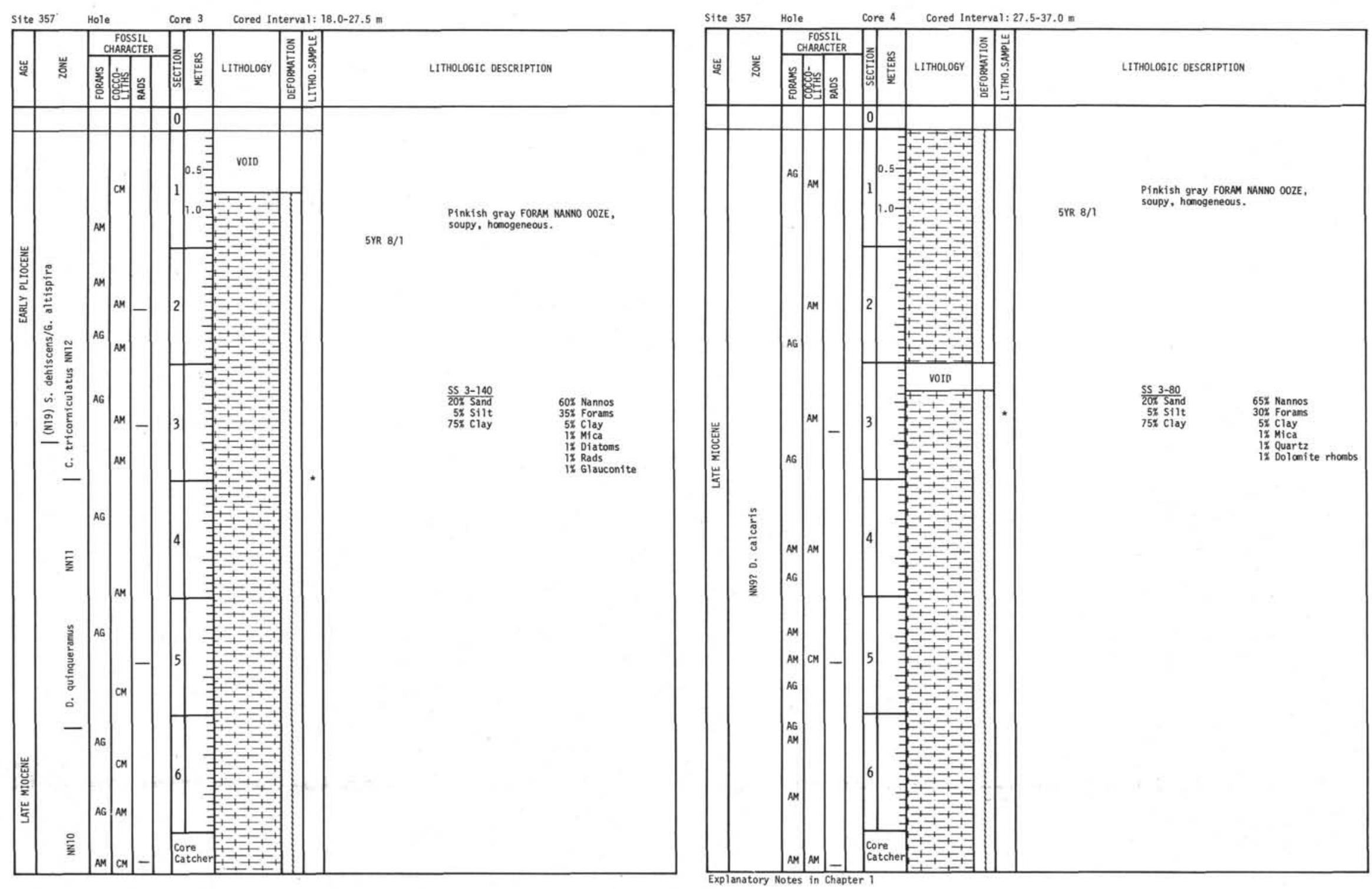

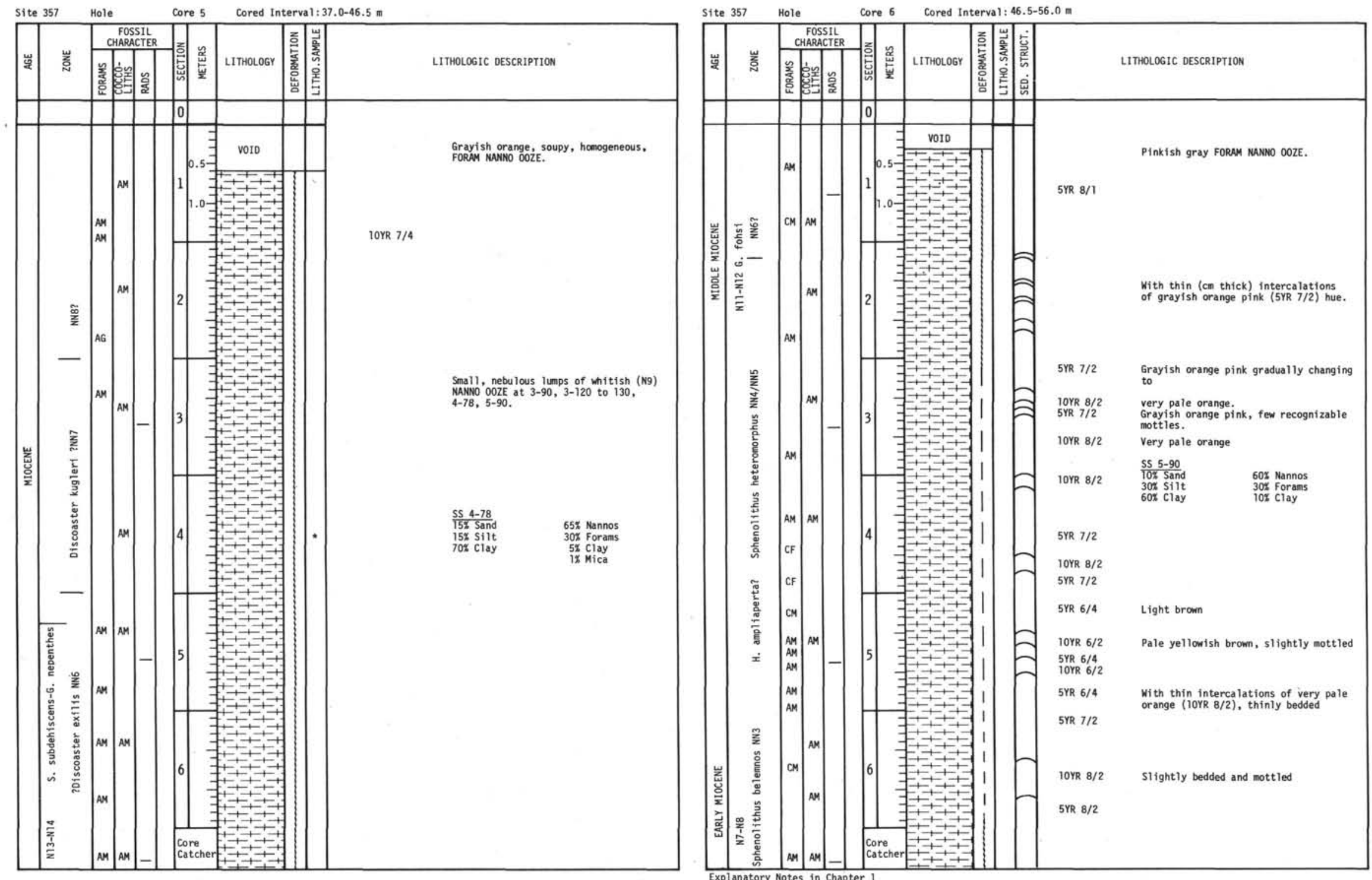

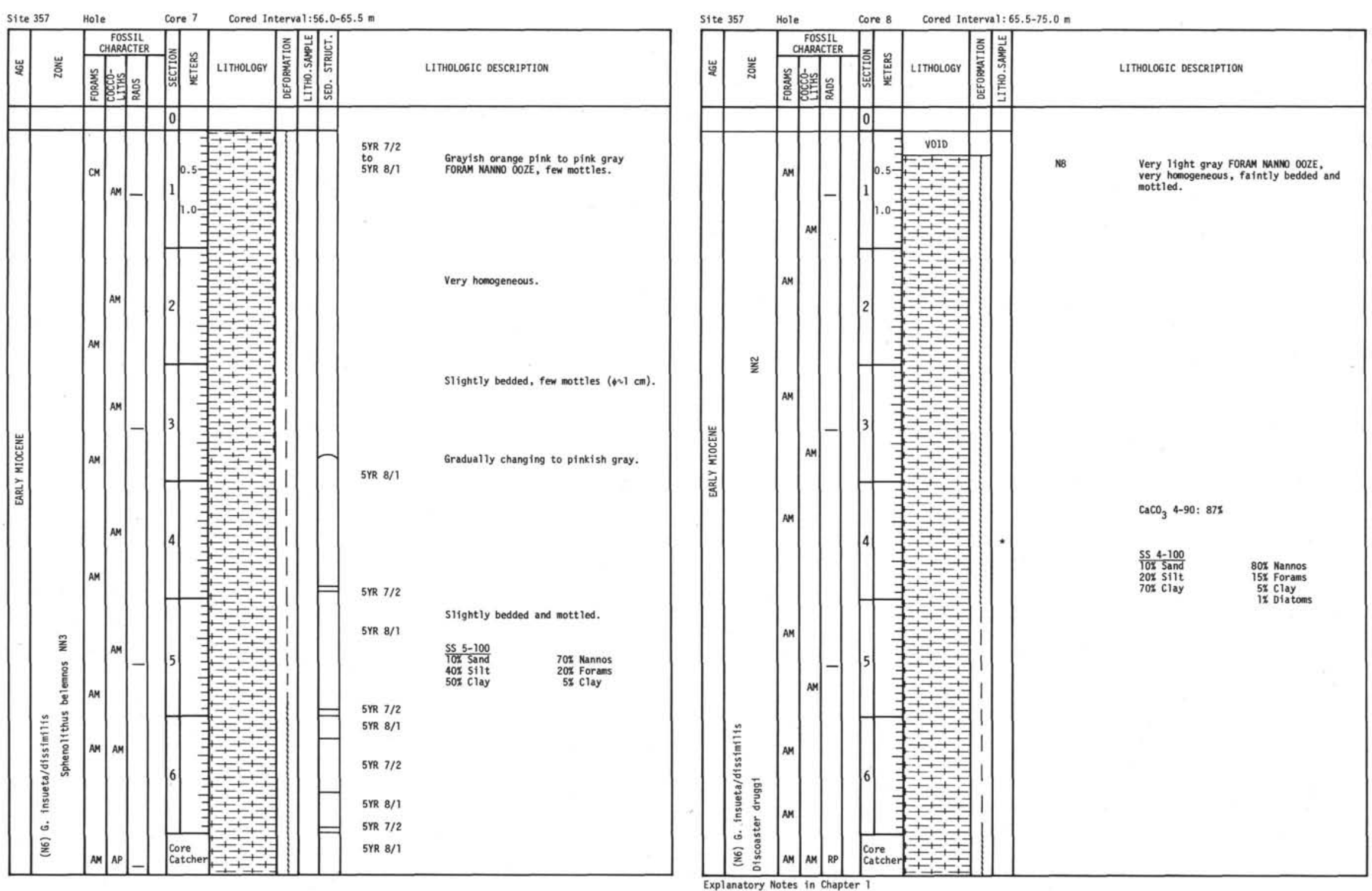


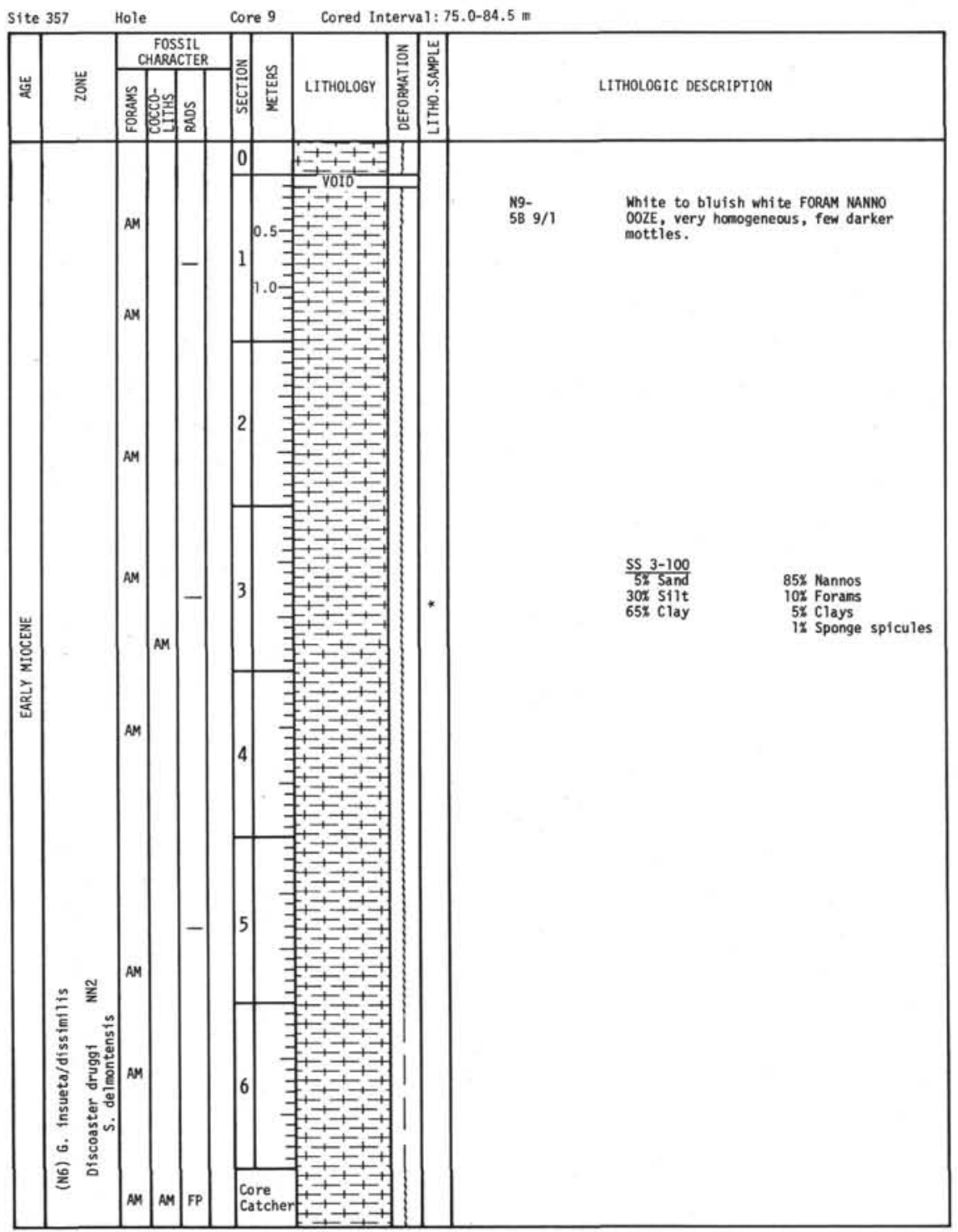

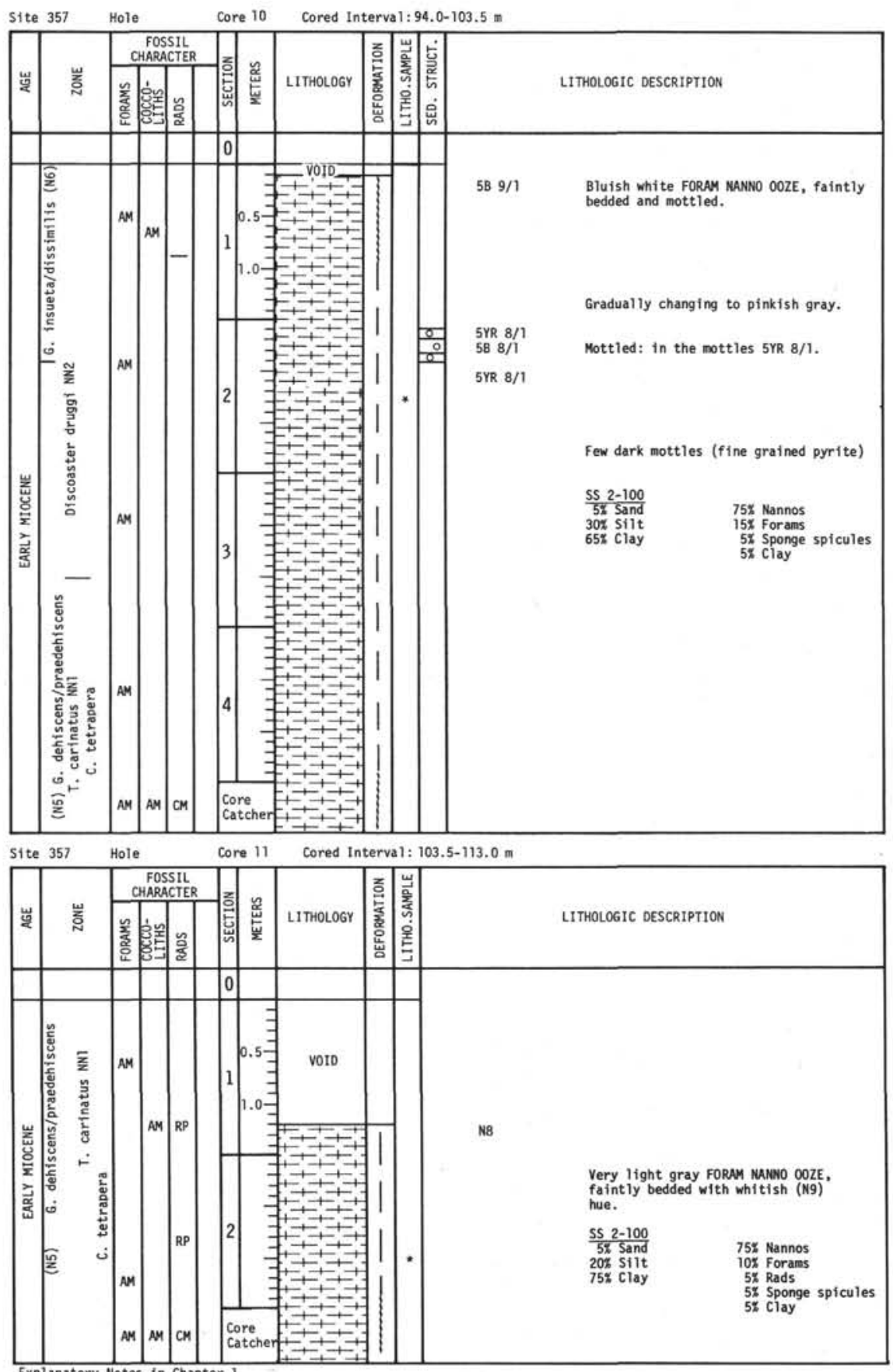



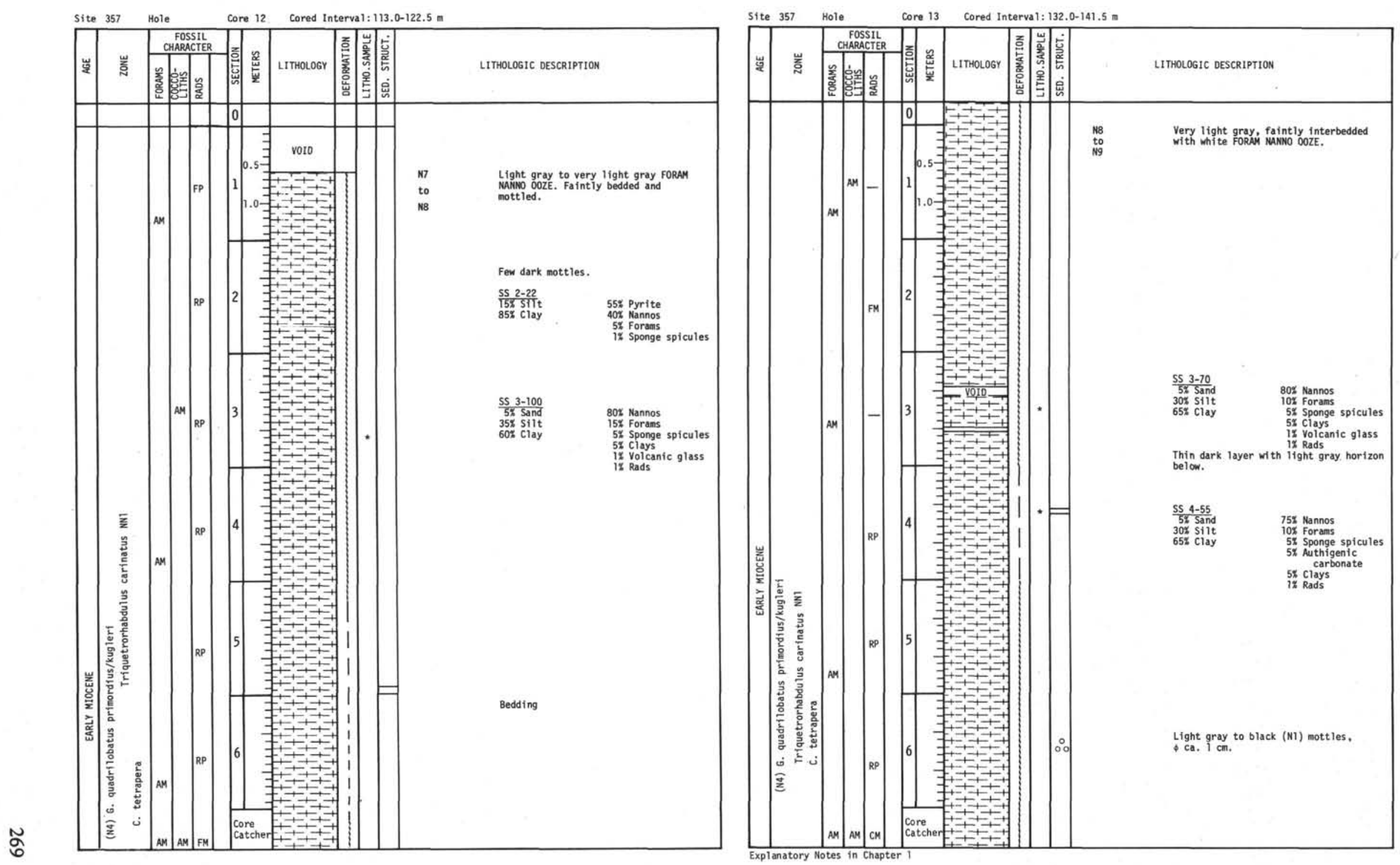

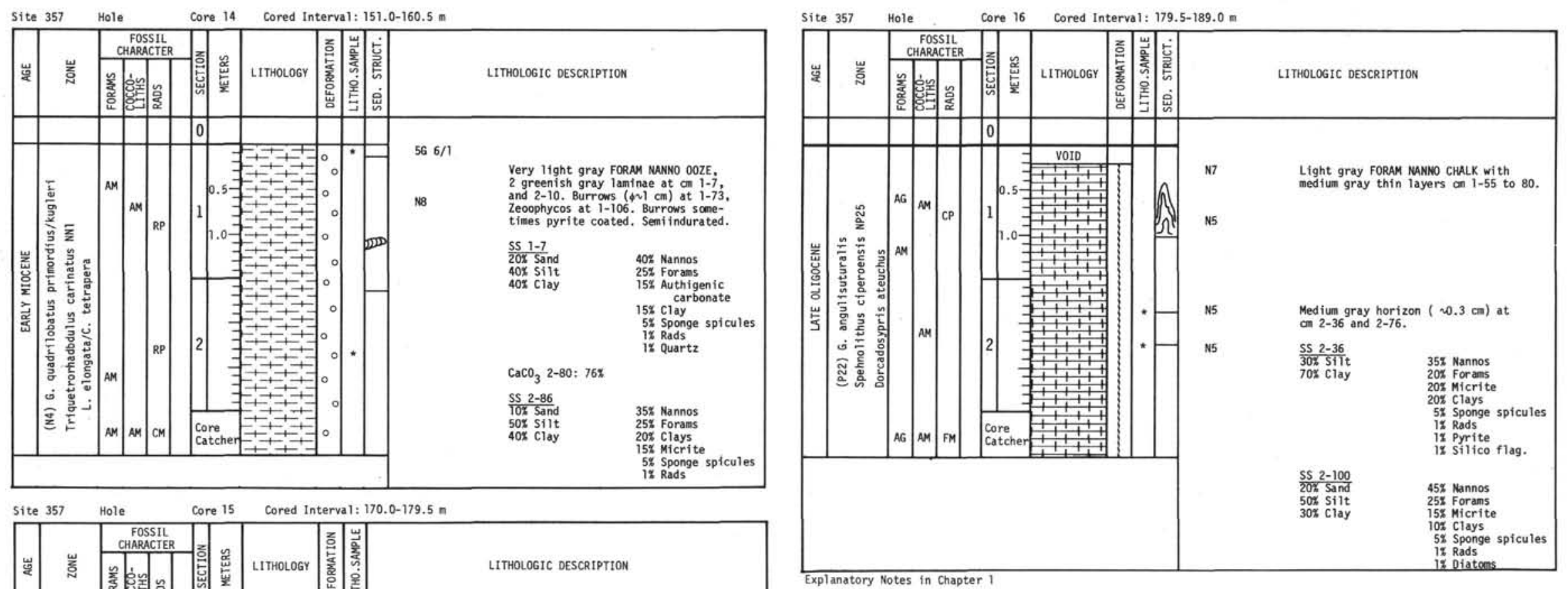

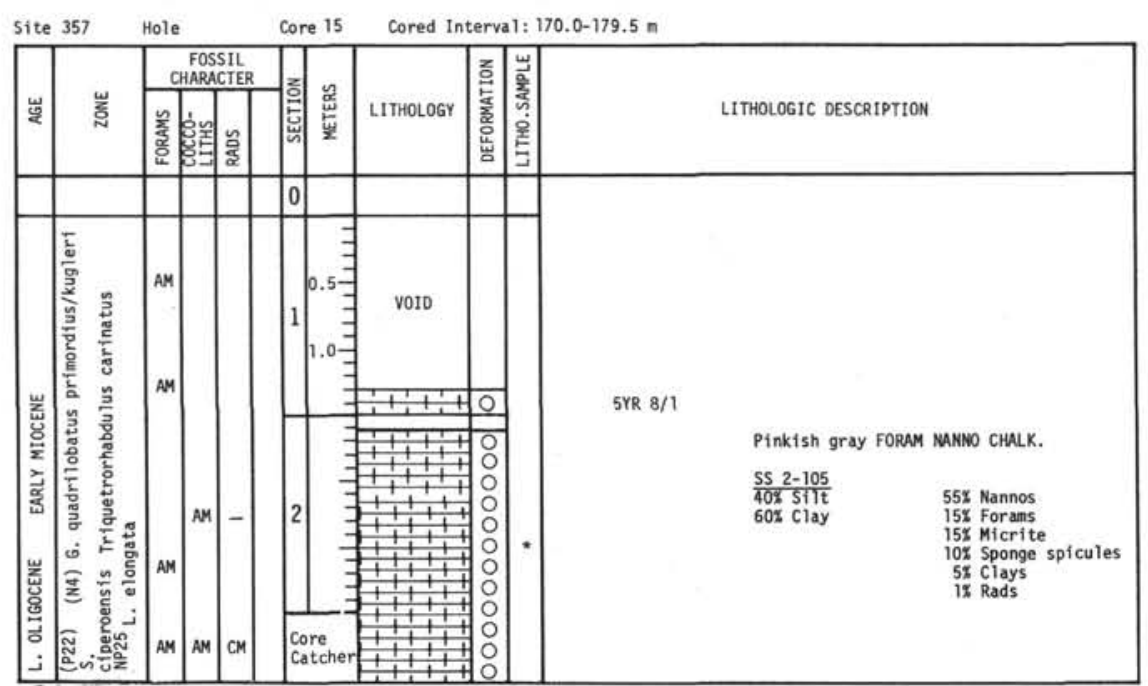




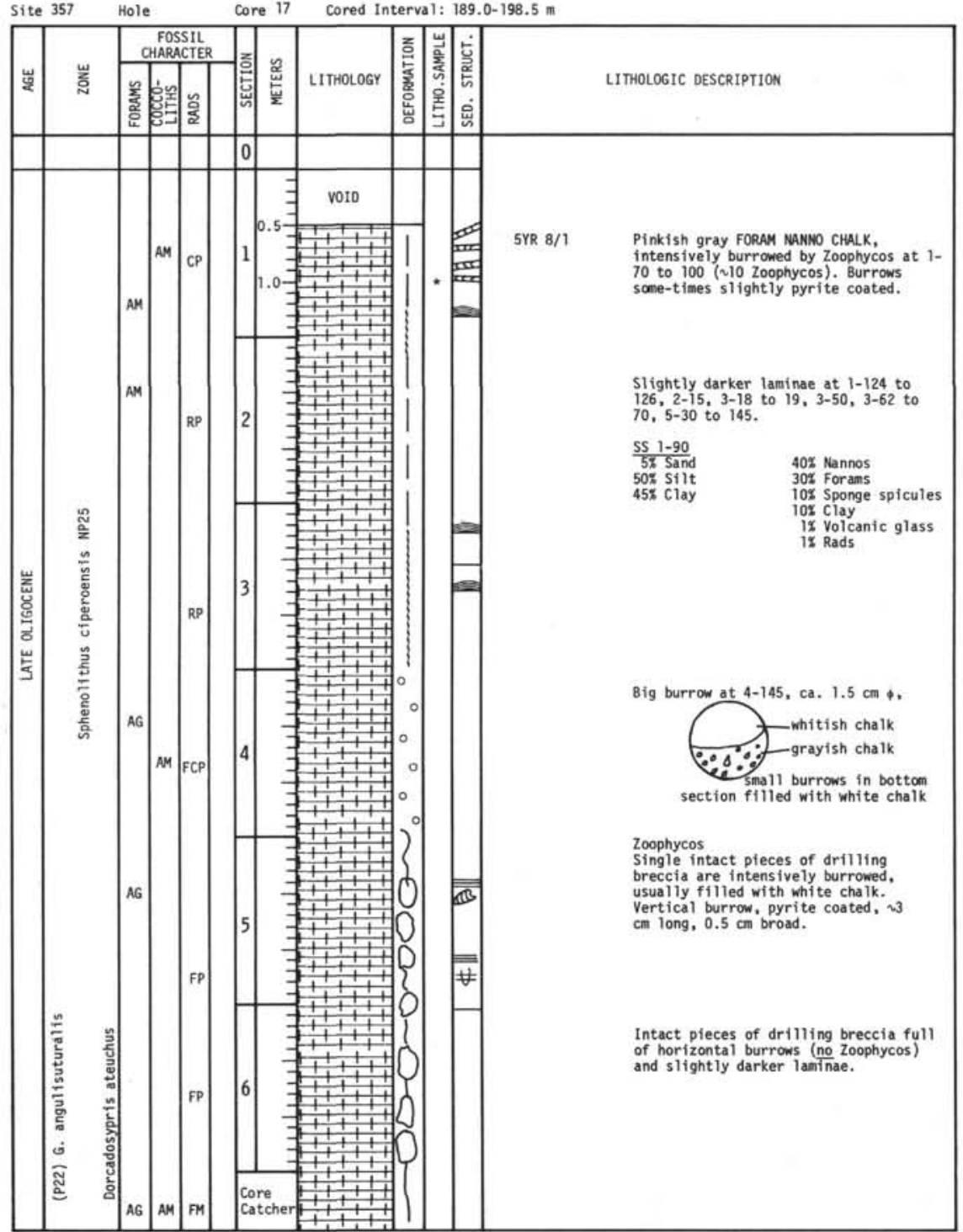

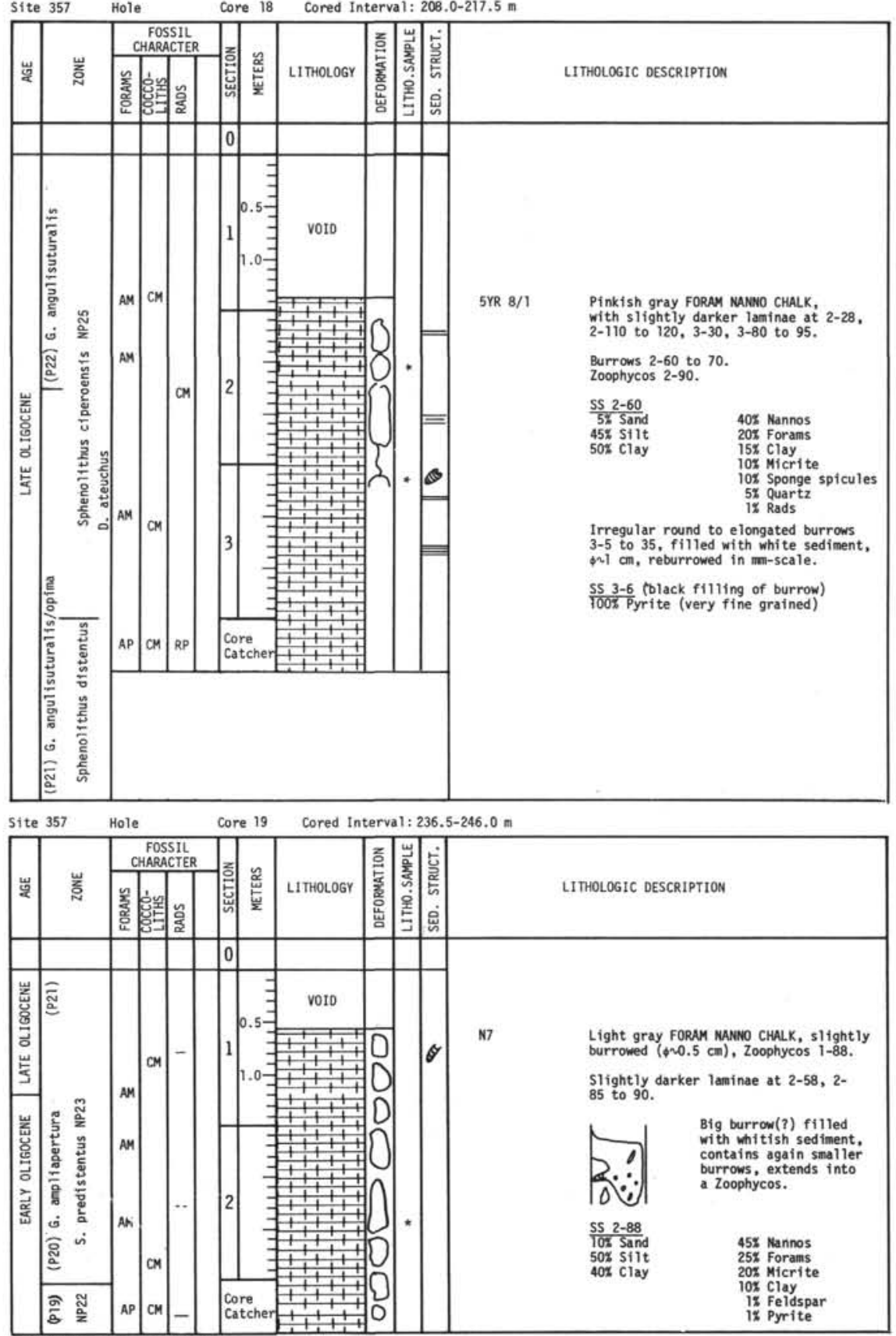




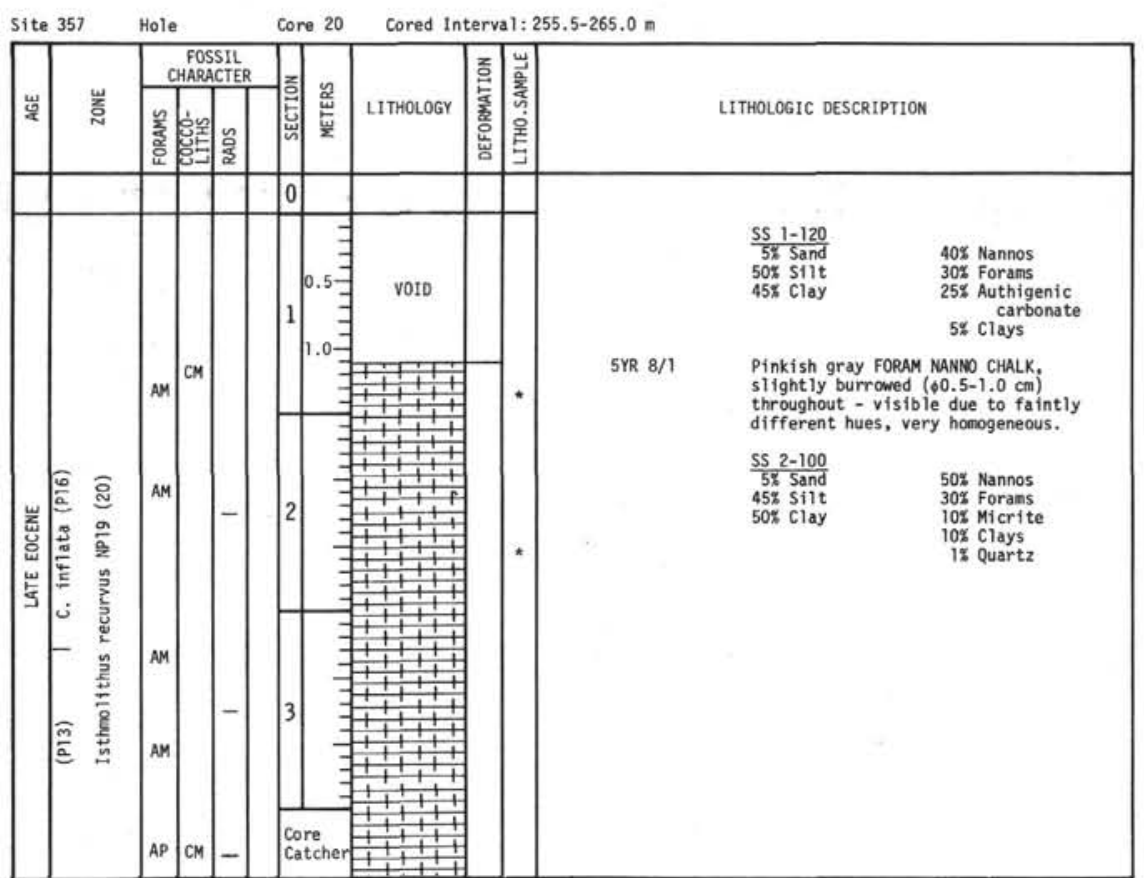

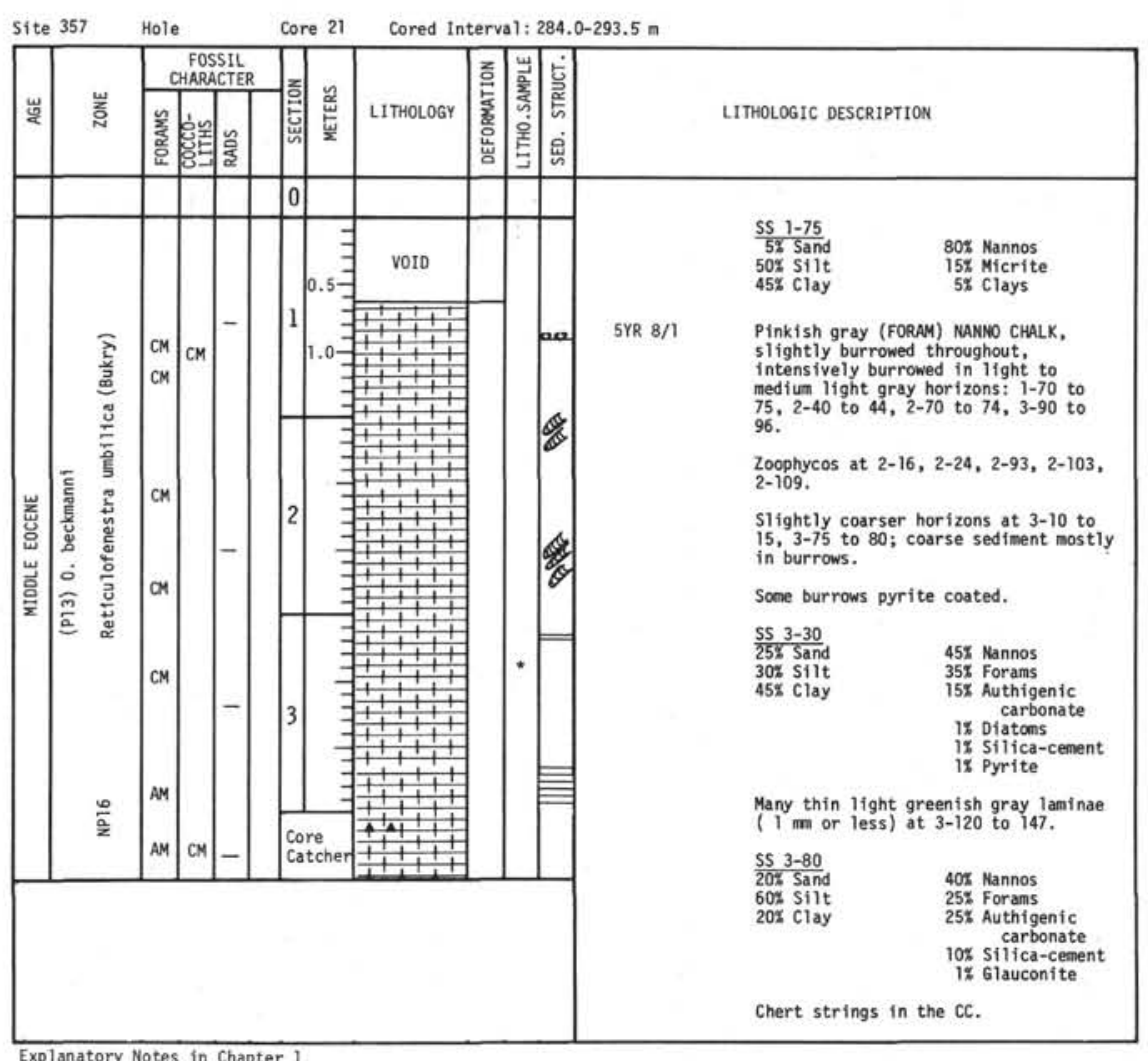



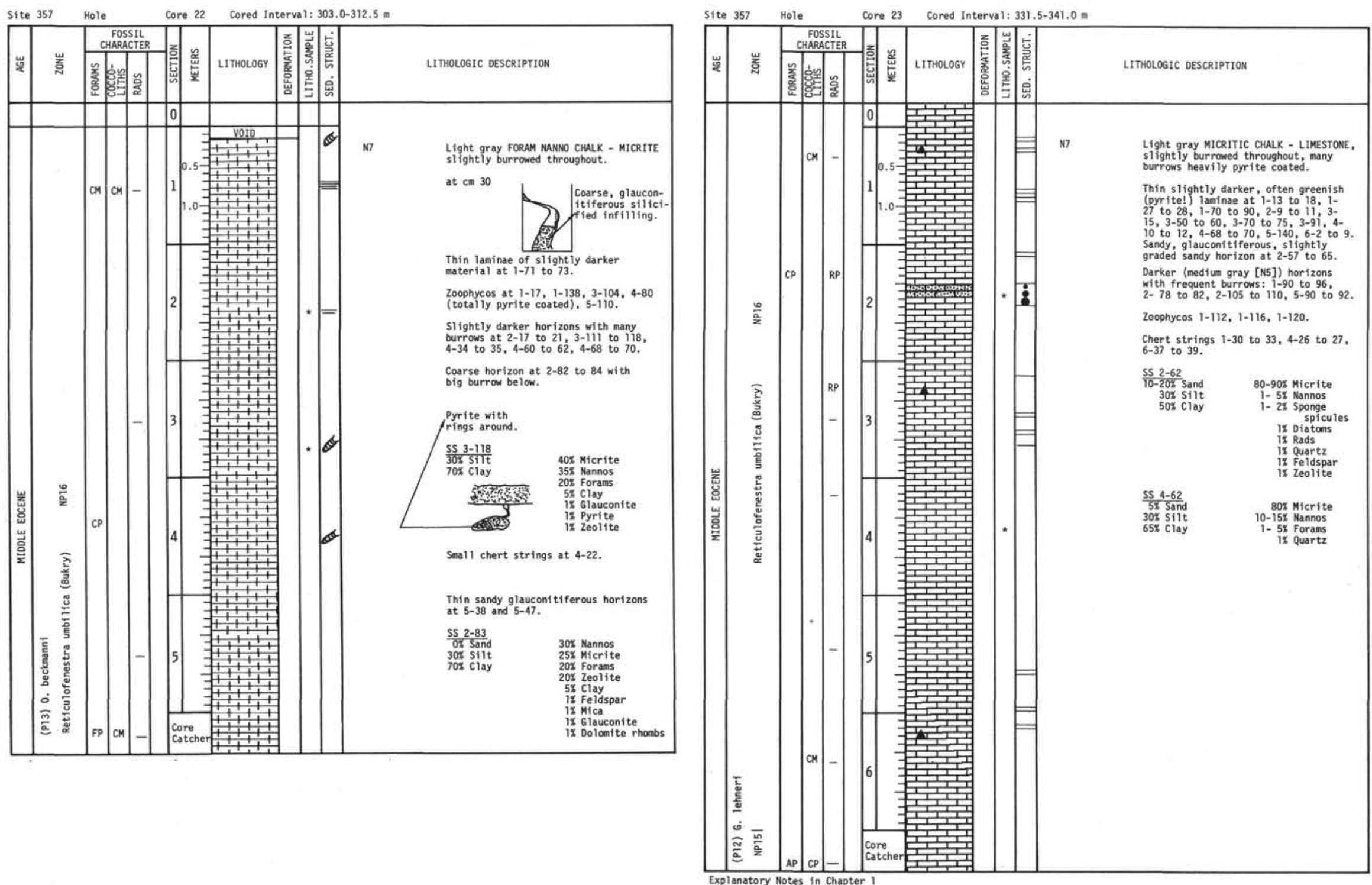


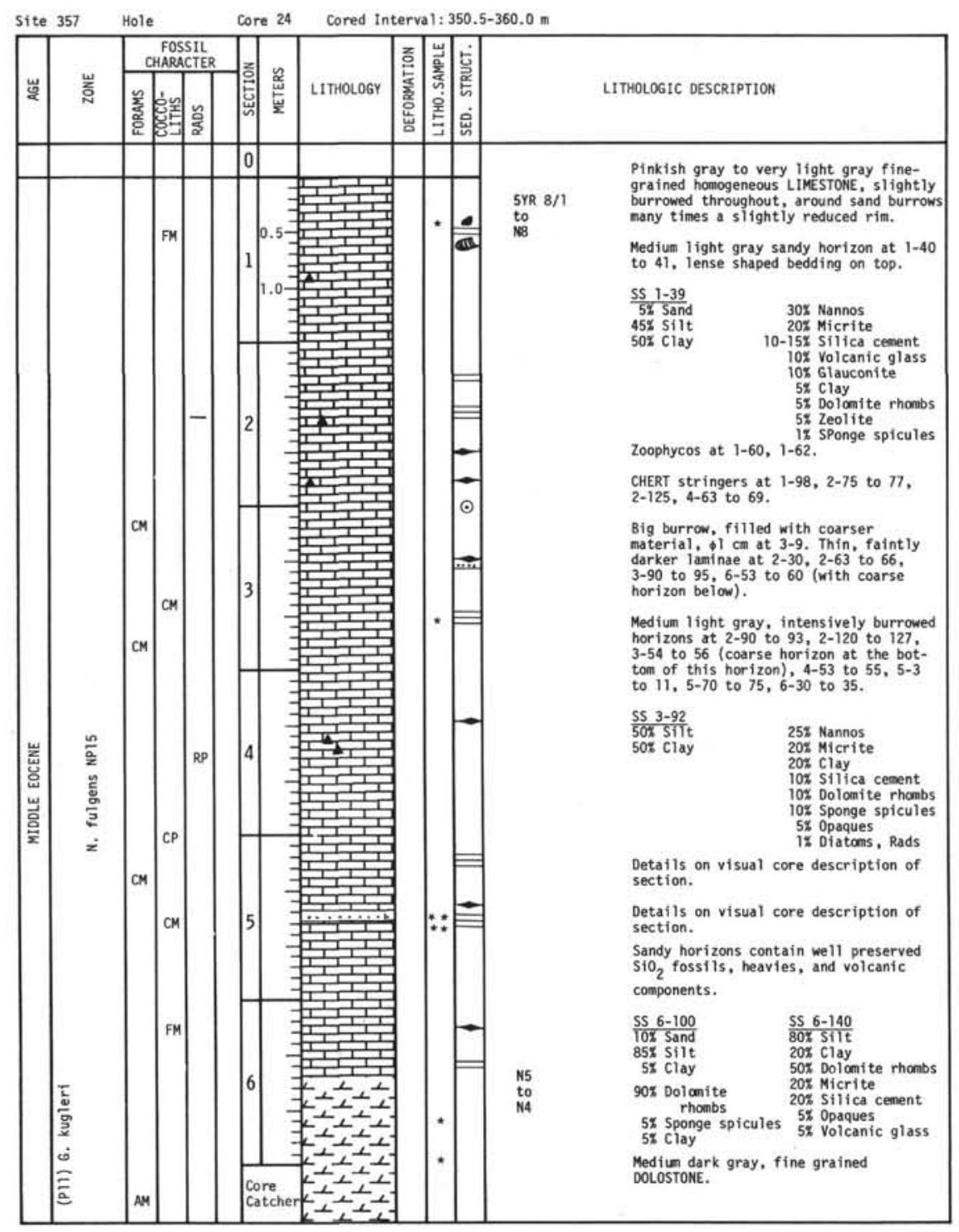

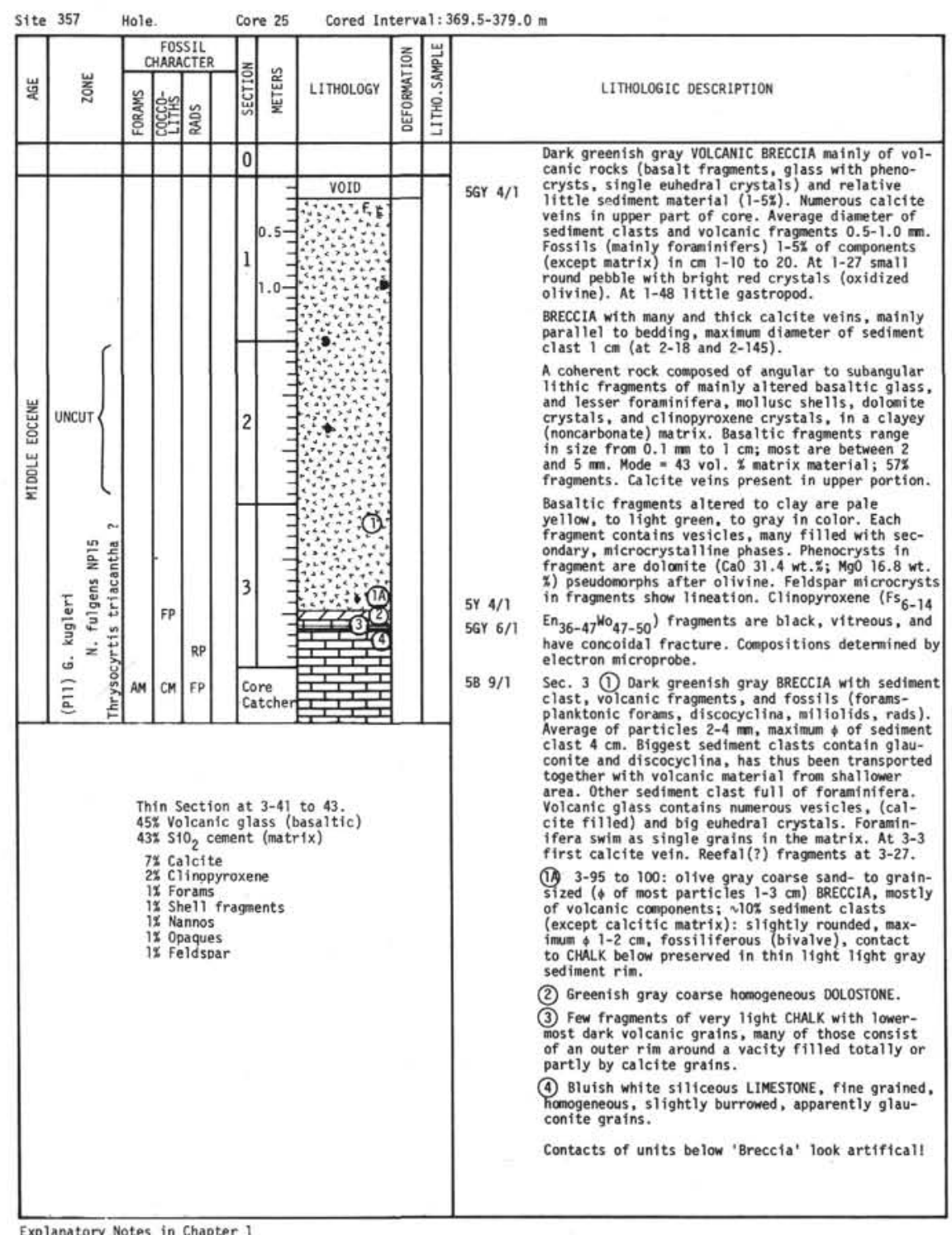



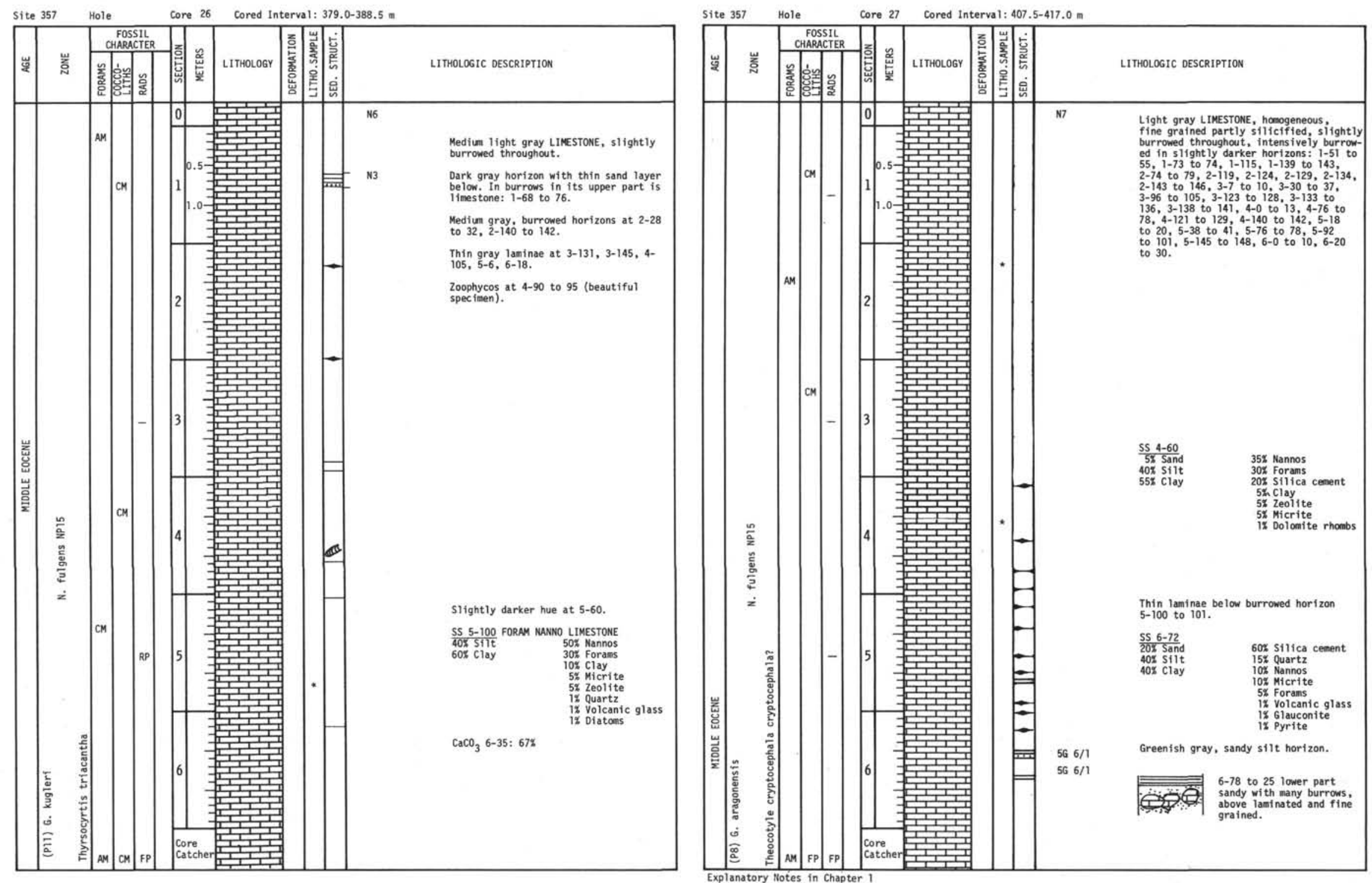

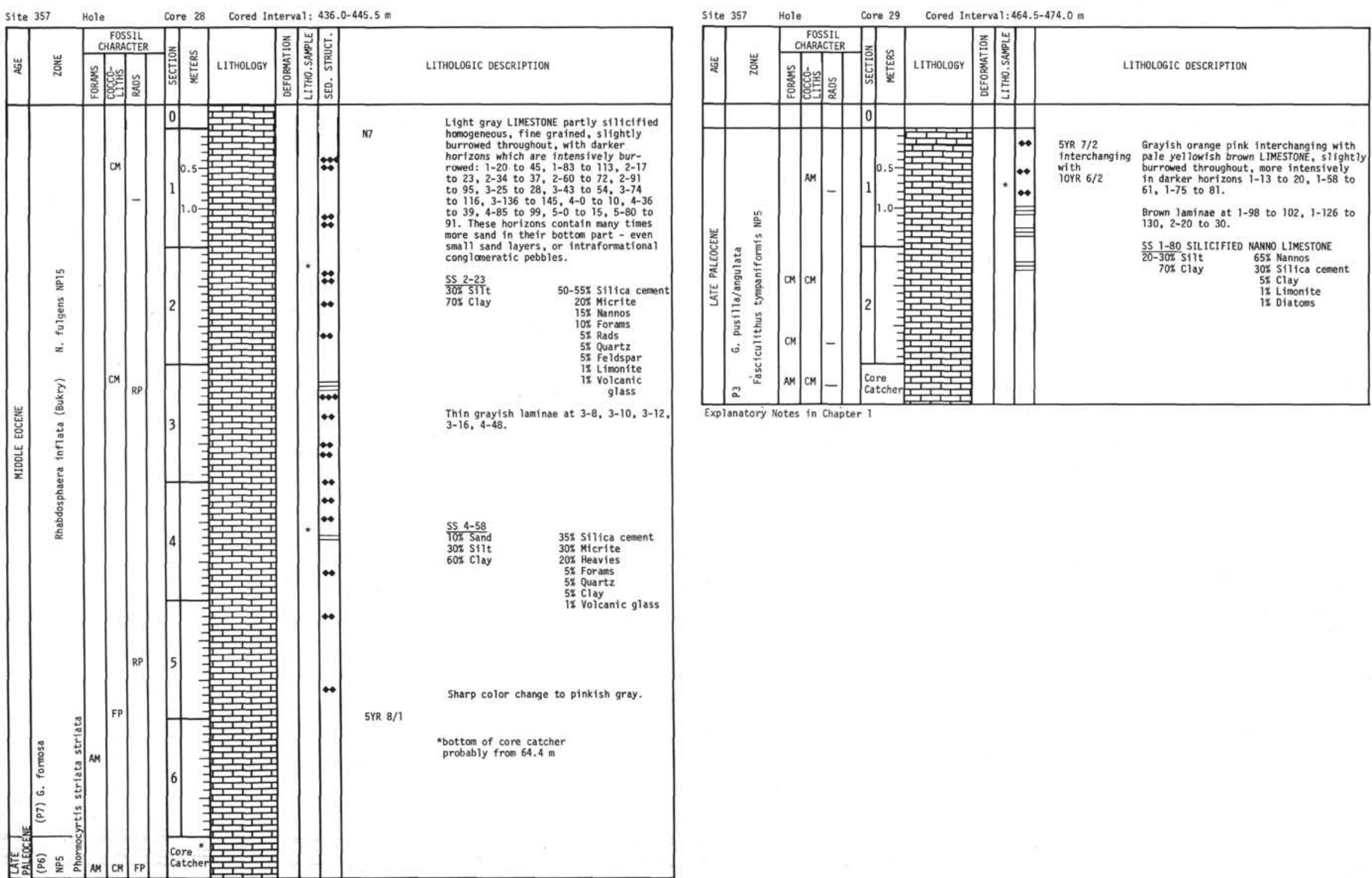

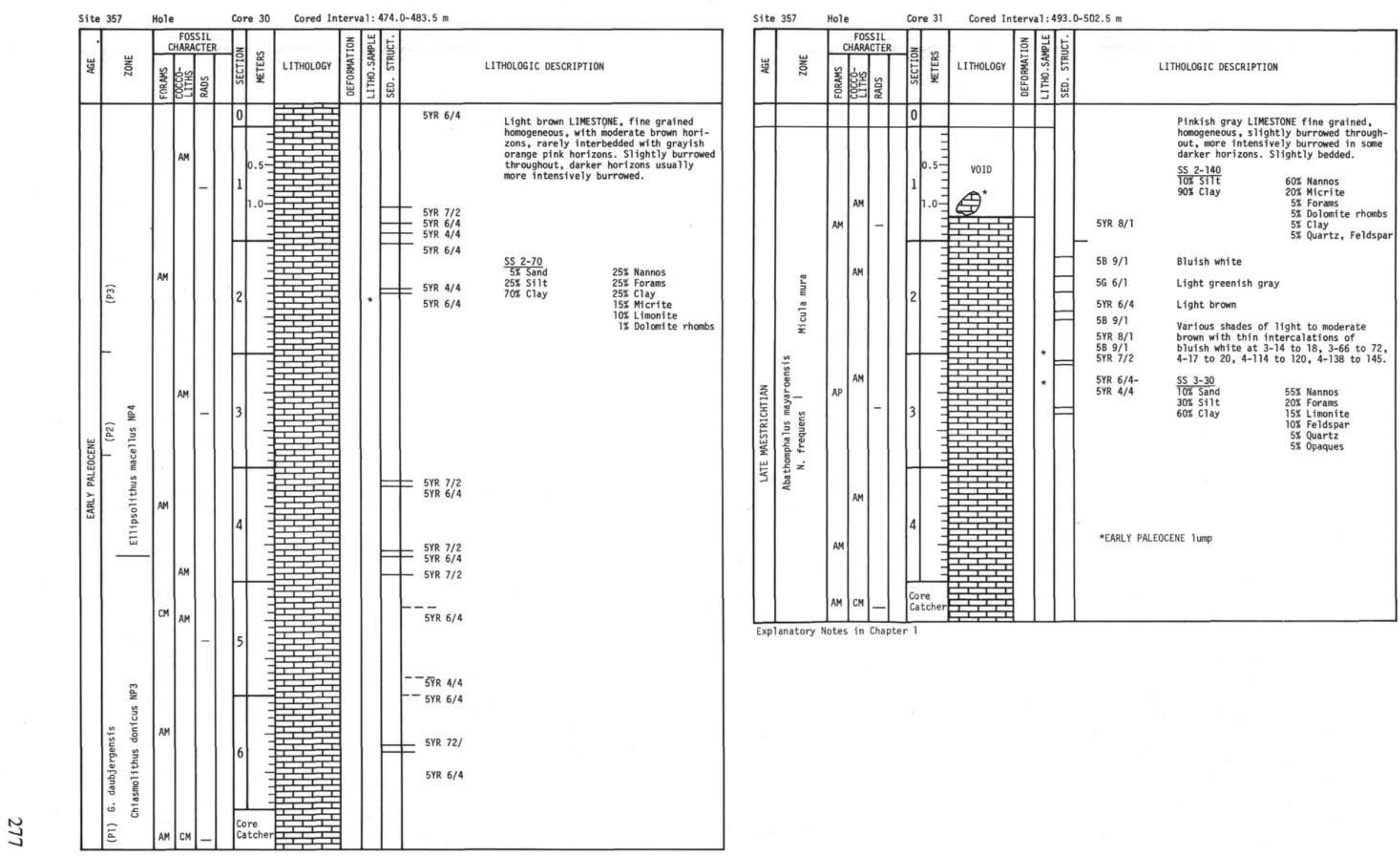


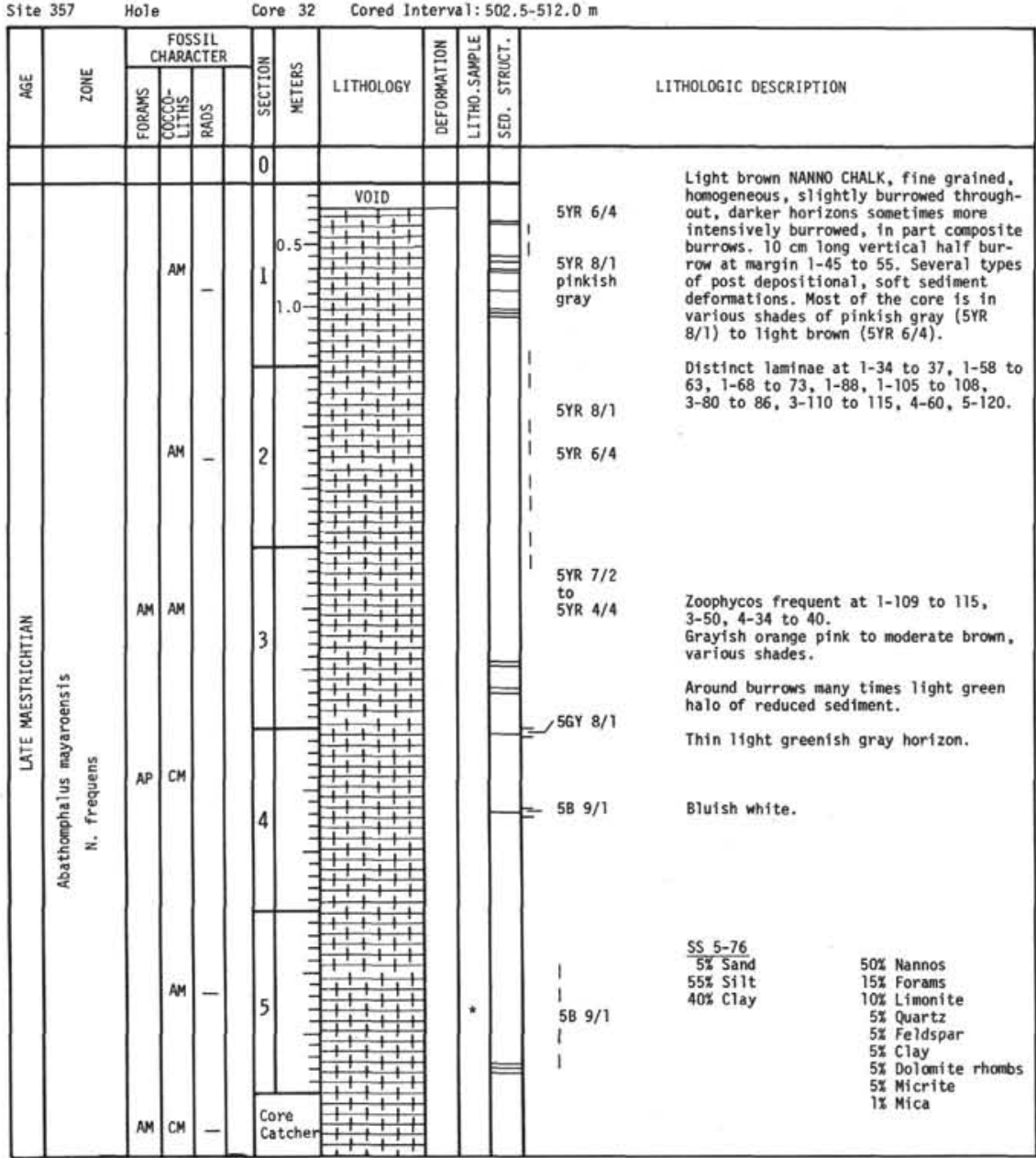

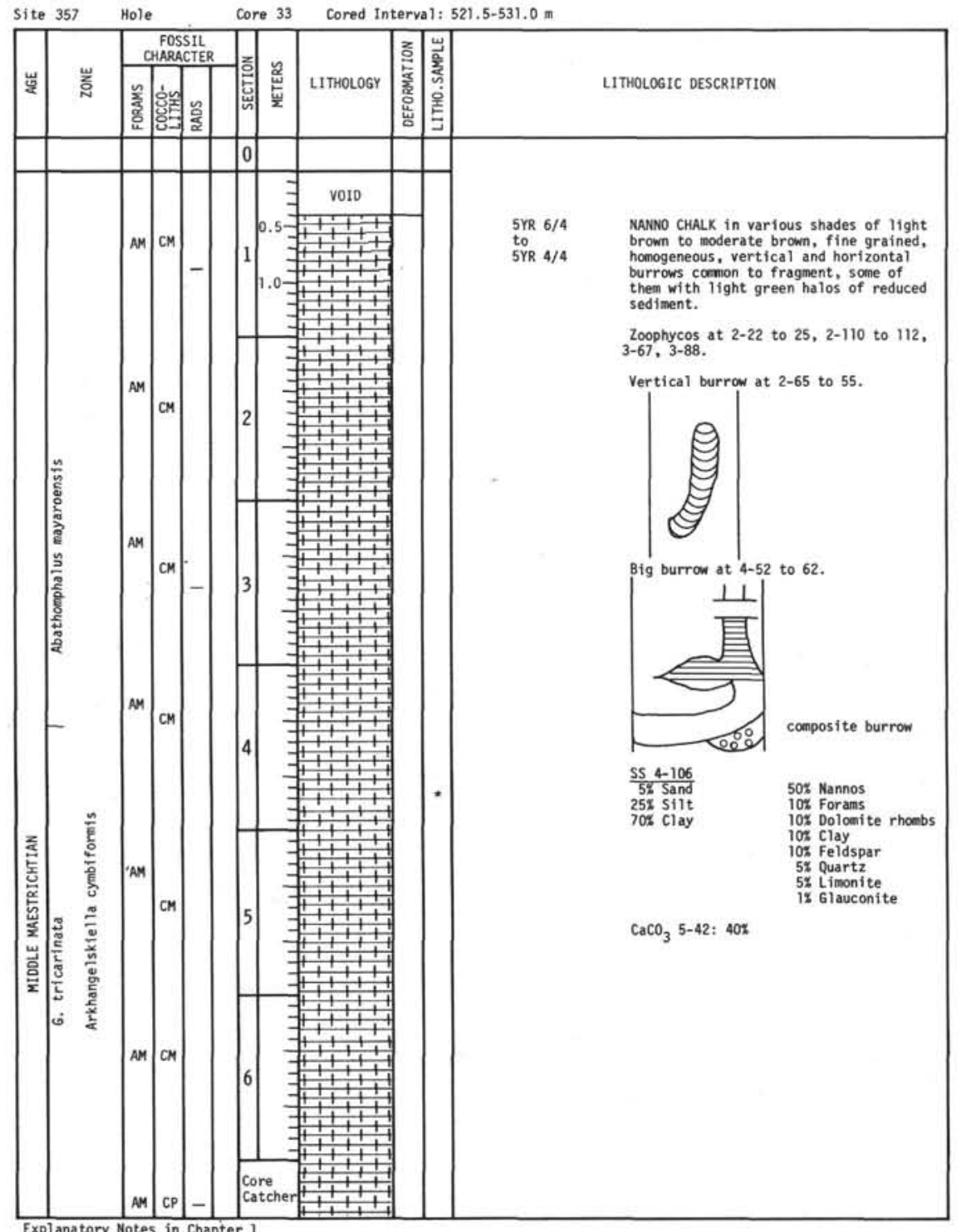



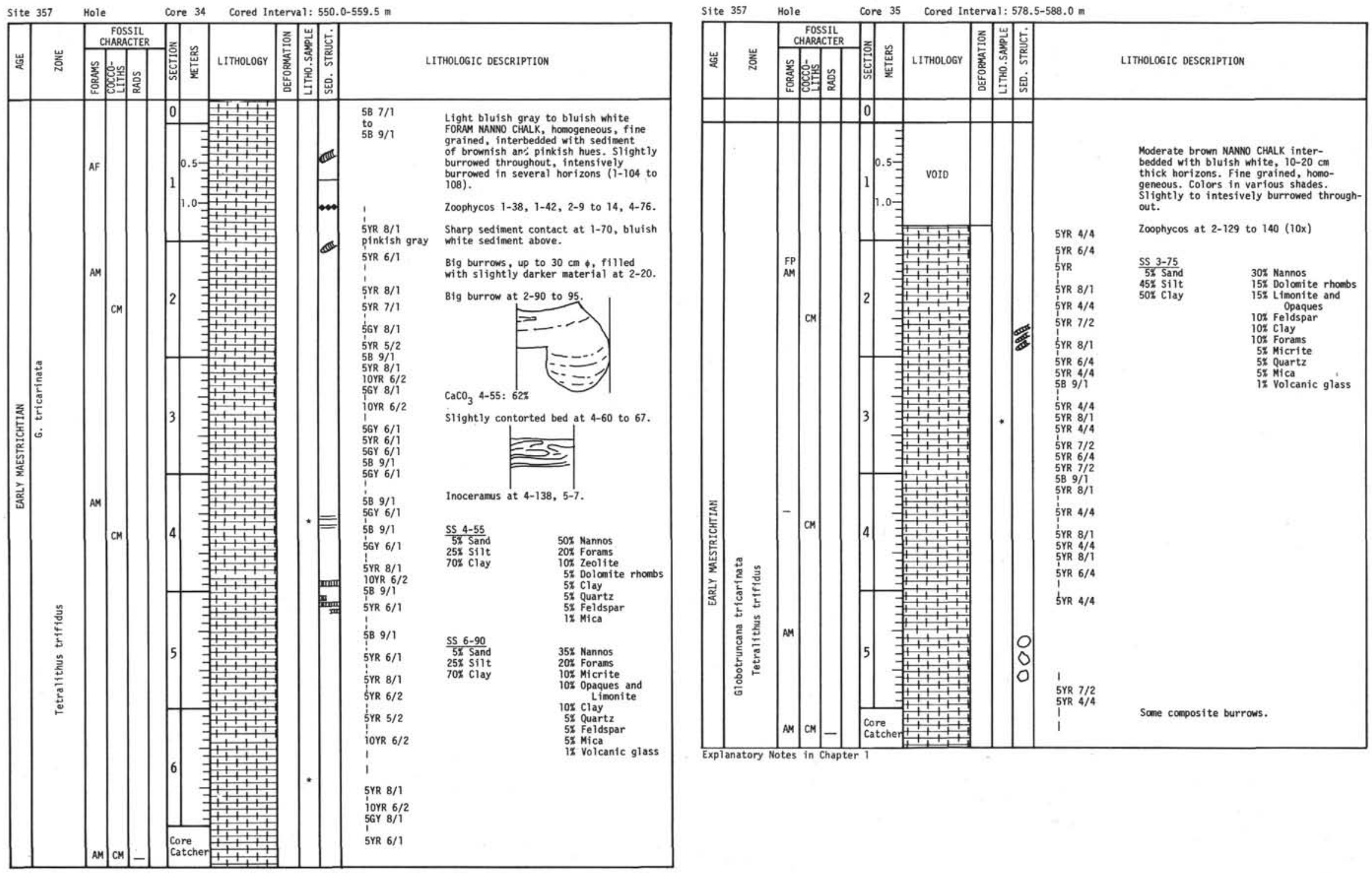


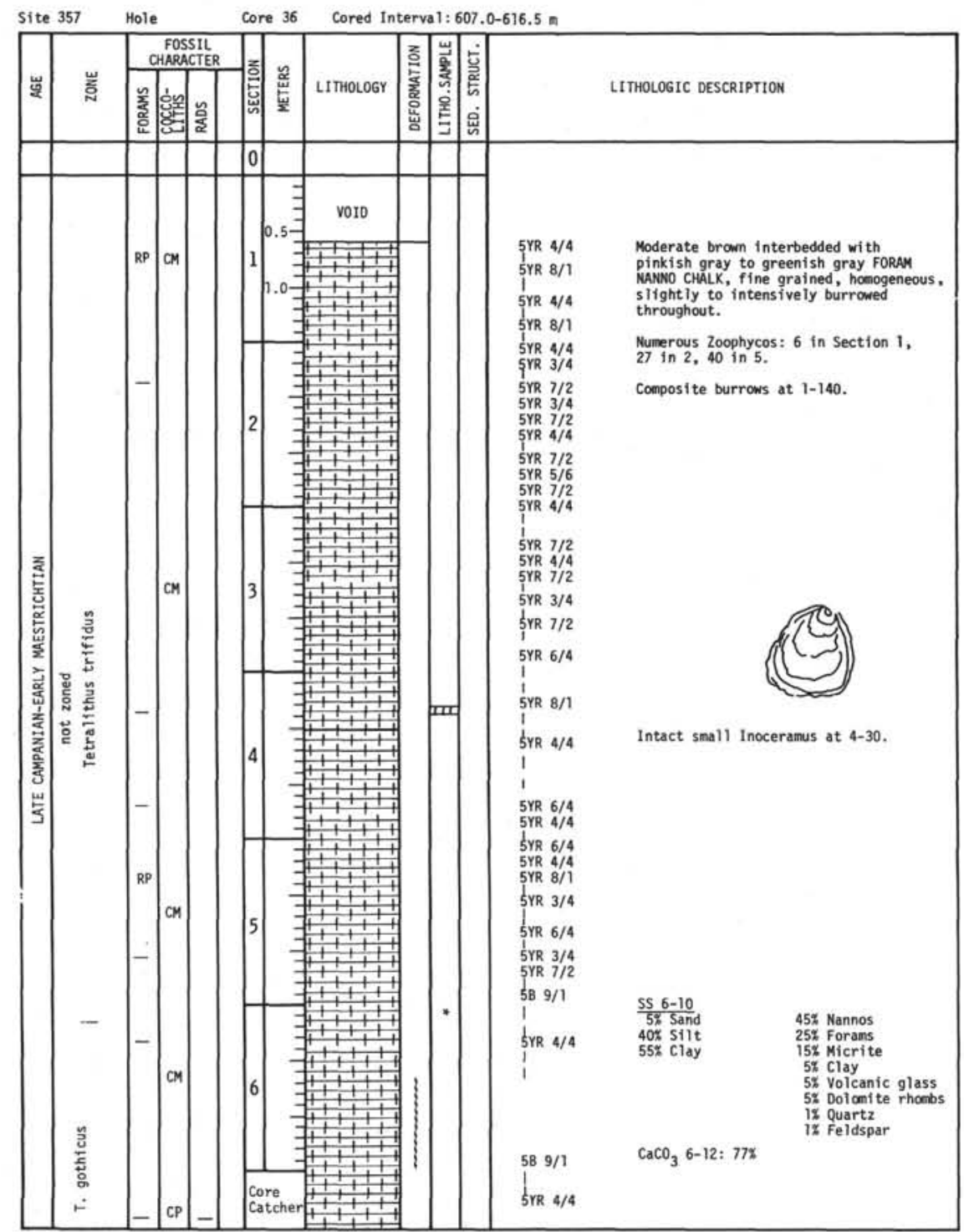
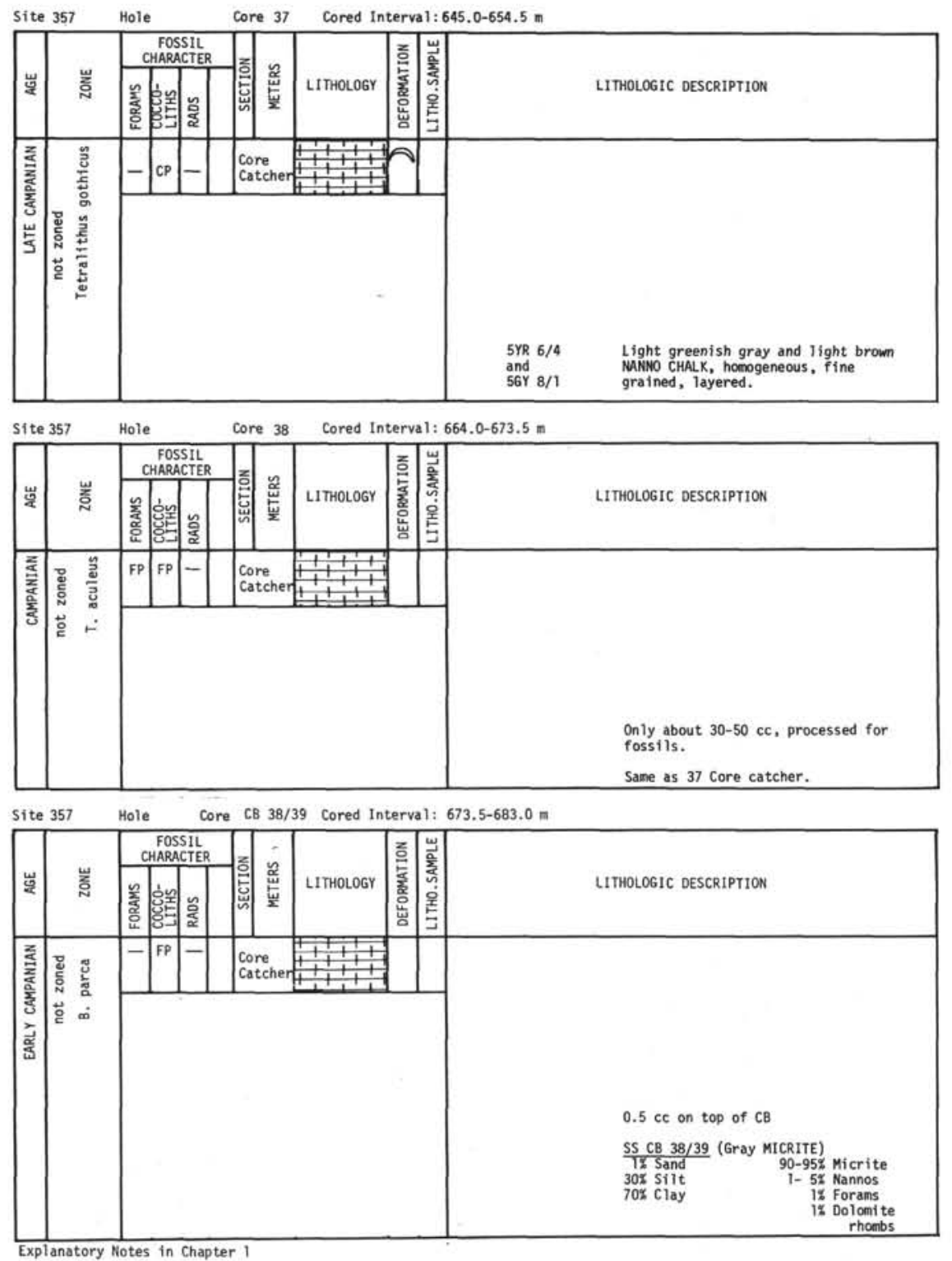


\begin{tabular}{|c|c|c|c|c|c|c|c|c|c|c|}
\hline \multicolumn{2}{|c|}{ Site 357} & \multicolumn{2}{|l|}{ Hole } & \multicolumn{2}{|c|}{ core 39} & \multicolumn{4}{|c|}{ Cored Interva1: $683.0-692.5 \mathrm{~m}$} & \\
\hline \multirow[b]{2}{*}{ 岁 } & \multirow[b]{2}{*}{ 崖 } & \multicolumn{2}{|c|}{$\begin{array}{l}\text { FOSSIL } \\
\text { CHARACTER } \\
\end{array}$} & \multirow[b]{2}{*}{ 暿 } & \multirow[b]{2}{*}{ 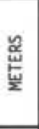 } & \multirow[b]{2}{*}{ LITHOLOGY } & \multirow{2}{*}{ 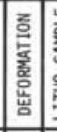 } & \multirow{2}{*}{ 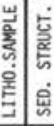 } & \multirow{2}{*}{ LITHOLOGIC DESCRIPTION } & \\
\hline & & & & & & & & & & \\
\hline & & & & 0 & & & & & & \\
\hline 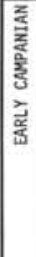 & 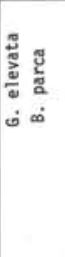 & $-a$ & & 1 & & 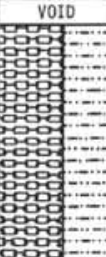 & & & $5 Y 4 / 1$ & 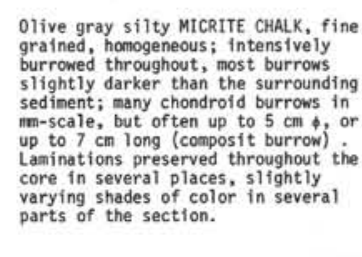 \\
\hline
\end{tabular}

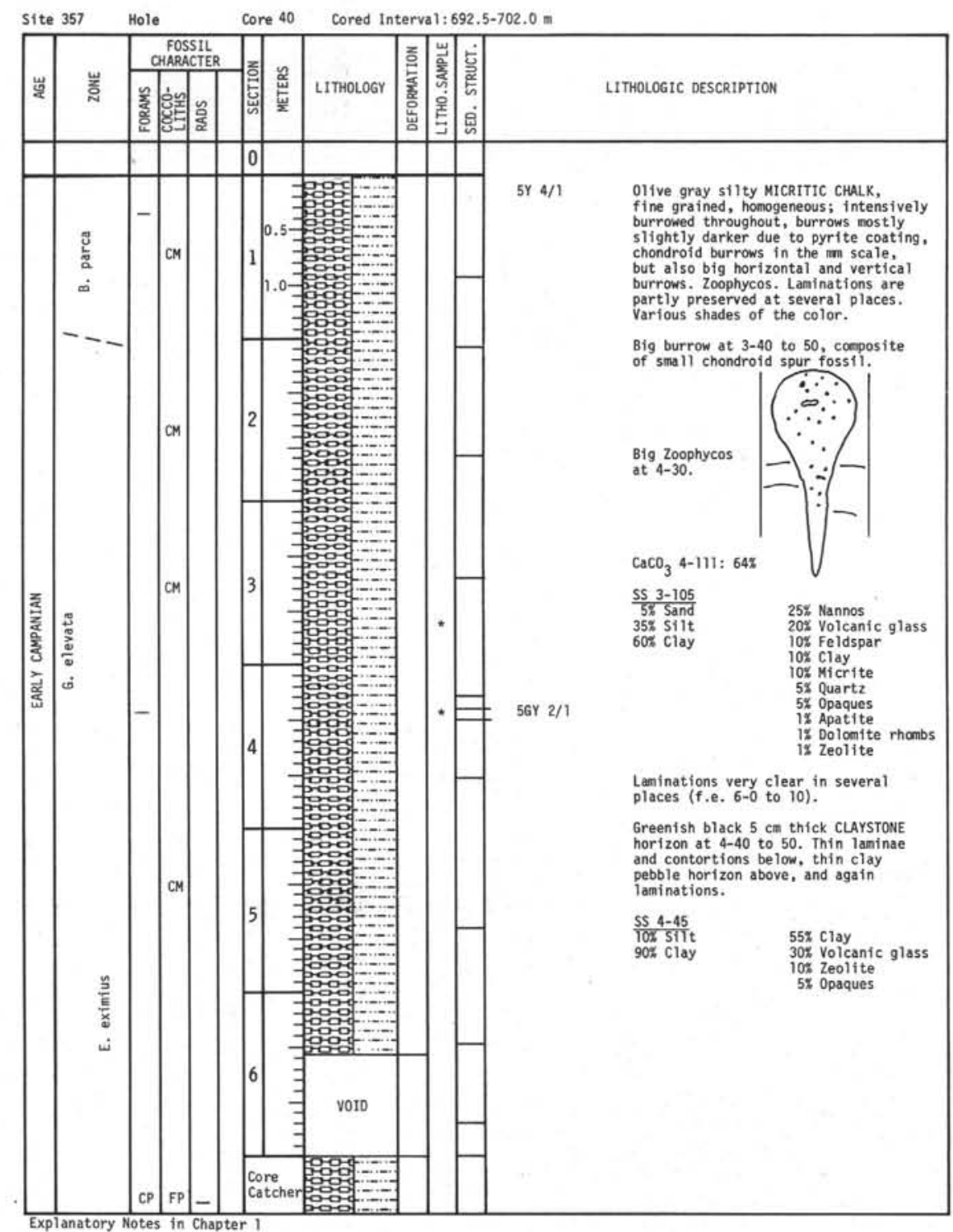



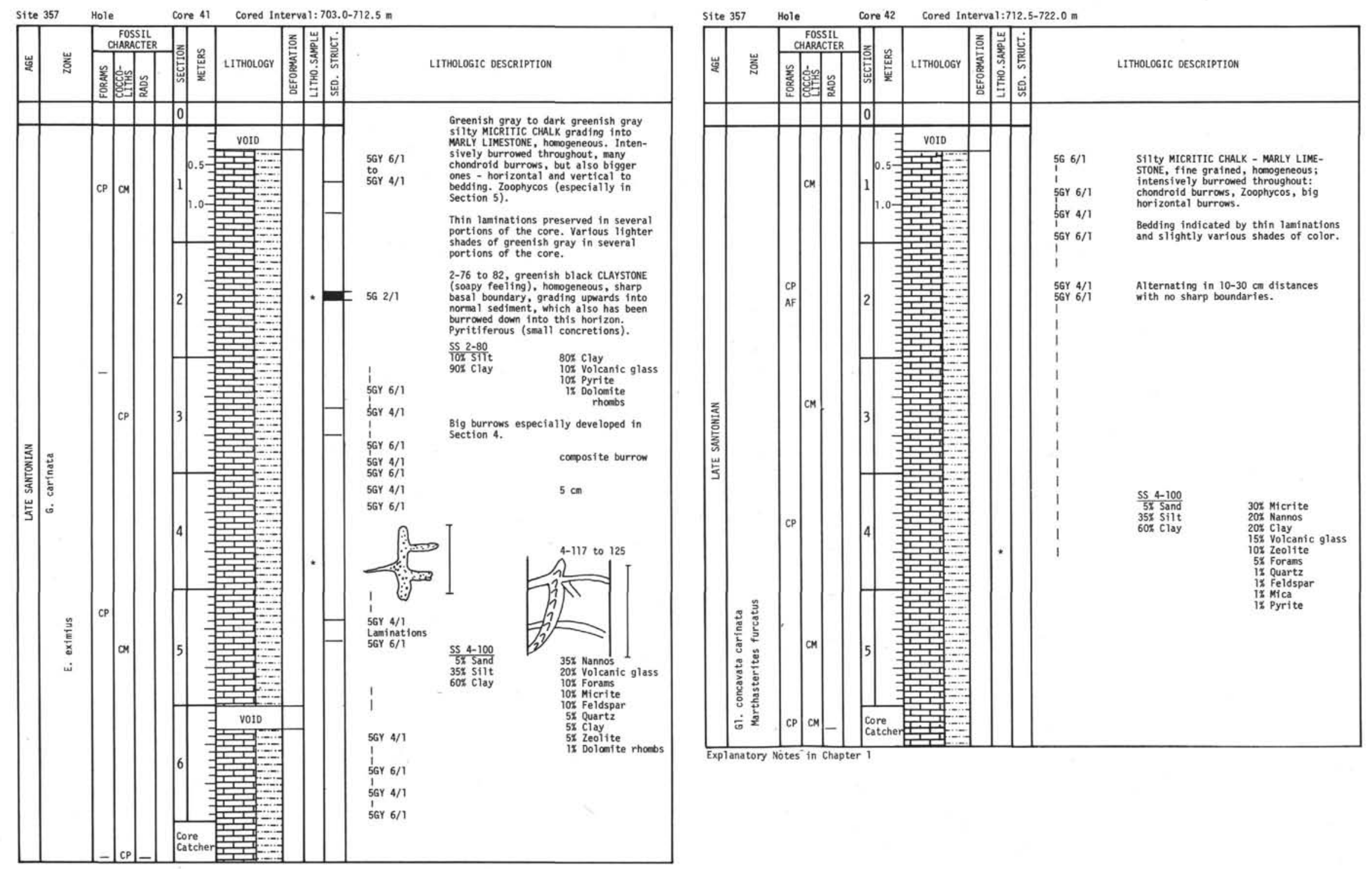

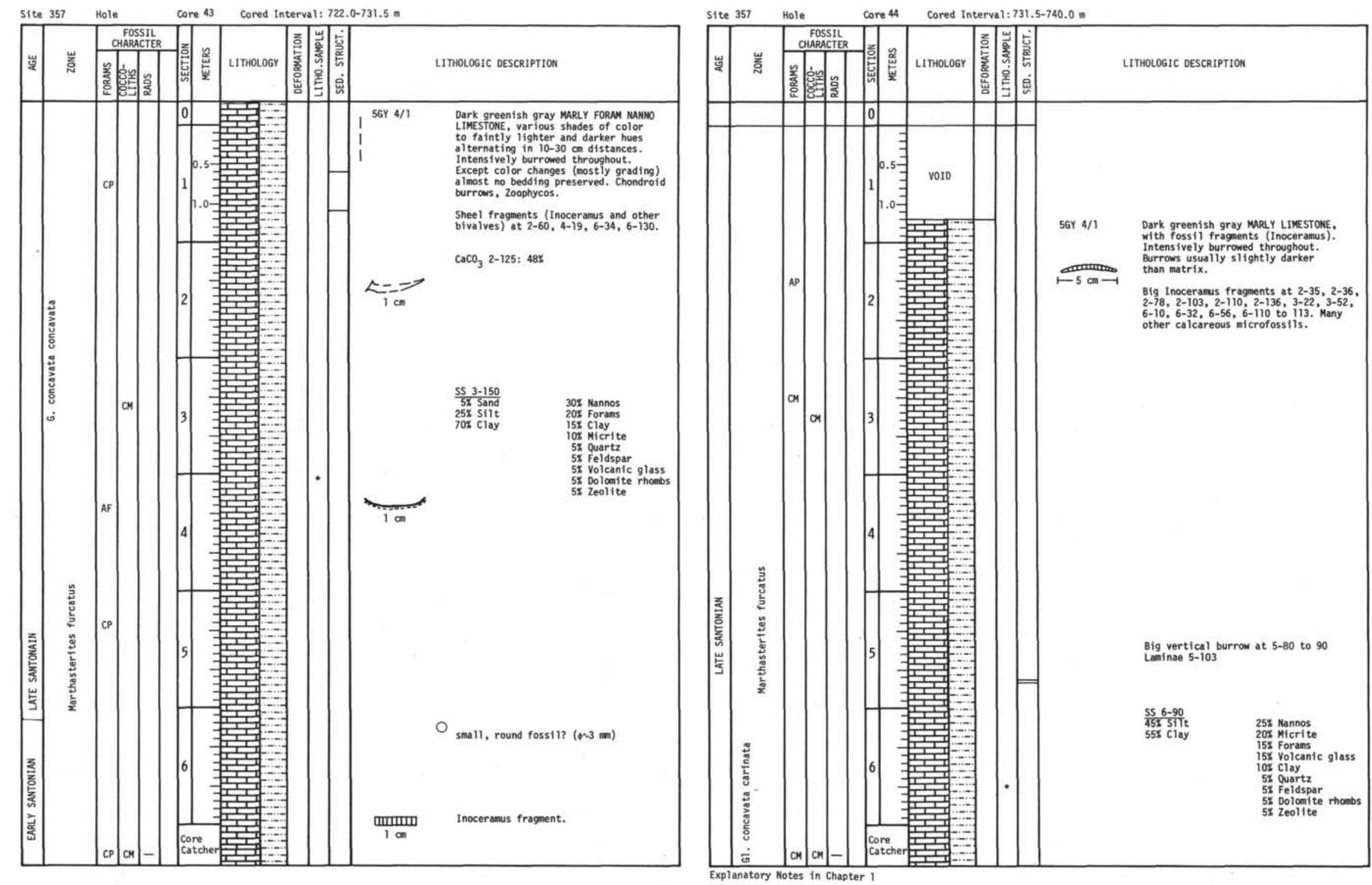


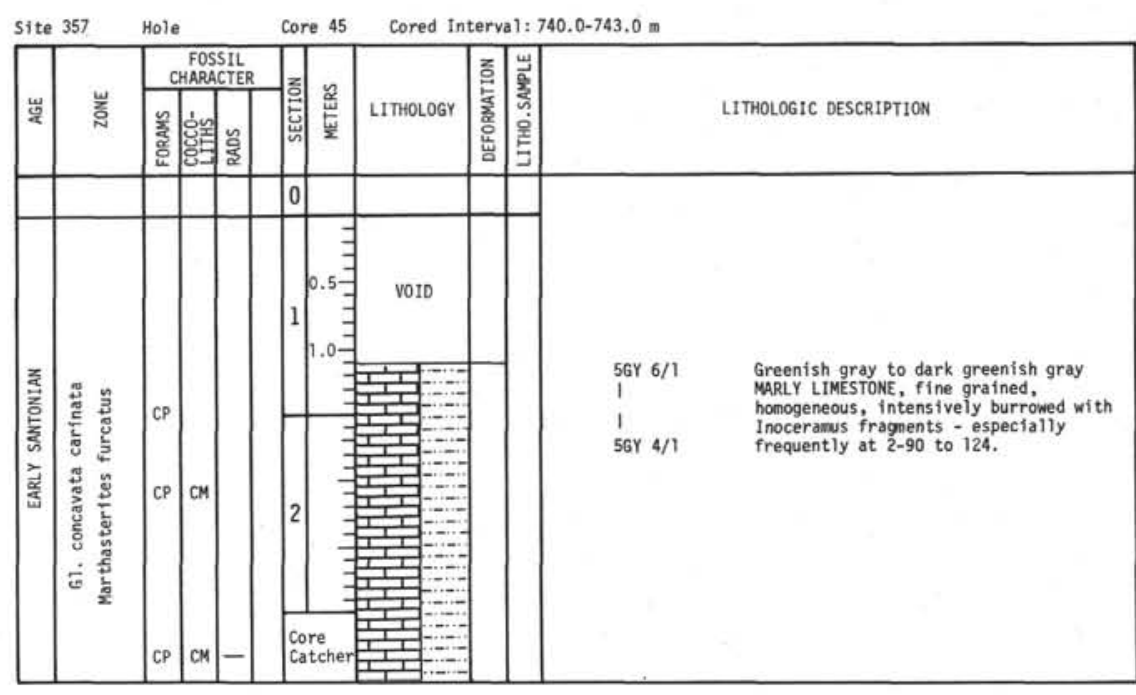

Site 357

Core 46 Cored Interval: $743.0-749.5 \mathrm{~m}$

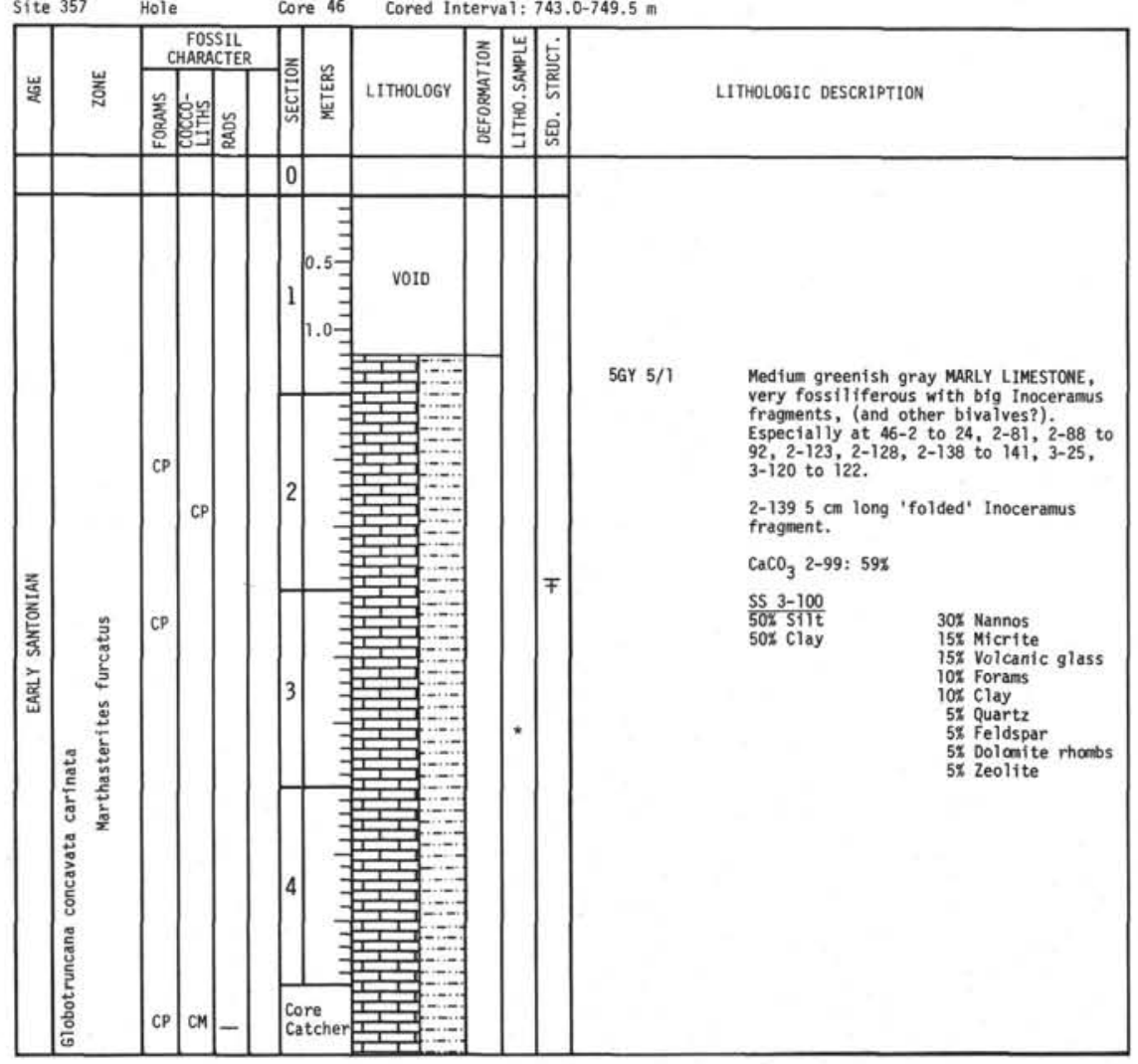

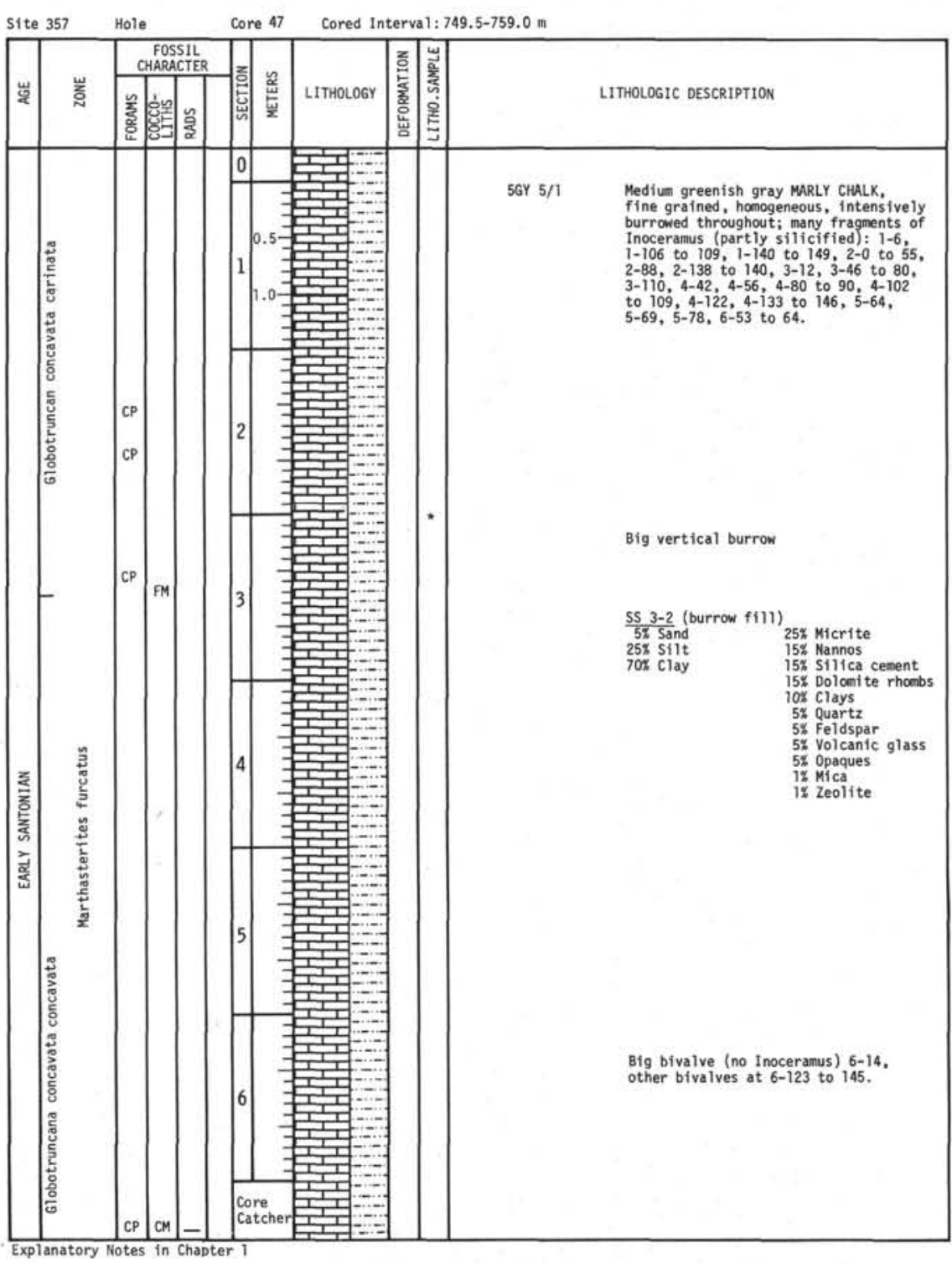



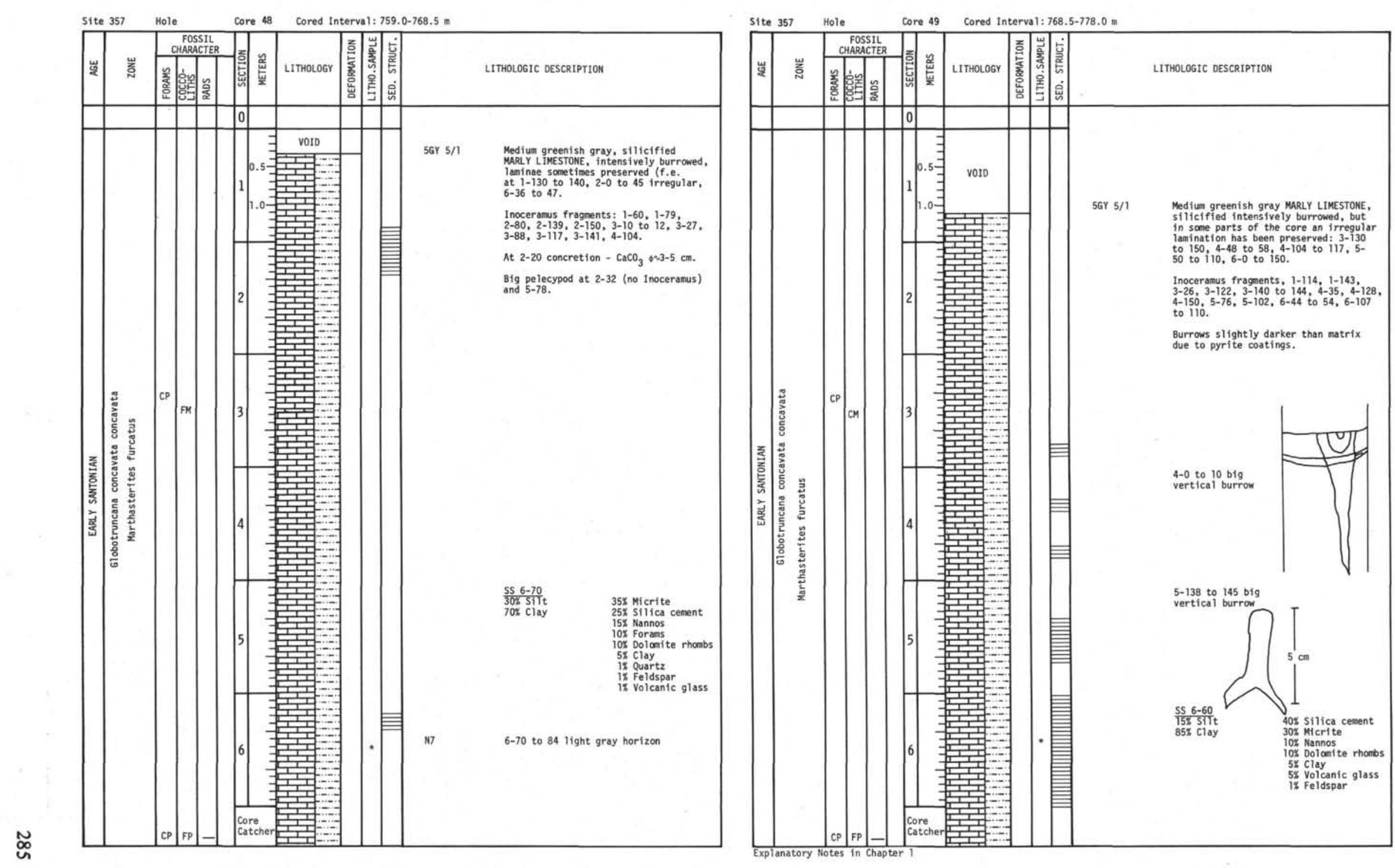

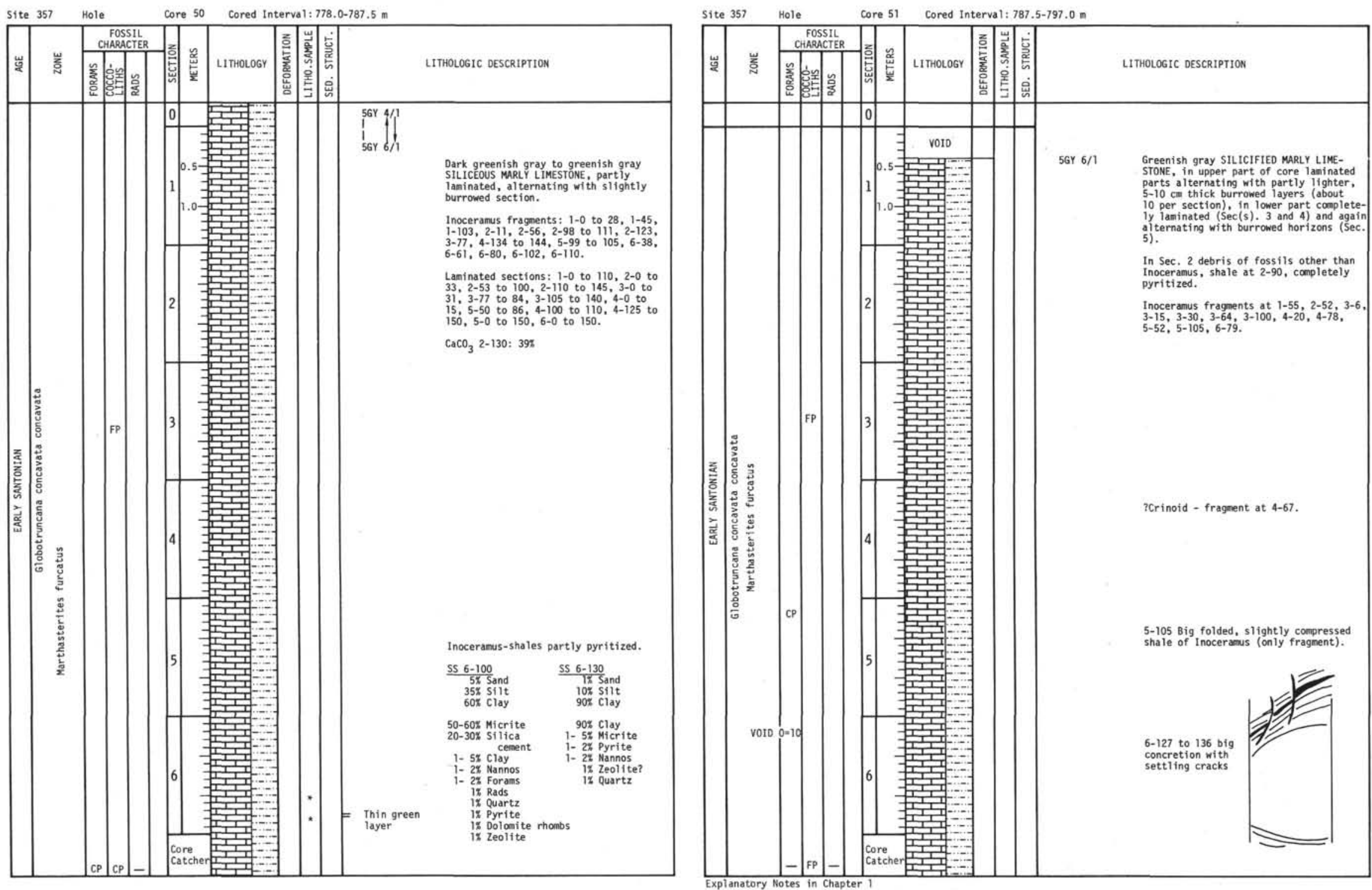


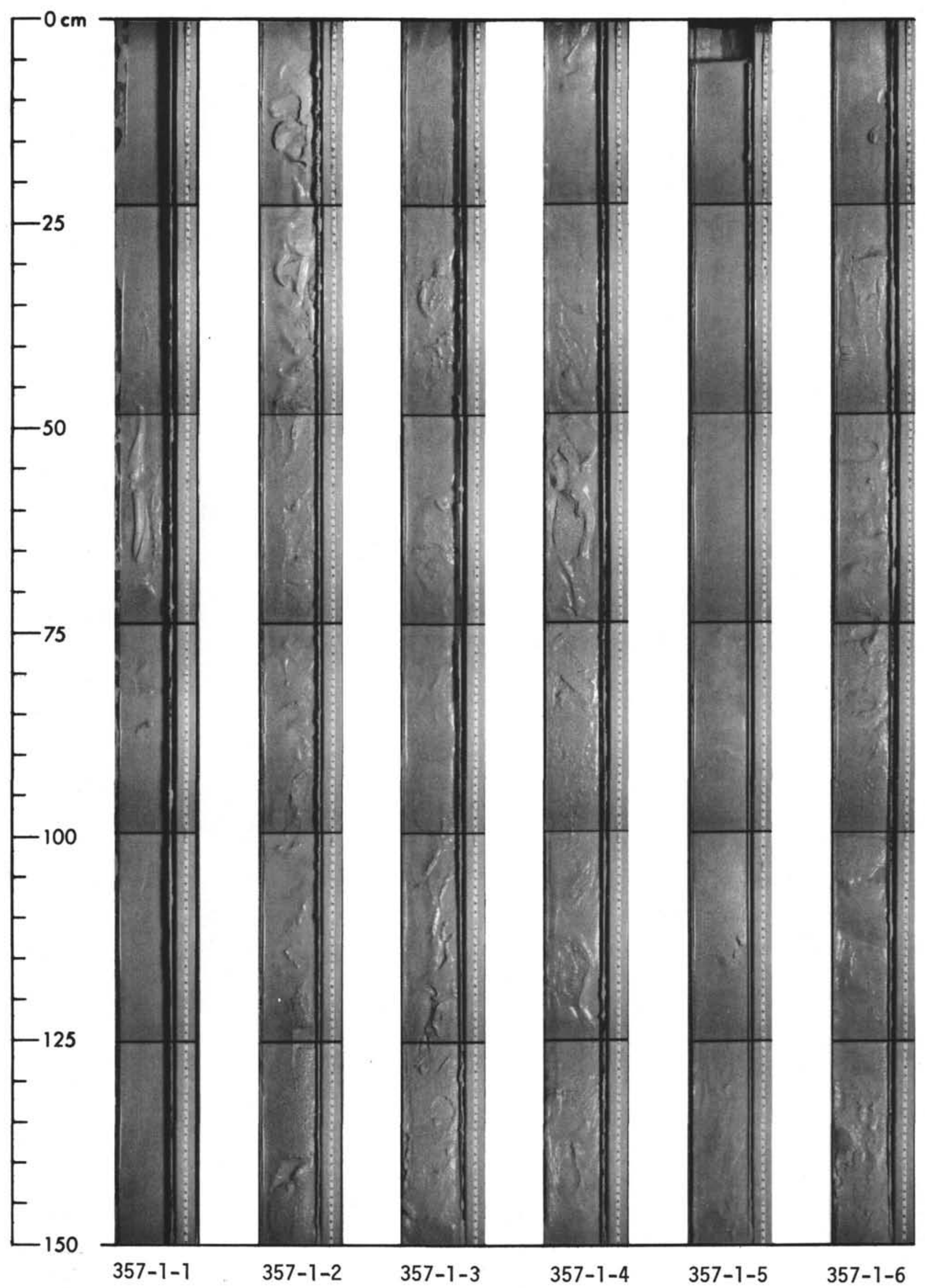




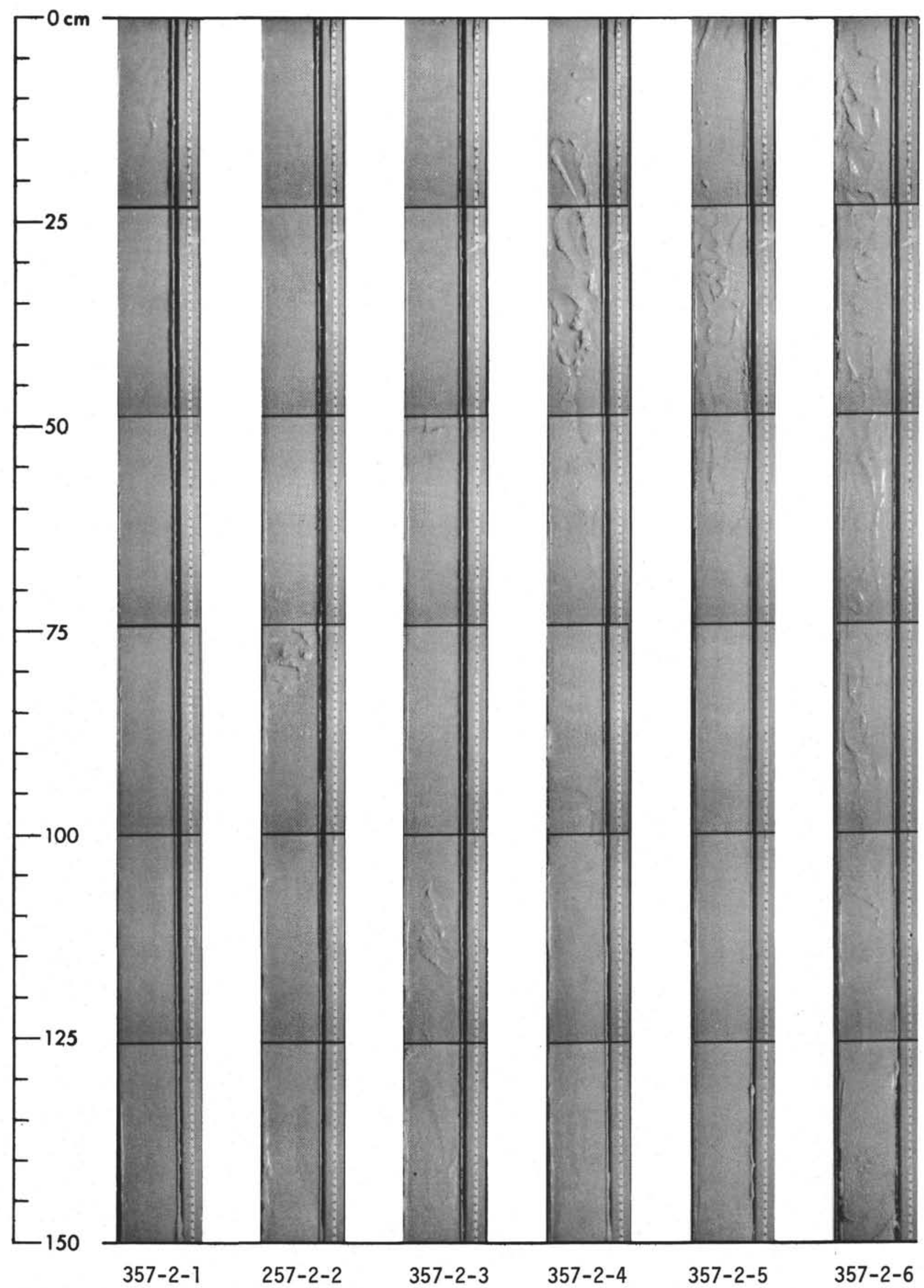


SITE 357: RIO GRANDE RISE

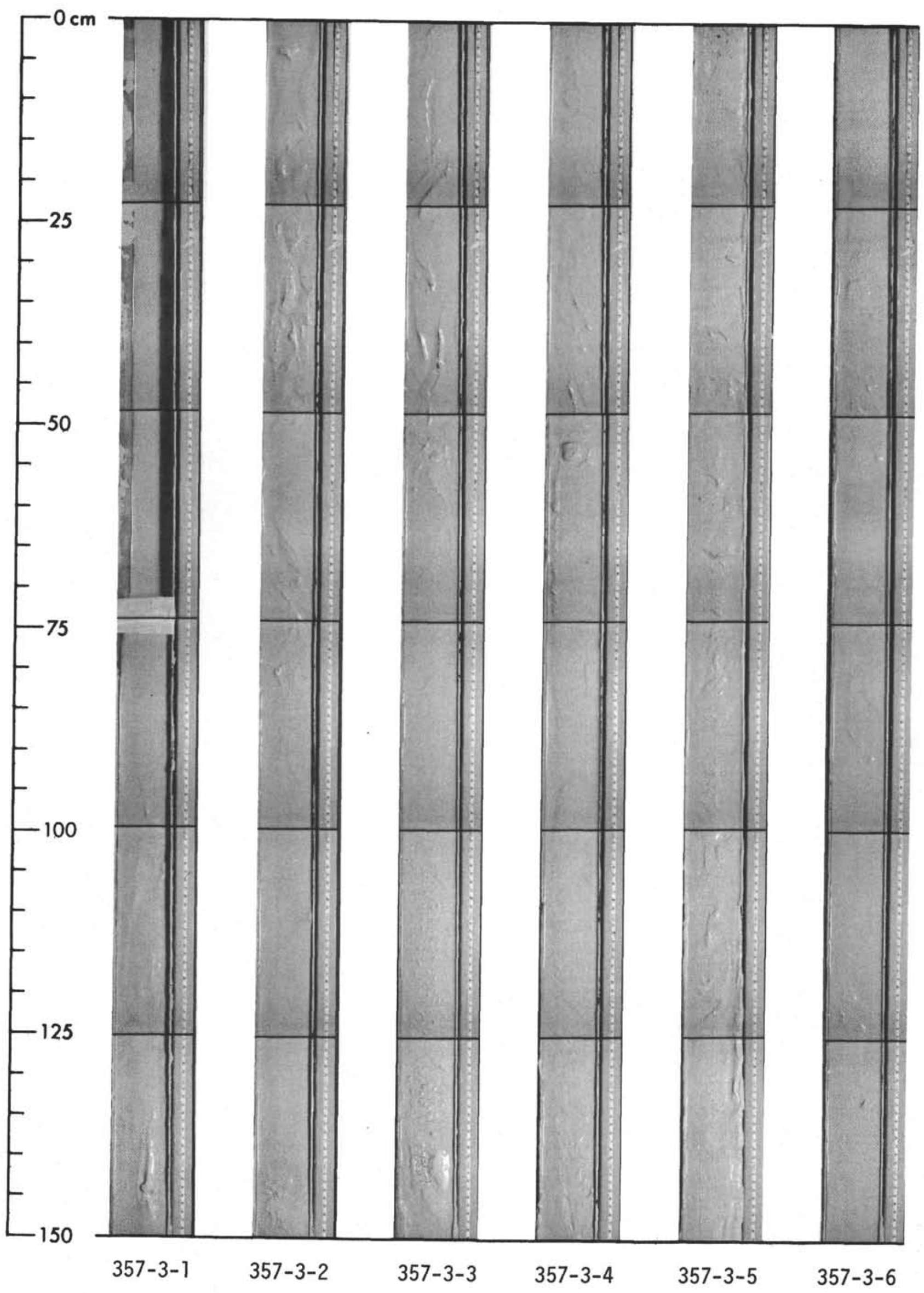


SITE 357: RIO GRANDE RISE

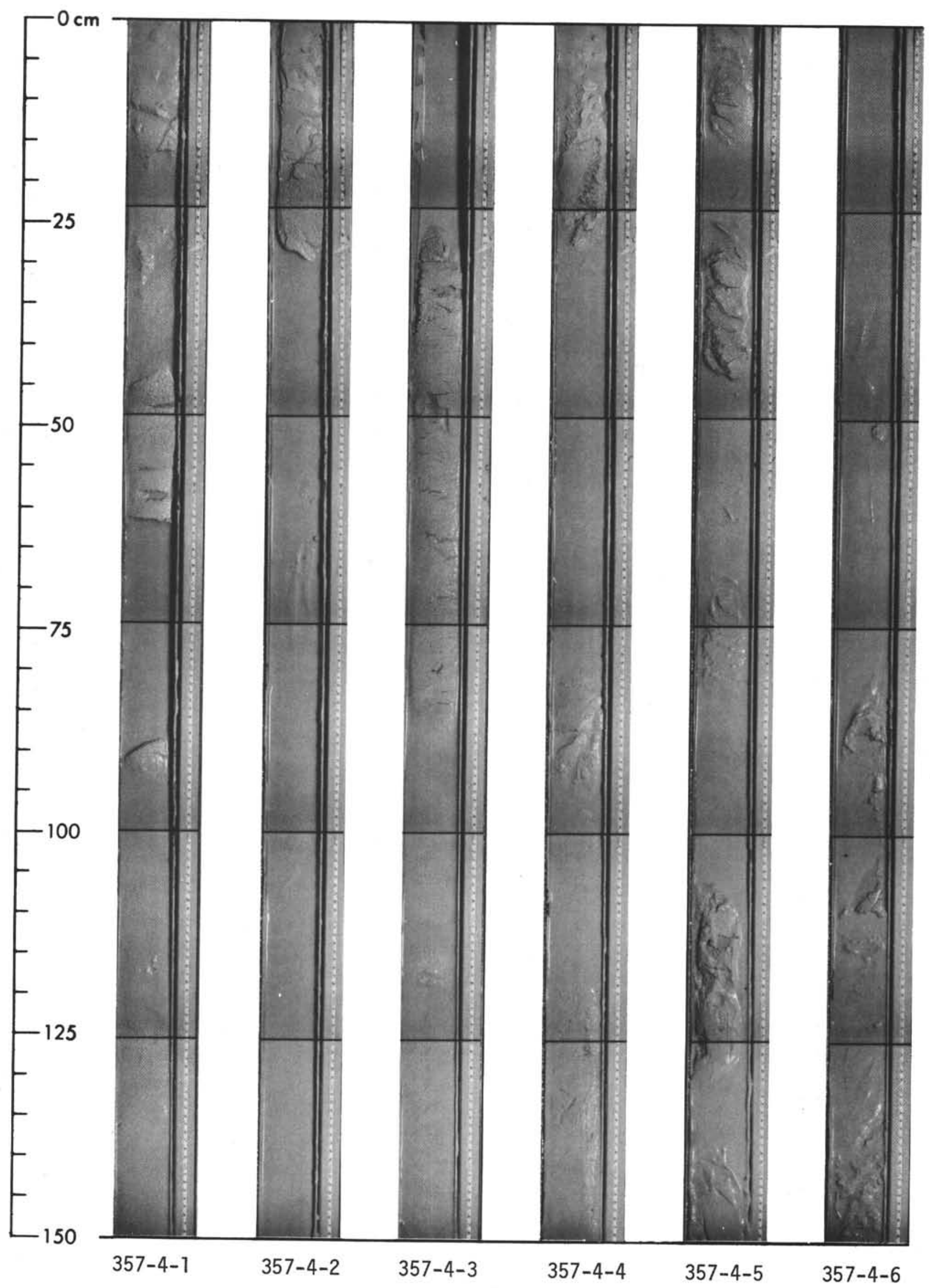


SITE 357: RIO GRANDE RISE

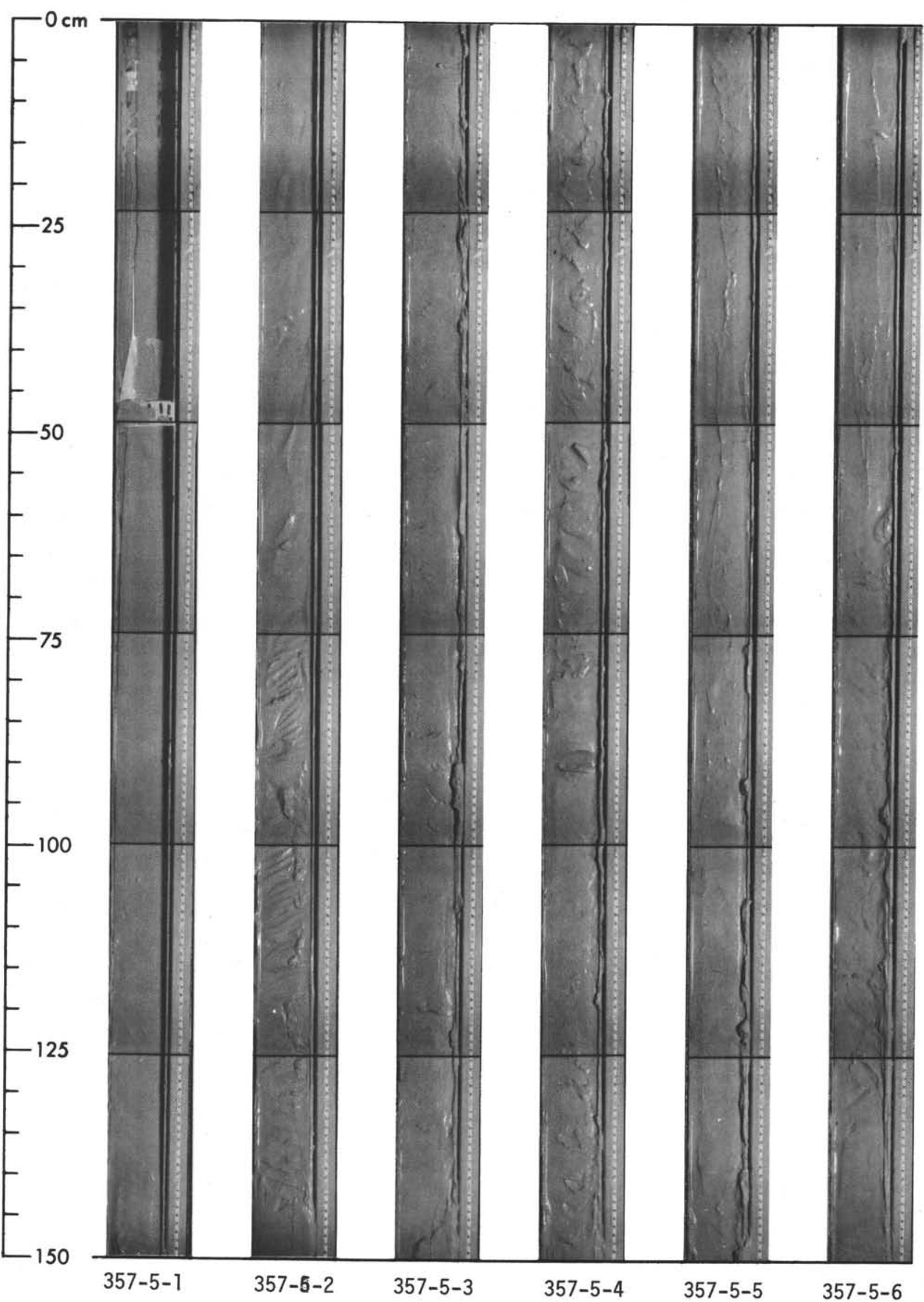


SITE 357: RIO GRANDE RISE

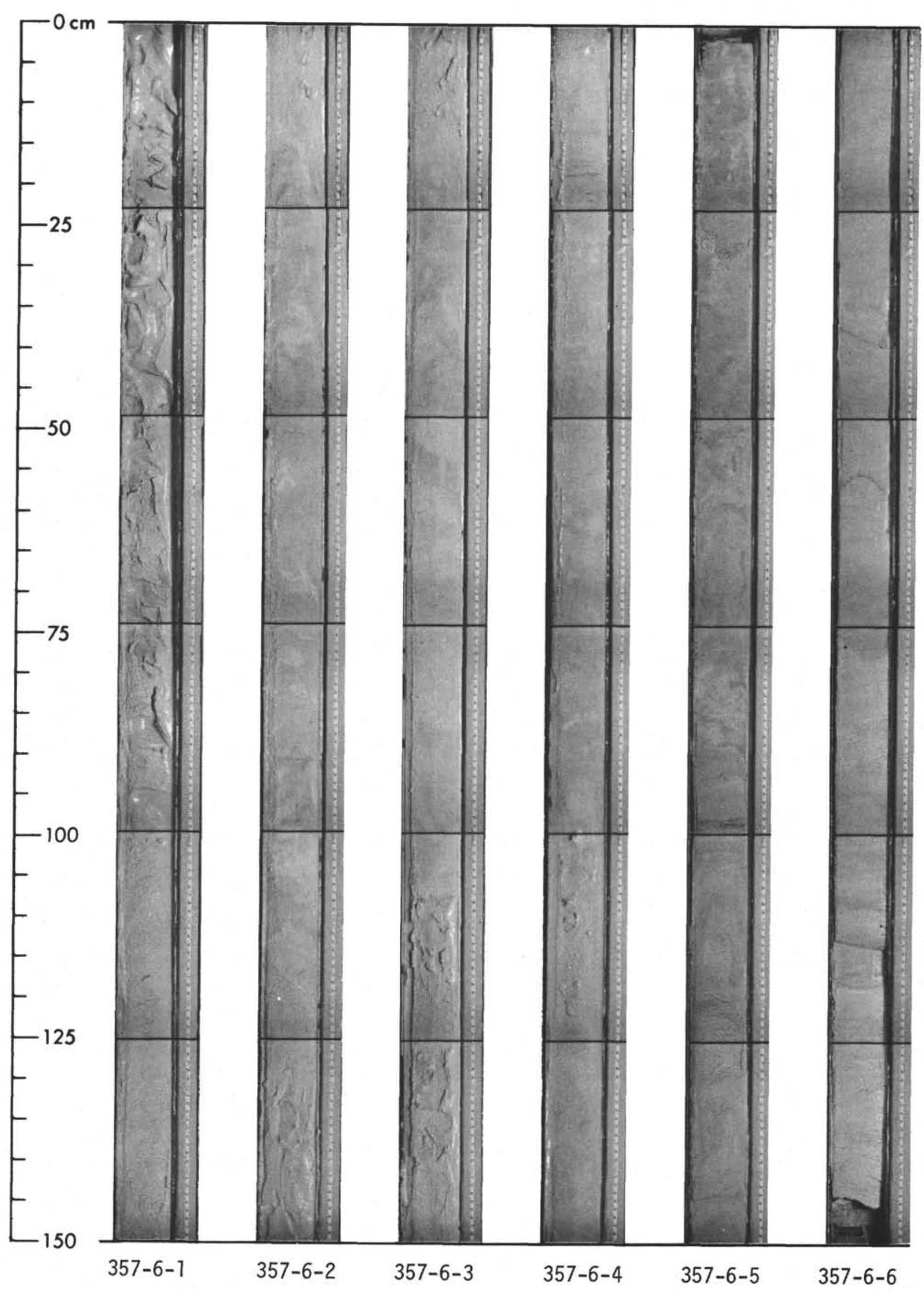




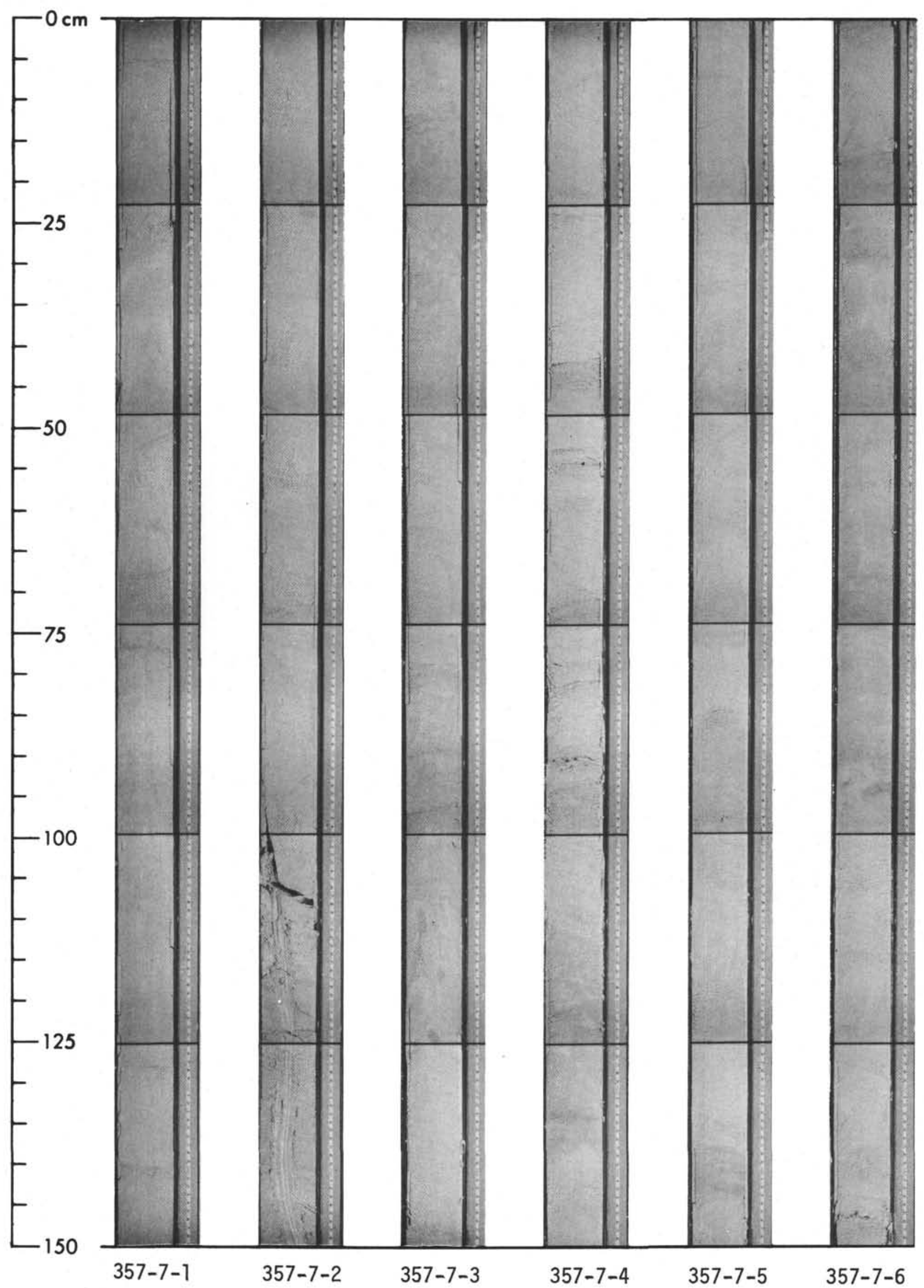


SITE 357: RIO GRANDE RISE

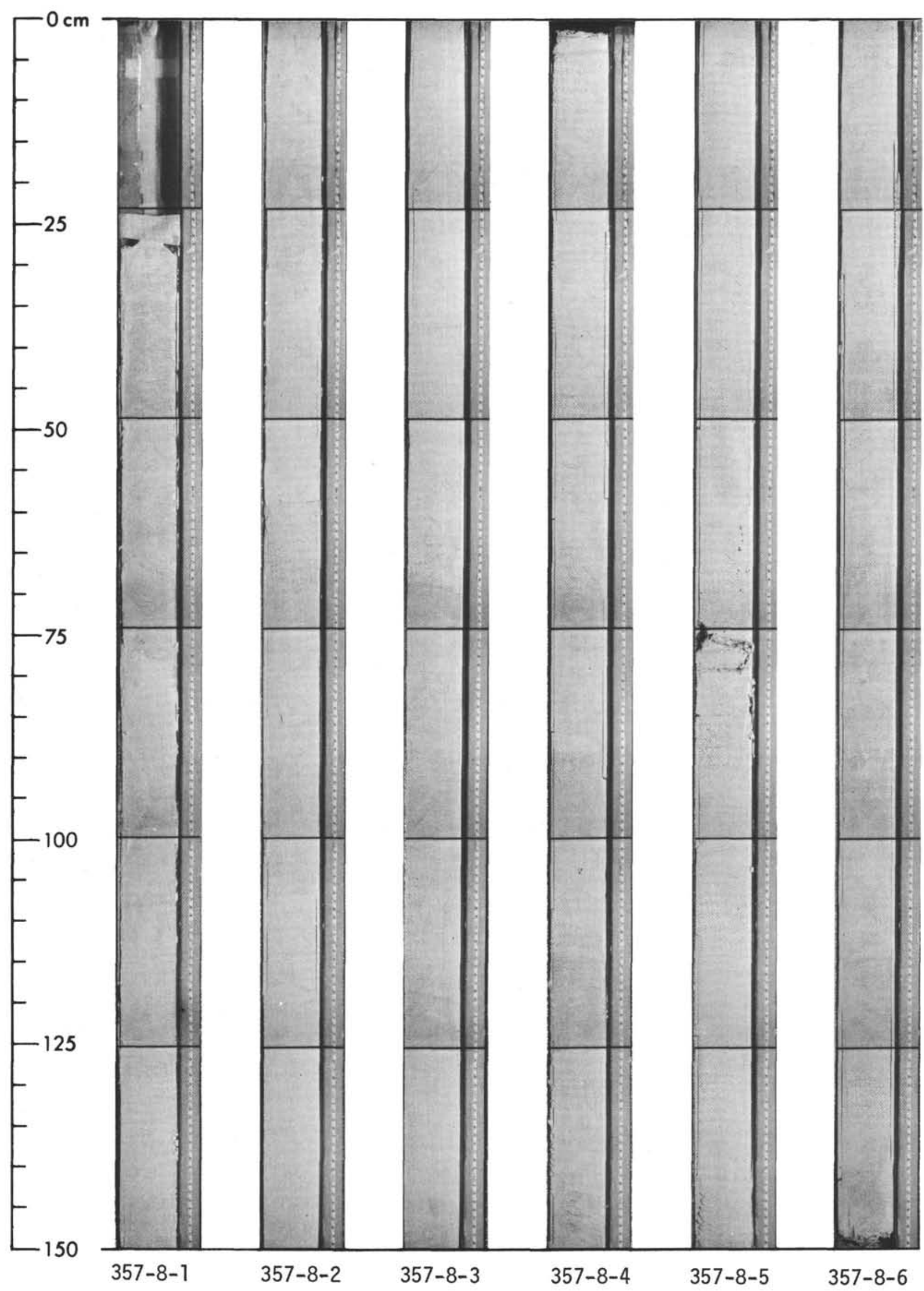




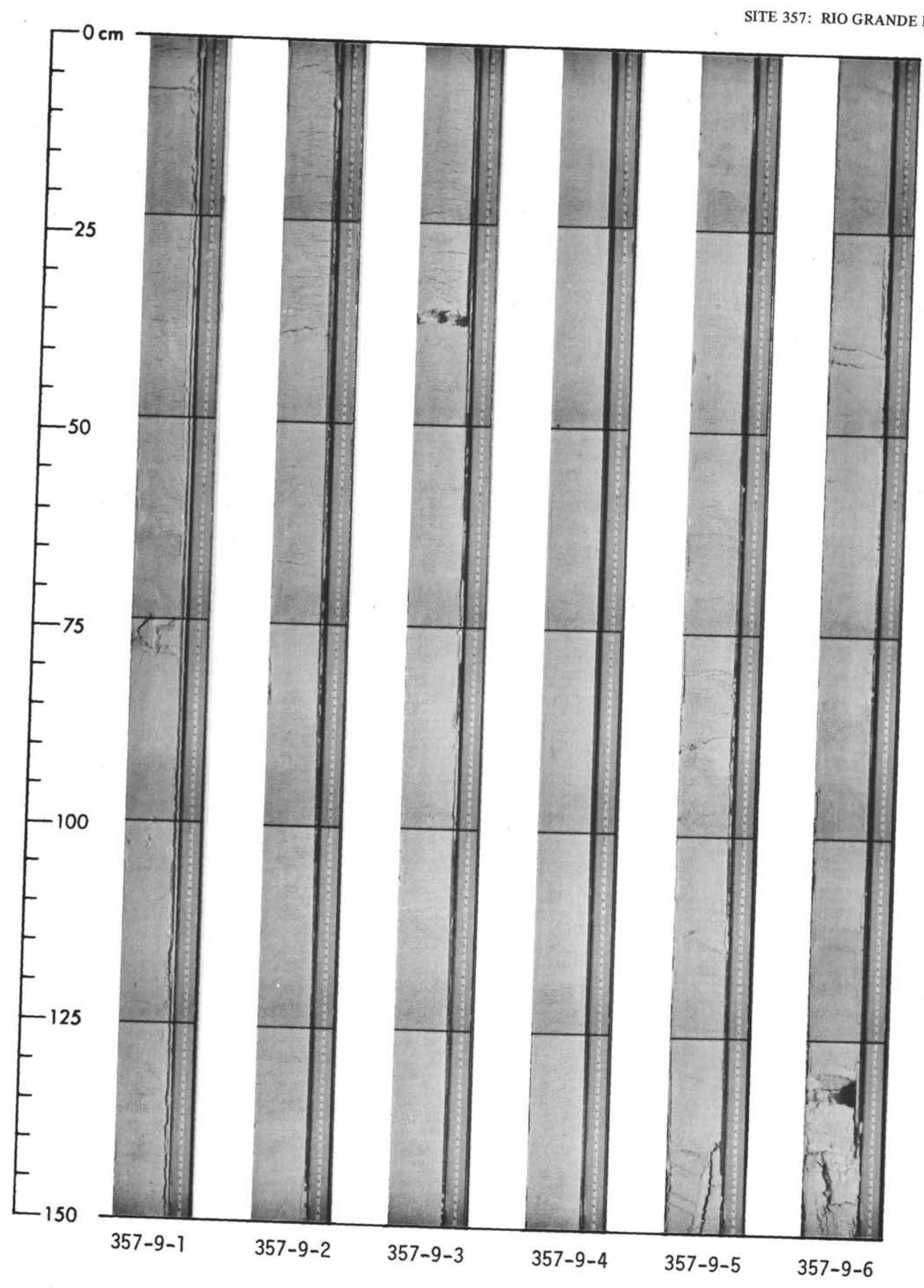


SITE 357: RIO GRANDE RISE

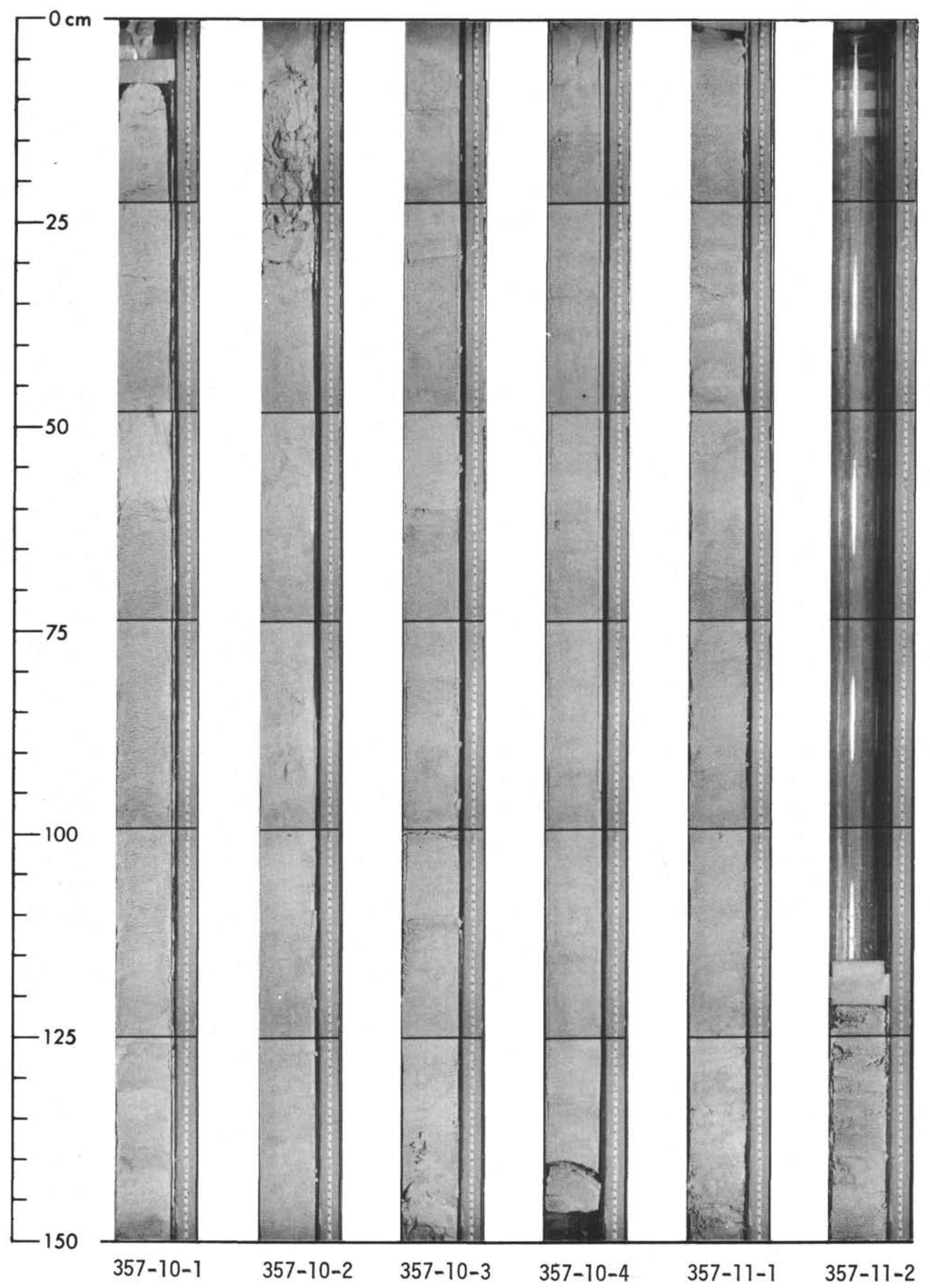




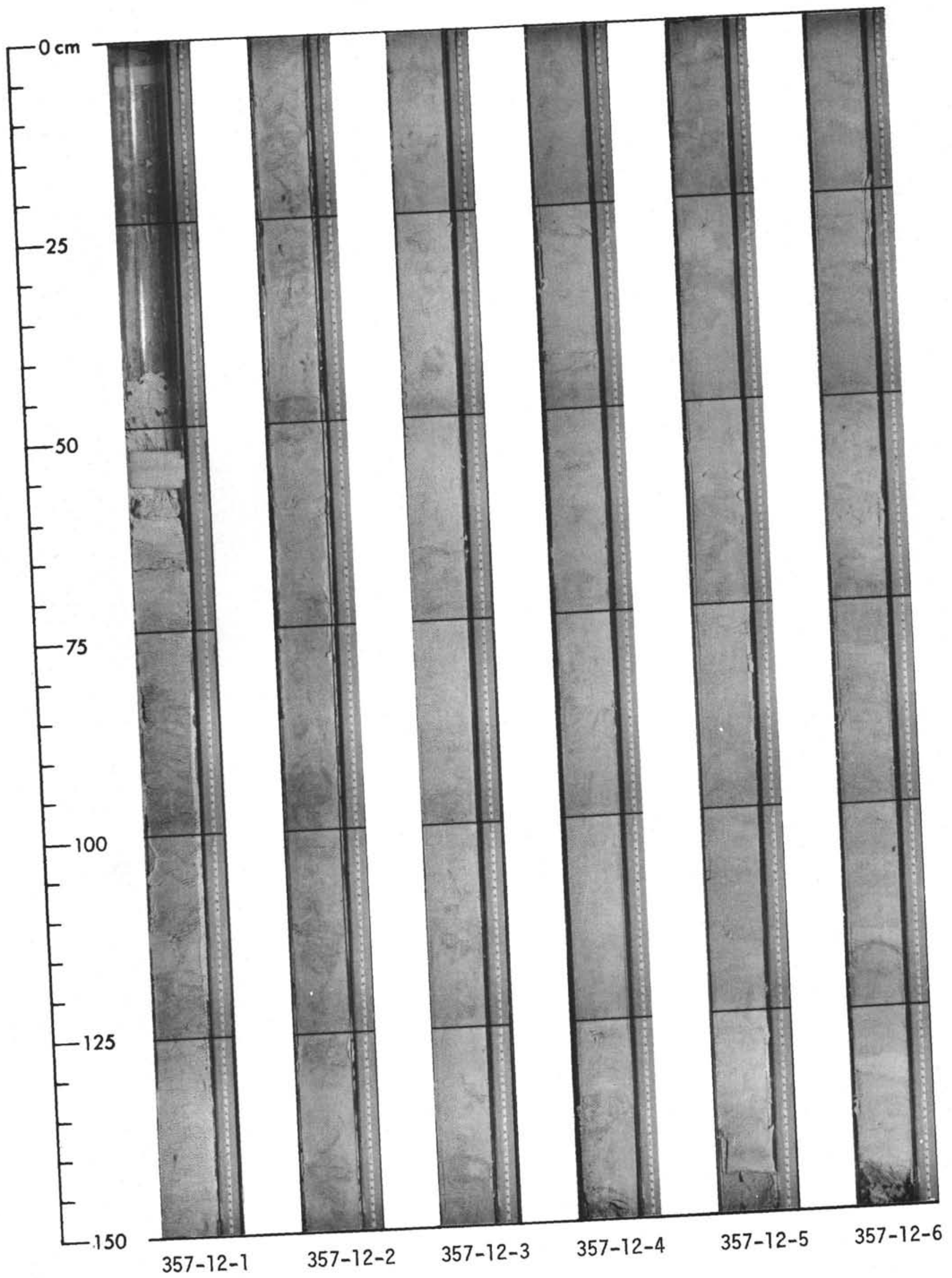




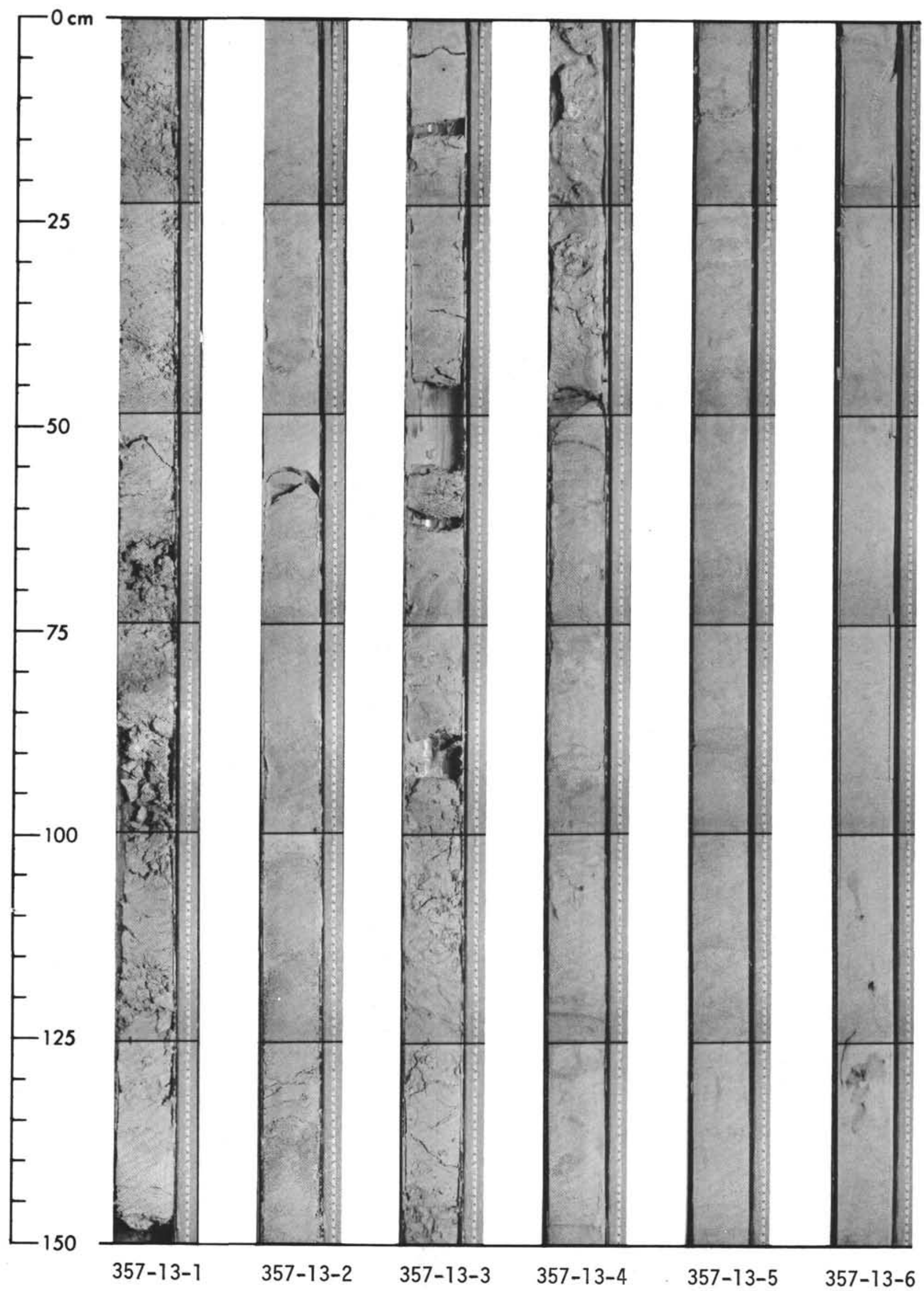


SITE 357: RIO GRANDE RISE

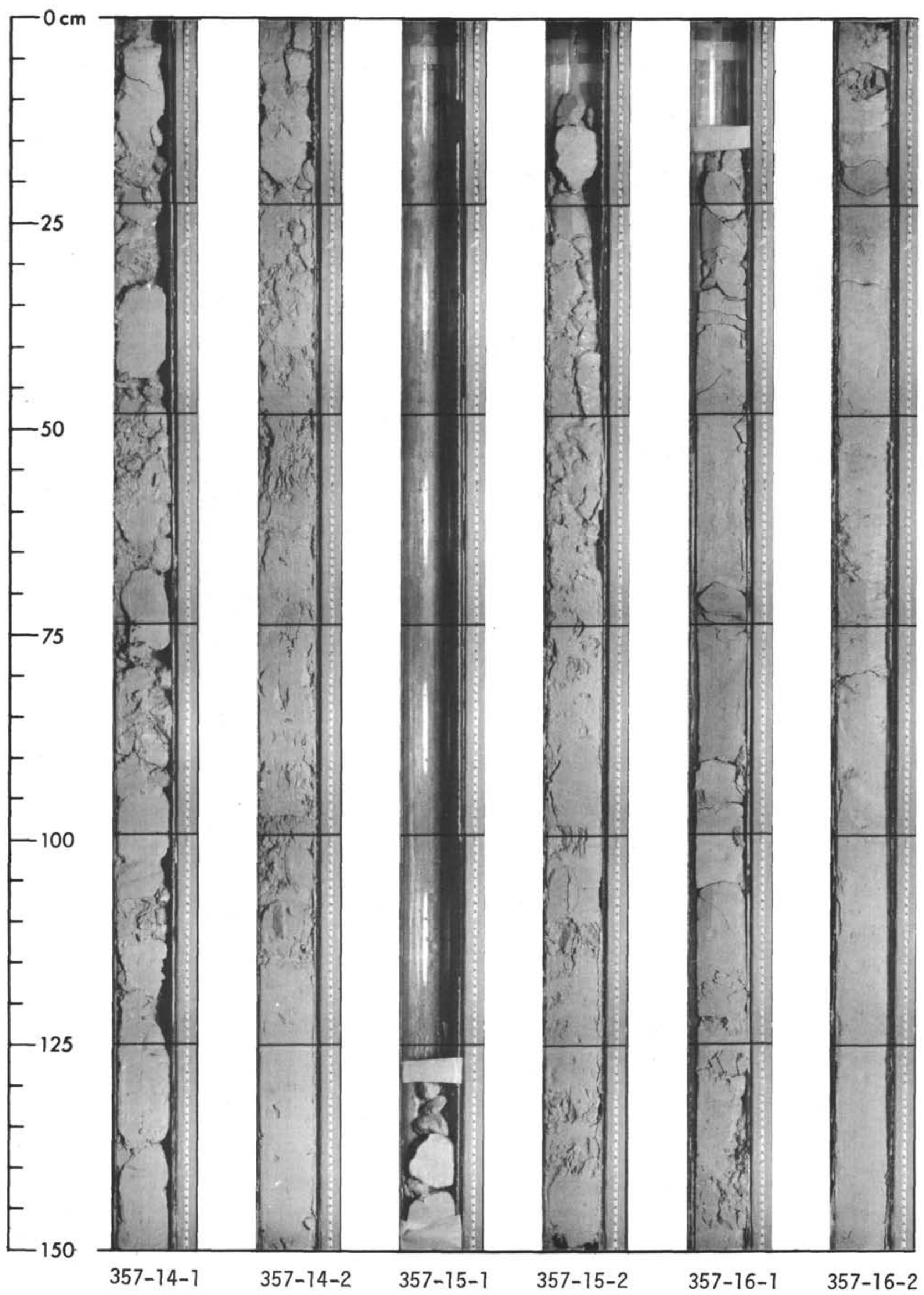




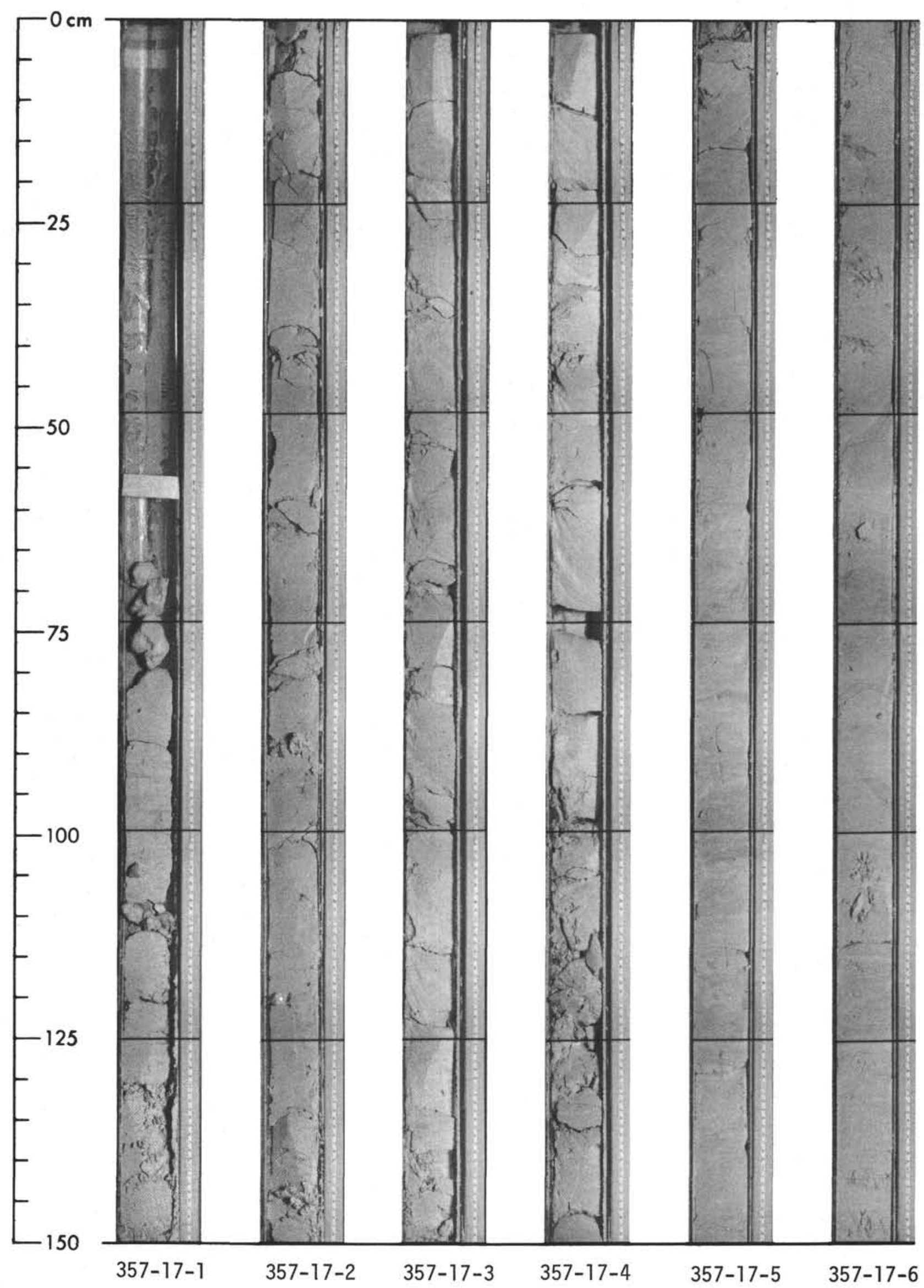




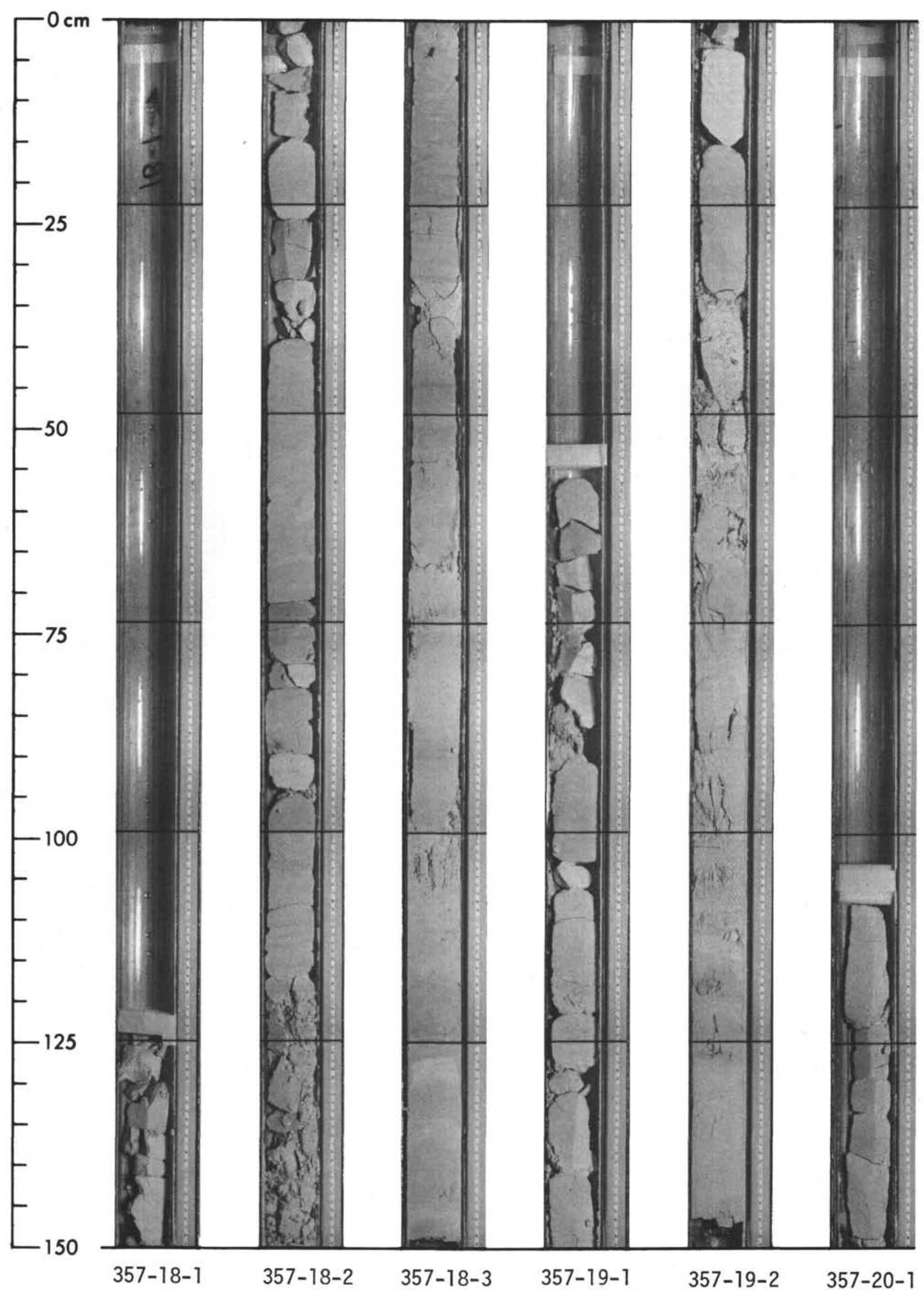




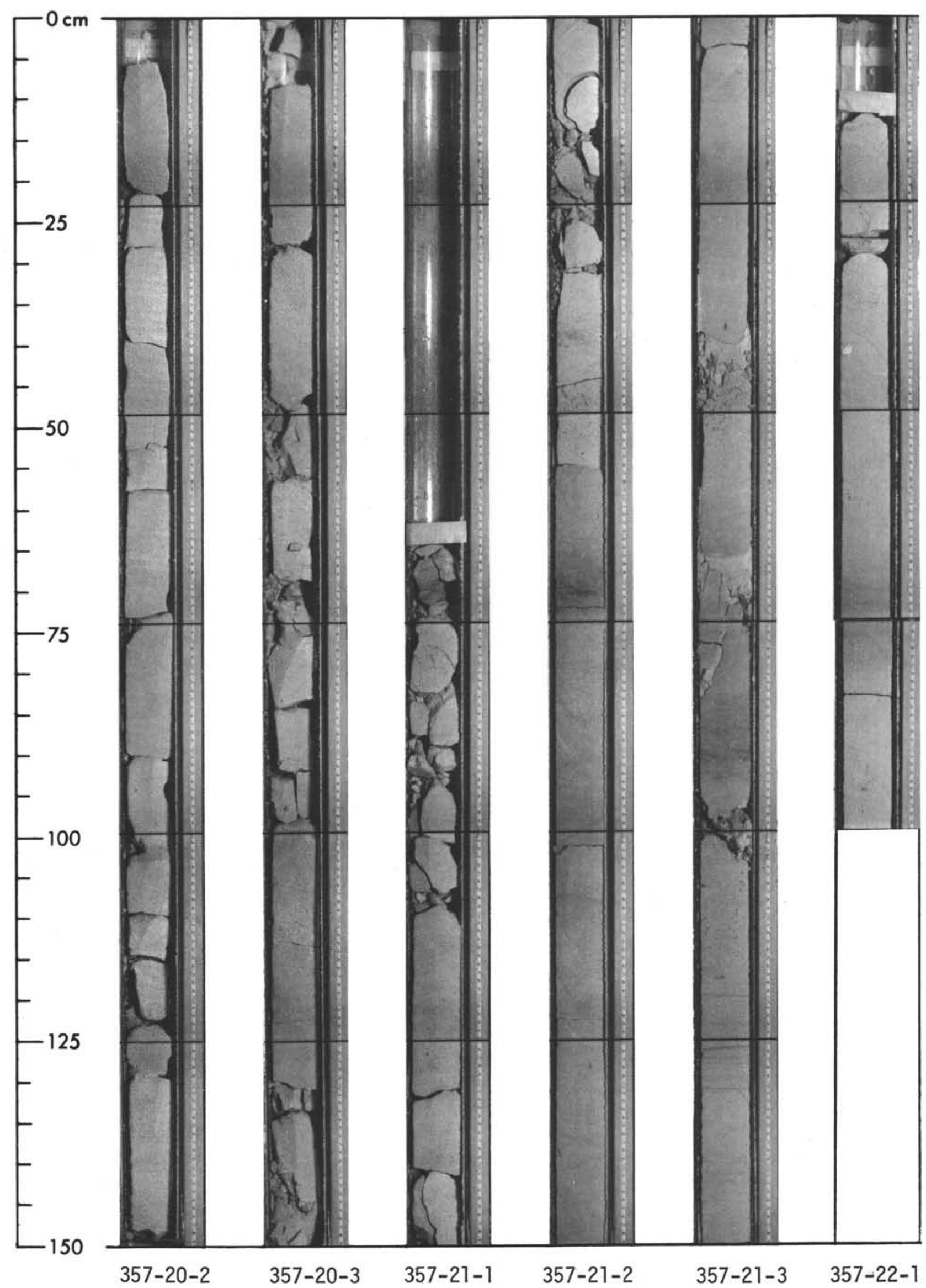


SITE 357: RIO GRANDE RISE

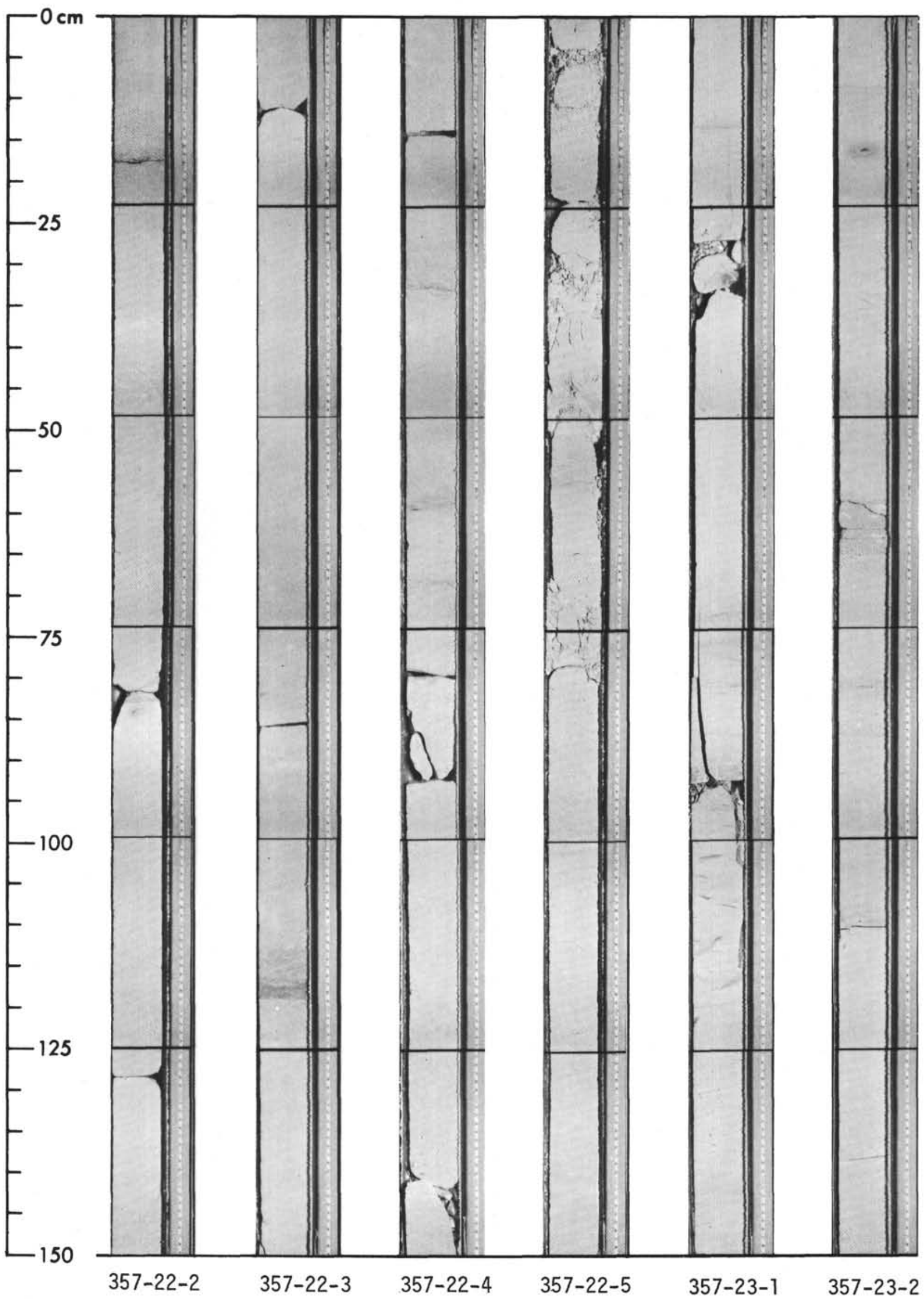


SITE 357: RIO GRANDE RISE

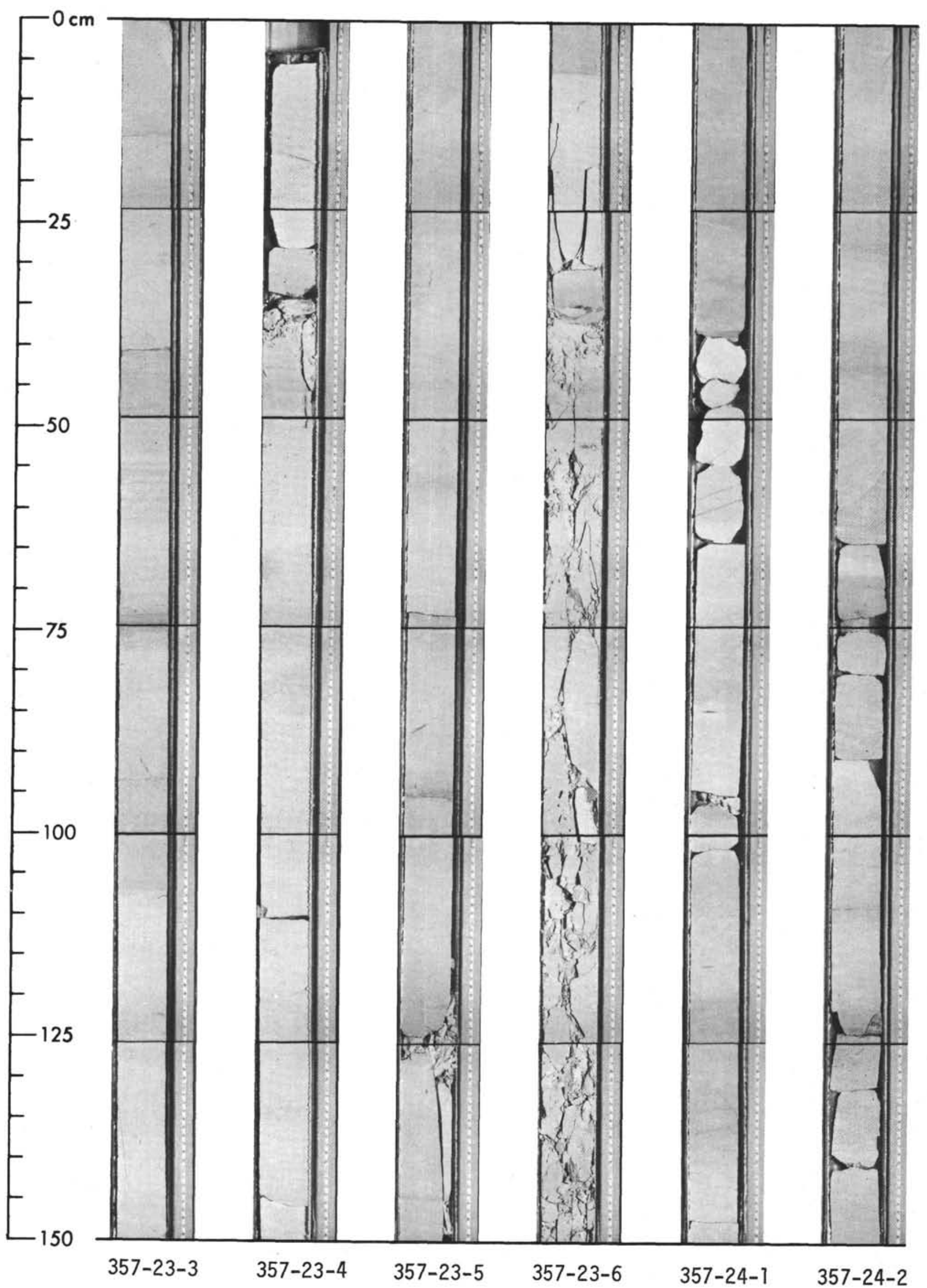




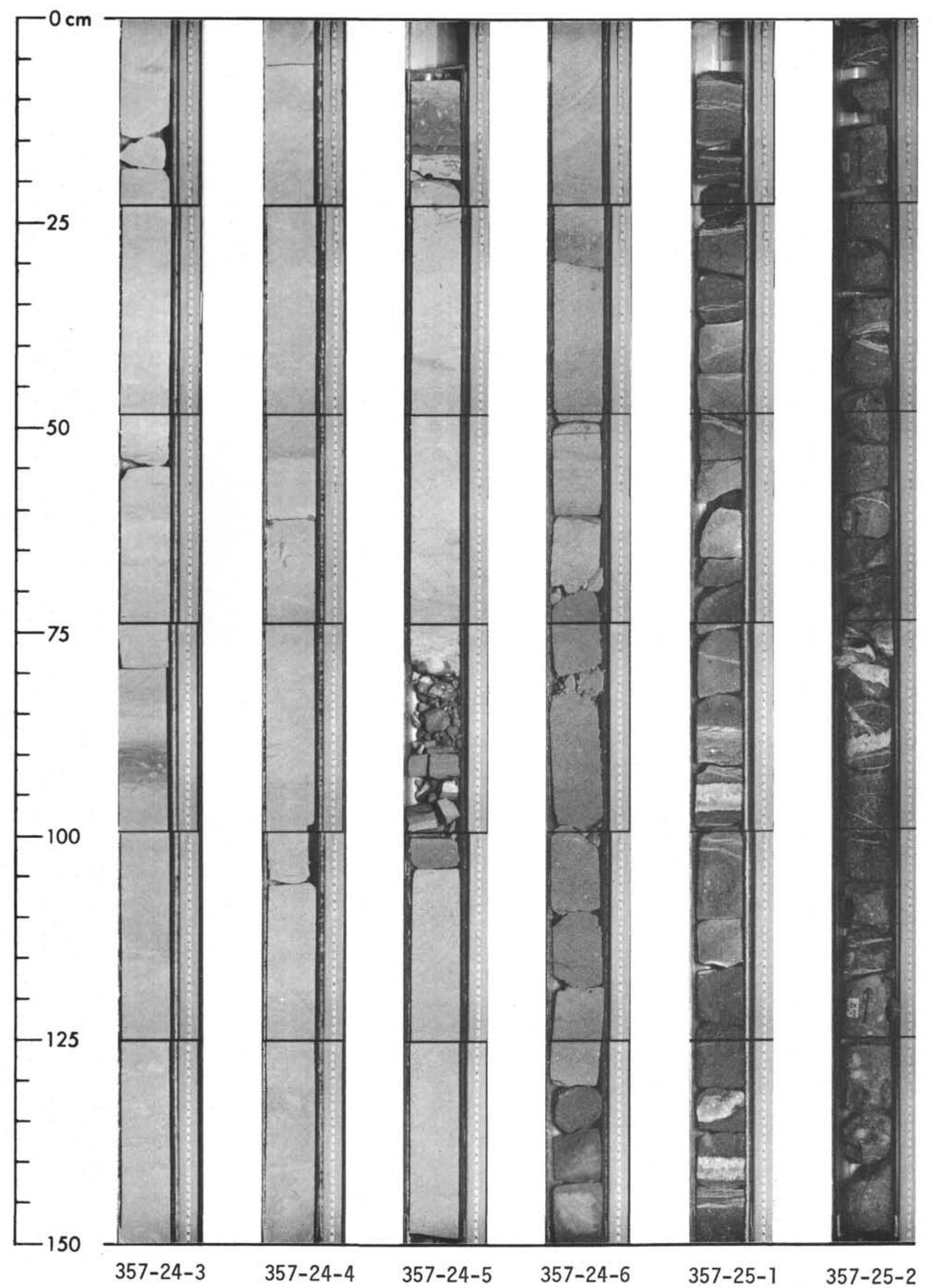


SITE 357: RIO GRANDE RISE

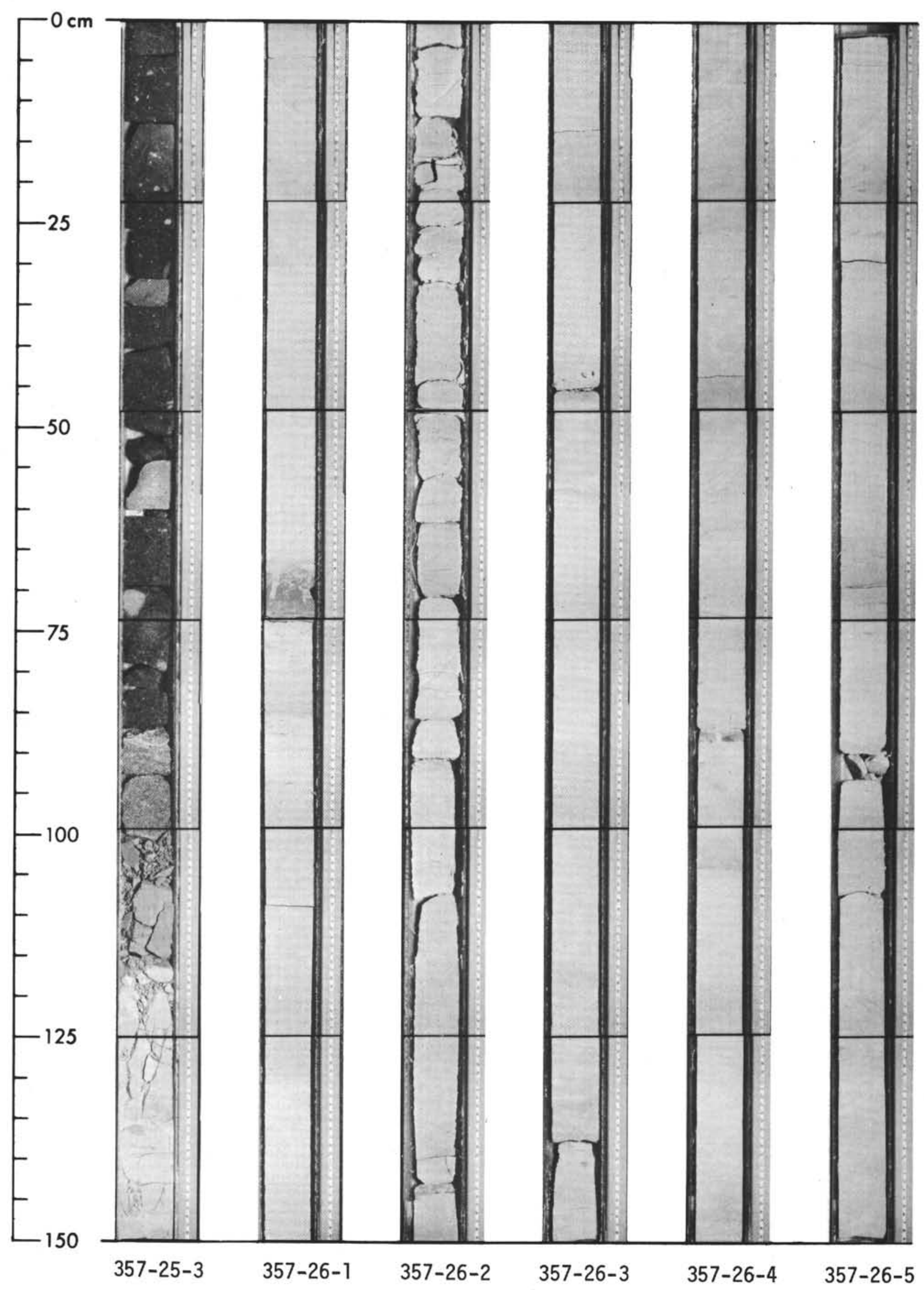




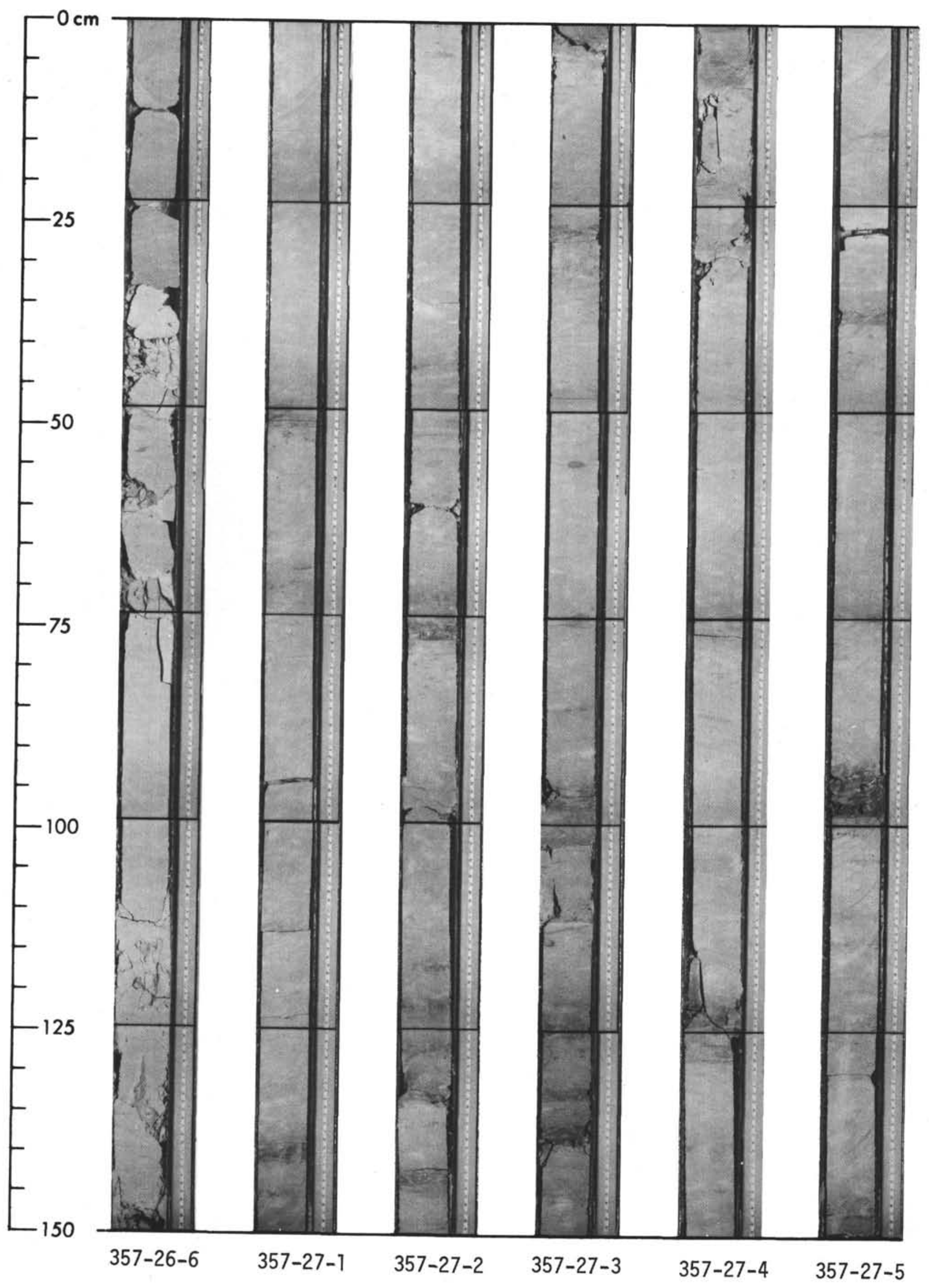




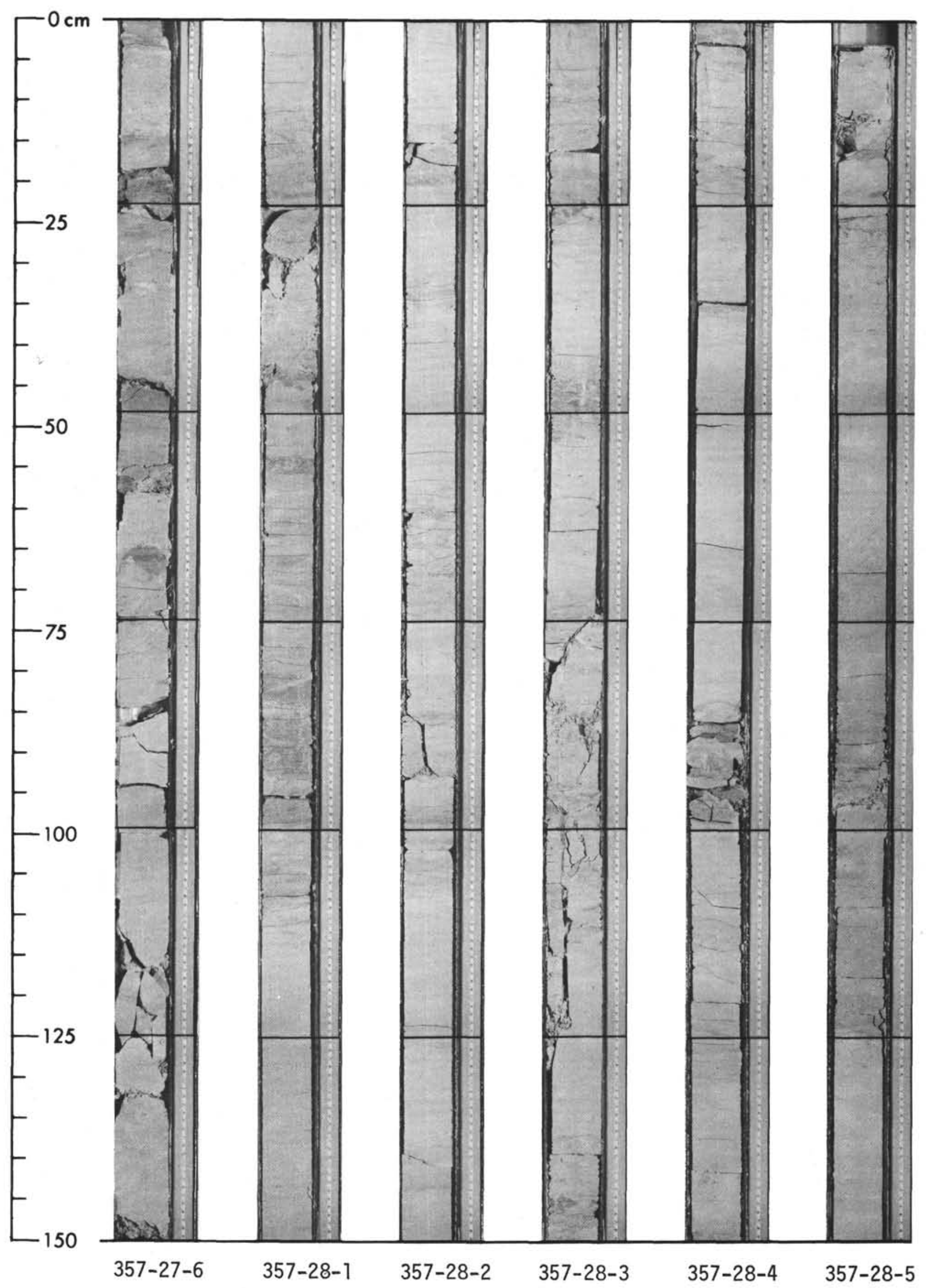




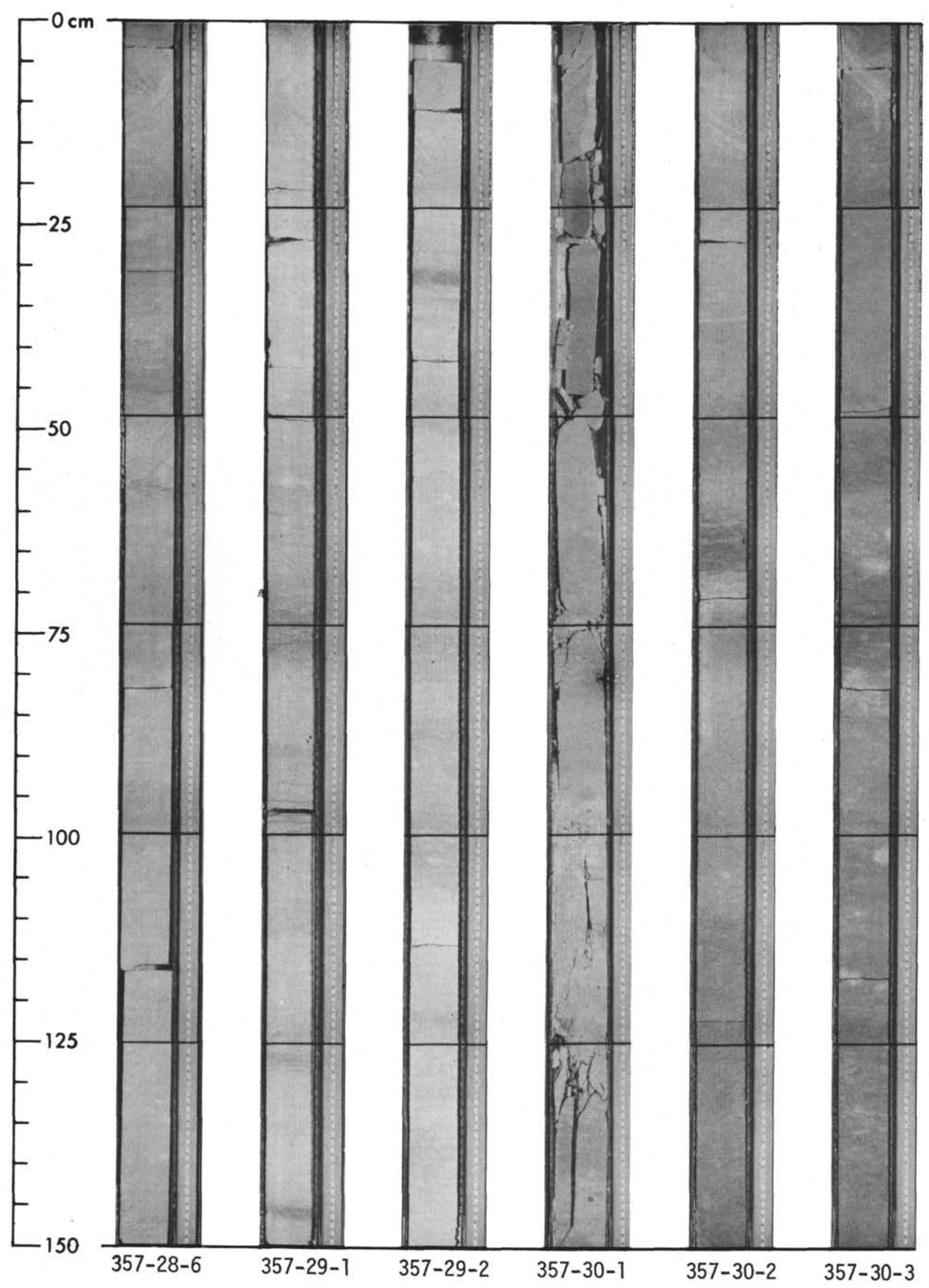


SITE 357: RIO GRANDE RISE

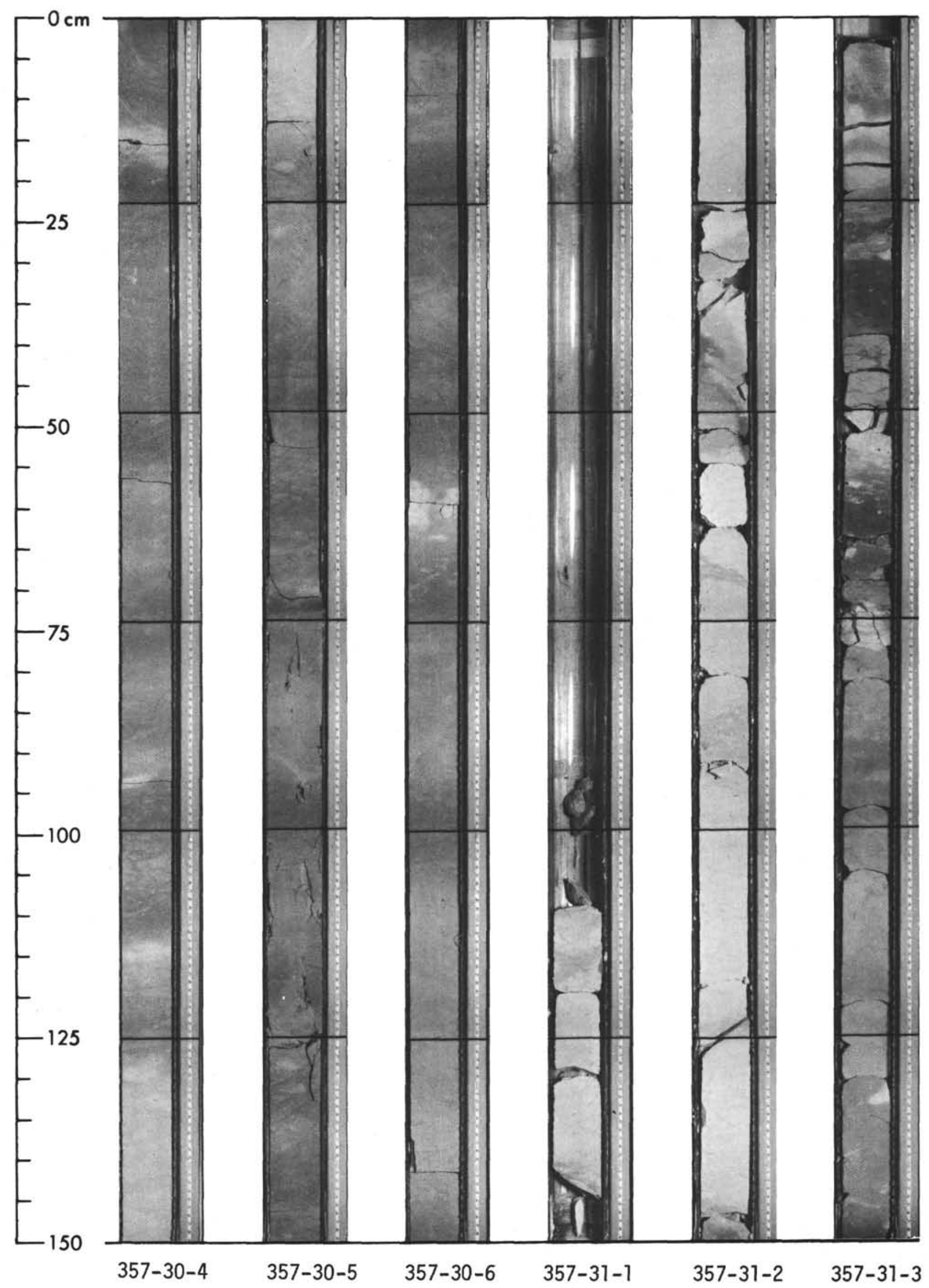




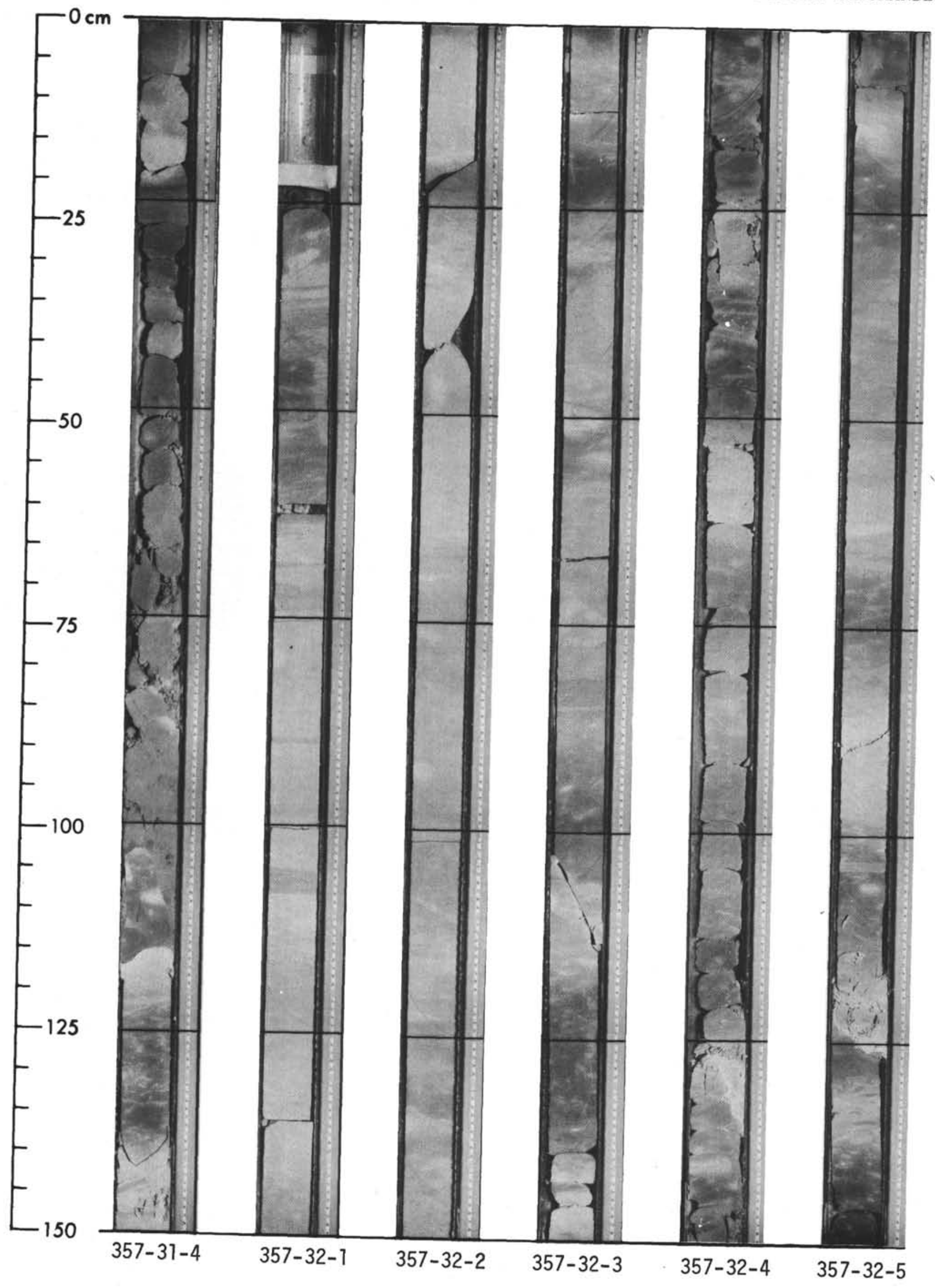


SITE 357: RIO GRANDE RISE

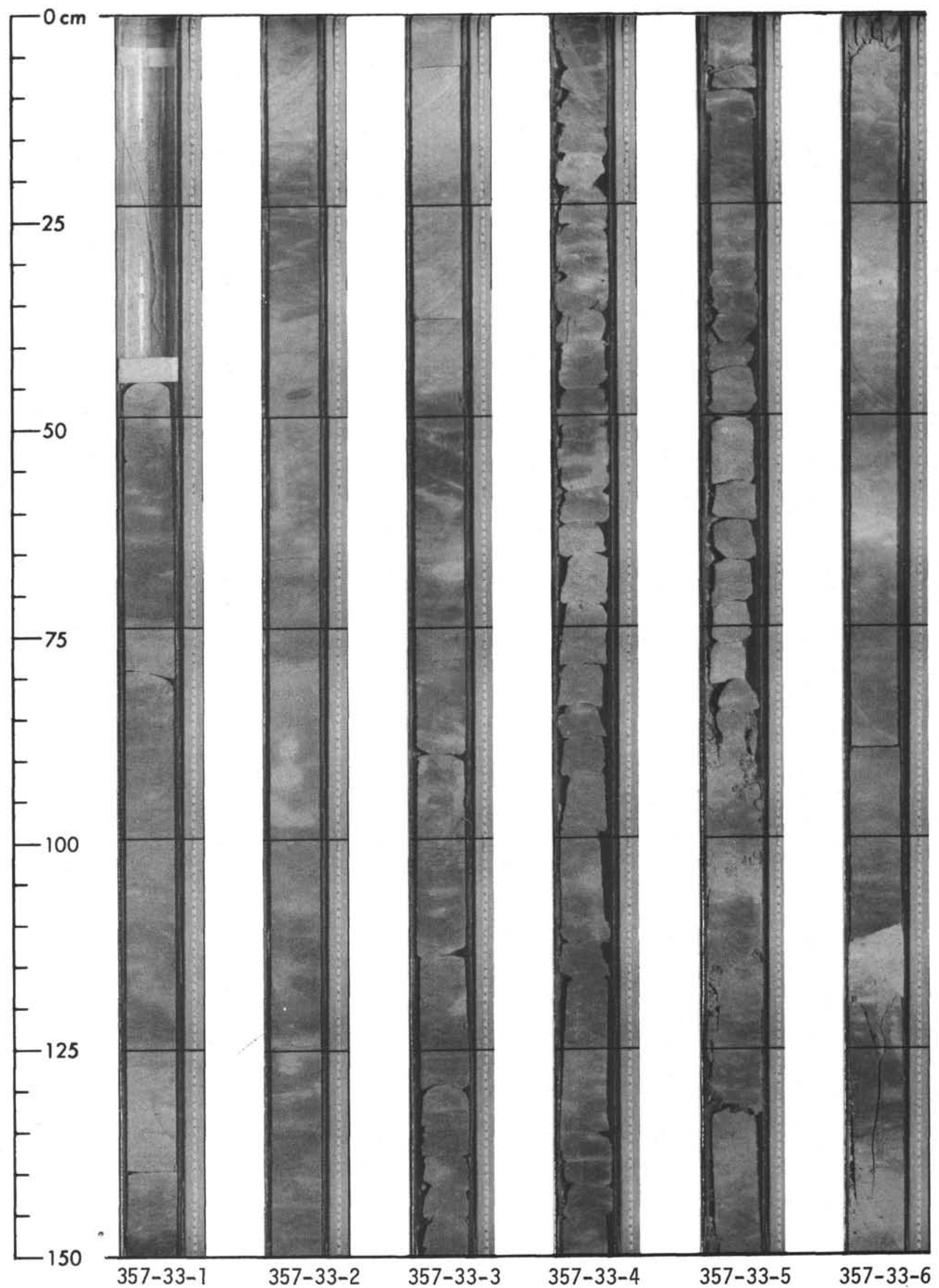


SITE 357: RIO GRANDE RISE

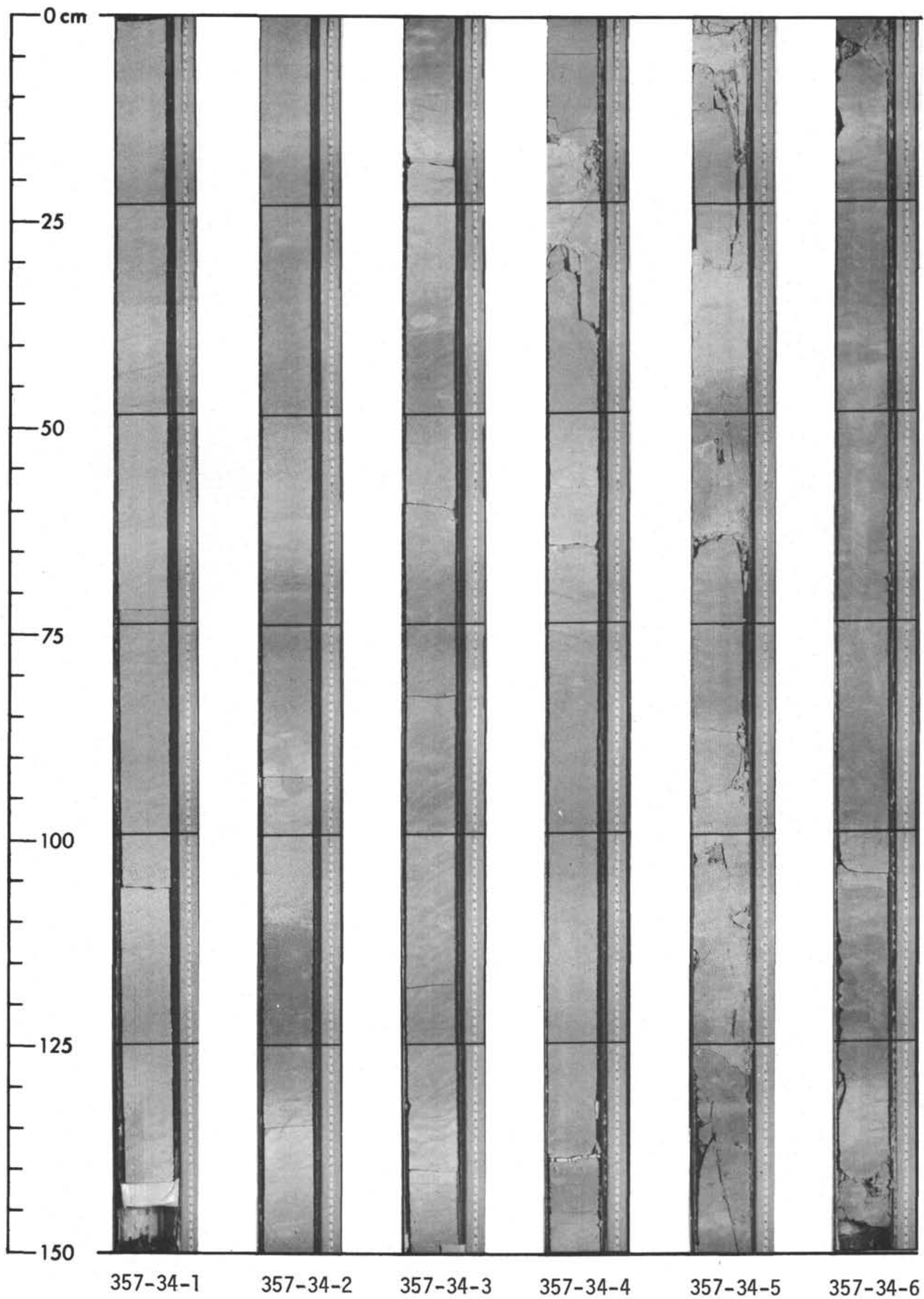




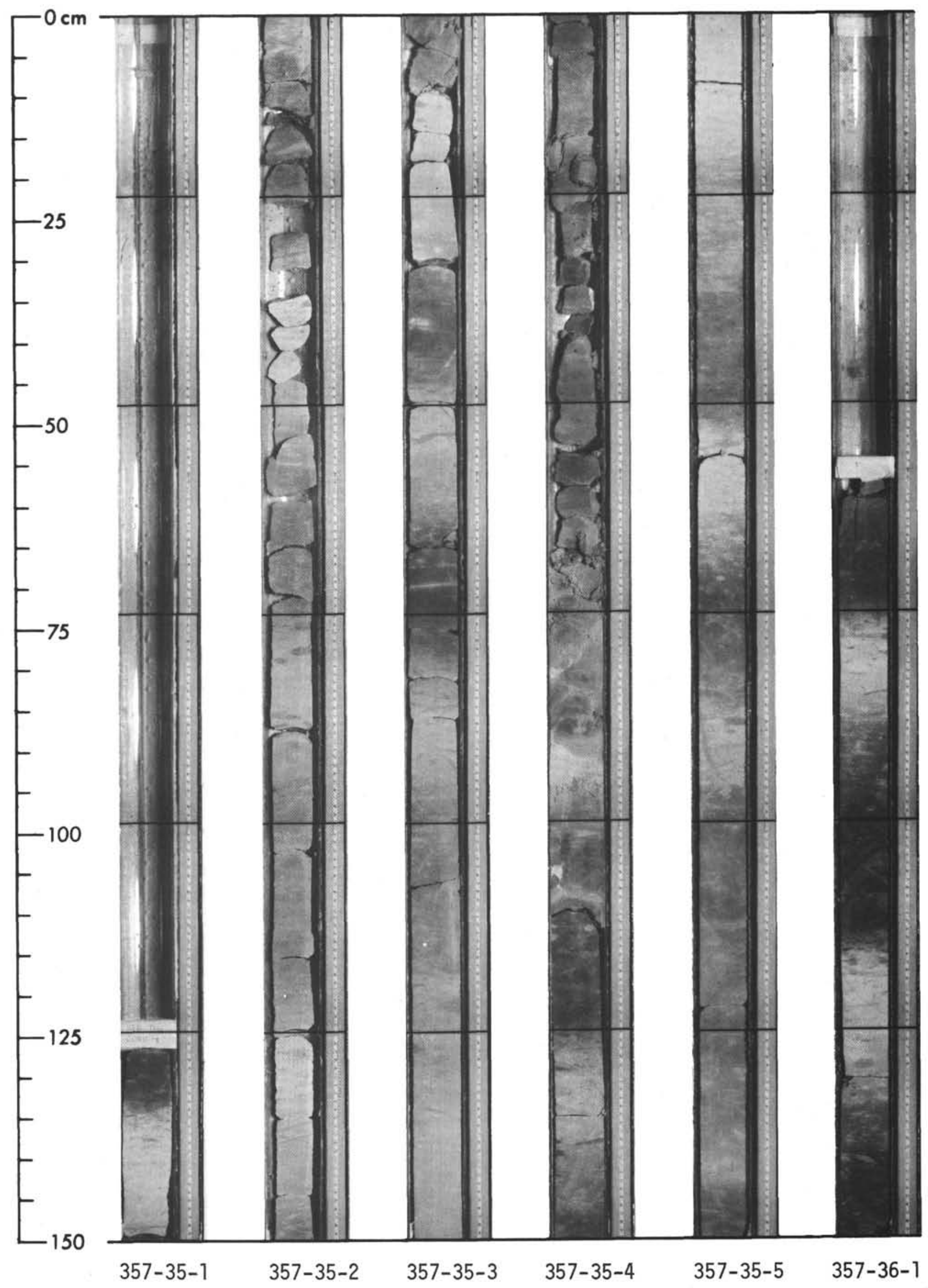


SITE 357: RIO GRANDE RISE

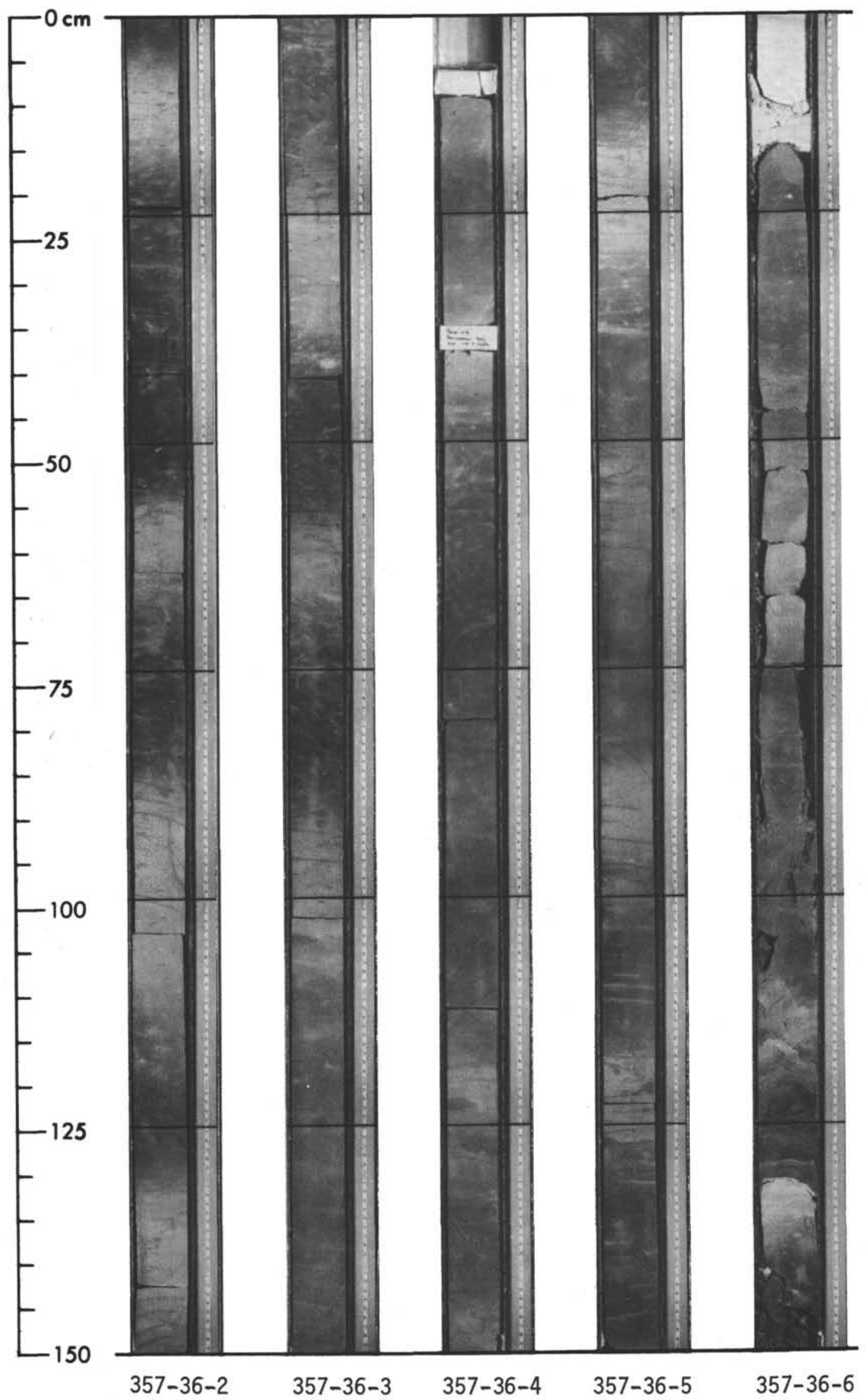




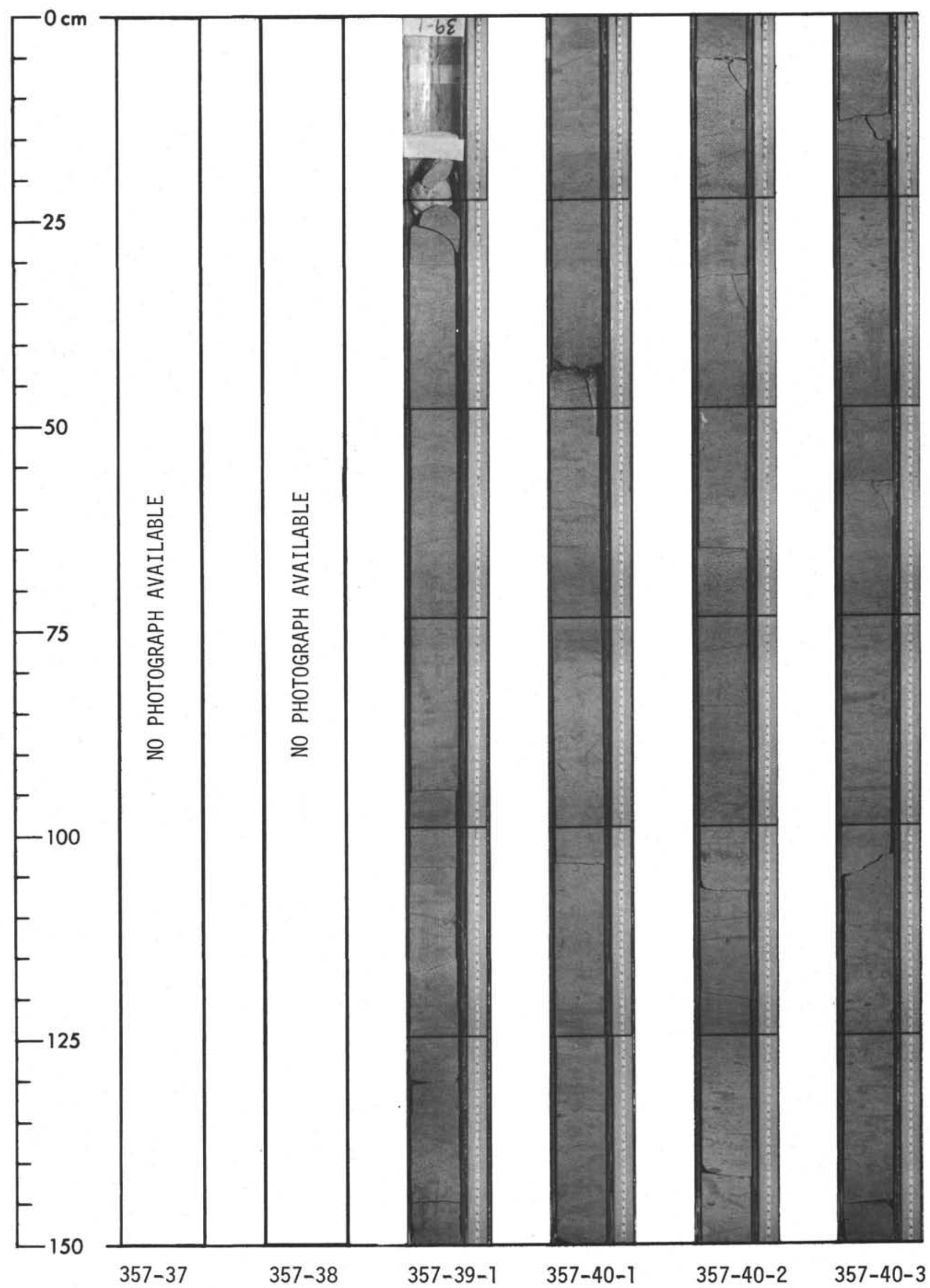




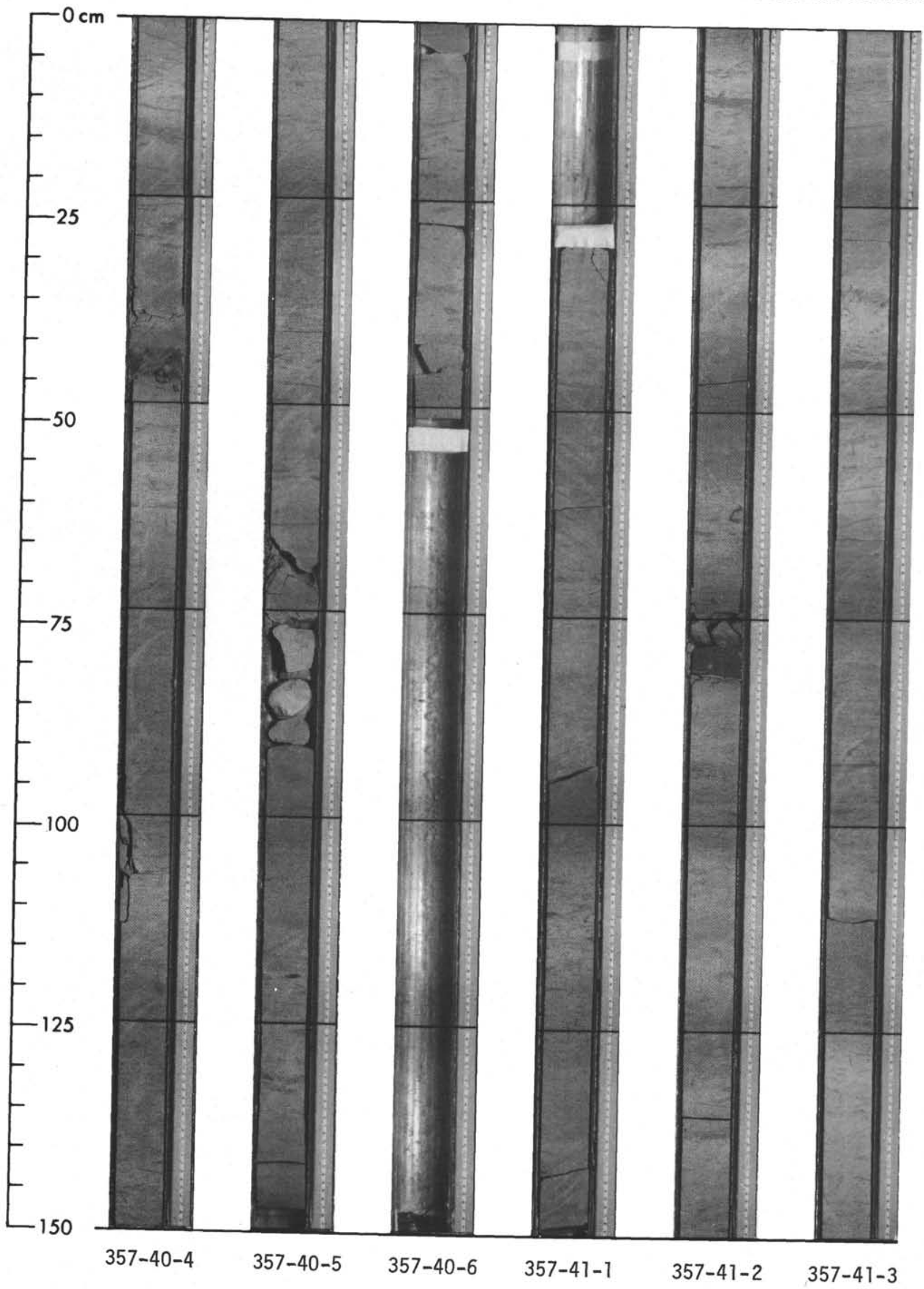




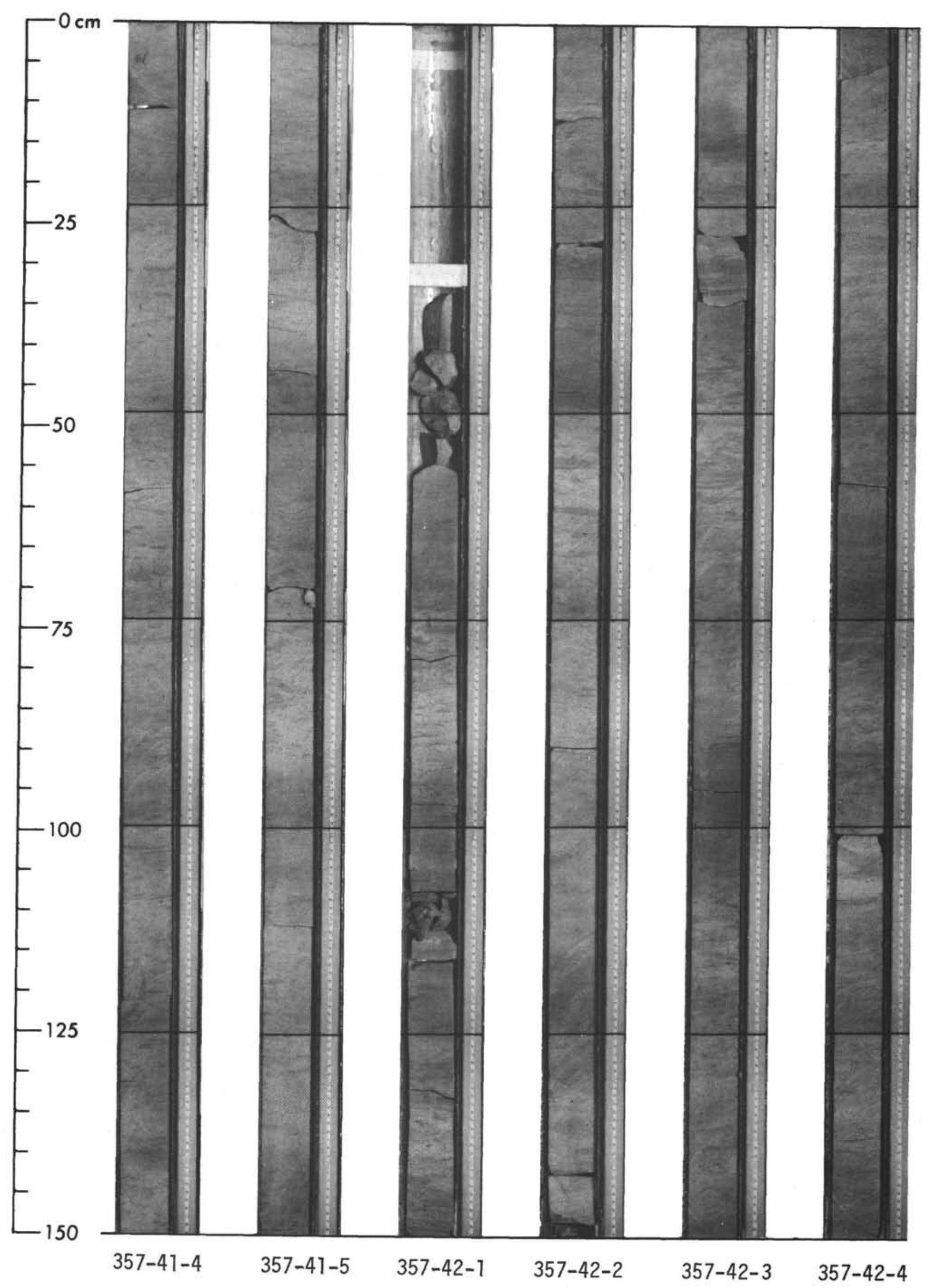




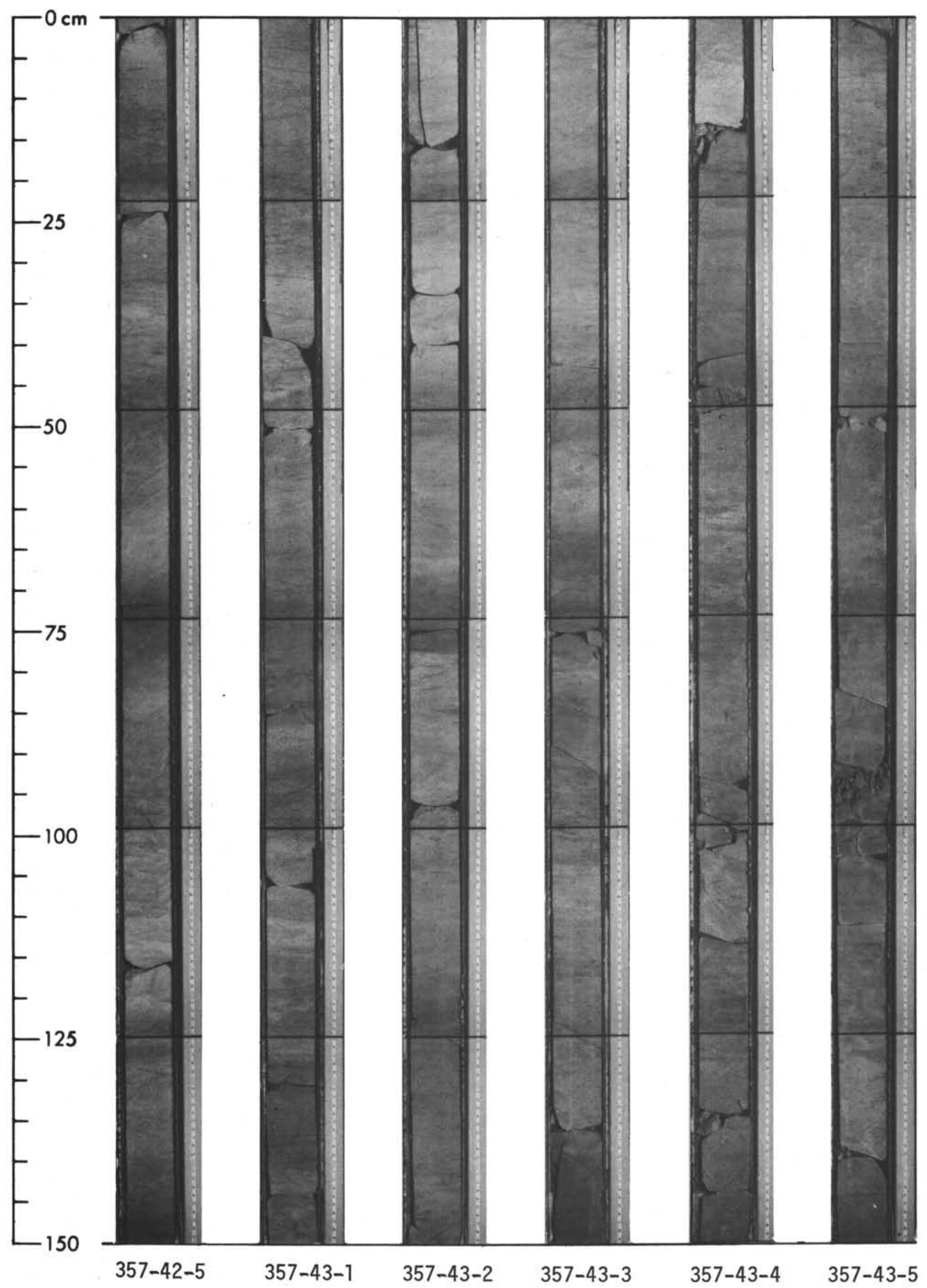


SITE 357: RIO GRANDE RISE

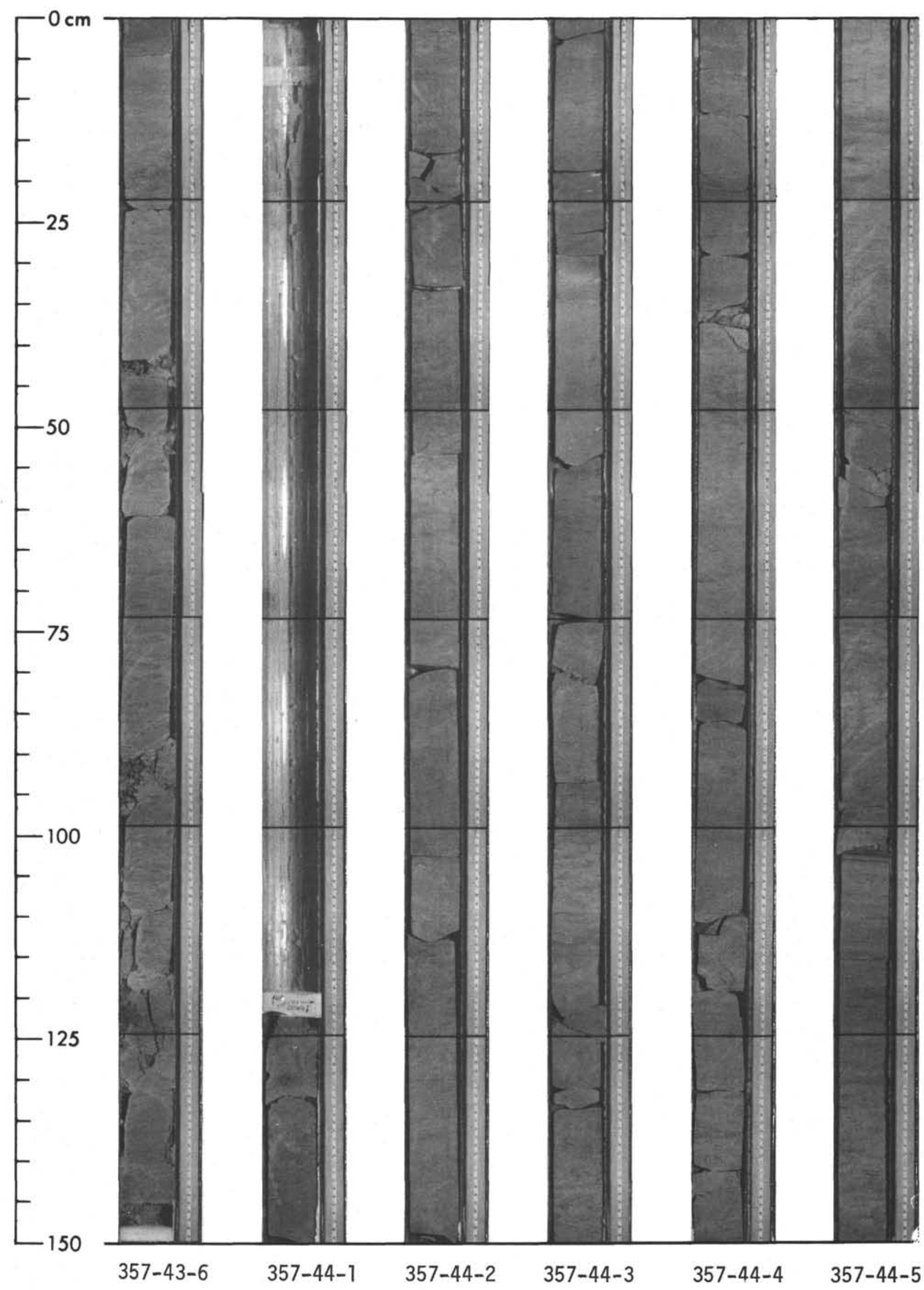




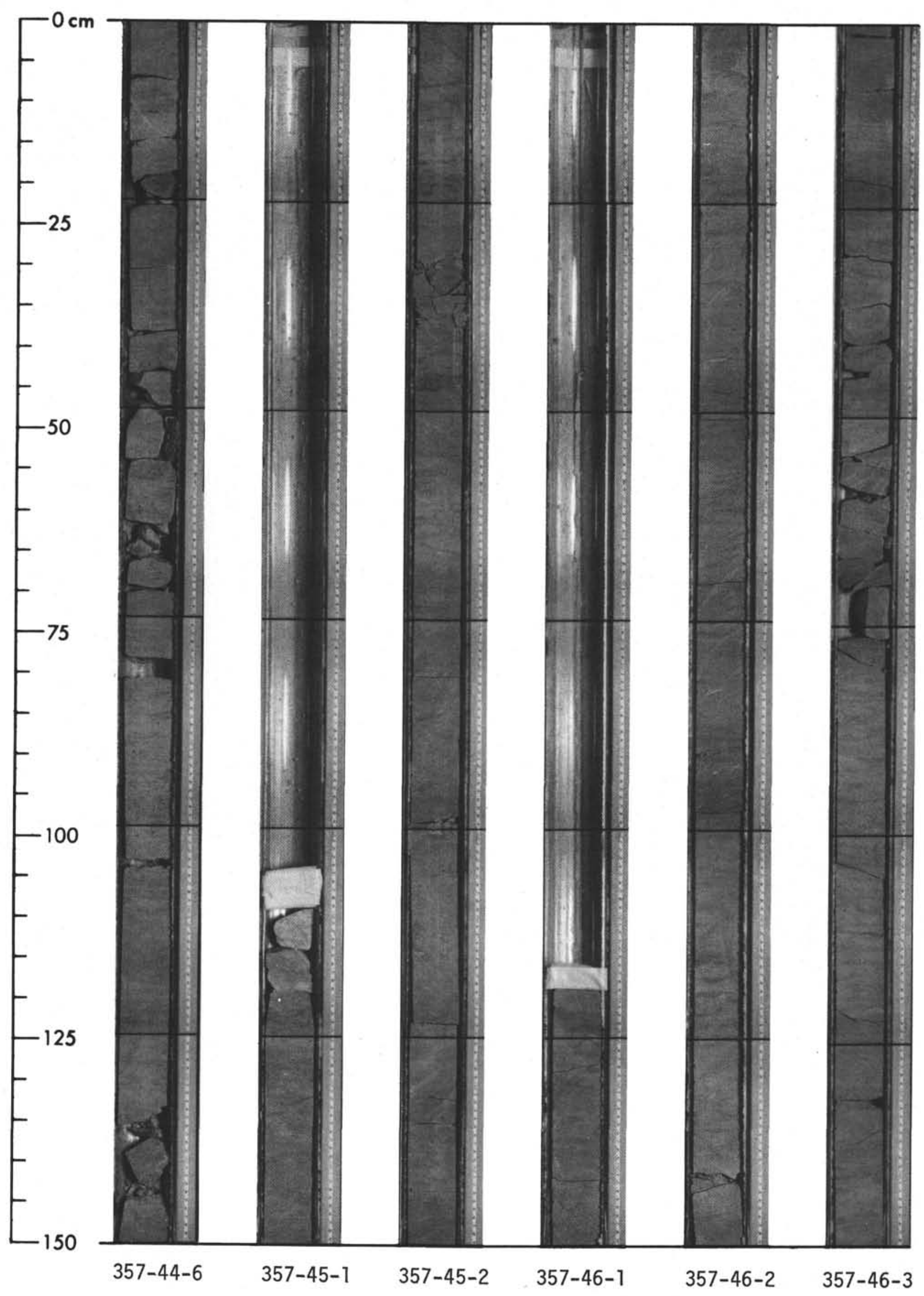


SITE 357: RIO GRANDE RISE

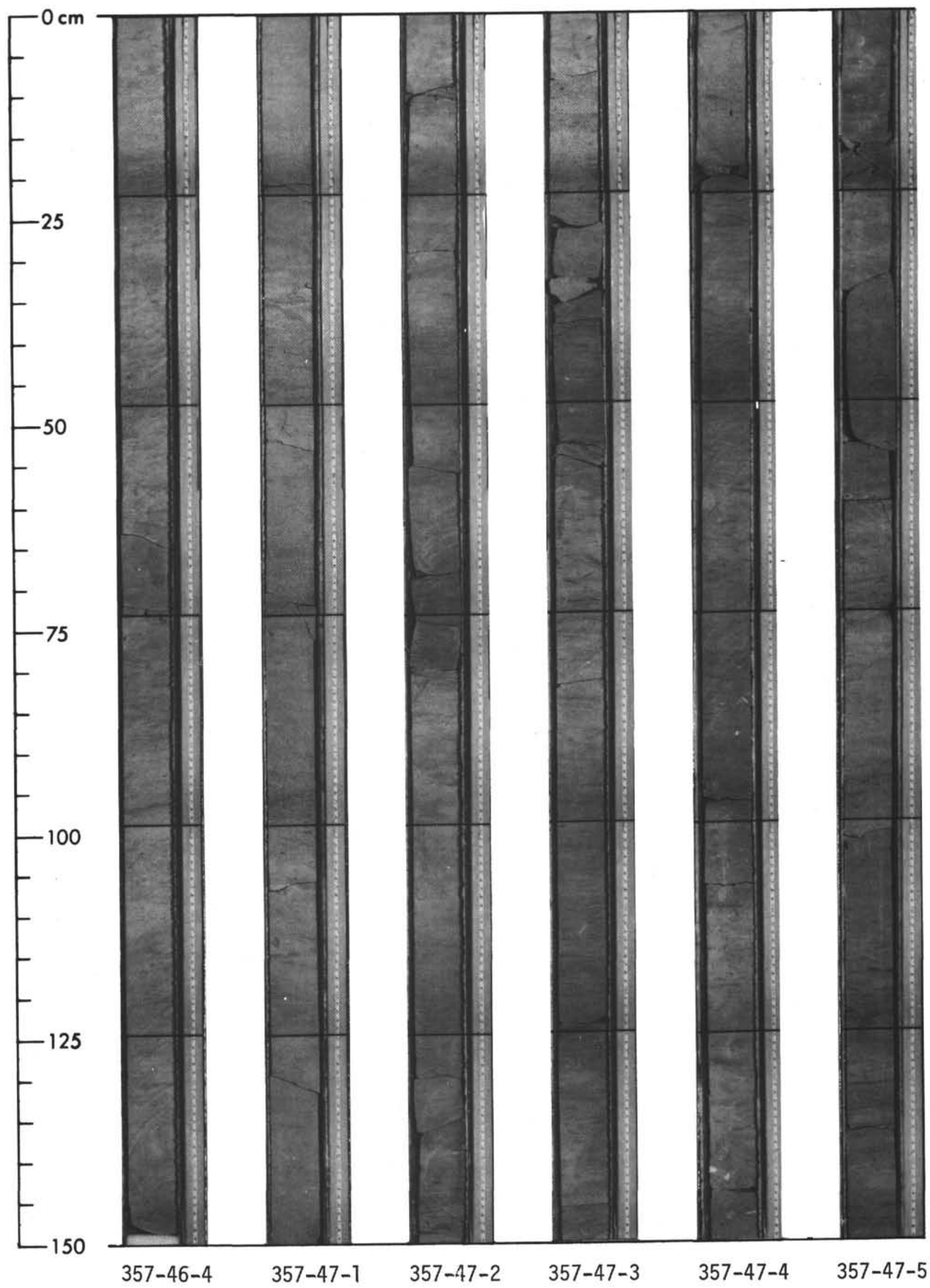




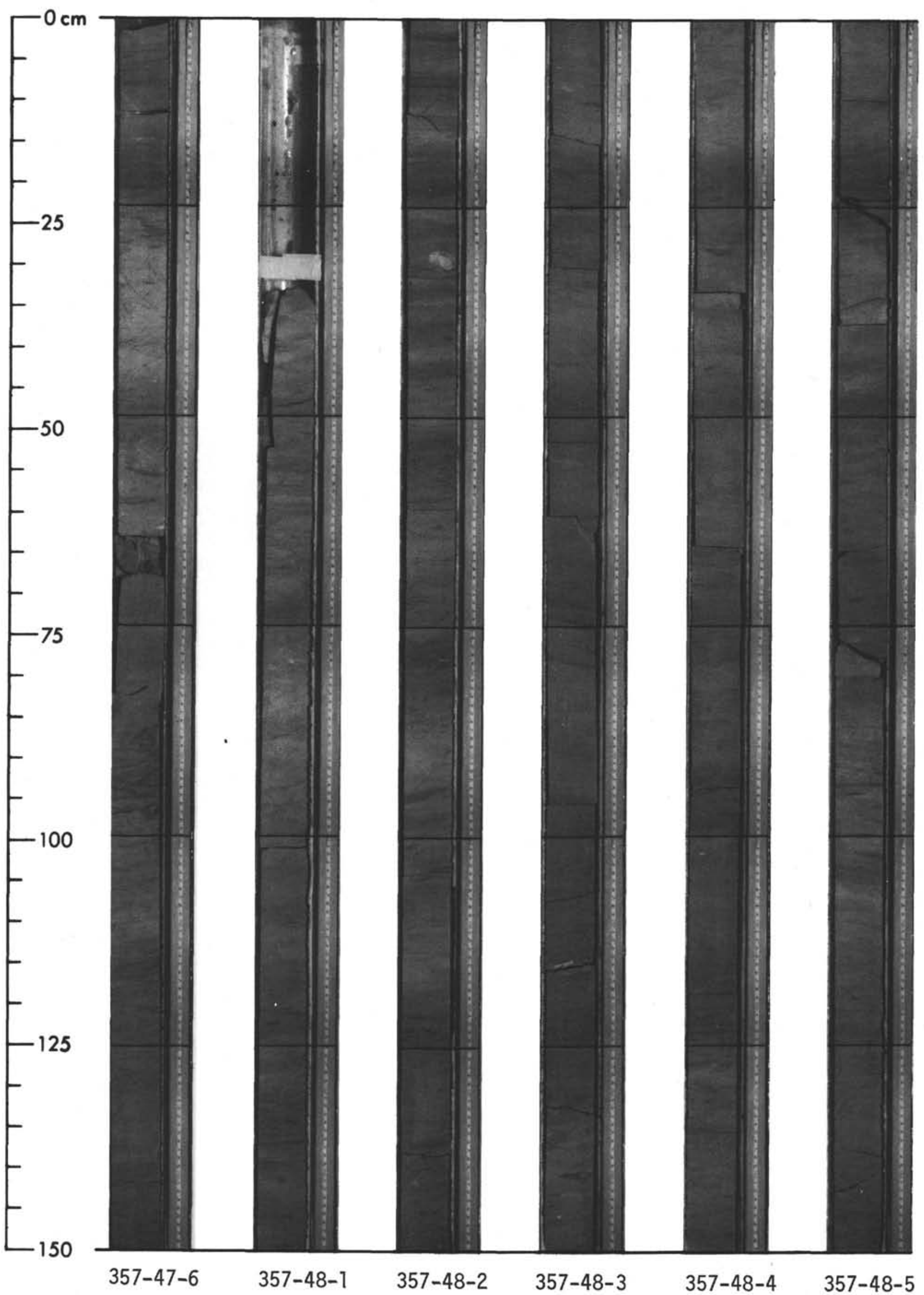




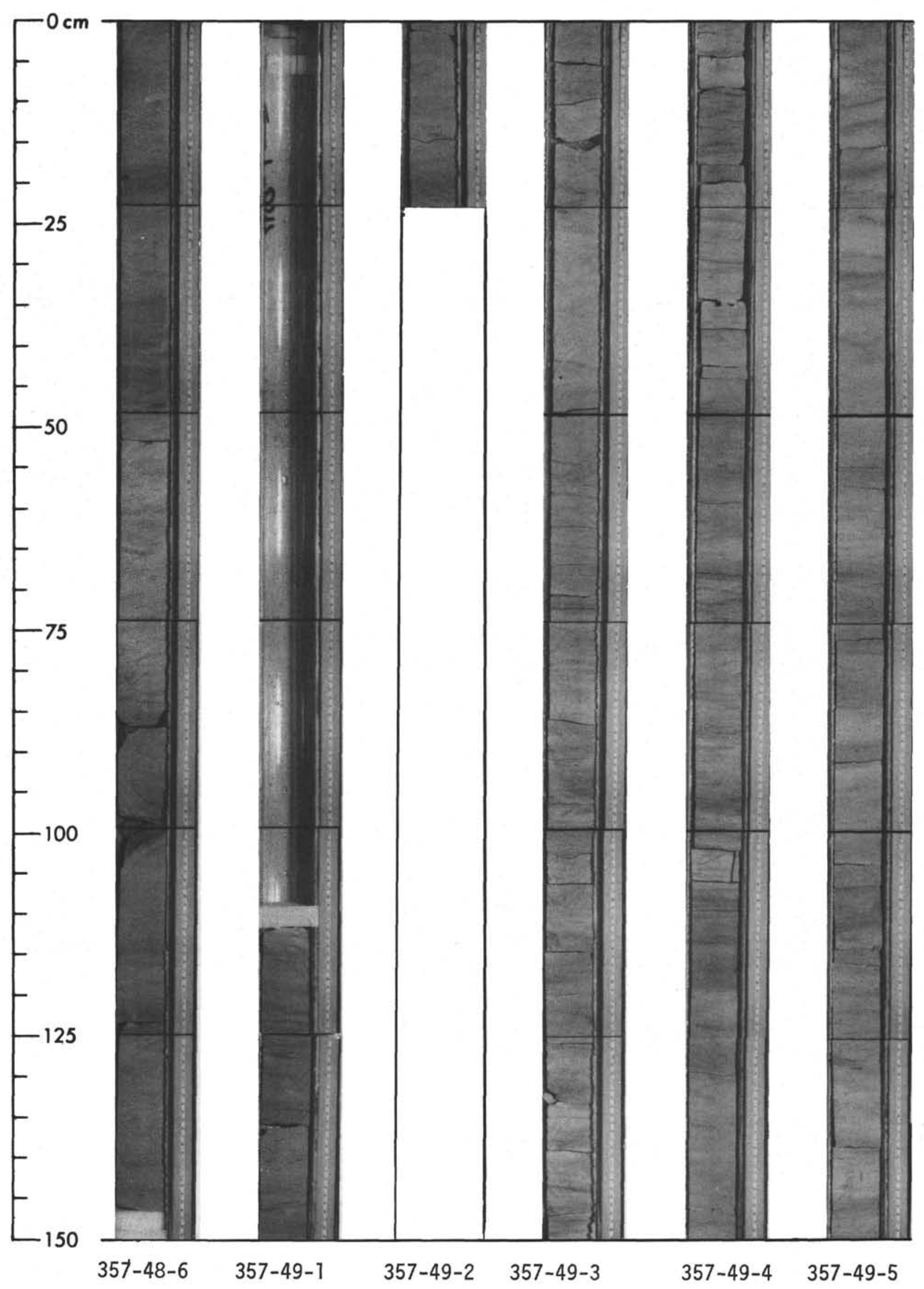


SITE 357: RIO GRANDE RISE

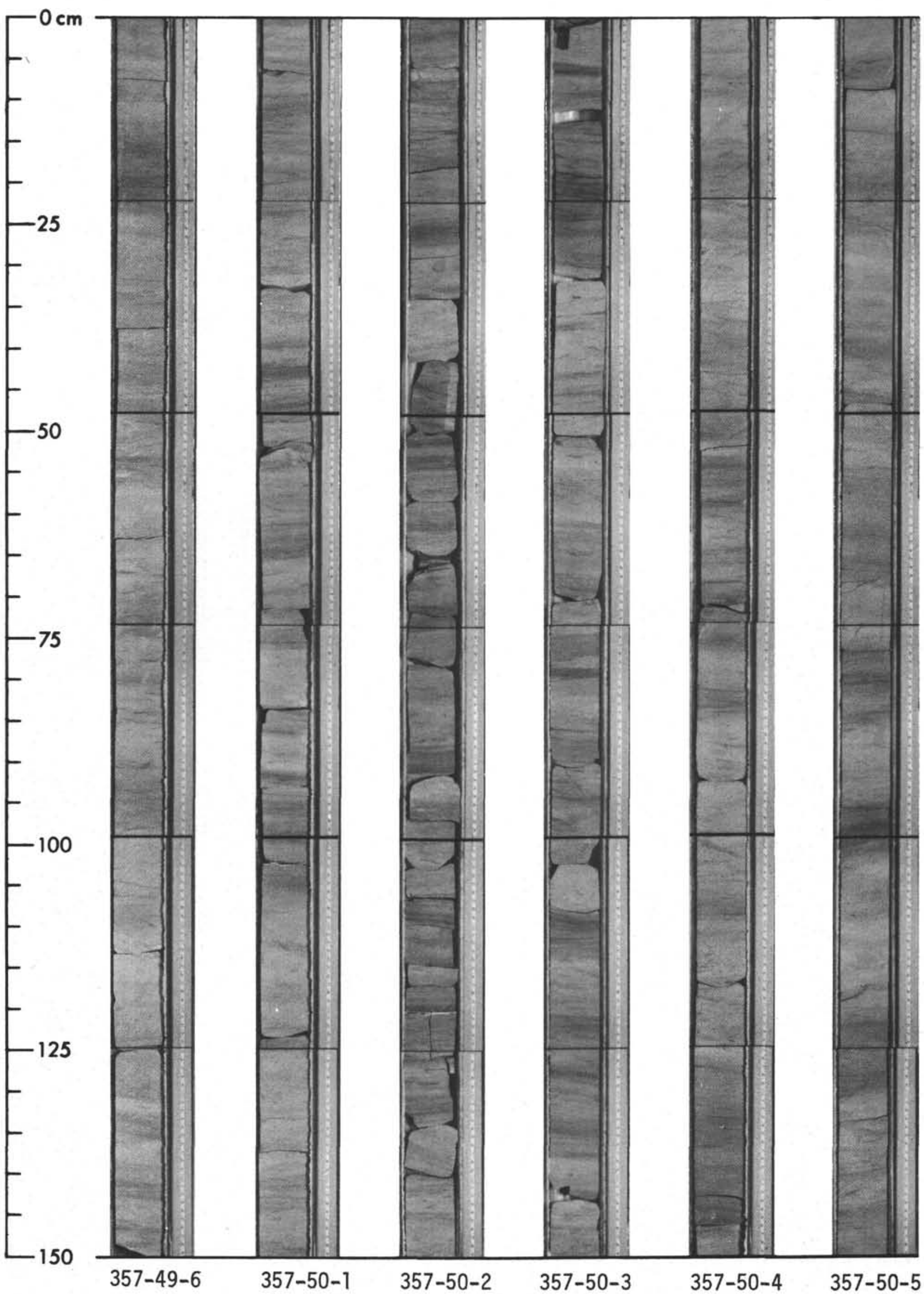


SITE 357: RIO GRANDE RISE

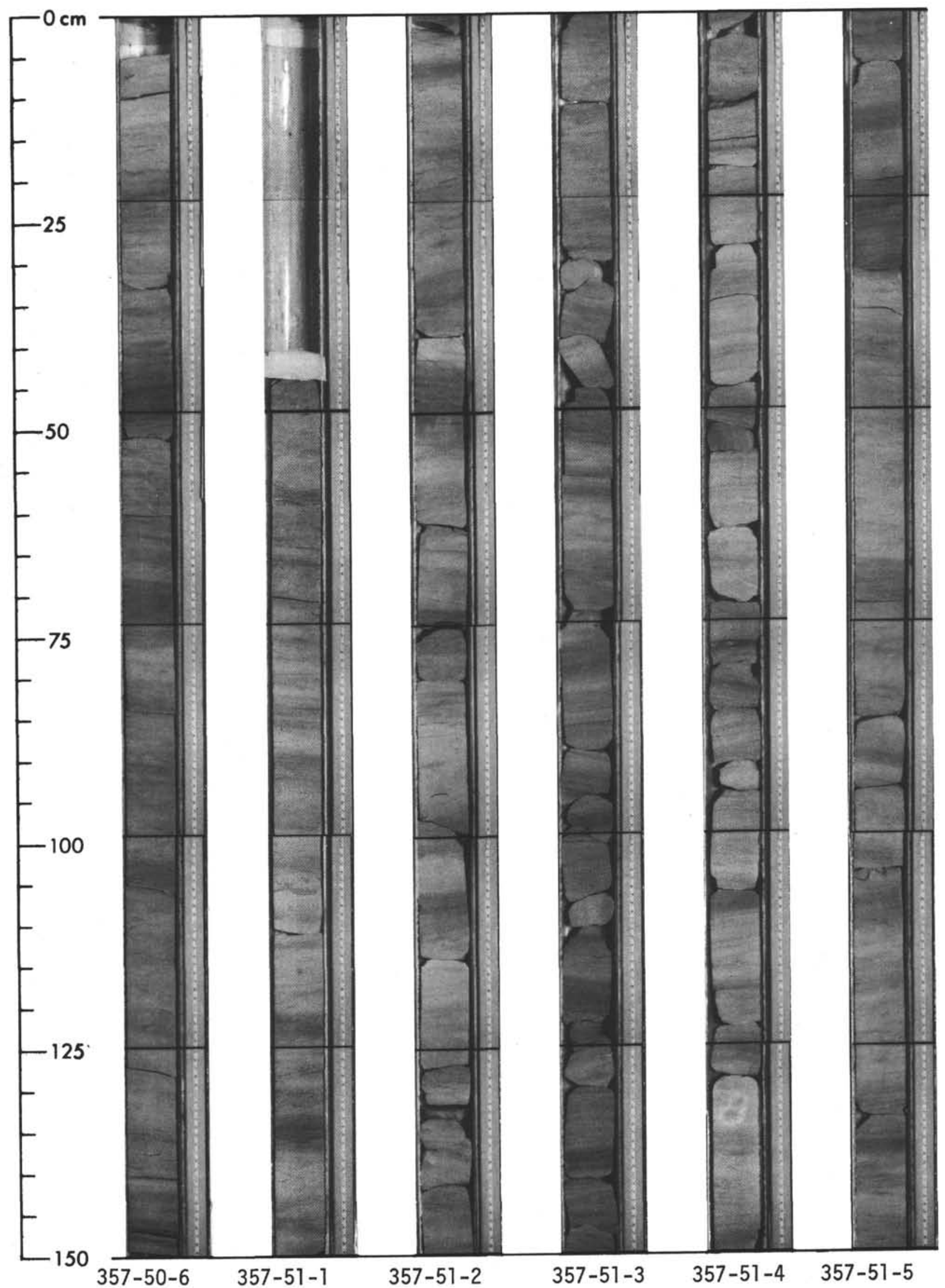




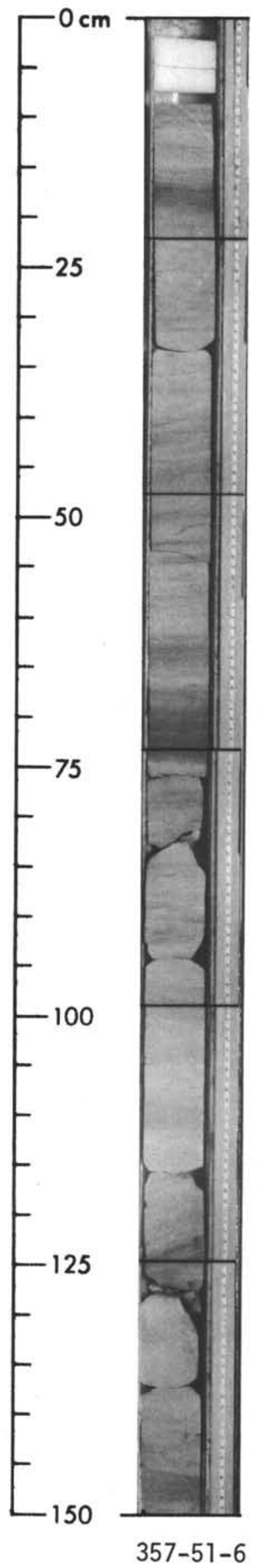

